
If you do not need this publication after it has served your purpose, please retura it to the
Geological Survey, using the offial mailing label at the end

UNITED STATES DEPARTMENT OF THE INTERIOR

ALKALIC ROCKS OF IRON HILL GUNNISON COUNTY, COLORADO

GEOLOGICAL SURVEY PROFESSIONAL PAPER 197-A 

UNITED STATES DEPARTMENT OF THE INTERIOR

Harold L. Ickes, Secretary

GEOLOGICAL SURVEY

w. C. Mendenhall, Director

Professional Paper 197-A

\title{
ALKALIC ROCKS OF IRON HILL GUNNISON COUNTY, COLORADO
}

BY

\author{
ESPER S. LARSEN
}

Shorter contributions to general geology, 1941

(Pages 1-64)

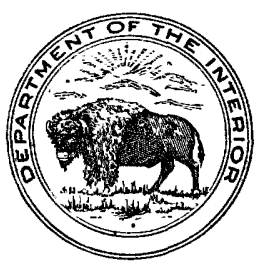

UNITED STATES

GOVERNMENT PRINTING OFFICE

WASHINGTON : 1942

For sale bỳ the Superintendent of Documents, Washington, D. C. - . $\ldots \ldots \ldots$ Price 40 cents 


\section{CONTENTS}

Preface, by G. F. Loughlin

\section{Abstract.}

Introduction.

Location and topography

Field work and acknowledgments................

Geology of the surrounding area..................

Age of the Iron Hill stock.........................

General geology of the Iron Hill stock

Hydrothermal activity . . . . . . . . . . . . . . . . . . .

Special features of the stock

"Marble" of Iron Hill

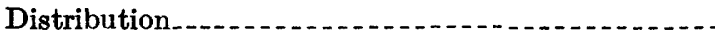

Character

"Marble",-......

Martite-apatite veins

Siliceous iron oxide veins. . . . .

Origin of the iron ore

Silicate rock

Carbonate bodies in the granitic rocks........

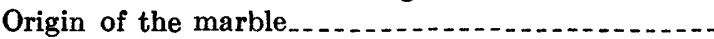

Available facts

Modes of origin

Uncompahgrite

Occurrence -

Fresh uncompahgrite

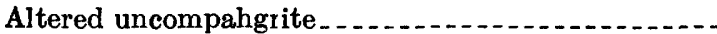

Chemistry of the alteration products.............

Chemical analyses, norms, and modes............

Pyroxenite.

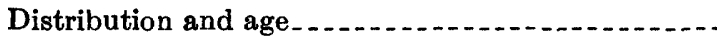

Character

General features.

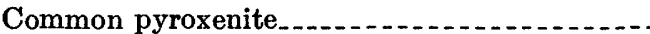

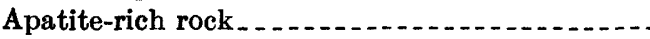

Biotite rock

Magnetite-perofskite rock

Olivine rock ............ . .

Garnet pyroxenite.

Nepheline pyroxenite (melteigite) ...........

Feldspar-nepheline rock (shonkinite) ...........

Feldspar-bearing rock . . .

Sphene pyroxenite.

Variations in the pyroxenite.........................

Order of crystallization and intrusion of the vari-

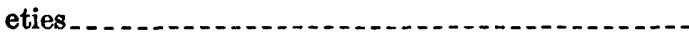

Origin of the varieties. . .

Chemical analyses, norms, and modes. ..........

Ijolite (melteigite)

Distribution

Petrography

Chemical analyses, norms, and modes.........

Crystallization of ijolite. . . . . . . . . .

Soda syenite. .............

Nepheline syenite.

Nepheline gabbro and quarta gabbro

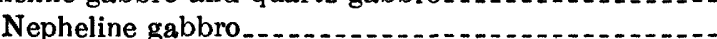

Quartz gabbro

Chemical analyses, norms, and modes
Page

Other dike rocks

Augite syenite and shonkinite

Olivine gabbro ................ 30

Carbonate veins

Character............ 31

Origin

Hydrothermal processes . .

The hydrothermal products.

Carbonate type........................... 32

Apatite-magnetite-carbonate veins and iron oxide

veins.

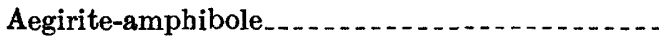

Hastingsite and diopside

Melanite...........................

Alterations of melilite

Zeolites, cancrinite, and analcime.............

Other types

Conclusions

(n)

Comparison with other areas.

General character of the stock

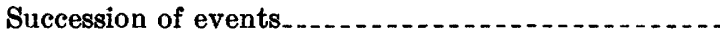

Relative size of formations..........

Mineral character of the stock

Chemistry of the stock

Petrogenesis

Comparison with similar masses......... 36

Rocks_.................. 38

Minerg $\operatorname{logy} \ldots$

Chemical character.

Succession of intrusions.................. 39

Origin of the rocks .

Uncompahgrite........................ 40

Pyroxenite....... 40

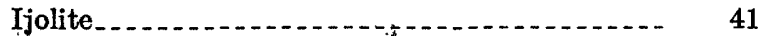

Syenite and nepheline syenite $\ldots . . . . . . . . . .41$

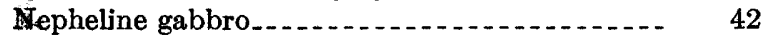

Quartz gabbro

Conclusions as to origin . . . . . . .

Mineralogy, by E. S. Larsen and W. F. Jenks...... 43

Sulfides_........... 43

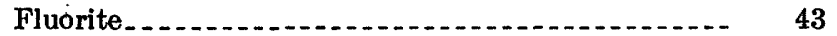

Quartz . .

Spinel . . . . .

Oxides of titanium

Iron oxides_................ 43

Carbonates...

Brugnatellite......... 44

Feldspar........... 44

Lime-soda feldspar....

Albite, microcline, and orthoclase ........... $\quad 44$

Nepheline................... 44

Melilite

Pyroxenes ... . . .

Amphiboles . ........ 48

Soda-tremolite and glaucophane group...... 50

Hastingsite group.... 52

Wollastonite...... 52 
Mineralogy, by E. S. Larsen and W. F. Jenks-Continued.

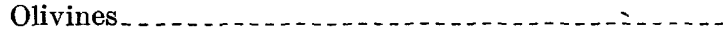

Micas .

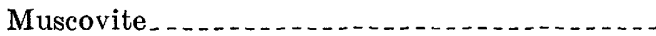
Biotite and phlogopite

Apatite

Sphene

Perofskite

Idocrase $\ldots$

Melanite

Chlorites, serpentine, and vermiculites............

Cancrinite and sulfatic cancrinite

Natrolite
Page

52

53

53

53

53

53

54

54

54

54

54

55
Mineralogy, by E. S. Larsen and W. F. Jenks-Continuef.

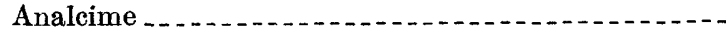
Juanite and cebollite

Titanium

Phosphorus

Manganese

Barium and strontium ........................ Zirconium, nickel, chromium, and vanadium ......

Chlorine and fluorine...........................

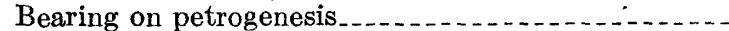
Spectroscopic tests.

Pagè

55

56

56

57

58

58

59

60

Index $\ldots \ldots$...

\section{ILLUSTRATIONS}

Pute 1. Geologic map of Iron Hill area, Gunnison County, Colo

2. Panorama of the Iron Hill area

3. $A, B$, Pyroxenite on south side of Stone Gulch; $C$, Banded syenite.

FIgURE 1. Marble-pyroxenite contact _...

2. Section scuth of Stone Gulch, showing variation in pyroxenite

3. Section on north side of Stone Gulch, showing variation in pyroxenite.

4. Section south of Deldorado Creek, showing variation in pyroxenite

5. Section northeast of gully B, showing complex relations of uncompahgrite and varieties of pyroxenite $\ldots$

6. Pseudo-binary diagram of equilibrium in mixtures of nepheline and diopside

7. Optical properties of the pyroxenes carrying acmite plotted against content of $\mathrm{Fe}_{2} \mathrm{O}_{3}$ and acmite $\ldots$

8. Soda tremolite and glaucophane amphiboles, atomic ratios plotted against $\mathrm{Mg}+\mathrm{Fe}^{\prime \prime}-\mathrm{Al}-\mathrm{Fe}^{\prime \prime \prime} \ldots \ldots$

9. Soda tremolite and glaucophane amphiboles, $\beta, \mathrm{Y} \wedge \mathrm{c}$, and specific gravity plotted against $\mathrm{Mg}+\mathrm{Fe} \mathrm{e}^{\prime \prime}-\mathrm{Al}-\mathrm{Fe} \mathrm{e}^{\prime \prime}$-..- 51 


\section{PREFACE}

By G. F. Loughlin

The author of this paper gives a thorough description of a complex of very unusual igneous rocks and associated hydrothermal deposits. Their unusual character involves difficulties in interpretation of genesis and modes of intrusion and deposition, and even in definition. Perhaps the most puzzling deposit of all is the central mass of dolomite, which the author aptly terms "marble," a term that applies mainly to different metamorphosed and unmetamorphosed carbonate rocks. The author, however, suggests a hydrothermal or even intrusive origin, as this suggestion, based on negative evidence, meets fewer objections than any other.

As may be expected, some of those who have read the manuscript of this report critically are skeptical regarding certain of the author's interpretations, but the assemblage of rocks is so unusual and the interpretation involves so much speculation that "doctors may be expected to disagree" in the light of their different experiences. Such differences of opinion reflect the healthy growth of the science of petrology and help to guide future investigations. The description of this unusual complex and the author's interpretation of its oricin, therefore, should be most interesting, especially to those studying the origin of igneous rocks. Obviously, the author, after such detailed field work, has the advantrge over all others in the drawing of conclusions, and it is interesting to note that he is inclined to be more conservative than some of his critics and places more emphasis on the field evidence of complex processes than on the data supplied from relatively simple processes in the laboratory. Continued progress in the physical chemistry of igneous intrusive rocks and of hydrothermal processes will gradually shed new licht on the problems involved, and the text and geoloric map in this report will always afford a sound basis for confirmation or inodification of the author's conclusicns in the light of continuous progress. 


\title{
SHORTER CONTRIBUTIONS TO GENERAL GEOLOGY, 194:1
}

\author{
ALKALIC ROCKS OF IRON HILL, GUNNISON COUNTY, COLORADO
}

\author{
By ESPER S. LARSEN
}

\begin{abstract}
The Iron Hill stock is in southwestern Colorado, in Gunnison County, about 20 miles south of the village of Iola. It intrudes into pre-Cambrian granites and is overlain by late Jurassic sandstones. It underlies an area of about 12 square miles. The oldest rock in the stock is a uniform dolomitic mass, conveniently called "marble," which forms an isolated hill 1,000 feet high and over a mile across, as well as several small inclusions in the igneous rocks of the stock. Small bodies of similar marble are found as hydrothermal deposits in the surrounding pre-Cambrian rocks. The main mass of marble is also believed to be a large hydrothermal deposit formed in the throat of a volcano, though it may have been intruded as a carbonate magma or it may be an inclusion of pre-Cambrian marble.

The oldest igneous rock of the stock is a coarse- to giantgrained melilite rock that has been called "uncompahgrite." The next intrusion was a pyroxenite, which underlies about 70 percent of the area of the stock. It varies greatly in texture and in the proportions of the minerals present, ranging from a nearly pure diopside rock to a biotitite, a perofskite-magnetite rock, an apatite-perofskite rock, local feldspar, nepheline, and titanite varieties, and rare dikes of an olivine rock. The variation is erratic, and a small outcrop may show many varieties. The contacts of the varieties are commonly sharp, and the finegrained varieties commonly cut those of coarse grain, the micarich varieties cut those poor in mica, and those rich in apatite cut the others, except the perofskite-magnetite rock, which is commonly last.

The pyroxenite was cut by a coarse nepheline-pyroxenegarnet rock (ijolite), which varies erratically in the relative proportions of pyroxene and melanite garnet. In places this rock intimately injects the pyroxenite and the nepheline has soaked into the pyroxenite.

The next intrusion was a soda syenite. This rock is commonly banded and in places has a gneissoid structure, developed during intrusion. It tends to occur along or near the border of the stock and some of its contacts with the pre-Cambrian rocks show evidence of faulting, which probably took place mostly during the last stages of crystallization of the syenite. A nepheline syenite followed the syenite and also tends to occur along the borders of the stock.

The last intrusions of the stock are represented by a series of subparallel dikes of nepheline gabbro and quartz gabbro, a few of which contain both rocks.

Hydrothermal solutions were active throughout the history of the stock. In the uncompahgrite, melanite was deposited in the late stage of the pyrogenic crystallization, and a garnet poor in iron and titanium continued to form in the early hydrothermal stage (after the solutions had begun to move along fractures). Later, idocrase and diopside were formed, first in asso-
\end{abstract}

ciation with garnet and then alone. At a still later time the melilite was locally replaced by cebollite and then by juanite.

The most widespread hydrothermal products are aegirite and a soda amphibole with or without phlogopite and other miners.ls. These three are also the chief minerals introduced into the dolomite during its hydrothermal metamorphism by the pyroxenite. Aegirite and amphibole are also abundant in the hydrothermal carbonate bodies that cut the pre-Cambrian rocks, and they are present in numerous seams in all the rocks of the area, including the pre-Cambrian. A magnesic hastingsite is a common replecement product of the pyroxenes and was found in one carbon?te vein.

Numerous veins of granular dolomite, containing some quartz, alkalic feldspar, sulfides, fluorite, and some silicates, cut the rocks of the stock. Veins of dolomite and calcite, apatite, quartz, alkalic feldspar, and martite cut the marble.

The Iron Hill stock is much like those of Fen, Norway; Magnet Cove, Ark.; Jacupiranga, Brazil; and Libby, Mont. The peculiar rocks of the stock are believed to have been formed by reaction of a basaltic magma on marble, followed by crystal differentiation.

Analyses of many rocks and minerals are given. The amphiboles between soda tremolite and glaucophane are discuss?d, and curves for the variation of the optical properties with $\mathrm{ccm}$ position of this group and of the diopside-acmite pyroxenes are given. The minerals of the area are described in some detail.

A section on the rare constituents of the rocks and minerals of the stock concludes the report.

\section{INTRODUCTION LOCATION AND TOPOGRAPHY}

The small stock of alkalic rocks described in this report lies in southwestern Colorado, on the northern flank of the San Juan Mountains, south of the Gunnison River, about 20 miles south of the village of Iola and 22 miles approximately $\mathrm{S} .15^{\circ} \mathrm{W}$. from the town of Gunnison. It is in the southern part of Gunnison County, a few miles east of Powderhorn post offise. It is near the middle of the eastern border of Uncompahgre quadrangle, is just east of Powderhorn. Valley of Cebolla Creek. It includes the lower drain $\varepsilon$ re basins of Beaver and Deldorado Creeks and of some smaller gulches to the north of these creeks.

It is best reached from Iola, from which there is a good mountain automobile road. Poor roads, passable by an automobile, go up both forks of Beaver Creek, up 
SHORTER CONTRIBUTIONS TO GENERAL GEOLOGY, 1941

Deldorado Creek, and up some of the other gulches, so that an automobile can be taken within a few miles of any part of the area.

The chief igneous rocks of the stock weather readily to a friable sand but the marble mass near the center of the stock and the surrounding granitic rocks are rather resistant. The marble therefore forms a steep, rocky hill, Iron Hill, which rises about 1,000 feet above the valley; the igneous rocks of the stock form a ring of rather low rolling hills about Iron Hill; and the older granitic rocks form steep, rocky hills about the stock. Locally, mesa-forming flows of lava overlie the stock. Plate 2 is a panorama of the area taken from the slopes between the forks of Beaver Creek, between gullies $\mathrm{H}$ and $I$ and 100 feet below the knoll of ijolite shown in plate 1. The rounded hill left of the center is Iron Hill, made up of marble. The gentle slopes surrounding Iron Hill are underlain by the pyroxenite and other rocks of the Iron Hill stock, and the steeper slopes surrounding the Iron Hill basin consist of pre-Cambrian rocks overlain by sandstone of the Morrison formation on the right. The hill on the extreme left is Rudolph Hill, those in the background to the left of Iron Hill are pre-Cambrian hills west of Powderhorn Valley, and those to the right of Iron Hill are made up of the pre-Cambrian rocks capped by the Morrison formation, at the heads of Huntsman Gulch and Deldorado Creek.

\section{FIELD WORK AND ACKNOWLEDGMENTS}

The field work on the area was done chiefly in the summers of 1912 and 1913, as a part of the mapping of the Uncompahgre quadrangle, under the direction of Whitman Cross. Brief visits to the area were made in later years, the last in 1930. J. Fred Hunter assisted in some of the field work, and E. W. Goranson and William F. Jenks assisted in some of the laboratory work. J. W. Greig, of the Geophysical Laboratory, visited the area with the author in the summer of 1930 and offered many helpful suggestions.

Most of the field work and part of the office work was done under the auspices of the United States Geological Survey, and a part of the field work and much of the office work was done at Harvard University. In the section on mineralogy William F. Jenks, of Harvard University, is joint author, and in that on minor constituents George Steiger, of the Geological Survey, is joint author.

\section{GEOLOGY OF THE SURROUNDING AREA}

In this part of the San Juan Mountains the preCambrian rocks are chiefly gneisses, schists, and amphibolites intruded by various granitic rocks. They have been mapped and described by Hunter ${ }^{1}$. Adjoining the Iron Hill stock the pre-Cambrian rocks are chiefly

1 Hunter, J. F., Pre-Cambrian rocks of Gumnison River, Colo.: U. S. Geol. Survey Bull. 777, 1925, gray biotite granite, porphyritic granite, and granite porphyry. These old rocks were eroded to a poneplain, and a thick series of Paleozoic sediments, including considerable limestone, was laid down on the peneplaned surface and was in turn covered by Triassic sediments.

Peneplanation again took place, and the Paleozoic rocks were removed from the area near Iron Hill. They are exposed today within 40 miles to the west, north, and east of Iron Hill and probably once covered the Iron Hill area. Late Jurassic sandstones and shales of terrestrial origin, represented by the Morrison formation, were laid down on the peneplain and were covered by a thick series of Cretaceous beds. After renewed erosion, volcanic flows and tuffs of the Potcsi series were laid down in Miocene time on an irregular surface. In the immediate vicinity of Iron Hill (pl. 1) the rocks are chiefly pre-Cambrian, but nearly horizental Morrison beds cap Huntsman's Mesa, which borders the Iron Hill basin on the northeast, and remnants of the Potosi volcanic rocks, mostly rhyolites and quartz latites, immediately overlie the Iron Hill rocks and form small mesas within the Iron Hill basin.

\section{AGE OF THE IRON HILL STOCK}

The Iron Hill stock clearly intrudes into the latest of the pre-Cambrian rocks of the area, and it is clearly overlain by the Miocene volcanic rocks. Sandstone belonging to the Morrison formation, of Jurassic age, near the Iron Hill stock contains the minerals peculiar to the stock. A sample collected from the lower part of this sandstone from the hill three-quarters of a mile southwest of Cebolla Hot Springs and less than a mile from the nearest outcrops of the Iron Hill stock contained about 0.5 percent of minerals with a specific gravity greater than 2.89 , whose composition s sparation is as follows:

\begin{tabular}{|c|c|c|}
\hline Biotite_._. & 7 & Amphibole $\ldots \ldots$ \\
\hline Gold & Trace & Opaque \\
\hline Tourma & 10 & Brown garnet... \\
\hline Leucoxene_......... & 17 & Pink garnet.... \\
\hline Diopside_... & 16 & Zircon \\
\hline
\end{tabular}

The leucoxene is in part derived from perofskite. The diopside is rather fresh, pale green and lile that of the Iron Hill rocks. The amphibole is mo tly blue green and was probably derived from the gneisses and amphibolites of the pre-Cambrian, but a few grains are of the bluish amphibole like that of the Iron Hill area. The brown garnet is like the melanite so charqcteristic of the Iron Hill rocks. Specimens of sandstcne of the Morrison formation north of the Iron Hill mass also contain a little of the pyroxene, melanite, amphibole, and perofskite peculiar to the Iron Hill mass. The Iron Hill stock is therefore older than the Morrison (Jurassic) and is later than the latest of the known preCambrian rocks of the area. No further evidence of the age of the Iron Hill stock was found. 

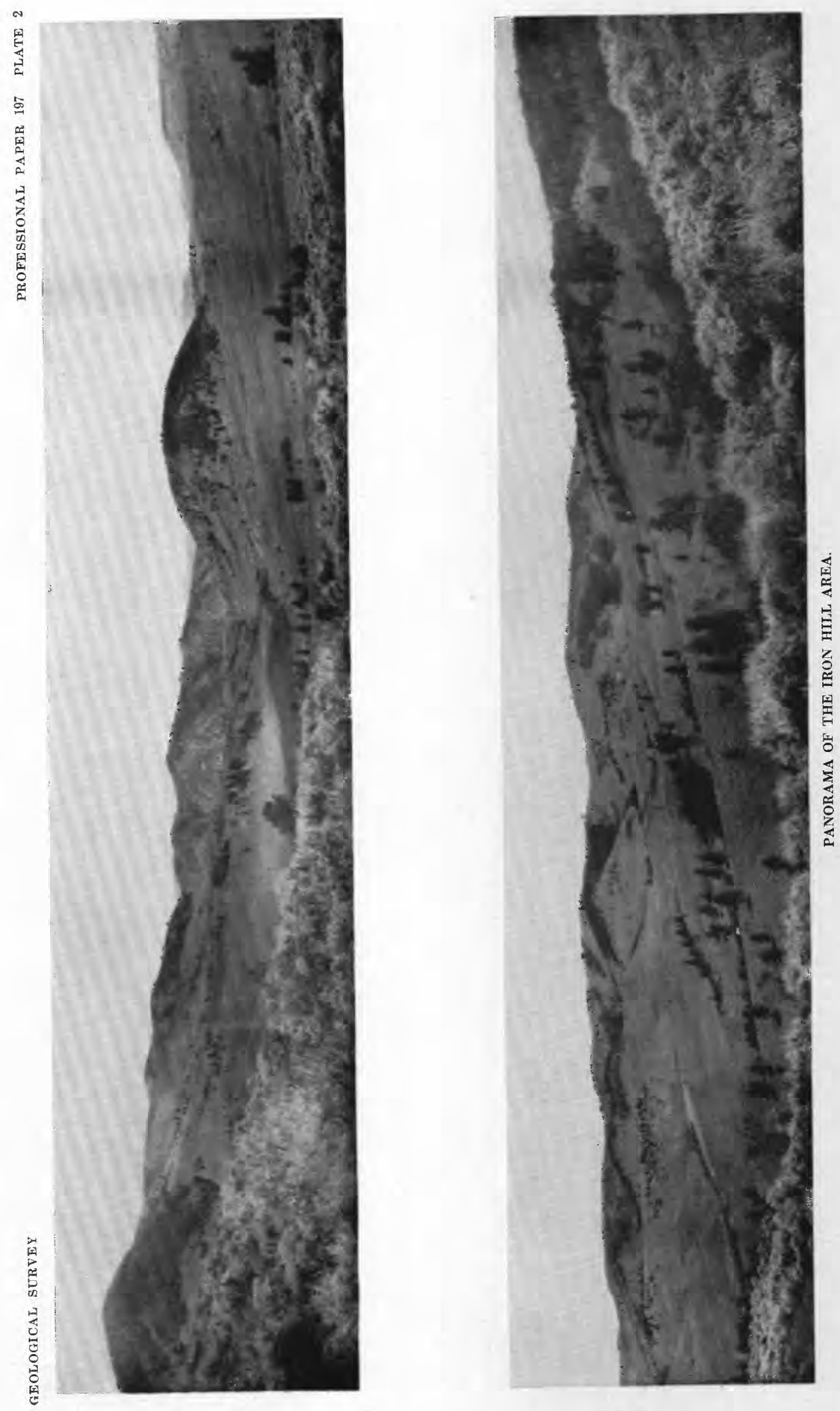
dark minerals. Where not granulated, the rock is commonly coarse-grained and tends to be porphyritic.

A nepheline syenite followed the soda syenite. It has an area of about 0.4 square mile, mostly in the drainage basin of North Beaver Creek. It lies near the border of the stock and in part forms a dikelike body along the border. In general it cuts the pyroxenite, but in places it cuts the syenite and other rocks. One large mass is situated in the upper drainage area of North Beaver Creek, many dikes cut the pyroxenite in an area south of North Beaver Creek, and others cut the older rocks of the stock and the surrounding granite. The rock is medium-grained and is made up chiefly of conspicuous tabular feldspar crystals with some interstitial nepheline and some pyroxene. The feldspar is a perthite rich in albite.

The latest intrusive bodies of the stock consist of gabbro of two varieties, which appear to be closely associated. They are present as a few dikes as much as 100 feet across and over a mile long. The main dikes consist of nepheline gabbro and are in the drainage area of Deldorado Creek, where there are two nearly parallel dikes close together and some smaller dikes. These dikes are medium- to coarse-grained dark rocks with conspicuous tabular crystals of labradorite, much interstitial pyroxene, and smaller amounts of nepheline and olivine. Finer-grained but very similar dikes of quartzbearing gabbro were found near the mouth of Huntsman Gulch, in Deldorado Gulch, on the banks of Cebolla Creek northeast of the Hot Springs, and elsewhere. These rocks have much labradorite, a pinkish titaniferous augite, and a little interstitial, intergrown quartz and orthoclase. They lack nepheline and olivine but are otherwise like the nepheline gabbro.

\section{HYDROTHERMAL ACTIVITY}

Hydrothermal products are widespread and in great variety, as they commonly are about stocks of alkalic rocks. Probably some hydrothermal activity was associated with each of the intrusions.

The most abundant and characteristic hydrothermal minerals are aegirite and a sodic amphibole. They and phlogopite are the chief silicates in the contact-metamorphic marble about the stock, and in the carbonate veins, in fractures in the syenite and other rocks of the stock, and in the granite about the stock. Apatite is also a common hydrothermal mineral, which is present in the marble, in the carbonate veins, in veins with martite, and elsewhere. Magnesic hastingsite is less abundant than the soda-tremolite and related amphiboles and is chiefly an alteration product of pyroxene in the pyroxenite, the uncompahgrite, and other rocks of the stock. It is commonly associated with a pale-green diopside. In places fractures in the pyroxenite are bordered by thin layers of this amphibole. Rarely coarse crystals of hastingsite are present in carbonate veins.
Quartz in small amount is present in some of the veins in the marble and intrusive rocks. Albite and orthoclase are common in the veins and replaced marble and are usually associated with quartz, iron oxide, and apatite. The nepheline is in part altered to analcime, natrolite, cancrinite, or sericite.

A widespread alteration that took place during the transition between the magmatic and the hydrothermal stages is expressed by the presence of dark titaniferous garnet in the uncompahgrite, ijolite, and pyroxenite, and rarely in the other rocks. Grading into this dark garnet is a nearly colorless garnet that was clearly formed by moving solutions. In the uncompahgrite garnet was followed by idocrase and diopside, and then successively by several fibrous, hydrous alteration products of melilite. A little fluorite is present in some of the veins, as are also very sparse sulphides.

\section{SPECIAL FEATURES OF THE STOCK}

The coarse-grained melilite rock, uncompahgrite, the giant cleavage pieces of melilite, and the successive alteration products of the melilite are unique. The nepheline-rich ijolite, the large nepheline fragments, and the alteration products of the nepheline are also unusual.

The abundance of apatite and the titanium minerals, perofskite, and titaniferous garnet, indicating a phosphorous- and titanium-rich magma are unusual. The abundance of hydrothermal amphiboles and aegirite and the unusual character of these amphiboles, the great mass of marble, and the carbonate veins bring up several problems. The variation in the pyroxenite with the apatite-rich varieties, the biotite rock, the magnetiteperofskite rock, and other features deserve detailed study.

\section{"MARBLE" OF IRON HILL DISTRIBUTION}

The marble of Iron Hill occupies an area nearly 2 by $1 \frac{1 / 4}{4}$ miles in dimensions and forms practically all of Iron Hill, which rises nearly 1,000 feet above the Cebolla Valley. It is surrounded by the pyroxenite, except on the west, where it is bordered by the alluvium of Cebolla Valley. This great mass of marble is cut by very few dikes or similar apophyses except near its borders. Smaller bodies of the marble are numerous as inclusions in the igneous rocks near the main mass of Iron Hill, especially in the drainage basins of Beaver and Deldorado Creeks; very few of these are as much as half a mile from the main contact. Near the northwestern border of the pyroxenite a small body of marble only 20 feet or so across is exposed by a prospect pit on the south slope of Sammons Gulch, just below the crest and about a tenth of a mile below the forks of the gulch. This marble is cut by many small dikelike bodies of the pyroxenite, and the pyroxenite nearby carries numerous inclusions of the marble (fig. 1). 
Small bodies of carbonate rock, similar to that of the Iron Hill mass, are present in the pre-Cambrian rock within a few miles of the Iron Hill stock. Most of them are north and west of the area shown on plate 1 . Some of those observed are listed below.

1. Several small masses on the ridge south of Milkranch Gulch about half a mile east of bench mark 8025, which is at the road junctions near the mouth of Milkranch Gulch.

2. Two small bodies on the west side of Cebolla Creek about 300 and 400 yards below the bridge at the mouth of Milkranch Gulch.

3. About a mile south of the last named.

4. Just south of Powderhorn.

5. On the ridge between Deldorado and Beaver Creeks about an eighth of a mile east of the Iron Hill stock. .

6. About a mile southwest of the mouth of Beaver Creek.

\section{CHARACTER}

"Marble."-The greater part of the marble is nearly white millimeter-grained carbonate mineral, with a few percent of apatite grains as the only other important constituent. Of 27 specimens of the marble collected at random, 21 were made up of dolomite, 5 of calcite, and 1 of dolomite and calcite together. In general the calcite marbles are much coarser in texture than the dolomites. In part the outcrops are nearly white, but over large areas the weathered surface is more or less iron-stained, and locally it is a dark yellow brown and contains much limonite. Streaks and irregular patches are so rich in limonite that they have encouraged prospecting for iron ore; yet the average dolomite contains little iron. Exceptionally the carbonate is ankerite. Pyrite, which has been largely altered to iron oxide, is widely distributed in the marble, and locally it is abundant. No bedding and very little variation could be found in the great mass of marble at Iron Hill, except that due to weathering or hydrothermal action.

Martite-apatite veins.-On the southwest slope of Iron Hill the marble is cut by several northeast-southwest veins, as much as several feet across and nearly a mile long, which are made up at the surface of martite, apatite, limonite, and carbonate in varying proportions. They are more or less porous or cavernous, owing to surface leaching. The martite commonly forms streaks or nodules a foot or less across but is partly disseminated in the apatite. The larger bodies of martite are massive in the center but are bordered by well-formed octahedrons of martite an inch or more across. They are clearly hematite pseudomorphs after magnetite, and they are strongly magnetic. ${ }^{2}$

\footnotetext{
${ }^{2}$ Sosman, R. B., and Hostetter, J. C., The ferrous iron content and magnetic susceptibility of some artificial and natural oxides of iron: Am. Inst. Min. Met. Eng. Trans., vol. 58, pp. 425-427, 1917.
}

Siliceous iron-oxide veins. - In addition to the martiteapatite veins, and grading into them, there are irregular veinlike to irregular bodies, rarely over a few feet across, which are porous, rich in limonite and hematite and contain more or less apatite and quartz. Such bodies are well shown and have been prospected for iron near the crest of Iron Hill. Some streaks and bunches of black manganese oxide are present $₹$ nd piedmontite is rare. Local bodies are highly silicif ad and iron-stained. The silica is partly fine-grained and cherty and partly in well-formed, doubly terminated quartz crystals as much as 1 millimeter across. In places orthoclase and rarely albite are associated with the quartz.

Origin of the iron ore.-The iron ore prospects in the limestone are partly in the martite-apatite veins $\varepsilon$ nd partly in bodies of cellular, siliceous iron oxide. The martite veins are small and contain no bodies of martiterich rock much over a foot across. Some of the bocies

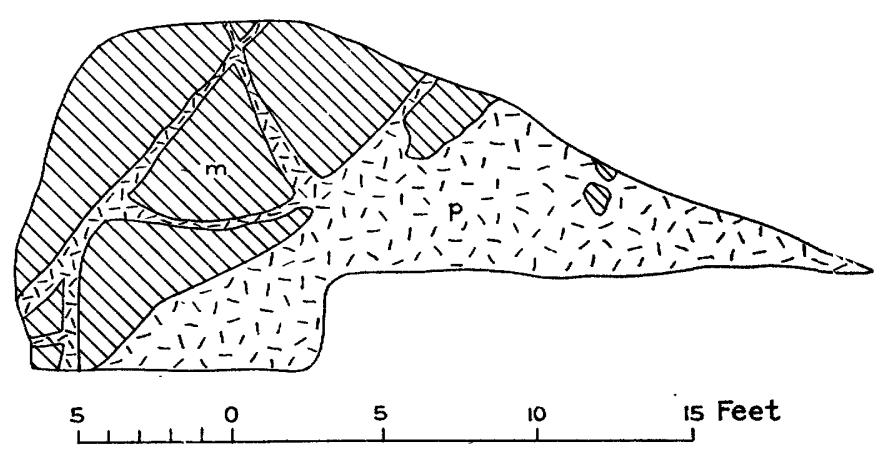

Figure 1.-Marble-pyroxenite contact. Prospect pit on south slope of Samrons Gulch near crest, just west of the lava cap. $m$, Marble; $p$, pyroxenite.

of cellular iron oxide are associated with martite, lyt others lack martite. The largest ones, which lie near the crest of Iron Hill, are only a few feet across and are made up of siliceous cellular limonite with some martite and hematite.

A part of the iron of the iron prospects was deposited as iron oxide (magnetite and hematite) by hightemperature hydrothermal solutions. The magnetite was later oxidized to hematite. Such iron minerals are associated with apatite and some quartz and feldspar. A part of the iron oxide was formed by the oxidation of pyrite and is associated with less apatite and more silica; another part may have resulted from the leaching and oxidation of iron-bearing carbonate.

Silicate rock.-Near the contact with the intrus:ve rocks the marble carries locally more or less aegirite, phlogopite, apatite, and a soda amphibole varying from soda tremolite to glaucophane. These silicates are present in the marble in all proportions from a few scattered tiny crystals to nearly 100 percent. Tl 9y occur chiefly very near the igneous contacts, lut phlogopite has been found in small amounts in streaks in all parts of the marble and is commonly associated with the veins of iron ore. The silicate rocks do not 
form a continuous zone between the marble and the intrusive rock, but, as is commonly true in hydrothermal contact-metamorphic bodies, marble with few or no silicates is in direct contact with the pyroxenite along much of the contact. In part the silicates are in dikelike streaks as much as several feet across, in part in less regular bodies or in bunches scattered through the marble. In places the silicate streaks have sharp contacts with the marble; elsewhere they grade into it. Where exposures are good, as along the road cut up Cebolla Creek north of Beaver Creek, a complicated succession of streaks of marble and silicate zones is present. Some are of nearly pure-white marble, others of iron-stained marble or of carbonate with varying proportions of calcite and mica and other silicates; some streaks lack mica but are rich in amphibole or aegirite, some are harder and have quartz and feldspar, some are coarsely crystalline, others are finely crystalline. Some of the streaks are several feet across; others are only an inch or less.

The common variety of this silicate rock is brown and contains numerous conspicuous flakes of yellow phlogopite a few millimeters across. Where first seen in a streak in the marble it was mistaken for a dike of altered mica lamprophyre. It is readily weathered and in most places is very friable. Where aegirite is the chief silicate the rock shows the greenish grains of aegirite. The carbonate of these silicate rocks is calcite, except in a few specimens that are made up largely of dolomite or very rarely ankerite.

Phlogopite is the most abundant of the silicates, and in places it is the only one present. Some bodies are made up almost entirely of phlogopite. Phlogopite forms crystals that vary in size, the largest several centimeters across, and tend to give the rock a porphyritic appearance. The phlogopite is commonly strongly zoned. Aegirite that contains about 25 percent of the diopside-hedenbergite molecule is the chief silicate in some parts. It is present largely in scattered or matted needles, which vary in size from those visible only with the highest power of the microscope to crystals several decimeters long. It tends to collect into nests or into aggregates of subparallel crystals. Small layers of coarsely crystalline aegirite are rare. Amphibole is nearly as abundant as aegirite and is closely associated with it, although locally only one of them is present. The amphibole occurs in needles piercing the calcite, some of which are very tiny and others a centimeter or more long. Portions of it are poor in iron (soda tremolite) and others rather rich in iron (glaucophane). Many of the crystals are strongly zoned, with the borders poorer in iron.

Fluorapatite forms grains a millimeter or more across and makes up from a few percent to 10 percent or more of the rock. Locally microcline in fairly well formed crystals or as interstitial aggregates forms more or less of the rocks. Albite is less abundant than microcline, and most specimens show no feldspar. Quartz is commonly present only in the rocks with feldspar. Anatase in streaks or aggregates of crystals is widespread, and fluorite is present in some of the quartz veinlets. The minerals are described in the section on mineralogy (pp. 43-56).

Carbonate bodies in the granitic rocks.-The carbonate bodies in the granite surrounding the Iron Hill stock are numerous but small. Most of them are outside the area included on the map (pl. 1). The body west of Cebolla Creek and about 200 yards below the mouth of Milkranch Gulch is a network of branching seams cementing brecciated granite. Few of the serms are over a foot across, but they are so numerous as to make a considerable part of the outcrops for a length of 100 feet and a width somewhat less. The main mass of the veins is white, granular "marble"(?) identical with that of Iron Hjll. Next to the granite' the "marble" contains much fibrous soda tremolite and aegirite and is identical with much of the silicate-bearing contact variety of the marble at Iron Hill. Suites of specimens from this area could not be distinguished from the specimens from the Iron Hill mass. For 100 feet or more about the carbonate veins the closely spaced fractures in the granite are filled with thin layers of soda tremolite and aegirite, identical with those ninerals in the limestone. There seems no escape from the conclusion that these carbonate veins are of hydrothermal origin.

The body of carbonate rock on the ridge south of Milkranch Gulch is poorly exposed but is several feet across. This rock, like that previously described, is made up largely of white "marble" but has strek.ks that are especially abundant near the contacts witk a preCambrian quartz porphyry and contain carbonate, amphibole, aegirite, and phlogopite. So far as can be determined from the poor outcrops, this mass may be either an inclusion of marble in the quartz porphyry or a hydrothermal filling. The body of carbonate rock between Deldorado and Beaver Creeks is much like that south of Milkranch Gulch.

\section{ORIGIN OF THE MARBLE}

\section{AVAILABLE FACTS}

As the evidence for the origin of these marble bodies is not clear or demonstrable, and as the availatle facts may be subject to different, interpretations by geologists with different experience, these facts are reviewed below, before the possible sources of the marble are considered.

Age relations.-Part of the marble is older and part is younger than the intrusive rocks. Some of the smaller bodies are inclusions in the pyroxenite, and some bodies in the surrounding pre-Cambrian granite are hydrothermal fillings in fractures and brecciated zone in the granite. The great mass of Iron Hill is not commonly seen in direct contact with the igneous rocks, but where 
such contacts are seen they indicate that the marble is older than the igneous rocks of the Iron Hill stock. The small body of marble south of Sammons Gulch is an inclusion in the pyroxenite. On the other hand, the carbonate veins are younger than the igneous rocks and cut them cleanly.

Character of the marble at Iron Hill.-The main body of the marble is well exposed in a mass more than a mile wide and for a vertical thickness of about 1,000 feet, yet it lacks any evidence of bedding, shale layers, or other irregularities. Except where it has been hydrothermally altered, it is a fairly pure carbonate, chiefly dolomite, with a little apatite and pyrite as the chief impurities. Near the borders it is irregular in character and contains streaks and bunches of phlogopite, aegirite, and a soda amphibole. The silicate minerals are distributed irregularly in the contact zone and occur partly in thin streaks or seams. The aegirite and hornblende tend to be fibrous in habit and to be aggregated in bunches and streaks, after the manner of these minerals in hydrothermally metamorphosed rocks. Microcline or albite and quartz are locally abundant. The aegirite and hornblende are identical with the minerals that are abundant as seams and along the sheeting fractures and other openings in the syenites and pre-Cambrian granites. Seams of pyrite and other sulphides and of apatite and martite cut the main mass of limestone.

Carbonate in the pre-Cambrian rocks.-The small bodies of carbonate in the pre-Cambrian rocks are made up of rock that is identical with the marble at Iron Hill, both in texture and in mineral composition. Some of the bodies are hydrothermal fillings of fractures in the granitic rocks, and the others would seem to be best attributed to the same origin.

Character of the carbonate veins. - The carbonate veins are very numerous. Some are a mile long, but few are more than 20 feet across. Many of the veins have centers of dolomite or ankerite with some apatite and small quantities of galena, sphalerite, pyrite, and other sulfides. The borders of some of the veins are calcite with mica, aegirite, and hornblende. Specimens from the borders of the veins are almost identical with those from the contact zone of the Iron Hill mass.

The pyroxenite shows little alteration next to the veins, although a narrow border of aegirite may grow about the pyroxene grains, and a little hornblende like that of the veins may be formed at the immediate contact. These reaction zones are measured in fractions of a millimeter.

Primary calcite in the pyroxenite.-The pyroxenite near the marble has some primary calcite. This calcite is neither abundant in amount nor widespread and appears to be developed chiefly near bodies of included limestone, but this relation is not beyond question.

Metamorphism of the marble.-The marble has been so greatly metamorphosed that it is not likely that any structure, texture, or other relict character of the original rock now remains except its chemical composition and variations in composition, such as would result from the recrystallization of interbedded shale or impure limestone.

Origin of the silicates in the marble.-The irrecular distribution of the silicates in the marble, their concentration near the contacts, and their habit and texture are those characteristic of hydrothermal contact-metamorphic bodies such as the tactite bodies about gr? nodiorites. The character of the silicates-aegirite, soda tremolite, and phlogopite - and their fibrous habit and distribution in the marble are evidence of a hydrothermal origin. They are certainly not igneous. Moreover, the peculiar minerals and textures of the rocks are those characteristic of the hydrothermal deposits of the area. They are present in the hydrothermal carbonate deposits, in the granitic rocks surrounding the stocl, in the carbonate veins that cut the rocks of the stock, and in very numerous seams and veins in both the stock and the granites surrounding the stock. They also replace the primary dark minerals in parts of the syenite and other rocks of the stock. The same peculiar amphibole is the chief hydrothermal mineral in the stock, which is much like the stock at Libby, Mont., ${ }^{3}$ and aegirite is present in the veins at Libby. The same amphiboles and aegirite are abundant as hydrothermal minerals in the rock of the Fen district, Norway, as I have observed in specimens in the Harvard collections. It seems certain that the silicates in the marble ara of hydrothermal origin.

Carbonate rock is common in stocks of similar cl $\mathrm{nr}$ acter. Bodies of carbonate rock much like that at Iron Hill are found associated with alkalic rocks of this type in the Fen district, Norway, and elsewhere, but not in all such provinces. The carbonate rock is a common if not a characteristic feature of such petrographic provinces and is highly significant.

\section{MODES OF ORIGIN}

The following modes of origin for the marble app ear to merit consideration: They may be (1) inclusions of pre-Cambrian limestone; (2) inclusions of Paleozoic limestones, settled into the stock; (3) bodies of Paleozoic or older limestones that have been forced into ts air present position by plastic flow; (4) true igneous injections of molten dolomite and calcite; (5) a replesement of an older rock by hydrothermal soluticns; (6) a filling deposited by hydrothermal solutions. These various modes of origin are discussed below.

1. The marble at Iron Hill may be an inclusion of rreCambrian limestone in the Iron Hill stock. In the early stages of the work in the area this was believed to be the most probable origin, chiefly because the small bodies of similar carbonate rock in the pre-

${ }^{3}$ Larsen, E. S., and Pardee, J. T., The stock of alkaline rocks near Libby, Mont. Jour. Geology, vol. 37, pp. 102-111, 1929. 
Cambrian granite were thought to be inclusions. Later more careful study of these small bodies of carbonate has shown that some are without doubt veinlike bodies cutting the pre-Cambrian and that all of them are probably hydrothermal deposits in the granitic rocks.

The great size of the dolomite of Iron Hill and the lack of bedding or shaly layers is difficult to explain as an inclusion of limestone. Such large, structureless bodies of marble are known in the Grenville of the Adirondack region and elsewhere, but marble is extremely rare in the pre-Cambrian of Colorado, ${ }^{4}$ and the few bodies that are known are small and impure. No marble is known in the pre-Cambrian near Iron Hill, and none would be expected in the great mass of gneisses, amphibolites, and granitic rocks. The marble resembles a huge block of unusually pure dolomite, included in the pyroxenite and irregularly metamorphosed near the contacts, with the introduction of silicates and other minerals, and at the same time the development of calcite by dedolomitization. It seems improbable, however, that the marble at Iron Hill is an inclusion of pre-Cambrian limestone, as there is no likely source for such a mass of limestone.

2. The marble may be a body of Paleozoic limestone dropped into the Iron Hill stock. This would make the Iron Hill stock of Paleozoic or early Mesozoic age, and there is no evidence opposed to such an age. This interpretation is open to most of the objections made in the preceding paragraph, except that large bodies of limestone are known to be present in the Paleozoic of this area. However, no beds of pure limestone or dolomite without shaly layers much over 100 feet thick are present in this part of Colorado and none that could have furnished a block of pure limestone like the Iron Hill mass. That the marble at Iron Hill is an inclusion of Paleozoic limestone also seems improbable.

3. The marble may have been forced into its present position by plastic flow of an older dolomitic limestone bady. This would seem to require that the source of the limestone should be pre-Cambrian, as the limestone is enclosed in pre-Cambrian rocks, and it seems very improbable that the Paleozoic dolomitic limestones, which are nowhere known to be greatly metamorphosed, could have been forced down into the pre-Cambrian. The source limestone in the pre-Cambrian need not have been so pure as that required for a dolomitic limestone inclusion (method 1). The limestone must have been forced into the pre-Cambrian before the eruption of the rocks of the Iron Hill stock, and both the main limestone mass and some of the smaller bodies in the pre-Cambrian might be explained in this way. The later carbonate veins might be later injections. One serious objection to this method is the fact that the

Cross, C. W., Marble in Tin Cnp Pass: Colorado Sci. Soc. Proc., 1893, pp. 1-10. borders of the post-stock veins and of the bodies of limestone in the pre-Cambrian granites have the same silicates and other minerals as the main mass of limestone near the Iron Hill stock. The lack of known limestone bodies in the pre-Cambrian is another objection. This source for the marble would therefore seem to be very improbable.

4. The marble may be an igneous rock. Brögger ${ }^{5}$ and Brauns ${ }^{6}$ have advocated such an origin for the similar marble of the Fen district and other areas. Brögger believes that in the Fen district a carbonate magma and a silicate magma, related to ijolite, existed at the same time, that the pure carbonate rock was derived from the carbonate magma, and that tha mixed carbonate-silicate rocks were formed either by mixing of the two magmas or by reaction of one magma, chiefly the carbonate magma, on solidified rock. These mixed rocks may be made up of any proportion of carbonate (calcite or dolomite) and the minerals of the silicate rocks. They occur chiefly as dikes, and some of the dikes are relatively uniform from wall to wall, whereas others are made up of a central part rich in calcite and border zones that grade into the adjoining silicate rock. I found no such mixed rocks in the Iron Hill area.

Brögger's chief arguments for an igneous origin for the main mass of nearly pure carbonate are its similarity to the carbonate-silicate dike rocks of the area, the lack of a body of limestone that could yield the great mass of carbonate, and the lack of any evidence of replasement.

Bowen ${ }^{7}$ has concluded that for the Fen $\varepsilon$ rea the mixed carbonate-silicate rocks are not igneous $k$ it were formed by partial replacement of silicate rocks by carbonate and that the pure carbonate rocks represent the complete replacement. Brauns ${ }^{8}$ later maintained an igneous origin.

The difficulty of melting a carbonate rock might also be raised as an objection, as $\mathrm{CaCO}_{3}$ melts at about $1,340^{\circ}$ at 1,000 atmospheres pressure of $\mathrm{CO}_{2}{ }^{9}{ }^{9}$ This is not an insuperable difficulty, as syenite, granite, pyroxenite, and many other rocks can be made fluid only at very high temperatures, yet we believe they are igneous rocks rendered fluid through the presence of mineralizers.

In the Iron Hill area there is nothing about the marble to suggest an igneous rock, except possibly the rather large amount of apatite present in large grains in most of the dolomite. The silicates are confined to streaks and to the contact zone and are of hydrcthermal contact-metamorphic origin. However, the marble might have been injected as a relatively pure dolomite,

\footnotetext{
5 Brögger, W. C., Das Fengebjet in Telemark, Norway; Vidensk. selsk Oslo Forh. 1920, No. 9, pp. 262-275.

- Brauns, R., Primärer Calcit in Tiefengesteinen oder Verdrängung der Silikate durch Calcit?; Centralbl. Mineralogie, 1936, Abt. A, pp. 1-8.

7 Bowen, N. L., The Fen area in Telemark, Norway; Am. Jour. Sei., 5th ser., vol. 8, pp. 1-11, 1924.

B Brauns, R., op. cit.

Adams, L. H., and Smythe, F. H., The system calcium oxide-carbon dioxide: Am. Chem. Soc. Jour. vol. 45, p. 1184, 1923.
} 
carrying a little apatite, as the first magma of the Iron Hill stock and have been later metamorphosed by the pyroxenite. I know of no way to tell such a dolomite from any other dolomite especially after metamorphism. However, until the possibility or probability of a carbonate magma is better established, it would seem to be wiser to avoid such an interpretation unless there is some favorable evidence. The only evidence favoring such an origin is that it would easily explain the large mass of uniform marble. To me an igneous origin seems improbable, but to the advocates of igneous marbles it will seem the most probable mode of origin.

5. The marble may have replaced an older rock by hydrothermal solutions. This is the origin advocated by Bowen ${ }^{10}$ for the similar rock of the Fen area. Bowen's argument is based on a brief study in the field and a microscopic study of his collections. He found microscopic evidence that the carbonate had replaced to a greater or less extent the feldspar, nepheline, and other minerals of the syenite, ijolite and other rocks of the area and that the silicates in the mixed carbonatesilicate rocks were relicts found in all stages of replacement. The purer carbonate rocks were formed by complete replacement of the igneous rocks.

In the Iron Hill area the marble is older than the igneous rocks of the stock, with the possible exception of the uncompahgrite, with which it has nowhere been seen in contact. Silicates, except in very minor amounts, are found in the marble, only near the contact with the pyroxenite, and these silicates are not like the primary minerals of the pyroxenite or of any of the other rocks of the stock. They are, in respect to mineral species and habit, identical with the minerals that are widespread as hydrothermal minerals, both in the rocks of the stock and especially in the surrounding granites and schists. They were no doubt formed by hydrothermal contact metamorphism of the marble. The main mass of the marble is a relatively pure dolomite with no remnants of partly replaced rock or other observable indications that it has replaced an older rock. No rock is known in the area that might reasonably be expected to undergo such large scale and complete replacement.

6. The marble may have been deposited as a filling by hydrothermal solutions. The fact that the small bodies of carbonate in the granite are of hydrothermal origin would favor a similar origin for the large body of Iron Hill, but it has already been shown that the large body of marble at Iron Hill is older than the Iron Hill stock. Such a large body, rounded in outcrop, is not easily explained as an open-space filling. It might be interpreted as a filling in the throat of an old volcano in which the lava column had sunk to great depths or the throat had been cleared out by a great explosion.

${ }^{10}$ Bowen, N. L., op. cit.
The post-pyroxenite carbonate veins are clearly veinlike in form. They carry some galena and other sulfides, and some, at least, carry fragments of the pyrosenite. Locally they grade into fluorite veins. Thay have border zones that contain the silicates (phlogopite, aegirite, and an amphibole) though the main parts of the veins are nearly pure dolomite or ankerite. $\mathrm{T} e$ pyroxenite wall rock next to the veins is very little altered-less so than would have been suspected along hydrothermal veins.

The close similarity of the large marble mass of Iron Hill to the much smaller masses in the pre-Cambrian that are shown on page 6 to be hydrothermal openspace fillings and the close similarity to the later cerbonate veins strongly favor a hydrothermal origin for the marble at Iron Hill. The great size of the mass is the chief objection to an origin of this kind. In view of all the evidence, the inference that the marble in its original form was deposited by a hydrothermal solution in the open throat of an old volcano, later modified by the successive intrusions of the members of the stock, seems more probable than any other, althourh it cannot be proved.

\section{UNCOMPAHGRITE}

\section{OCCURRENCE}

The uncompahgrite, a coarse-grained rock made up predominantly of melilite, was found only in the Beaver Creek drainage basin, chiefly south of the main creok and between the forks. The largest body lies near the southern boundary of the Iron Hill intrusive stock and on both sides of South Beaver Creek. The mass extends about a mile east and west and nearly half a mile north and south. It is cut by the ijolite and pyroxenite. Small remnants lie just south of North Beaver Creek. Another dikelike strip, two-thirds of a mile long and nearly 0.1 mile wide, lies a short distance to the northwest and just southwest of the main forks of Bearer Creek. A very irregular body connects with this dilelike strip at its southwest end and occupies a considerable area in the drainage basins of gulches $\mathrm{B}$ and $\mathrm{C}$ south of Beaver Creek. A small outcrop lies on the north side of Beaver Creek just above the alluvium. An extremely irregular mass lies just east of the Cebola Valley, south of Beaver Creek, and northeast of gulch A. In addition to these bodies, many smaller inclusions lie in the pyroxenite near the larger bodies. The relations are very complex and the exposures are porr, so that the distribution shown on the geologic map is much generalized. The total area underlain by the uncompahgrite is about 0.6 square mile.

\section{FRESH UNCOMPAHGRITE}

The fresh uncompahgrite is a light-gray rock witl a vitreous to greasy luster on the fresh fracture, but on the weathered surface it is nearly white and has a dull 
luster. The rock is in general coarse-grained but varies in texture, the grains ranging from 1 millimeter to 50 centimeters. Cleavage surfaces of melilite 0.5 meter across are common. The uncompahgrite is made up chiefly of the mineral melilite, which has a greasy luster and imperfect cleavage. In the coarse-grained rocks the melilite encloses the other minerals poikilitically, but in the fine-grained varieties it forms anhedral interlocking grains between the other constituents. In the average rock melilite makes up about 68 percent, diopside-hedenbergite about 15 percent, pale-green phlogopite 2 percent, magnetite 10 percent, perofskite 3 percent, apatite 1 percent, and primary (?) calcite a small amount. Nepheline and primary garnet are present in rare specimens. The proportion of the constituents varies considerably, though much less than in the pyroxenites. In some places the rock is nearly pure melilite, but in others amost half or even over half of it is composed of dark minerals.

The pyroxene is in prisms enclosed in the melilite or embedded in the fine-grained melilite. It is pale green in thin section and much of it is surrounded by a thin border of garnet. The phlogopite is very pale green or brown and is present in plates or irregular grains. It tends to border the perofskite, apatite, and magnetite. Next to the perofskite it shows yellow pleochroic halos but not against the other minerals.

The apatite has optical properties almost identical with those of melilite, but it can nearly always be distinguished by its prismatic habit and the common occurrence of included gas bubbles. In the hand specimen it can be recognized as white prisms in the darker granular melilite. In some parts a chemical test is necessary to distinguish the two. The perofskite is in well-formed purplish-brown grains or intergrown with magnetite and it shows faint birefringence and the usual twins. The primary (?) calcite fills in between the other constituents and commonly is surrounded by garnet reaction rims.

The uncompahgrite is a unique rock, and the rock closest to it appears to be the turjaite from Kola Peninsula, Russia. According to Kranck ${ }^{11}$ turjaite is a medium- to coarse-grained rock made up chiefly of melilite, nepheline, biotite, ore, perofskite, and some melanite. It therefore differs from uncompahgrite in having nepheline and biotite and in lacking pyroxene.

\section{AITERED UNCOMPAHGRITE}

As the alterations of the uncompahgrite have been described in detail elsewhere, ${ }^{12}$ only a brief description will be given here. The uncompahgrite offers an unusually good opportunity to trace a series of reactions and replacements of melilite and other minerals,

11 Kranck, E. H., On turjaite and the ijoilte stem of Turja, Kola: Fennia 51, pp. 12-37, 1928.

12 Larsen, E. S., and Goranson, E. A., The deuteric and later alterations of the uncompahgrite of Iron Hill, Colo.: Am. Mineralogist, vol. 17, pp. 343-356, 1932. ranging from those caused by the residual liquer of the crystallizing magma before it separated from the crystal mesh to those caused by hydrothermal solutions that gathered into fractures and were probal' $y$ relatively dilute.

The first replacement formed a very small amount of light-colored perofskite in narrow rims, associated with some phlogopite, about the darker-colored magmatic perofskite and to a less extent about magnetite. This was followed by a larger-scale replacement of melilite by dark titaniferous garnet that formed either irregular grains or, more commonly rims about perofskite, magnetite, and pyroxene, and to a less extent about melilite grains. In a few specimens a thin ragged layer of garnet completely borders and separates the melilite grains as well as the other minerals, forming a network of garnet. A little phlogopite is associated with the garnet; it is in part later than the garnet, as it forms narrow ragged fringes about the garnet crystals and in places appears to have replaced it.

$A$ vein about 10 centimeters wide cutting the uncompahgrite exposed south of Beaver Creek, in the bed of gully $\mathrm{C}$ about 250 yards below its forks, was formed by moving solutions. The borders of this vein are made up chiefly of brown garnet with some pale-green phlogopite, pleochroic green chlorite, calcite, and fibrcis zeolites. Next to this zone and grading into it is a zore made up mostly of coarse idocrase in which are embedded crystals of monticellite. The center is made up of large grains of cancrinite containing embedded grains of monticellite ${ }^{13}$ and some of the brown garnet.

At the time of the deposition of the garnet and phlogopite the magma must have been almost completely crystalline, and the amount of interstitial liquid could not have exceeded a few percent. The formation of the garnet may have been partly caused by the residual interstitial liquid before that liquid had moved from the interstices between the crystals, but the uneven distribution of the replacement and particulerly the presence of the veinlike bodies of garnet rock show that the liquid had moved somewhat and had collected in fractures and other channelways. It seems frobable that this replacement was transitional between a truly magmatic reaction and a hydrothermal reaction (due to moving solutions enriched in water). ${ }^{14}$

${ }^{13}$ Larsen, E. S., and Foshag, W. F., Canerinite as a high-temperature bydrothermal mineral from Colorado: Am. Mineralogist, vol. 11, pp. 300-303, 1926.

14 Brown, I. A. (Geology of the south coast of New South Wales, pt. 3, The monzonite complex of Mount Dromedary: Linnean Soc. New South Wales P xc., vol. 55, p. 690,1930 ), speaking of the relation between the melanite-bearing series and the nepheline monzonite, says: "In other places there scems to be a graduel transition from the one series to the other, as though the garnet were partly of pnzumatolytic origin, or at least had been formed during the final phases of consolidation of the rock."

Holmes, A., and Harwood, H. F., Petrology of the volcanic fields east and southeast of Ruwenzori, Uganda: Geol. Soc. London Quart. Jour., vol. 88, p. ₹97, 1932.

Shands, S. J., The nepheline rocks of Sekukuniland: Geol. Soc. South Africa Trans., vol. 24 , p. 127,1921 .

Kranck, E. H., On turjaite and the ijolite stem of Turja, Kola; Fennia 51, no. 5, p. 22, 1928. 
After the deposition of the garnet but in part contemporaneous with it, idocrase and colorless diopside began to replace melilite. In some large bodies of uncompahgrite the melilite has been completely replaced; in other large bodies the melilite is unaltered except for scattered thin veinlets of the secondary minerals. In places the veinlets are so abundant that only remnants of fresh melilite remain. The alteration started chiefly from fractures in the rock and worked out from them. In part it began at the borders of the melilite grains, or about grains of magnetite or other minor constituents as centers, and spread out, forming spherulitic bodies of the secondary minerals. In one specimen a thin network of diopside separates the melilite grains, and areas of diopside enclosing several melilite grains give simultaneous extinction.

The minerals produced by this replacement are colorless diopside, colorless garnet, and idocrase with some calcite. Chlorite, muscovite, titanite, and amphibole are in places associated with these minerals and are probably of late origin. The minerals occur in fine intergrowths in many of the rocks, in part resembling micropegmatitic intergrowths. In part the diopside is in plumose or arborescent aggregates penetrating the garnet or idocrase, and in part it formed in widely radiating aggregates from the grains of magnetite, perofskite, apatite, diopside, and other minerals or from the planes of the fracture along which the altering solutions moved. In general the idocrase and diopside appear to have been formed together, but in some specimens the diopside followed the idocrase.

In some of the rock where the replacement was most nearly complete the replaced rock is a coarse-grained aggregate of garnet, idocrase, diopside, and some calcite, together with the original minerals of the uncompahgrite, except the melilite, which has disappeared by replacement. In these aggregates the minerals tend to be intergrown, much as they are in the lime-silicate hydrothermal contact-metamorphic replacement deposits of limestone.

Later alterations of the melilite formed these products in the following order: (1) Sheaves of finely fibrous juanite, (2) undertermined fibrous mineral A, (3) cebollite, (4) undetermined mineral B.

Brugnatellite was found locally. Hastingsite replaced the pyroxene in small amount, and soda tremolite and aegirite were formed in seams; they were probably a result of the intrusion of the uncompahgrite by pyroxenite.

The sequence in the crystallization and later replacements in the uncompabgrite are summarized in table 1.
TABLE 1.-Sequence in the crystallization and paulopost replacements of the uncompahgrite

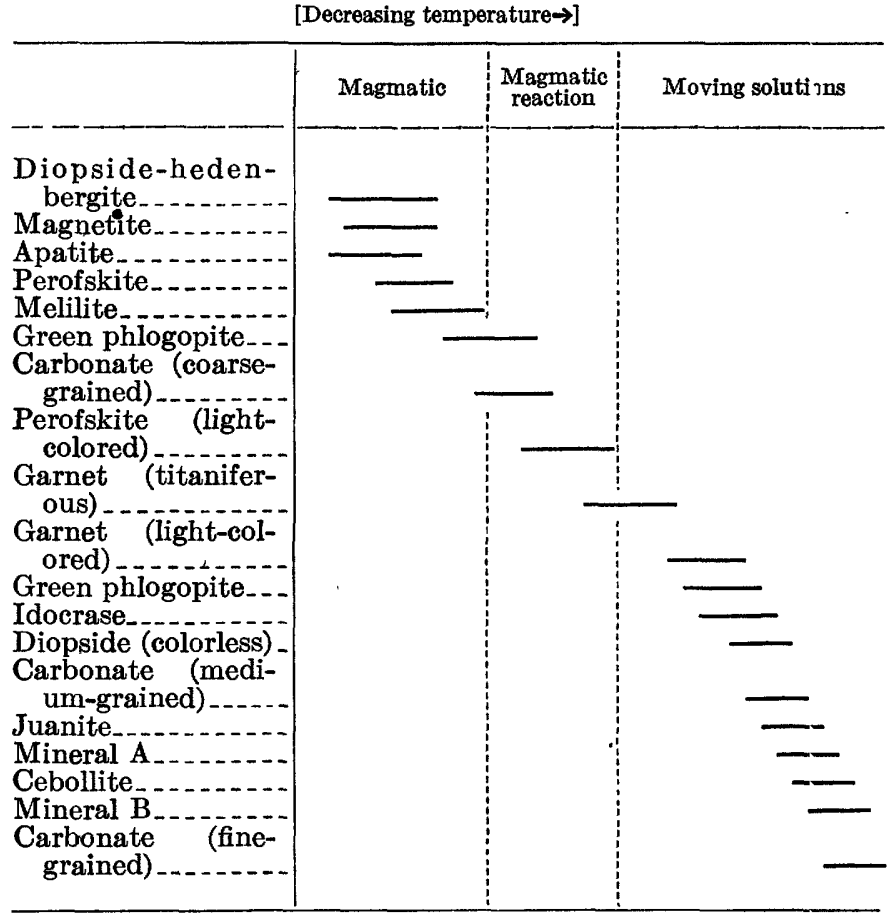

CHEMISTRY OF THE ALTERATION PRODUCTS

The analyses of the melilite and of some of the alteration and replacement products, arranged in the order in which they were formed, are given in tak ${ }^{-1} e 2$. The first replacement product, perofskite, involved chiefly a substitution of silica by titania and took place on a very small scale. The second product, titaniferous garnet, formed partly in the very late magratic stage but continued into the very early hydrothermal stage, when the solutions were collecting and moving along fractures and other channelways. An anclysis of a similar titaniferous garnet from the ijolite of the Iron Hill area is shown in column 3. This replacement of melilite by garnet involved a loss of silica, alumina, magnesia, lime, and alkalies, a large gain in ferric iron, and considerable gain in titania. Some of the alumina and magnesia may have gone into the biotite, which commonly accompanies the garnet in small amount. The late light-colored garnet has much less titania and iron oxide.

The third replacement appears to have followed the first closely and was clearly caused by moving solutions. In it, the melilite was replaced by a mixture comfosed chiefly of idocrase and diopside, with some carbonate, garnet, and other minerals. An analysis of uncompahgrite in which the melilite was completely altered to a coarse aggregate made up chiefly of idocrase and diop- 
side is shown in table 2, column 4 . It should be compared with analysis (2) which represents fresh uncompahgrite. The approximate composition of this alteration product indicates, as does an examination under the microscope, a mixture made up about half of idocrase and a quarter of diopside. In this replacement there was little change in bulk composition-an oxidation of iron, a loss of nearly all the alkalies and a gain of about 2 percent of water.

In the next large-scale replacement to juanite, shown in column 5, there was a loss of alumina and alkalies and a gain in magnesia and water, although the changes were not great.

In the alteration to cebollite (column 6) there was a considerable gain in alumina and water, a large loss in silica and an oxidation of the iron.

TABLE 2.-Analyses of melilite, uncompahgrite, and replacement products

\begin{tabular}{|c|c|c|c|c|c|c|}
\hline & 1 & 2 & 3 & 4 & 5 & 6 \\
\hline 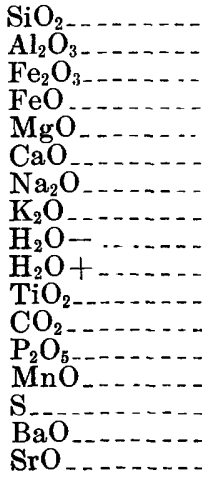 & \begin{tabular}{r}
44.13 \\
10.80 \\
\hdashline 2.04 \\
4.35 \\
33.81 \\
3.40 \\
Tr. \\
.49 \\
.03 \\
.82
\end{tabular} & $\begin{array}{r}38.04 \\
6.34 \\
8.45 \\
5.90 \\
7.81 \\
27.19 \\
2.16 \\
.12 \\
.22 \\
.48 \\
1.98 \\
.30 \\
.24 \\
.23 \\
.02 \\
.26\end{array}$ & 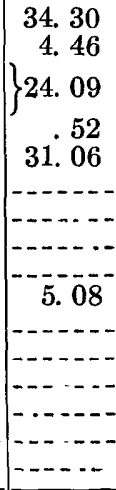 & \begin{tabular}{r}
40.01 \\
5.41 \\
7.12 \\
1.08 \\
8.89 \\
30.99 \\
.60 \\
\hdashline .52 \\
2.00 \\
1.00 \\
1.51 \\
.88 \\
.11 \\
.06 \\
.21
\end{tabular} & \begin{tabular}{r}
42.05 \\
5.19 \\
3.26 \\
9.52 \\
34.68 \\
1.06 \\
.14 \\
4.45 \\
None \\
\hdashline..- \\
.09 \\
-2
\end{tabular} & $\begin{array}{r}33.02 \\
14.02 \\
3.43 \\
.21 \\
4.69 \\
35.72 \\
2.57 \\
\text { Tr. } \\
\text { None } \\
6.26 \\
\\
\\
\\
\\
\end{array}$ \\
\hline $\begin{array}{l}\text { S p e e if i c } \\
\text { gravity }\end{array}$ & $\begin{array}{r}100.03 \\
2.98\end{array}$ & $\begin{array}{r}99.74 \\
3.29\end{array}$ & $\begin{array}{r}99.51 \\
3.67\end{array}$ & $\begin{array}{r}100.39 \\
3.24\end{array}$ & $\begin{array}{r}100.44 \\
3.015\end{array}$ & $\begin{array}{r}99.92 \\
2.96\end{array}$ \\
\hline
\end{tabular}

1. Melilite from Iron Hill computed free of impurities, W. T. Schaller, analyst; $\mathrm{BaO}$ and SrO by F. A. Gonyer.

2. Typical fresh, fine-grained uncompahgrite, George Steiger, analyst.

3. Titaniferous garnet fromijolite of Iron Hill. Much like the garnet of the uncom pahgrite. Approximate analysis by W. T. Schaller.

4. Uncompahgrite in which the melilite has been altered to a coarse aggregate of idocrase, diopside, etc. U 197, F. A. Gonyer, analyst.

5. Juanite, F. A. Gonyer, analyst.
6. Cebolli te. W. T. Schaller, analyst.

The approximate percentages of losses and gains in the major oxides and the changes in specific gravity that took place during the successive alterations are shown in table 3.
TABLE 3.-Approximate chemical changes in the replasement of melitite

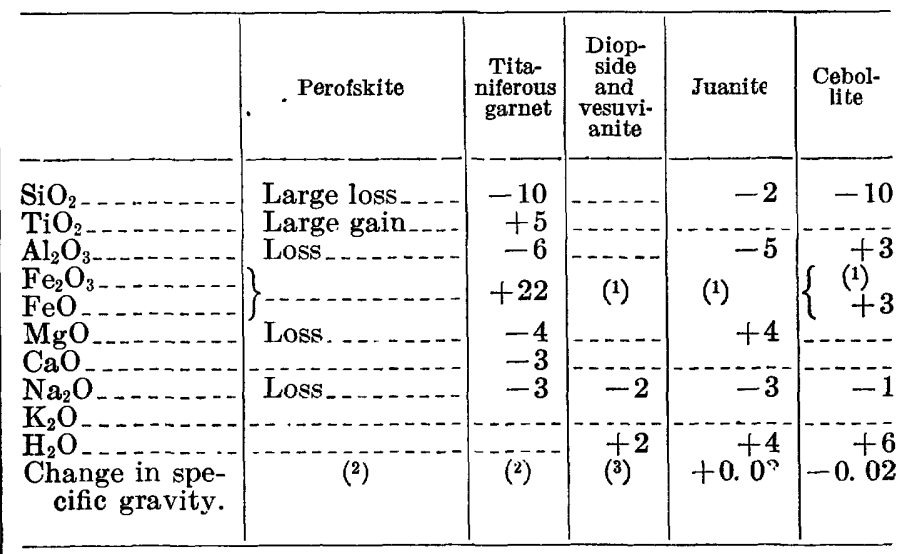

1 Oxidation.

2 + Large

CHEMICAL ANALYSES, NORMS, AND MODFS

Two analyses of the fresh uncompahgrite hrve been made and are given in table 4, together with analyses of similar rocks from other localities. Analysis 1 represents the uncompahgrite with giant melilite, and analysis 2 a finer-textured rock. The uncompahgrite is a rather uniform rock, and therefore the two analyses are much alike. As would be expected from the mineral composition, the rocks are very high in lime-higher than any other known igneous rocks except the doubtful carbonate rocks and two specimens of rodingite (diallage-garnet rock) in which the lime lies between that of the two uncompahgrites. The uncompahgrites are very low in silica for rocks made up almost er.tirely of silicates and also are low in alumina and potash.

The cromaltite (analysis 3 , table 4 ) is rearer in chemical composition to the uncompahgrite than any other analyzed rock. ${ }^{15}$ It contains less silica, lime, and magnesia and more alumina, total iron, alkalies; titania, and phosphoric acid than the unoompahgrite. Some of the unusual varieties of the uncompahgrite with more apatite, perofskite, or titaniferous garnet and magnetite and a little nepbeline would be nearer the crmmaltite, although the lime would still be high.

The olivine gabbro from Madagascar (analysis 4) as compared with the uncompahgrite is higher in silica

${ }^{15}$ Shand, S. J., On borolanite and its associates in Assynt: Edinbu*gh Geol. Soc. Trans., vol. 9, p. 395, 1910. 
and alumina and lower in lime, magnesia, alkalies, and titanium.

The rodingite (analysis 5) is much higher than the uncompahgrite in alumina and water, lacking in alkalies, and somewhat lower in magnesia and silica. It is a diallage-garnet rock.

The turjaite (analysis 6) is mineralogically much like the uncompahgrite, but it has nepheline and biotite. Chemically it has more alumina and alkalies and less lime than the uncompahgrite.

TABLE 4.-Analyses, norms, and modes of uncompahgrite and related rocks

\begin{tabular}{|c|c|c|c|c|c|c|c|}
\hline \multicolumn{8}{|c|}{ Analyses } \\
\hline & 1 & 2 & A & 3 & 4 & 5 & 6 \\
\hline $\begin{array}{l}\mathrm{SiO}_{2} \\
\mathrm{Al}_{2} \mathrm{O}_{3} \\
\mathrm{Fe}_{2} \mathrm{O}_{3} \\
\mathrm{FeO} \\
\mathrm{MgOO} \\
\mathrm{CaO} \\
\mathrm{Na}_{2} \mathrm{O} \\
\mathrm{K}_{2} \mathrm{O} \\
\mathrm{H}_{2} \mathrm{O} \\
\mathrm{H}_{2} \mathrm{O} \\
\mathrm{TiO}_{2} \\
\mathrm{CO}_{2} \\
\mathrm{P}_{2} \mathrm{O}_{5} \\
\mathrm{MnO} \\
\mathrm{ZrO}_{2} \\
\mathrm{~S}\end{array}$ & $\begin{array}{r}38.57 \\
5.79 \\
5.41 \\
3.33 \\
8.44 \\
30.72 \\
2.34 \\
.42 \\
.34 \\
.62 \\
1.71 \\
1.28 \\
.83 \\
.16 \\
.02 \\
.03 \\
.28 \\
.35 \\
\end{array}$ & $\begin{array}{r}38.04 \\
6.34 \\
8.45 \\
5.90 \\
7.81 \\
27.19 \\
2.16 \\
.12 \\
.22 \\
.48 \\
1.98 \\
.30 \\
.24 \\
.23 \\
.02 \\
\hdashline .26\end{array}$ & $\begin{array}{r}38.3 \\
6.1 \\
6.9 \\
4.6 \\
8.1 \\
29.0 \\
2.2 \\
.3 \\
.3 \\
.5 \\
1.8 \\
.8 \\
.5 \\
.2 \\
\text { Tr. } \\
\text { Tr. } \\
.3 \\
.3\end{array}$ & \begin{tabular}{r}
33.52 \\
7.60 \\
10.69 \\
6.98 \\
6.94 \\
22.82 \\
3.52 \\
1.37 \\
\hdashline 4.51 \\
2.31 \\
\\
\end{tabular} & $\begin{array}{r}43.90 \\
11.26 \\
2.36 \\
8.78 \\
6.26 \\
24.90 \\
.98 \\
.24 \\
.10 \\
.66 \\
.59 \\
.14 \\
-.\end{array}$ & $\begin{array}{r}35.34 \\
13.36 \\
6.24 \\
5.18 \\
6.61 \\
27.34 \\
\text { None } \\
4.03 \\
1.54 \\
\text { None } \\
\\
\text { None } \\
.02 \\
.05\end{array}$ & $\begin{array}{r}34.72 \\
12.19 \\
6.44 \\
4.82 \\
5.84 \\
19.08 \\
5.11 \\
3.05 \\
.17 \\
2.13 \\
3.31 \\
.81 \\
1.88 \\
.28 \\
.17 \\
\\
\end{array}$ \\
\hline & $|100.64|$ & $|99.74|$ & - & $|100.26|$ & $|100.17|$ & 99.71 & 100.00 \\
\hline
\end{tabular}

\begin{tabular}{|c|c|c|c|c|c|c|c|}
\hline & 1 & 2 & A & 3 & 4 & 5 & 6 \\
\hline \multirow{12}{*}{ 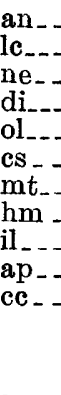 } & 4.03 & 7. 23 & & 0.83 & 25.30 & 36. 42 & 1. 39 \\
\hline & 1.80 & .44 & & 6. 54 & 1.31 & & 13. 95 \\
\hline & 10.79 & & - - & 15. 90 & 4. 54 & & 23. 28 \\
\hline & 21. 55 & 39. 07 & -- & 25. 49 & 47. 27 & 12.90 & 13. 61 \\
\hline & 7. 63 & 1. 57 &.- & 3. 92 & 4. 14 & 8. 69 & 5. 74 \\
\hline & 37.61 & 23. 39 & -- & 20. 12 & 12. 37 & 25.63 & 17. 53 \\
\hline & 6. 03 & 12.30 & -- & 9.51 & 3. 48 & 9.05 & 7. 19 \\
\hline & 1. 28 & $3-\overline{8}$ & - & 4. 16 & 106 & 0 & 1.44 \\
\hline & 1. 64 & $\begin{array}{l}0.00 \\
.67\end{array}$ & - & $\begin{array}{l}\text {.. } 31 \\
\text { 5. } 38\end{array}$ & $\begin{array}{l}.034 \\
.34\end{array}$ & & $\begin{array}{l}\text { 0. } 20 \\
\text { 3. } 70\end{array}$ \\
\hline & & & & & & & 1. 80 \\
\hline & $I^{\prime \prime} .2 .4^{\prime \prime}$ & IV.2.(2) & & IV.2.3.3 & "IV.1". & III(IV). & "III."9. \\
\hline & 4.2 & 3.3.2 & & (4).2(3) & 2.3.3. & 5.5.0. & $1^{\prime \prime} .4$ \\
\hline
\end{tabular}

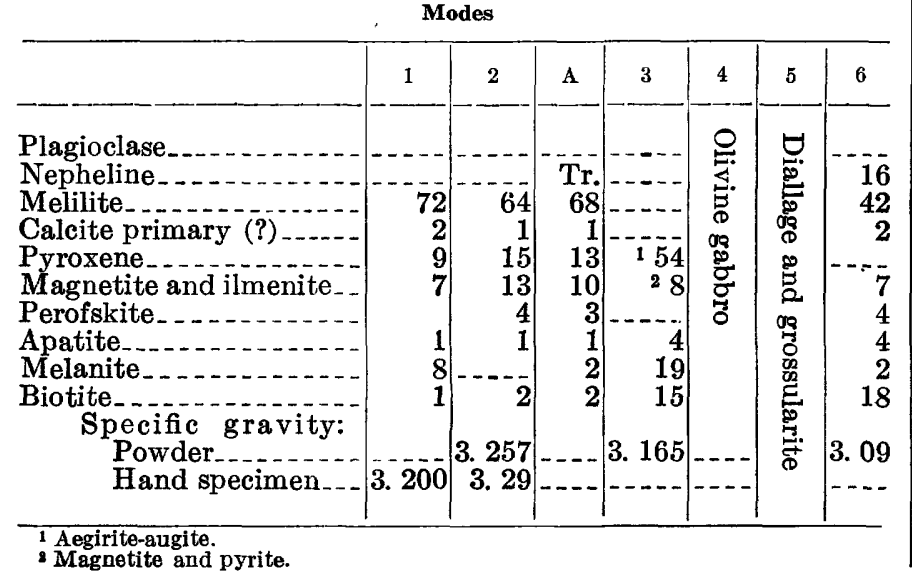

1. Coarse fresh uncompahgrite from south Beaver Creek, near granite contact (U-718). George Steiger, analyst. The nelilite is in cleavage pieces as much as 40 millimeters across and encloses poikilitically prisms of pyroxene and apatite and grains of the magnetite and perofskite as much as 3 millimeters across. The biotite grows about the magnetite. The calcite appears to be primary. The mode was determined by heavy liquid separations on a part of the analyzed powder.

2. Uncompahgrite, millimeter-grained (U-2015) from point east of Beaver Creek and 25 yards southeast of the mouth cf gully H. A few melilite grains are as large as 5 millimeters acro ss, and some pyroxene prisms are 10 millimeters long. The rock is fresh except for a very few veinlets of altered melilite. George $\$$ teiger, analyst.

A. Average composition of uncompahgrite of Iron Hill.

3. Cromaltite, Assynt, Scotland. A. Gemmell, analyst. Geol. Soc. Edinburg Trans., vol. 9, p. 417, 1910.

4. Olivine gabbro, Sohasahe, Madagascar. A. Lacroix, quoted from Washington, H. S., U. S. Geol. Survey Prof. Paper 99, p. 711, 1917.

5. Rodingite, Roding River, New Zealand. J. S. Maclaurin, analyst. Bell, J. M., New Zealand Geol. Survey Bull. 12 p. 32, 1911.

6. Turjaite, Turja, average of three analyses by Eskcla and Kranck. Fennia 51, p. 33, 1928.

\section{PYROXENITE}

\section{DISTRIBUTION AND AGE}

The pyroxenite underlies an area estimated as a little over 8 square miles, which is about two-thirds of the total area occupied by the Iron Hill complex including the marble, and 80 percent of the area occupied by the intrusive rocks of the Iron Hill complex. It makes up nearly all the exposures in the northern part, somewhat less in the Deldorado Creek drrinage area, and still less near the southern border of the complex. It borders the marble on the north, east: and south; but on the west alluvium borders the marble, and if the pyroxenite is present under the alluvium of Cebolla Creek, it must be narrower than elsewhare.

The pyroxenite intrudes the pre-Cambrian rosks in the drainage basin of Sammons Gulch, in the northern part of the area, for here several small dikelets of a fine-textured pyroxenite carrying some orthoclase cut the pre-Cambrian. It is believed to be younger than the marble of Iron Hill, as the contacts there se?m to be intrusive, and the numerous bodies of marble south of Beaver Creek are inclusions of a marble similar to that of Iron Hill. A small body of similar marble, on the crest of the ridge just south of Sammons Gulch and west of the lava cap, is an inclusion in the pyroxenite which sends many tiny dikelets across the marb]s. A section across the marble-pyroxenite contact that is exposed in an open cut is shown in figure 1 . The pyroxenite has everywhere metamorphosed the marble near the contact, and the inclusions south of Beaver Creek are to a considerable extent replaced by bintite, aegirite, phlogopite, and other minerals. The ryroxenite cuts the uncompahgrite. It is intruded ly all the other rocks of the area. 


\section{CHARACTER}

General features.- One of the most prominent characteristics of the pyroxenite is its variability: Almost any exposure a few feet long will show in different parts conspicuous differences in texture and to a less extent in the proportion of minerals. Less common bodies carry variable amounts of minerals not found in the normal rock. The different types are present in streaks, many of them less than a foot across, and in bunches mostly less than a few tens of feet across. Many of the variations show sharp contacts, and the different kinds of rock appear to intrude one another in a most complex way. Some of the streaks and many of the less regular bunches show a gradational zone, usually narrow, to the normal pyroxenite. Some idea of the character of the variation can be had from figures $2,3,4$, and 5 , which are rough sketches of the exposures in prospect pits, and plate $3, A$ and $B$, which are reproduced from photographs.

There is little evidence that the average rock varies over large areas, or that the pyroxenite varies on approaching either the siliceous granitic rocks or the marble, except in a very narrow zone. The northern part of the mass appears to be essentially like the southwestern or the southeastern part except that there may be a somewhat greater amount of nepheline rock in the southeastern part. In the southwestern area, where numerous bodies of limestone are included in the pyroxenite, primary(?) calcite appears to be common, and a titaniferous garnet takes the place of the perofskite.

In the finer-textured varieties of this rock the grains average less than a millimeter across, and in the coarser varieties they average 50 millimeters in length. Some of the rocks are exen-grained, but most of the coarser varieties are not, and crystals of pyroxene 40 millimeters long and 10 millimeters across are common. The pyroxene crystals are commonly arranged nearly parallel and across the banding of the rock. In some places the streaks of coarse and fine grains are sharply separated; in others they are gradational.

Common pyroxenite.-By far the greater part of the pyroxenite is made up of the minerals pyroxene, biotite, apatite, magnetite, and perofskite; and the most abundant and also the average rock contains about 60 percent of pyroxene, 15 percent of biotite, 10 percent each of magnetite and perofskite, and less apatite and ilmenite. The proportions of these minerals vary greatly-from a rock made up almost entirely of pyroxene to one made up almost entirely of biotite or any of the other minerals. In general, the magnetite and perofskite tend to remain in nearly equal proportions, and the apatite, magnetite, perofskite, and biotite tend to be associated. In rare exposures the pyroxene has been partly altered to the green amphibole, magnesic hastingsite. This alteration began along the borders of the pyroxene grains, and in local streaks all of the pyroxene has been altered to a coarse amphibole. Rarely the perofskite has been altered to a white amorphous-looking material resembling leucoxene. In places the closely spaced fractures of the pyroxenite contain thin seams, a millimeter or so thick, made up of black magnesic hastingsite, calcite, and yellow sphene, which are hydrotbermal.

An analysis, norm, ánd mode of a fine-grained pyroxenite are given in column 1, table 7 (p. 20-21).

The pyroxenite varies in texture as well as in composition. An analysis of a specimen selected as typical coarse pyroxenite is shown in column 2 , table 7 . This rock is made up of subparallel prisms of dark-green pyroxene as much as 50 millimeters long and $1 \mathrm{C}$ millimeters thick, with a little biotite in plates 5 millimeters or less across. The pale-brown biotite tends to grow about the magnetite and perofskite. The calcite is interstitial and appears to be primary. A large hand specimen was ground for the analysis, and part of the powder was used for an estimation of the proportions of the minerals present by separating with an electromagnet and heavy solutions and examining the products under the microscope.

Apatite-rich rock.-The proportion of apatite in the otherwise normal pyroxenite is locally 30 percent or more, and local bunches associated with the iron ore are nearly pure apatite. Narrow veinlets, mostly less than 2 centimeters wide, of granular apatite with about 10 percent each of magnetite and perofskite, in places cut the pyroxenite across the layering.

Biotite rock.-The proportion of biotite reaches 98 percent in some bodies of the rock, and apatite tends to concentrate with the biotite rock. Sphene was found in small amounts in some of the biotite-rich rock. Part of the biotite rock is fine-grained and friable; part is coarse-grained. An analysis of a specimen of rather coarse-grained biotite rock is shown in column 3 , table 7, p. 20.

Magnetite-perofskite rock. ${ }^{16}$-Local dikelike or lenslike bodies of "iron ore," many of them 20 feet across: made up of nearly pure magnetite and perofskite, are rather common, scattered through the pyroxenite. These bodies in general have sharp contacts with the surrounding pyroxenite, but in part they grade into it through a narrow zone. They are commonly associated with much apatite and with coarsely crystalline biotite, and the border zones of these bodies may be rich in biotite. The purest of this "ore" is a coarse-grained irtimate mixture of magnetite and perofskite, with a little ilmenite, apatite, and biotite. The perofskite is present in the usual twinned, zoned crystals. The magnetite molds about the perofskite and in places cuts it. The ilmenite is in plates or stringers in the magnetite. A similar magnetite-perofskite rock from Brazil has been

16 Hussak, E., Ueber ein neues Perowskitvorkommen in Verbundung mit Mag neteisenstein von Catalão, Staat Goyaz, Brasilien: Nenes Jahrb., 1894, no. 2, pp. 297-300. 
described by Tröger. ${ }^{17}$ Some of the ore has much apatite, and part of it has abundant biotite. In the latter variety biotite makes up as much as half the rock and is in large crystals as much as 10 centimeters across, oriented in various directions and poikilitically enclosing the other constituents. The apatite molds about the magnetite and perofskite.

An analysis and mode of the black iron ore (U-2108) is shown in column 9 , table 7 .

An analysis and mode of the ore with large poikilitic biotites is shown in column 8 , table 7 .

Olivine rock.-Rocks carrying olivine were found at only a few places, chiefly in the area with included fragments of metamorphosed limestone, south of Iron Hill, but also in other areas. They occur in very small bodies, and some at least are in dikes a few inches to a foot or so across, cutting the other types of pyroxenite and the uncompahgrite. These rocks carry conspicuous biotite, and where olivine is abundant they have a little less granular appearance than the ordinary pyroxenite. They carry as much as 50 percent or more of olivine, partly clear and fresh and partly altered to serpentine. Its optical properties indicate a variety with about 10 to 20 percent molecularly of $2 \mathrm{FeO} \cdot \mathrm{SiO}_{2}$. It is commonly associated with primary interstitial calcite. Biotite is invariably present, and it commonly includes the olivine poikilitically. Magnetite and perofskite are abundant, and apatite occurs in about the usual amount. Pyroxene, which is like that of the pyroxenites, may be absent or present in considerable amounts; where present, it tends to grow about the olivine. Irregularly molded between the olivine grains are small bodies of fine-textured intergrowths of diopside and garnet or vesuvianite or of fibrous cebollite with some calcite and colorless mica, exactly like the common type of metamorphosed uncompahgrite of this area. It seems probable that this rock had a little interstitia melilite. It may be a hybrid rock. An analysis of a typical olivine pyroxenite is shown in column 4 , table 7 .

A single specimen collected between the forks of Beaver Creek, just south of North Beaver Creek and 100 yards northeast of gully I, is much like the ordinary mica pyroxenite but contains 5 percent of olivine. The rock is composed of grains about 2 millimeters in diameter and is made up of about 50 percent of pyroxene, 25 percent of pale biotite, 5 percent of olivine, and the usual magnetite, perofskite, and apatite. The olivine is commonly included in and closely associated with the biotite.

A specimen from the south slope of Beaver Creek west of gully B, at an altitude of about 8,700 feet, is a dark millimeter-grained iron ore made up of about half magnetite and perofskite, with the remainder pyroxene, olivine, apatite, and interstitial fine-grained pyroxene and colorless garnet.

17 Tröger, E., Alkaligesteine aus der Serra do Salitre im westlichen Minas Geraes, Brasilien: Centralbl. Mineralogie, 1928, Abt. A, p. 202.
Garnet pyroxenite.-A variety of the pyroxenite containing considerable titaniferous garnet and some primary(?) calcite was found in small amounts, clcsely associated with marble inclusions, in the area south of Beaver Creek and Iron Hill and rarely in other pleces. It is believed to be a hybrid rock due to the assimilation of marble by the pyroxenite, and so far as observed the calcite has not traveled more than a few feet from the inclusions. A single hand specimen may show the normal pyroxenite, the hybrid rock, and merble fragments.

This rock differs from the normal pyroxenite chiefly in that it contains titaniferous garnet in place of perofskite, and it contains a few percent of interstitial calcite. One of the rocks contains a little cancrinite in aggregates. Hornblende is present, though rare in the normal pyroxenite.

The garnet is in irregular grains, closely associated with oalcite and in places forming a rim like a reaction rim between the calcite and the pyroxene. Local,- it cuts across the pyroxene grains in tiny veinlets. In places, it borders and shows remnants of incompletely replaced perofskite. It is black in the hand specimen and dark red brown in sections. It has an index of refraction ranging from 1.94 to 1.98 , indicating frc $m 8$ to 17 percent of $\mathrm{TiO}_{2}$. The calcite is mostly in large interstitial grains, molding between crystals of apatite, garnet, and pyroxene. In small part, chiefly on the borders of large grains, it is intergrown with pyroxene in wormlike forms. In one specimen it is associated with cancrinite. The minerals are all fresh, and there is no fine-textured or secondary calcite. The calcite has almost the identical position in the rock that the feldspar has in the feldspar types. I can account for the calcite only in the following ways: (1) As the last mineral to crystallize from the magma; (2) completely replacing the last mineral to crystallize from the masma; (3) filling open spaces in the crystallized rock.

The only mineral that suggests itself as having been replaced by the calcite is nepheline, and so complete a replacement of nepheline by coarsely crystalline calcite without zeolites or sericite, and without alteration of the other minerals, is very different from anything: observed elsewhere in the area and seems highly improbable. However, the garnet associated with the calcite is nuch like that associated with the nepheline-bearing pyroxenite, and the cancrinite in one specimen might have been derived from nepheline. The idea that the pyroxenite has abundant cavities, such as those occupied by the calcite after consolidation, is contrary to experience and seems highly improbable. There seems to be no resson to suspect that the calcite and garnet replace an older mineral. Indeed, had I not started with a decided prejudice against igneous calcite, it would have been accepted as obvious that the calcite and garnet were the last minerals to crystallize from the magma. I see no reason to doubt the igneous origin of the calcite in these rocks. 
The close association of the calcite with marble inclusions indicates that the calcite was dissolved from the marble and that it travelled only a short distancemeasured by inches or at most by feet. This calcitegarnet variety of the pyroxenite is much like the nepheline variety described in the next section, and the two grade into each other in petrographic character.

Nepheline pyroxenite (melteigite).-A variety of the pyroxenite carrying more or less nepheline was found over a considerable area, near the syenite, on both sides of North Beaver Creek, and in less amount in other places in the Beaver Creek drainage basin, as well as along Deldorado Creek and near the contact with the pre-Cambrian rocks in the extreme northwestern part of the mass. It probably makes up 1 percent or less of the pyroxenite body. So far as could be determined, it grades into the normal pyroxenite. It is nearly everywhere rather fine-grained and in the hand specimen resembles the fine-grained pyroxenite but shows a little interstitial white or pale-pink altered nepheline and some crystals of pale-yellow sphene.

Conmonly, this nepheline-bearing pyroxenite is cut by veinlets of nearly pure nepheline, and in much of the North Beaver Creek area nepheline forms a network of closely spaced veinlets. A thin section across one of these veinlets shows that the nepheline spreads out from the veinlets into the pyroxenite.

Nepheline commonly makes up less than 10 percent of these rocks, though locally it makes up over 50 percent. It is interstitial. In many places it is completely altered to zeolites and calcite. In some places the zeolite is analcime, in others cancrinite or fibrous natrolite or a mixture of several zeolites. In one specimen the nepheline has altered to a mass of calcite carrying coarse plates of muscovite. There is little or no perofskite in these rocks, but the titanium is present in the titaniferous garnet and sphene, both of which are abundant. Calcite that may be primary is present in some of these rocks. The pyroxene is rather dark green, in contrast with the very pale brownish pyroxene of the normal pyroxenite.

A variety of this nepheline rock that looks like a dark mica schist, from the parallel arrangement of the mica, was found a quarter of a mile northwest of the forks of Beaver Creek, along the road up North Beaver Creek, at an altitude of 9,100 feet, and at several places on the north side of Deldorado Creek, north of the crest of Iron Hill. The rock is millimeter- to half-millimeter-grained and is made up of about 40 percent of greenish pyroxene, 20 percent of light-green or light-brown mica, 25 percent of nepheline, partly altered, and more or less apatite and brown garnet or sphene.

The nepheline of the pyroxenite on North Beaver Creek is partly in veinlike streaks as much as a foot across, and partly distributed irregularly in the pyroxenite. In this area the nepheline is best explained as due to injection, impregnation, and reaction on the normal pyroxenite by the ijolite magma. Some parts of the nepheline pyroxenite look like a normal igneous rock.

A specimen of the pyroxenite containing a little nepheline and sphene, collected between the forks of Beaver and North Beaver Creeks, 50 feet above the creek bed and on the east side of the gully west of gully L, was analyzed. (See column 7 , table $i$.) It has grains 2 millimeters in diameter and is made up chiefly of pale-green pyroxene with darker borders, considerable sphene, some apatite, and altered nepheline. The nepheline is altered to analcime, natrolite, and calcite. An analysis of a fresh millimeter-grained ijolite from the south end of the ridge between Peaver and North Beaver Creeks is shown in column 5, table 7.

Feldspar-nepheline rock (shonkinite).-Associated with the nepheline pyroxenites, and much less abundant, are rocks containing both nepheline and orthoclase, which is probably sodic, and less commonly albite. In some of these rocks the orthoclase forms large crystals as much as 50 millimeters across, enclosing the pyroxene poikilitically. These rocks contain abundant sphene but no garnet or perofskite.

A large hand specimen of this type with large poikilitic feldspar was crushed for analysis, and a part of the powder was used to determine the proportions of the minerals present by separating with heav'r solutions and examining the products with a microscope. Rosiwal estimates were also made on three large thin sections. The results in weight percentages are shown below and are surprisingly consistent considering the coarse texture of the rock. (See table 7, column 6.)

\begin{tabular}{|c|c|c|c|c|c|}
\hline - & $\underset{\mathbf{A}}{\text { Section }}$ & $\underset{B}{\text { Section }}$ & $\underset{\mathrm{C}}{\text { Section }}$ & $\begin{array}{c}\text { Total } \\
\text { and } \\
\text { average } \\
\text { of sec- } \\
\text { tions }\end{array}$ & Powder \\
\hline Size $_{-}$square millimeters_. - & 360 & 420 & 360 & 1,140 & \\
\hline $\begin{array}{l}\text { Feldspar } \\
\text { Altered nepheline }\end{array}$ & 28 & 22 & 28 & 26 & 20 \\
\hline 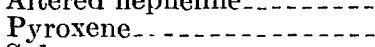 & 56 & 65 & 59 & 60 & 63 \\
\hline Sphene & 6 & 8 & 4 & 6 & 5 \\
\hline Apatite $_{\ldots} \ldots$ & 10 & 4 & 8 & 7 & \\
\hline Cálcite $\ldots$ & $\ldots \ldots$ & 1 & 1 & $2 / 3$ & $1 / 2$ \\
\hline
\end{tabular}

Feldspar-bearing rock.-A variety of the pyroxenite containing feldspar was found in small bodies in several places - as dikelike apophyses cutting the pre-Crmbrian along the northwestern border of the mass, in the upper drainage basin of gully $W$ near the $b c$ rder of the pyroxenite, in the drainage basin of Deldorado Creek east of gully $\mathrm{E}$, east of Iron Hill, and in the drainage basin of Beaver Creek east of gully $K$.

The body east of gully $\mathrm{K}$ is of considerable size and is associated with the nepheline pyroxenite. It makes up a small part of the pyroxenite mass. It consists chiefly of pyroxene with variable amounts of feldspar, 
apatite, and sphene, and a little magnetite. The feldspar is in some places untwinned potash feldspar, in others microcline or microperthite, and in still others albite.

The body of feldspar rock in gully $W$ is only a few feet across, is variable in texture and composition, grades into the normal pyroxenite, and is clearly a segregation. It reminds one of the pegmatitic segregations in granitic rocks. In part, over half of it is made up of white albite in crystals as much as several decimeters across, enclosing the apatite and pyroxene and filled with tiny needles of pyroxene. In other parts or no feldspar or nepheline but has considerable sphene, locally as much as 40 percent. In most specimens no garnet or perofskite is present in these rocks, but one specimen contains both sphene and perofskite. The sphene appears to be a late or a reaction mineral, as it fills in between the pyroxene crystals, bor ders the magnetite, and borders and replaces the perofskite where perofskite is still present. It is closely associated with the calcite and apatite. Interstitial calcite that is believed to be primary is present in some of these rocks, Biotite occurs in some of the rocks, and in some the pyroxene is partly altered to hornblende.

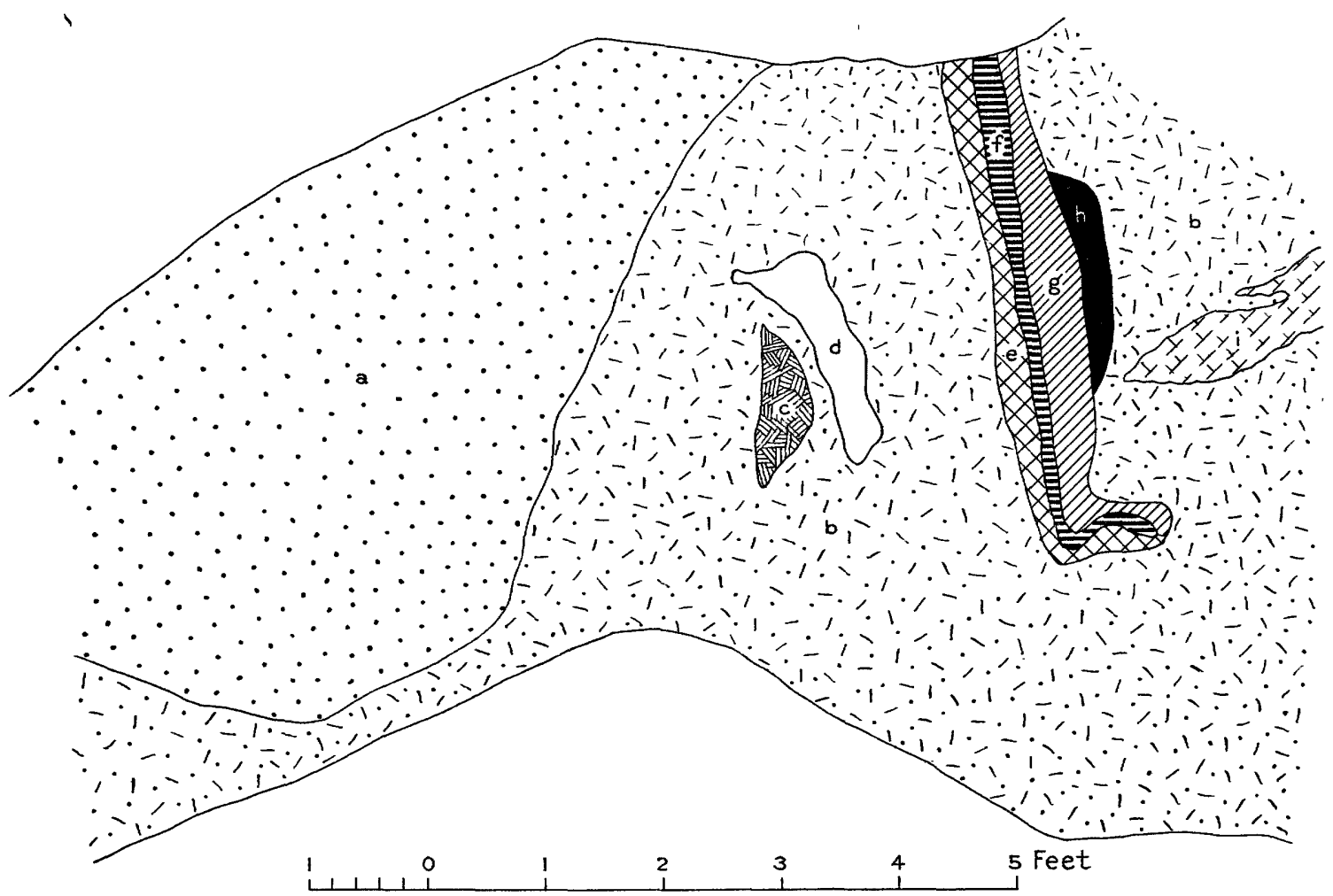

Figure 2.-Section south of Stone Gulch showing variation in pyroxenite. Portal of short tunnel 60 feet above the gulch and 0.6 mile east of the main wagor road up Cebolla Creek. For explanation see text.

coarse apatite takes the place of the feldspar and makes up nearly half of the rock. One specimen contains a little interstitial quartz. Sphene is present in small amount. The large pyroxene crystals are bright green only near the feldspar, the cores and grains away from the feldspar are the usual very pale olive gray.

The feldspar rock of Sammons Gulch, along the northwestern border of the mass, is much like the other feldspar rocks and is made up of microperthite, pyroxene, apatite, and sphene. The feldspar is irregularly distributed, in part in veinlike streaks. In general, the feldspar of these rocks is mostly albite, with only about 5 percent of anorthite. Microcline and untwinned potash feldspar are less abundant.

Sphene pyroxenite.-A variety of the pyroxenite, related to the nepheline- and feldspar-bearing rocks and closely associated with them in the field, contains little
An analysis and norm of a sphene-nephelite pyroxenite is shown in column 7 , table 7 .

\section{VARIATIONS IN THE PYROXENITE}

Natural exposures of the pyroxenite are poor, but they show that it is nowhere uniform over an area even a few feet across. It varies both in texture and in the proportion of its mineral constituents. A few prospects show the details of these variations; figures $2,3,4$, and 5 are sketches of faces exposed in open cuts. Pate $3, A$ and $B$, shows views of other cuts. The sketches are believed to represent fair samples of the pyroxenite although the prospectors naturally selected areas richer than usual in iron ore and they probably paid some attention to other unusual features. Lists of the minerals and textures of the rock varieties of the cuts are shown below and in tables 5 and 6 . 
In the cuts the following types are distinguished:

(a) Coarse-grained pyroxenite, which is probably the chief rock of the northern part of the pyroxenite mass. It is more or less layered or streaked with the fine pyroxenite parallel to the contact. Some layers are rich in biotite, and some layers and lenses consist of the fine pyroxenite. The large pyroxene crystals tend to be oriented with their long direction normal to the layers. Found in cuts shown in figures $2,3,4$, and 5 and plate $3, B$.

$\left(a^{\prime}\right)$ Coarse pyroxenite with pyroxene prisms oriented across the walls of the dikelet and with much mica. Found only in the (i) Nearly pure mica rock. Is sharply separated from the pyroxenite but has a ragged contact. Found only in the cut shown in figure 2.

(j) Intricately layered, parallel to the contact. If mostly fine pyroxenite (near that of type $b$ ) with streaks and layers of coarse rock near that of type $a$. Mica is present in noarly all the coarse-grained rock. Found only in the cut shown in figure 3.

(l) Over half olivine with interstitial idocrase and diopside, much perofskite, some opaque ore, and apatite. A smell bunch in the mica rock of cut shown in figure 5.

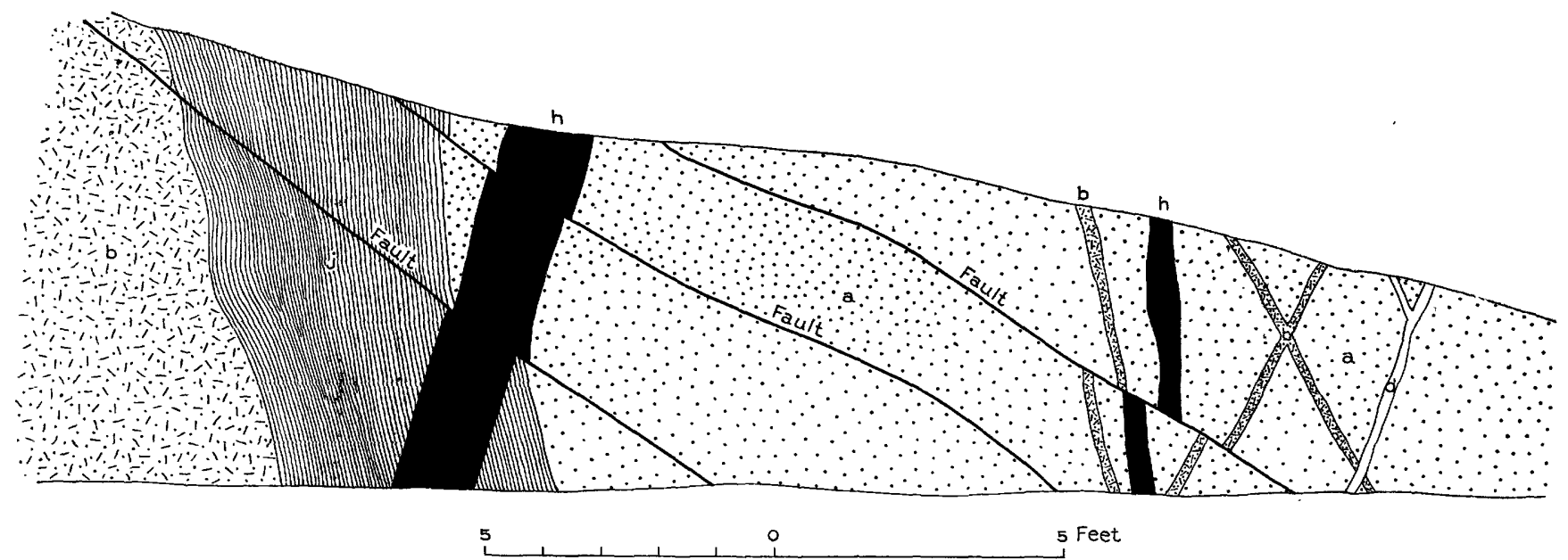

FrguRe 3. - Section on north side of Stone Gulch showing variation in pyroxenite. Along open cut 100 feet above the bottom of the gulch and 0.6 mile abova the road up Cebolla Creek. For explanation see text.

cut shown in figure 4, where they cut all the other rocks, including the iron ore.

(b) Fine pyroxenite cuts the coarse pyroxenite of type $a$, partly in veins with sharp contacts. Found in all the cuts. In the cut shown in figure 5 it is associated with seams and bunches of idocrase rock.

(c) A medium-grained rock rich in biotite. Found only in the cut shown in figure 2 and plate $3, B$.

(d) Similar to $b$ but has more mica and is friable. Found in the cuts shown in figures 2,3 , and 5 , it intrudes the pyroxenite of type $b$ with a sharp contact.

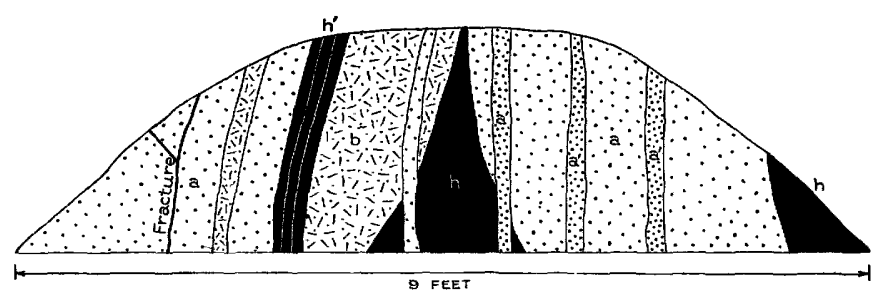

Figdrn 4.-Section south of Deldorado Creek showing variation in pyroxenite. Prospect half a mile east of fork northeast of Iron Hill. For explanation see text.

(e) Similar to type $b$ but friable and rich in apatite. Found in cuts shown in figures 2 and 5 .

$(f)$ A streak very rich in apatite. Its contacts are rather sharp, and it has the appearance of a dike or vein. Found only in the cut shown in figure 2.

(g) Coarse mica rock. Found in cuts shown in figures 2 and 5 and plate $3, A$.

(h) Iron ore. Cuts the coarse and fine pyroxenite in dikelike bodies. Found in cuts shown in figures 2, 3, and 4 .

$\left(h^{\prime}\right)$ Three seams of iron ore separated by thin layers of mica. Found only in cut shown in figure 4. (m) Altered uncompahgrite, now idocrase-diopside rock. Found only in the cut shown in figure 5.

$\left(m^{\prime}\right)$ A seam 1 to 2 inches thick of idocrase-diopside rock that appears to cut all the other rocks. It has a margin of coarse biotite. Found only in the cut shown in figure 5.

(n) Altered zone rich in vermiculite, calcite, etc. Fcund only in the cut shown in figure 5.

(o) A fine-grained rock made up mostly of garnet (melanite) with considerable biotite, a little calcite, apatite, and pyroxene. A small bunch in the cut shown in figure 5 .

TABLE 5.-Comparison of rocks of figure 2 [Percentages of constituents are only approximate]

\begin{tabular}{|c|c|c|c|c|c|c|}
\hline Constituents & $\begin{array}{c}\text { Grain size } \\
\text { (millimeter) }\end{array}$ & $\begin{array}{c}\text { Pyrox- } \\
\text { ene }\end{array}$ & Biotite & $\begin{array}{l}\text { Mag- } \\
\text { netite }\end{array}$ & $\begin{array}{l}\text { Perof- } \\
\text { skite }\end{array}$ & Apatite \\
\hline 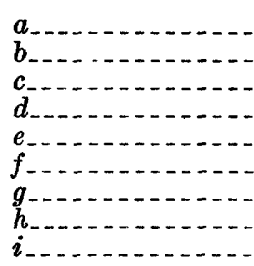 & $\begin{array}{c}19-20 \\
1 / 2-1 \\
1-2 \\
1 \\
1 \\
1 / 2 \\
20-1 \\
2 \\
10-1\end{array}$ & $\begin{array}{r}75 \\
80 \\
55 \\
50 \\
65 \\
0 \\
\text { Little } \\
2 \\
2\end{array}$ & $\begin{array}{r}18 \\
3 \\
33 \\
34 \\
10 \\
2 \\
93 \\
5 \\
97\end{array}$ & $\begin{array}{c}3 \\
10 \\
2 \\
2 \\
3 \\
8 \\
40^{1 / 2}\end{array}$ & $\begin{array}{r}3 \\
7 \\
2 \\
2 \\
2 \\
15 \\
1 \\
51\end{array}$ & $\begin{array}{c}1 \\
\text { Little } \\
8 \\
12 \\
20 \\
75 \\
5 \\
2 \\
1 / 2\end{array}$ \\
\hline
\end{tabular}

TABLE 6.-Comparison of rocks of figure 3

[Percentages of constituents are only approximate]

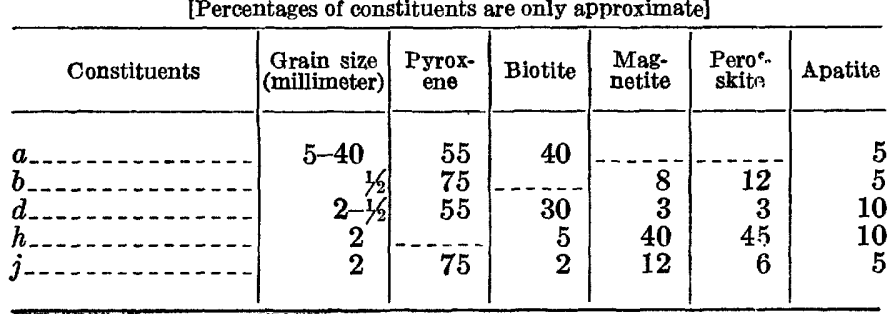



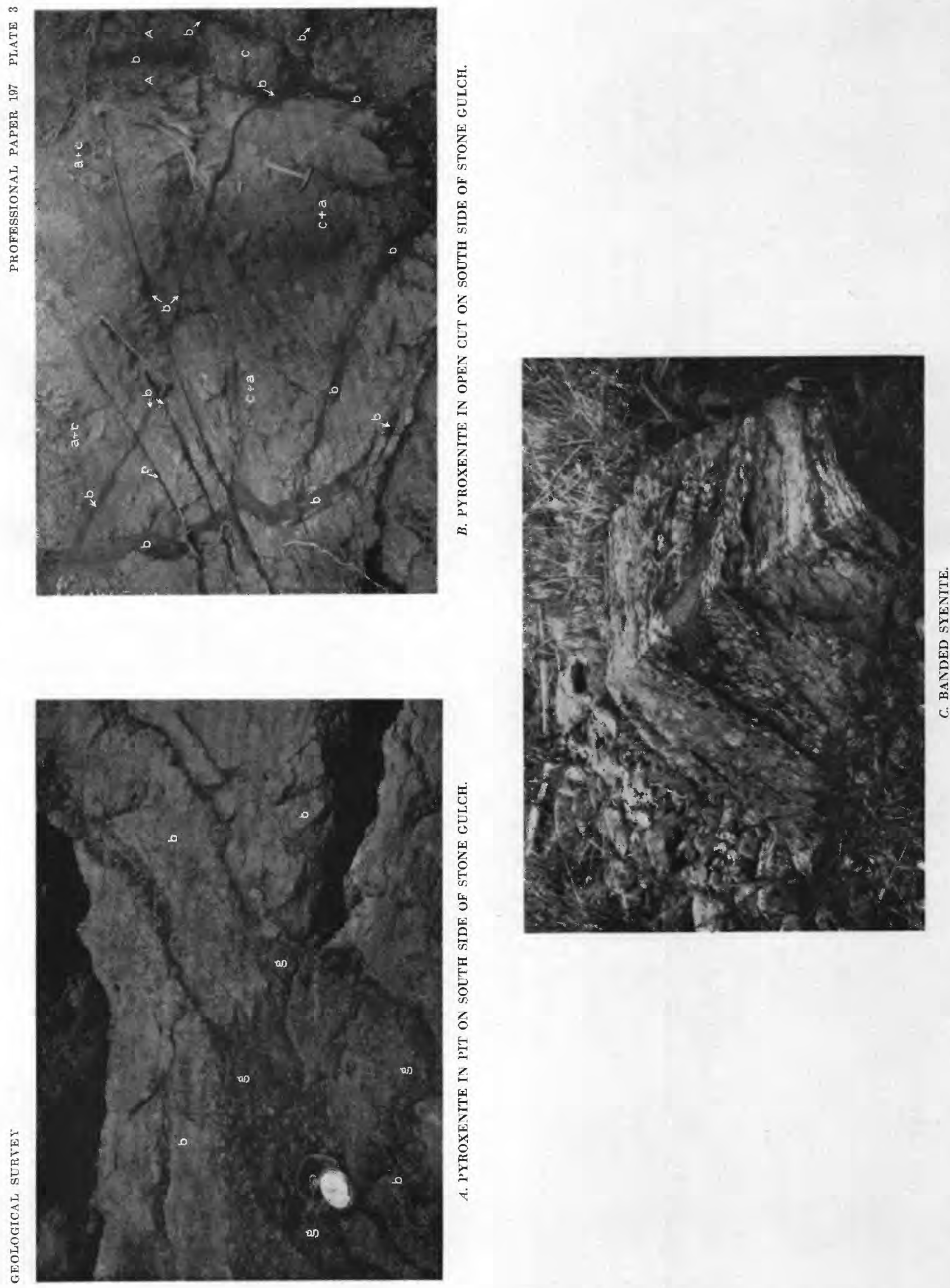


\section{ORDER OF CRYSTALLIZATION AND INTRUSION OF THE VARIETIES}

In the common types of pyroxenite pyroxene was the first mineral to crystallize, and its precipitation was nearly complete before any appreciable amount of the other constituents had crystallized. The magnetite and perofskite are molded between the pyroxene crystals and are later. The biotite encloses poikilitically the magnetite and perofskite, grows out from them, and is clearly later. The apatite appears to be associated most closely with the biotite and is in part later than the main biotite, which is cut by streaks of it.

There is a close similarity between the order of crystallization and the order of intrusion of the different varieties as shown in the cuts and other exposures. The earliest intrusive in the cuts is the coarse pyroxenite, which is mostly pyroxene with some mica and little of the other constituents. It was followed by the finegrained pyroxenite, which has less mica and more of the ore minerals. This was followed by mica-rich varieties, richer in apatite and associated with thin bodies of nearly pure apatite. The magnetite-perofskite ore is later than the fine-grained pyroxenite and is associated with the apatite-mica rocks, but its relation to them is not clear. In the open cut shown in figure 4 small seams of coarse mica pyroxenite cut the iron ore.

In the cuts figured and in most other places the contacts between the different types are sharp and look like intrusive contacts, mostly dikelike in form; in some places gradational contacts were seen.

\section{ORIGIN OF THE VARIETIES}

For the successive mineralogic varieties, the explanation seems obvious that after crystallization had proceeded far enough for open fractures to form, the residual liquid was collected into these cracks, and that this process was repeated several times. Whether this liquid was separated from the nearby mass of rock or at some depth is uncertain, although the common sharp "intrusive" contacts seem to indicate some movement of the magma and not a simple collection of the residual liquid from the partly crystallized rock in to adjoining cracks. The intimate relations between the different varieties of the rock may indicate separation of the liquid at no great distance from the present rock.

The magnetite-perofskite rock cuts the pyroxenite, the mica pyroxenites, and the mica rock. Some of the podlike masses that are associated with mica and apatite and grade into the normal pyroxenite resemble the segregation pegmatites, and they are believed to be segregations of the last residual liquid of the magma. The dikelike bodies are mostly only a few inches across. They are nearly pure magnetite-perofskite-apatite rock, have sharp contacts, and cut across the other varieties of the pyroxenites as small dikes. They are true intrusive dikes. Osborne ${ }^{18}$ states that the titanifer-

\footnotetext{
${ }^{18}$ Osborne, F. F., Certain magmatic titaniferous iron ores and their origin; Econ. Geology, vol. 23, p. 920, 1928.
}

ous magnetitess in anorthosite and gabbro are sharply bounded against the host rock, and that they were intruded into host rock after it had become solid.

In the nepheline rocks the nepheline was about the last mineral to crystallize. Some of the nepheline rocks look like uniform and normal igneous rocks, but most bodies are very irregular and are cut by innumerable closely spaced veinlets of nearly pure nepheline. Some of these veinlets have rather clean-cut walls, but many merge into the nepheline pyroxenite. The pyroxene near the nepheline is green, but away from nepheline and in the center of larger crystals it is the normal greenish gray, showing a reaction zone. The rock has all the appearance of a hybrid rock formed by the injection and impregnation of the pyroxenite by a highly fluid nephelinerich magma. The relations might also be explained as due to the segregation of a nepheline-rich part of the pyroxenite and a concentrate of the residual nepheline liquid in numerous veinlets cutting the nepheline-rich rock, but this explanation does not seem to fit the appearance and field relations of much of the nepheline pyroxenite. The distribution of the nepheline pyroxenite in a few rather large areas is such as would be expected from outside injection rather than segregation.

The garnet- and calcitebearing pyroxenite bodies are chiefly very near limestone inclusions. The garnet and calcite are interstitial minerals and the garnet borders pyroxene and has replaced perofskite. They,appear to be due to reaction with limestone inclusions.

Garnet and calcite also appear in some of the nepheline pyroxenites. Here too they are late minerals.

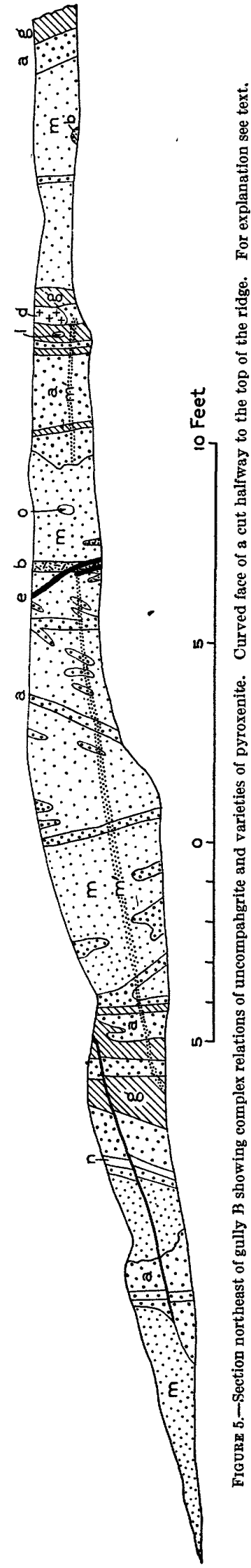
政 
In some specimens they are later than the sphene, which is itself one of the late minerals.

The feldspar has much the same relation to the other minerals as the nepheline except that feldspar veinlets are very rare, and the feldspar varieties appear to grade into the normal pyroxenites or form fairly uniform bodies. They are probably segregations in the pyroxenite. Some of them resemble the pegmatitic segregations in some granitic rocks.

The olivine-bearing rocks occur as small dikelike bodies cutting the normal pyroxenite. The olivine was the earliest mineral to form, and it is in places surrounded by pyroxene. These olivine rocks are probably later intrusives, less closely related to the pyroxenite than the other varieties.

\section{CHEMICAL ANALYSES, NORMS, AND MODES}

Nine analyses of the different varieties of the pyroxenite mass have been made, and their chemical composition, norms, and modes are shown in table 7. The corresponding data for similar rocks from Libby, Mont., and from Brazil are given for comparison. The Iron Hill rocks show a wide variation in both mineral and chemical composition. Probably the most striking chemical characteristics of the rocks are the high lime and titania and low alumina. The silica is low to very low; the titania is high to very high; the total iron is high; the magnesia is high except in the ores, and in the olivine rock it is very high. The lime is very high in all the rocks except the olivine rock, in which it is high. The alkalies are low even in the nepheline rocks, though potash is rather high in the biotite rock. The phosphate is rather high but is variable.

The relation between chemical composition and mineral composition is clear. The pyroxenites carry about 40 percent of silica, the nepheline and feldspar rocks somewhat more, the biotite-rich rocks less, and the ores very little. The titania is present criefly in the perofskite, less in the ilmenite, to a small extent in the melanite, biotite, and sphene, and slightly in the pyroxene. The alumina is very low in the pyroxene and is present mainly in the biotite, feldsp?r, and nepheline. The iron is mostly in the magnetite and ilmenite, and partly in the pyroxene and biotite. The magnesia is chiefly in the pyroxene and biotite and in the olivine only in the rare olivine rock. The lime is chiefly in the pyroxene, but in the ores it is in the perofskite and apatite. The soda is chiefly in the feldspar and nepheline; the potash chiefly in the biotite and less in the feldspar and nepheline.

The Iron Hill pyroxenites are much like the pyroxenites from Libby, Mont., but contain a little more titania and less phosphate. The biotite rocks of Libby are altered and hence have a low potash content and much water. The pyroxenites of Iron Hill are much like the jacupirangite from Brazil (analysis 12) but are poorer in alumina.

TABLE 7.-Chemical analyses, norms, and modes of rocks from the pyroxenite mass and related rocks

Analyses

\begin{tabular}{|c|c|c|c|c|c|c|c|c|c|c|c|c|c|c|}
\hline & 1 & 2 & 3 & 4 & 5 & 6 & 7 & 8 & 9 & 10 & 11 & 11a & 12 & 13 \\
\hline $\mathrm{O}_{2}$ & 40.25 & 36.82 & 22.02 & 31.28 & 47.88 & 47. 10 & 43. 50 & 8. 43 & 0.99 & 37.47 & 41.0 & 44.68 & 38. 38 & 35.7 \\
\hline $\mathrm{TiO}_{2}$ & $\begin{array}{l}4.76 \\
274\end{array}$ & $\begin{array}{l}9.02 \\
2.90\end{array}$ & $\begin{array}{r}8.79 \\
180\end{array}$ & $\begin{array}{l}6.60 \\
518\end{array}$ & $\begin{array}{r}.32 \\
834\end{array}$ & $\begin{array}{l}1.70 \\
8.16\end{array}$ & $\begin{array}{l}5.35 \\
3.97\end{array}$ & $\begin{array}{l}24.74 \\
74\end{array}$ & $\begin{array}{r}35.05 \\
280\end{array}$ & $\begin{array}{l}1.07 \\
2.86\end{array}$ & 18.0 & $\begin{array}{r}1.62 \\
15,23\end{array}$ & $\begin{array}{l}4.32 \\
6.15\end{array}$ & 7.4 \\
\hline$-\mathrm{Fe}_{2} \mathrm{O}$ & $\begin{array}{r}2.74 \\
10.83\end{array}$ & 8. 32 & $\begin{array}{r}10.80 \\
8.82\end{array}$ & $\begin{array}{l}\text { i. } 18 \\
\text { 12. }\end{array}$ & $\begin{array}{l}8.34 \\
3.27\end{array}$ & $\begin{array}{l}8.16 \\
6.38\end{array}$ & $\begin{array}{l}3.97 \\
3.42\end{array}$ & $\begin{array}{r}19.74 \\
16\end{array}$ & $\begin{array}{r}24.03 \\
\end{array}$ & $\begin{array}{r}2.80 \\
11.77\end{array}$ & $\begin{array}{c}18.0 \\
7.0\end{array}$ & $\begin{array}{l}5.91 \\
5.25\end{array}$ & $\begin{array}{l}\text { b. } 10 \\
11.70\end{array}$ & $\begin{array}{l}4.1 \\
9.4\end{array}$ \\
\hline $\mathrm{FeO}_{-}$ & 7. 38 & 6.18 & 6. 44 & 5.44 & $\begin{array}{l}0.83 \\
3.83\end{array}$ & 6. 62 & 4. 41 & 13.68 & 14.26 & 7.83 & 7.0 & 2.78 & 8.14 & 6.9 \\
\hline $\begin{array}{l}\text { Mno } \\
\text { MgO- }\end{array}$ & $\begin{array}{r}.16 \\
1204\end{array}$ & $\begin{array}{l}.06 \\
11.68\end{array}$ & $\begin{array}{r}.15 \\
13.02\end{array}$ & $\begin{array}{r}.06 \\
23.15\end{array}$ & $\begin{array}{r}.18 \\
9.50\end{array}$ & $\begin{array}{l}.36 \\
\text { 3. } 97\end{array}$ & $\begin{array}{r}.19 \\
8.12\end{array}$ & $\begin{array}{r}.26 \\
5.06\end{array}$ & $\begin{array}{l}.24 \\
1.90\end{array}$ & $\begin{array}{r}.16 \\
10.12\end{array}$ & 21.0 & 15.53 & $\begin{array}{r}.16 \\
11.47\end{array}$ & 11.10 \\
\hline $\mathrm{CaO}$ & 20.21 & $\begin{array}{l}11.08 \\
21.38\end{array}$ & 13. 58 & $\begin{array}{l}10.26 \\
10\end{array}$ & 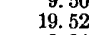 & 17.30 & 24.69 & $\begin{array}{r}1.00 \\
19.98\end{array}$ & 19.86 & 21.68 & 1.0 & $\begin{array}{r}4.82 \\
4.82\end{array}$ & $\begin{array}{l}11.67 \\
18.60\end{array}$ & $\begin{array}{l}19.7 \\
\end{array}$ \\
\hline $\begin{array}{l}\mathrm{N}_{2} \mathrm{O}_{2} \\
\mathbf{K}_{2} \mathrm{O}\end{array}$ & $\begin{array}{r}.42 \\
\text { None }\end{array}$ & $\begin{array}{l}.68 \\
.45\end{array}$ & $\begin{array}{r}.70 \\
4.75\end{array}$ & $\begin{array}{r}.25 \\
1.88\end{array}$ & $\begin{array}{l}3.84 \\
1.70\end{array}$ & $\begin{array}{l}\begin{array}{l}3.15 \\
2.15\end{array}\end{array}$ & $\begin{array}{r}1.55 \\
.14\end{array}$ & $\begin{array}{l}.35 \\
.59\end{array}$ & & $\begin{array}{l}.47 \\
.93\end{array}$ & 1.0 & $\begin{array}{r}.45 \\
2.63\end{array}$ & $\begin{array}{l}.78 \\
.13\end{array}$ & $\begin{array}{r}.6 \\
1.9\end{array}$ \\
\hline $\mathrm{H}_{2} \mathrm{O}-$ & $\begin{array}{r}.46 \\
46\end{array}$ & 53 & 1.51 & & & & .34 & .35 & .39 & .27 & 11.0 & 1.50 & .18 & .4 \\
\hline - & .46 & $\begin{array}{l}.53 \\
\text { None }\end{array}$ & $\begin{array}{l}2.70 \\
6.35\end{array}$ & 3. .03 & $\begin{array}{l}1.42 \\
1.45\end{array}$ & $\begin{array}{l}1.10 \\
1.49\end{array}$ & $\begin{array}{l}.58 \\
3.11\end{array}$ & $\begin{array}{l}.65 \\
5.58\end{array}$ & $\begin{array}{l}37 \\
.58\end{array}$ & 4.33 & & $\begin{array}{l}1.94 \\
2.01\end{array}$ & .17 & $\begin{array}{l}.9 \\
1.3\end{array}$ \\
\hline 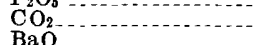 & .07 & 1.34 & & & & & & None & .08 & .06 & & .07 & None & .2 \\
\hline $\begin{array}{l}\text { Sau } \\
\text { Sro }\end{array}$ & Tr. & $\begin{array}{l}.08 \\
.06\end{array}$ & .48 & $\begin{array}{r}.04 \\
.02\end{array}$ & $\cdots$ & $\begin{array}{l}.05 \\
\text { None }\end{array}$ & $\begin{array}{l}\text { None } \\
.13\end{array}$ & $\begin{array}{l}.05 \\
.12\end{array}$ & .06 & .06 & & $\begin{array}{l}.07 \\
.10\end{array}$ & & $\begin{array}{r}05 \\
.05\end{array}$ \\
\hline 知 & & .31 & & .24 & .05 & .07 & & None & & & & & & .1 \\
\hline$F_{-}-$ & None & .10 & .02 & .04 & & .25 & .03 & $\begin{array}{r}.04 \\
.19\end{array}$ & .01 & $\begin{array}{l}.04 \\
.36\end{array}$ & & $\begin{array}{l}.05 \\
.14\end{array}$ & & .1 \\
\hline $\mathrm{V}_{2} \mathrm{O}_{3}$ & ${ }_{.04}^{T r}$ & & .03 & & & & & $\begin{array}{l}\text { None } \\
.20\end{array}$ & .06 & .12 & & .06 & & Tr. \\
\hline & None & & .01 & & & & None & None & & & & .04 & & Tr. \\
\hline $\begin{array}{l}\mathrm{ZrO}_{2} \\
\mathrm{NiO}\end{array}$ & None & . & .02 & (n............. & . & (n.......... & $\begin{array}{l}\text { None } \\
\text { None }\end{array}$ & .01 & & None & & .07 & & Tr. \\
\hline \multirow{3}{*}{ Less $\mathrm{O}$ for $\mathrm{F}$ and $\mathrm{Cl}_{-}$} & 100.32 & 99.91 & 100.47 & & 100.30 & 99.85 & 100.19 & 100.23 & 100.68 & 100.47 & & & 78 & 1000 \\
\hline & & .04 & .08 & .02 & & .10 & & .18 & & .15 & & .10 & & \\
\hline & & 99.87 & 100.39 & 99.78 & & 99.75 & & 100.05 & & 100.32 & $\ldots$ & 99.80 & & ..... \\
\hline
\end{tabular}


ALKALIC ROCKS OF IRON HILL, GUNNISON COUNTY, COLO.

TABLE 7.-Chemical analyses, norms, and modes of rocks from the pyroxenite mass and related rocis-Continued

Norms

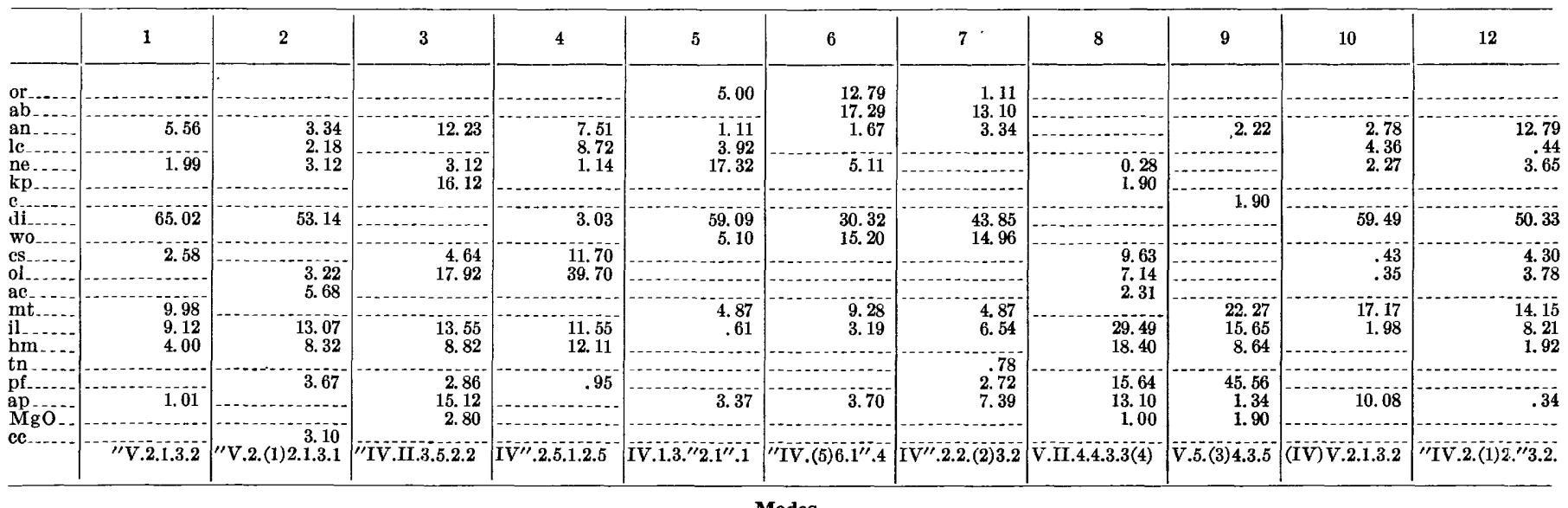

\begin{tabular}{|c|c|c|c|c|c|c|c|c|c|c|c|c|c|}
\hline & 1 & 2 & 3 & 4 & 5 & 6 & 7 & 8 & $\dot{9}$ & 10 & 11 & 12 & 13 \\
\hline $\begin{array}{l}\text { Orthorlase } \\
\text { Albite }\end{array}$ & & & & & & 20 & & & & & & & $\begin{array}{l}\text { Tr. } \\
\text { Tr. }\end{array}$ \\
\hline Nepheline..... & & & & & 19 & 8 & 6 & & & & & Little & Tr. \\
\hline Diopside & 76 & 72 & & 12 & 77 & 63 & 79 & 6 & & 74 & & Chief & 61 \\
\hline Biotite & $-\cdots$ & 5 & 64 & 15 & $-\cdots$ & $\cdots$ & - $-1 . . .-1$ & 9 & $\cdots$ & 5 & $\begin{array}{r}98 \pm \\
\text { Altered }\end{array}$ & (n-.... & $\begin{array}{r}15 \\
\text { Tr. }\end{array}$ \\
\hline Melanite & & & & $\begin{array}{r}34 \\
-\end{array}$ & & & & & & 1 & & & $\begin{array}{l}\text { Tr. } \\
\text { Tr. }\end{array}$ \\
\hline $\begin{array}{l}\text { Apatite } \\
\text { Perofskite....... }\end{array}$ & $\begin{array}{l}1 \\
6\end{array}$ & Tr. & $\begin{array}{r}15 \\
9\end{array}$ & 8 & 4 & 4 & 7 & $\begin{array}{l}13 \\
34\end{array}$ & $\begin{array}{r}1 \\
50\end{array}$ & 10 & $2 \pm$ & Tr. & \\
\hline Magnetite.... & 17 & 12 & 11 & 19 & $\mathrm{Tr}$ & Tr. & & 27 & 41 & & & Much & 11 \\
\hline $\begin{array}{l}\text { Ilmenite } \\
\text { Sphene }\end{array}$ & ? & $\mathrm{Tr}$ & 11 & \{ & IT. & Tr. & 8 & 11 & 8 & Little & & Much & ${ }^{3}{ }^{3}$. \\
\hline Carbonate (primary) & - & 3 & $\ldots$ & - n & -.... & Tr. & & -..- & 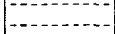 & Little & $\cdots$ & & ${ }^{T} r_{i}$ \\
\hline Amphibole (secondary) & - n....... & $1 / 2$ & - n-..... & & -..- & & & -...... & $-\ldots$ & & & & $\ldots$ \\
\hline Altered melilite (?) & -......... & & -........ & 12 & & & & -.............. & & & & & \\
\hline $\begin{array}{l}\text { Specific gravity: } \\
\text { Hand specimen }\end{array}$ & 3.616 & 3.514 & 3. 203 & 3. 293 & 3.198 & 2.965 & & 3.973 & & & & & \\
\hline Powder specimen & & & 3. 386 & & & & 3.298 & & 4.335 & 3.417 & 2.30 & & \\
\hline
\end{tabular}

1. Fine-grained pyroxenite (U-1199). Prospect on south bank of Stone Gulch about 0.6 mile above its mouth. Rosiwal determination on five slides aggregating 1,000 square millimeters gave rather variable results, averaging as shown in the first column below. A determination of the minerals on the powder used in the analyses gave the results shown in the second column.

\begin{tabular}{l|r|r}
\hline & Sections & \multicolumn{1}{|c}{ Powder } \\
\hline Pyroxene & 68 & 76 \\
Magnetite and ilmenite & 16 & 17 \\
Perofskite & 9 & 6 \\
Apatite & 7 & 1 \\
\hline
\end{tabular}

The grain size is commonly between 1 and 0.5 millimeter. The magnetite and perofskite are molded between the pyroxene grains. The perofskite is partly in separate grains and partly intergrown with the magnetite. This rock type makes up nearly half the mass. George Steiger, analyst.

2. Coarse pyroxenite (IH-101). North slope of south fork of Deldorado Creek 200 yards above main creek. The determinnation of the minerals was made on part of the powder used in the analysis by separation in heavy solution. Some of the pyroxene prisms are 50 millimeters long and 10 millimeters thick; the other constituents range from 1 to 5 millimeters across. Pale-brown biotite tends to grow about magnetite and perofskite; some carbonate appears to be primary and interstitial. This type makes up nearly half the mass. F. A. Gonyer, analyst.

3. Biotite rock (biotitite) (U-1975). South of Beaver Creek, on the ridge between gullies $\mathrm{A}$ and $\mathrm{B}$, just below the talus slopes. The biotite plates are nearly all less than 5 millimeters across.
Mineral composition determined by separation in heavy solution on part of the powder used for the chemical analyses. Biotiterich rock makes up little of the mass, but some biotite is present in much of the mass. George Steiger, analyst.

4. Olivine pyroxenite (IH-325). South of Beaver Creek, north fork of gully $A$, about half a mile above the road in Cekolla Valley. Biotite in grains as much as 2 millimeters across, mo'ded between and enclosing other constituents; olivine and pyrorene in grains averaging about 1 millimeter; magnetite and perofskite in somewhat smaller grains, either between the pyroxene and olivine or embedded in the biotite. Melilite interstitial and altered to cebollite and idocrase-diopside mixture. Rosiwal determination on two large thin sections aggregating 1,100 square millimeters. Found in a few small dikes. Analyzed by F. A. Gonyer.

5. Nepheline pyroxenite (melteigite) (U-1877). Ridge between North Beaver Creek and gulley $N$, just above alluvium at south end of ridge. Proportion of minerals determined on part of analyzed powder by separation in heavy liquid (column 2) and on two thin sections totaling 780 square millimeters (column 1).

\begin{tabular}{|c|c|c|}
\hline & 1 & 2 \\
\hline $\begin{array}{l}\text { Nepheline } \\
\text { Pyroxene. } \\
\text { Apatite }\end{array}$ & $\begin{array}{c}21 \\
751 / 2 \\
3\end{array}$ & $\begin{array}{r}19 \\
77 \\
4\end{array}$ \\
\hline
\end{tabular}

The pyroxene prisms are rarely over 1 millimeter long and average somewhat less; the nepheline is interstitial and as much as $\mathbf{2}$ millimeters wide. This rock makes up a small part of the mass and may be either a variety of the ijolite, a rock transiticnal 
between the pyroxenite and ijolite, or the result of the soaking of the pyroxenite by the ijolite magma. Analyzed by F. A. Gonyer.

6. Feldspar-nepheline pyroxenite (shonkinite) (U-2138). Between Beaver and North Beaver Creeks on the ridge west of gully $\mathrm{L}$, just north of the cap of lava. A nearly black rock that at first glance looks to be about millimeter-grained but on close examination is seen to be made up of glassy feldspar with prominent cleavages about 40 millimeters across in which are included prisms of dark-green pyroxene a few millimeters long and about a millimeter thick. Rosiwal determinations on three thin sections aggregating 1,140 square millimeters gave surprisingly consistent results and checked with the estimate by heavy liquids on the analyzed powder within 3 percent on all the minerals. This rock makes a very small part of the pyroxenite body. Analyzed by F. A. Gonyer.

7. Sphene-nepheline pyroxenite (melteigite) (U-2133). South of North Beaver Creek, east side of the small gulley which is west of gulley $\mathrm{L}$ and 50 feet in altitude above North Beaver Creek. The mode was estimated on a thin section. The rock has a grain size of about 1 millimeter. Some of the pyroxene rods are 2 millimeters long. The nepheline, which is altered to fibrous natrolite, is molded between the pyroxene grains. Makes very little of the mass. Analyzed by George Steiger.

8. Biotite-magnetite-perofskite rock (U-1192). Prospect pit in south fork of Sammons Gulch 100 yards west of granitepyroxenite "contact. Mode determined by heavy liquid and magnetic separation of part of the analyzed powder. Found as small dikelike bodies that make up little of the mass. The rock has biotite in cleavage flakes as much as several centimeters across, apatite crystals several millimeters long, and crystals of magnetite and perofskite, embedded in the mica and apatite, mostly about a millimeter across. Analyzed by George Steiger.

9. Magnetite-perofskite rock (U-2108). Prospect on north side of Stone Gulch half a mile above road. Mode determined on three thin sections. Made up of crystals of perofskite averaging about 1 millimeter across embedded in a matrix of magnetite with some ilmenite. Found in many small dikelike bodies and makes up little of the pyroxenite mass. Analyzed by George Steiger.

10. Pyroxenite from Libby, Mont. Analyzed by George Steiger.

11. Biotite rock (altered to vermiculite and sold as zonolite). Large mass in pyroxenite of Libby, Mont. Quoted from an address by E. N. Alley, of Zonolite Company, Libby, Mont., delivered on January 3, 1930 at Butte, Mont. Personal communication from Mr. Alley.

11a. Biotite pyroxenite, Libby, Mont. Kindly furnished by Dr. A. Holmes. Analysis by Imperial Chemical Institute, Research Department, Bellingham, County Durham, England.

12. Jacupirangite, Jacupiranga, Brazil. H. S. Washington, analyst. The rock from Magnet Cove, Ark., is very similar.

13. Average of the Iron Hill pyroxenite as estimated from the proportions of the types present in the mass.

\section{IJOLITE (MELTEIGITE) DISTRIBUTION}

Mafic rocks miade up chiefly of nepheline, pyroxene, and garnet intrude the unconpahgrite and pyroxenite in many places. Some of these bodies are clean-cut dikes, and others are larger and less regular. The largest underlies an area of about 0.1 square mile and lies west of South Beaver Creek and just south of the main forks of Beaver Creek; two others are to the east, across South Beaver Creek; another lies between North Beaver Creek and fork $\mathrm{N}$; and several snialler bodies are niapped just north of Beaver Creek and west of the nuain forks. In the drainage basin of Deldorado Creek one small body is mapped just northwest of the mouth of fork B, two others across fork $B$ to the east, and a somewhat larger niass just north of the junction of forks $G$ and $H$.

These mapped bodies are nıade up of rock rery different from the pyroxenite, and they have, sharp, intrusive contacts with the pyroxenite. Besides the mapped bodies there are nuany smaller bodies of typical ijolite and some fairly large areas of rock that resenible the pyroxenite but contain variable amounts of nepheline, garnet, or titanite, ninerals clcsely associated with the nepheline. These nepheline-bearing pyroxenites are commonly cut by so very nuany tiny stringers of nepheline rock that alniost any slab a foot across will show several of thent.

The following are the chief places in which nephelinebearing rocks were found but not separated frons the pyroxenite:

(1) On the ridge northeast of gully $A$, several small bodies.

(2) At the upper part of the ridge between forks $\mathrm{B}$ and $\mathrm{C}$ of Beaver Creek.

(3) Northeast of the forks of gully $\mathbf{C}$.

(4) On the east slope of the hill surrounded by contour line 8,600 just east of fork $D$.

(5) Both west and east of fork L.

(6) At many places on the ridge between North Beaver Creek and fork $O$, especially north of North Beaver Creek near the syenite.

(7) At several places on the ridge east of Iron Hill.

(8) On the extreme south fork of Deldorado Creek near the syenite contact.

(9) At several places south of Sammons Gulch.

(10) In the ridge between fork $B$ of Deldorado Creek and Huntsman Gulch, and at some other places.

\section{PETROGRAPHY}

The ijolite of the nuapped bodies is for the most part a niedium- to coarse-grained rock. In places the grains are as coarse as 100 nillinieters, but mostly they are between 3 and 10 millimeters. Both the texture and the proportions of the minerals are highly variable. Nepheline, dark diopside, and black titaniferous garnet are the chief constituents; biotite is nowhere present in large aniount, though it is the chief or only dark mineral in sonie of the nepheline-rich rocks of the mass between North Beaver Creek and gully $O$. Primary(?) calcite is common but in small amount. Apatite occurs in considerable amounts, and the ores, magnetite and perofskite, are minor accessories. Sphene is not present in nost of the rocks but is abundant in sonie, especially the rocks with feldspar and those approaching the pyroxenite in texture and 
composition. Microcline was found in very few of the rocks. Wollastonite was found as an aggregate in a single specimen collected just above the road 0.2 mile northwest of the main forks of Beaver Creek. It is probably due to reaction with a limestone inclusion.

The following table gives some idea of the range over which the minerals vary and the approximate average proportions:

TABLE 8.-Approximate range in the mineral composition of the ijolite in percentages by weight

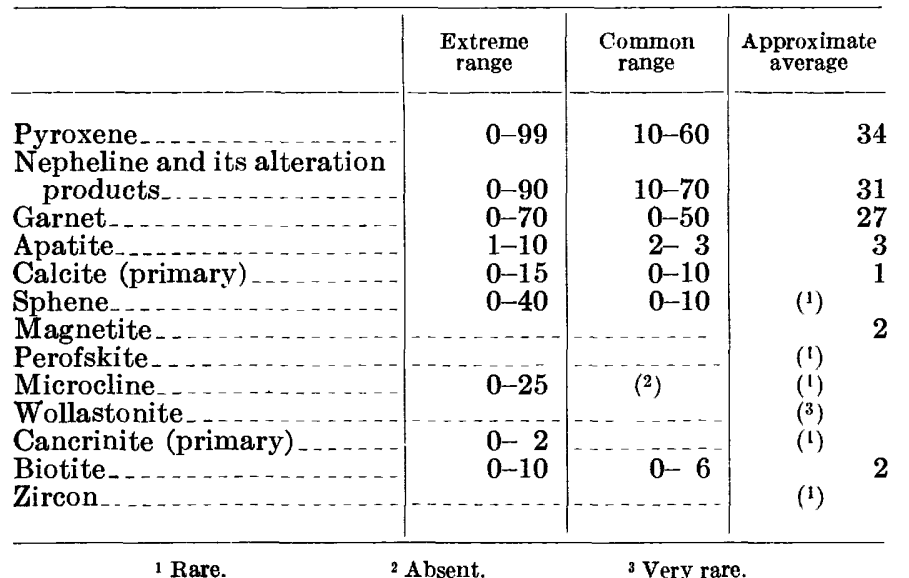

In accordance with Brögger's classification, ${ }^{19}$ hand specimens of the rocks included in ijolite on the map would range from urtite through ijolite and melteigite, on the one hand, to jacupirangite, to juvite and malignite on the other. The garnet-rich rocks, the sphenerich rocks, and the calcite rocks might be placed in another group if so refined a classification seemed desirable. As all the rocks are variants of single geologic bodies, it seems better to use the general name "ijolite," which applies to nearly all of them.

The pyroxene was the first mineral to crystallize, as it occurs in well-formed crystals embedded in the other minerals. It ranges from pale grayish to deep green, and commonly the core is gray like that of the pyroxenite, and the borders are green. All the varieties belong to the diopside-hedenbergite series, but the green variety contains a little aegirite. The details of their compositions are discussed in the section on mineralogy (pp. 45-48). For the most part the pyroxene is fresh, but rarely along sheeting planes a thin layer is altered to magnesic hastingsite. Locally this amphibole has replaced the pyroxene irregularly, and rarely the coarse amphibole has replaced much of the pyroxene.

The nepheline is molded about and encloses the pyroxene crystals. In places pieces of pure fresh nepheline 10 centimeters across can be collected; most of the nepheline-rich rock is coarse. In considerable part the nepheline is more or less altered to fibrous natrolite, analcime, or cancrinite with some calcite.

\footnotetext{
${ }^{10}$ Brögger, W. C., Das Fengebiet in Telemark, Norway: Vidensk, sẹlsk, Oslo Forh., 1920, No. 9, pp. 16-52.
}

Rarely it is altered to coarse aggregates of muscovite. In a very few specimens there is around the large pyroxene grains a zone made up of an intergrowth of the green pyroxene and nepheline somewhat resemblin; graphic intergrowths, and in one specimen these intergrowths project into the nepheline crystals in rounder embayments. These intergrowths resemble those of myrmekite.

The garnet is the dark titaniferous variety characteristic of the area, and it is more abundant in the ijolite than in any of the other rocks. It occurs in part in large irregular grains several centimeters across, in part in rims about the pyroxene, perofskite, magnetite, apatite, or even nepheline grains, and in part in irregular veinlets cutting the other minerals. The garnet is commonly associated with the primary (?) calcite and rather commonly forms a rim between pyroxene and calcite. In places it is intergrown with pyrite. As in all the other rocks of the area, the garnet appears to have crystallized in the transitional stage between the magmatic and hydrothermal periods.

Primary (?) calcite is common in the ijolites, usually in small amounts. It occurs as rather coarse grains, in part associated with the nepheline. Both are interstitial to the pyroxene and may be present as alternate grains in the streaks between pyroxene. There is commonly, but not everywhere, a narrow layer of cancrinite between the two. The calcite is probably later than the nepheline and earlier than the garnet, as is shown by the rims of garnet between pyroxene and calcite and the veinlets of garnet-cutting calcite.

Most of the biotite is pale green. It crystallized late, as it occurs chiefly in irregular layers on the ore minerals and is closely associated with the garnet.

Sphene is not common in the typical coarse-grained ijolite but it is abundant in some of the fine-grained nepheline pyroxenite. In some of the veinlets of coarse ijolite, sphene is abundant only near the pyroxenite contacts. It is not commonly associated with th $\mathrm{A}$ titaniferous garnet, but in a few specimens it is included in garnet. The feldspar-bearing rocks carry more sphene than those without feldspar.

Microcline is abundant as coarse crystals poikilitically enclosing pyroxene in some of the nepheline-bearing rocks from the area west of gully $L$ of Beaver Creek and from the ridge north of North Beaver Creek, west of the syenite mass, but it is an uncommon mineral in thee ijolite.

A fine-grained pyroxenite near the contact with the quartz porphyry in the south fork of Sammons Gulch contains a few percent each of plagioclase, nepheline, and sphene, as does also a specimen from the saddle between Huntsman Gulch and fork B of Deldorado Creek.

The order of crystallization is pyroxene, apatite, nepheline, calcite, biotite, cancrinite, garnet. 


\section{CHEMICAI ANALYSES, NORMS, AND MODES}

Four specimens of the fresh ijolite that were considered typical and one of a biotite variety in which the nepheline had been altered to analcime have been analyzed. The analyses, norms, and modes are given in table 9.

TABLE 9.-Analyses, norms, and modes of ijolite.

Analyses

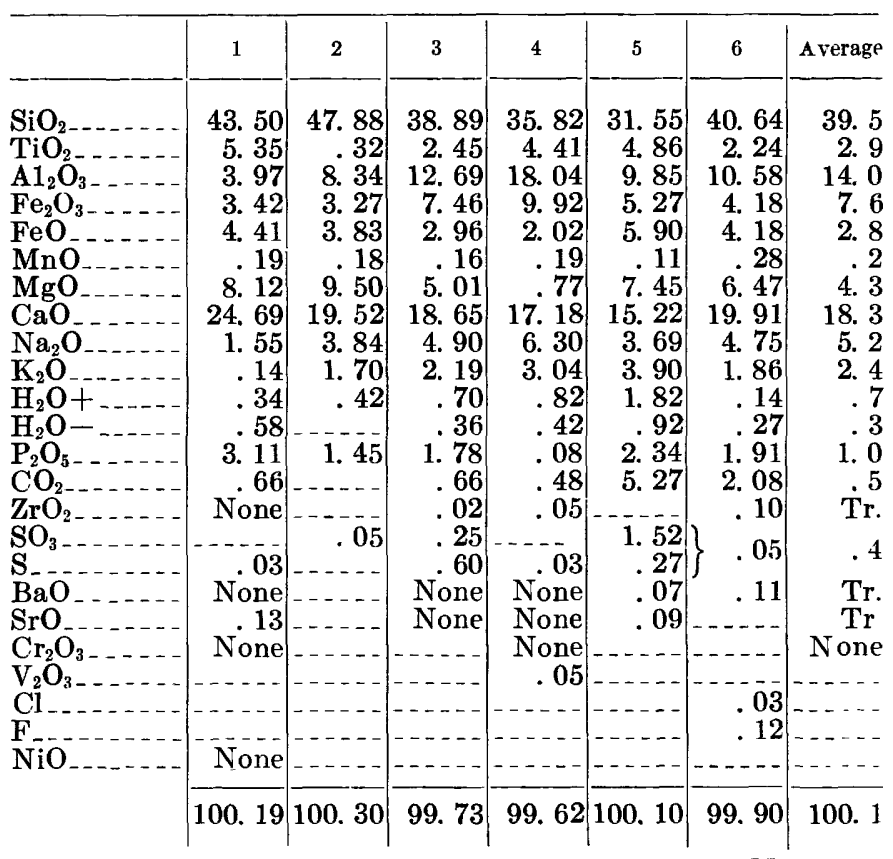

\begin{tabular}{|c|c|c|c|c|c|}
\hline \multicolumn{6}{|c|}{ Norms } \\
\hline & 1 & 2 & 3 & 4 & 6 \\
\hline ab. & 13. 10 & & & & \\
\hline or - & 1. 11 & 5. 00 & & & \\
\hline an & 3. 34 & $\begin{array}{l}1.11 \\
3\end{array} 92$ & $\begin{array}{r}6.39 \\
10\end{array}$ & 11.95 & 1. 95 \\
\hline $\begin{array}{l}\text { lc } c_{--} \\
\text {ne_- }\end{array}$ & $-\ldots$ & $\begin{array}{r}\text { 3. } 92 \\
\text { 17. } 32\end{array}$ & $\begin{array}{l}10.00 \\
22.44\end{array}$ & $\begin{array}{l}10.90 \\
28.97\end{array}$ & 21. 78 \\
\hline $\mathrm{di}_{-}$ & 43. 85 & 59.09 & 27. 00 & 4. 10 & 36. 72 \\
\hline wo & 14.96 & 5. 10 & 1.86 & 7. 08 & 10. 67 \\
\hline & & & 12.10 & 13. 76 & \\
\hline$m t$ & 4. 87 & 4. 87 & 2. 78 & & 6.03 \\
\hline 11 & 6.54 & .61 & $\begin{array}{l}4.71 \\
5,60\end{array}$ & $\begin{array}{lll}4 . & 71 \\
9 & 92\end{array}$ & 4.26 \\
\hline & 7. 39 & 3. 36 & 4. 37 & & 4. 37 \\
\hline & 2. 72 & & & 3.26 & \\
\hline & & & & & 4. 70 \\
\hline & $\begin{array}{r}I^{\prime \prime} . \dot{2} .2 \\
\quad(2) 3.2\end{array}$ & $3 . " 3.1$ " & $\begin{array}{l}\text { III(IV). } \\
8^{\prime \prime} . " 2.4\end{array}$ & III 8.2 .4 & "IV.2.1.2. \\
\hline
\end{tabular}

\begin{tabular}{|c|c|c|c|c|c|c|}
\hline \multicolumn{7}{|c|}{ Modes } \\
\hline & 1 & 2 & 3 & 4 & .6 & A verage \\
\hline $\begin{array}{l}\text { Nepheline } \\
\text { Diopside } \\
\text { Dioft. }\end{array}$ & $\begin{array}{r}6 \\
79\end{array}$ & $\begin{array}{l}19 \\
77\end{array}$ & $\begin{array}{l}28 \\
38\end{array}$ & $\begin{array}{r}39 \\
8\end{array}$ & $\begin{array}{l}27 \\
47\end{array}$ & $\begin{array}{l}31 \\
34\end{array}$ \\
\hline $\begin{array}{l}\text { Biotite } \\
\text { Melanite }\end{array}$ & & & 2 & 2 & 6 & 2 \\
\hline Magnetite and il- & & & & & & \\
\hline $\begin{array}{l}\text { menite-... } \\
\text { merofflite }\end{array}$ & $T r$ & $\mathrm{Tr}$. & $T r$ & & 432 & \\
\hline Apatite & & 4 & $r_{4}$ & 3 & 5 & \\
\hline $\begin{array}{l}\text { Calcite } \\
\text { Microl }\end{array}$ & & & 1 & 1 & 5 & \\
\hline $\begin{array}{l}\text { Mirerolite } \\
\text { Sphene }\end{array}$ & & & & & 1 & $\mathrm{Tr}$ \\
\hline Specific gravity: & & & & & & \\
\hline speci- & 3. 298 & & & & 3. 10 & \\
\hline & & 198 & 22 & & & \\
\hline
\end{tabular}

1. Sphene-nepheline pyroxenite (ijolite) (U-2133). West of gully $\mathrm{O}, \mathbf{0 . 2}$ mile above its junction with North Beaver Creek, just above alluvium. The mode was estimated on a thin section. The rock has a grain size of about 1 millimeter. Some of the pyroxene rods are 2 millimeters long. The nepheline, which is altered to fibrous natrolite, is molded between the pyroxene grains. Analysis by George Steiger.

2. Pyroxene ijolite (U-1877). Ridge between Nowth Beaver Creek and gully N, at south point of ridge. Proportions of the minerals determined on part of the analyzed powder. The pyroxene prisms are rarely over 1 millimeter long and average somewhat less; the nepheline is interstitial and rarely over 2 millimeters across. The rock may have been formed by soaking of the pyroxenite by the melteigite magma. Analyzed by F. A. Gonyer.

3. Pyroxene-melanite ijolite (U-1132). South of North Beaver Creek 0.1 mile above mouth of gully I. Grairs from 1 to 4 millimeters across. Mode determined on part of powder used for analysis. Analyzed by George Steiger.

4. Melanite ijolite (U-2011). One-third mile south of forks of Beaver Creek. Grains of nepheline as much as 12 millimeters across; those of pyroxene as large as 10 by 3 millimeters, and garnet 10 millimeters or less across. Mode determined on part of powder used for analysis. Analyzed by George s'eeiger.

5. Altered biotite ijolite (U-1265). Easternmost outcrop on ridge south of gully $\mathrm{O}$ (North Beaver Creek). Geo"ge Steiger, analyst

6. Melteigite, Melteig, Fengebit, Norway. A. Rödland, analyst.

\section{CRYSTALIIZATION OF IJOLITE}

Bowen ${ }^{20}$ has discussed the crystallization of rocks that have the composition of mixtures of nepl oline and

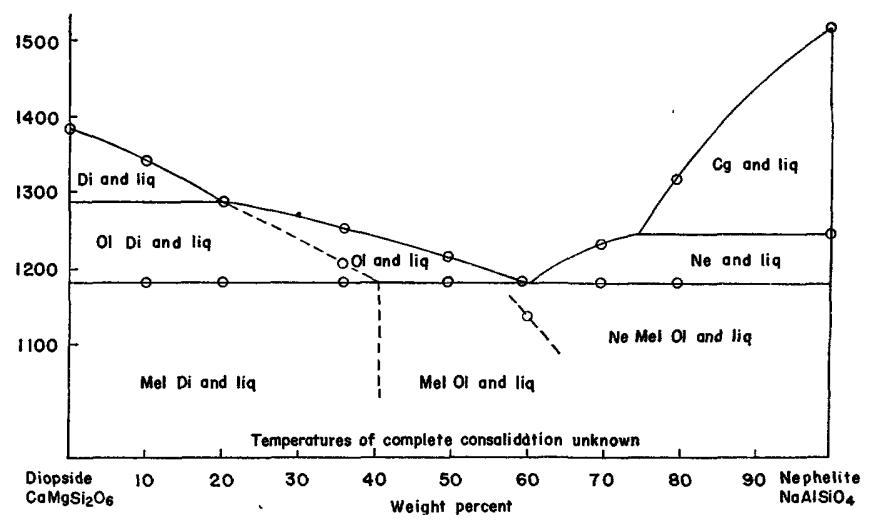

FIGURE 6.-Pseudobinary diagram of equilibrium in mixtures of nepheline and diopside.

diopside and has worked out experimentally a pseudobinary diagram of equilibrium in mixtures of nepheline and diopside. This diagram is reproduced in figure 6 . It does not carry the crystallization below about $1,100^{\circ}$ as crystallization at lower temperatures was too sluggish for the determination of equilibrium.

Many of the Iron Hill ijolites are nearly pure nepheline-diopside rocks and they range from nearly pure diopside to rocks with 90 percent of nepheline. In the garnet-free rocks they carry only a few percert of other minerals, chiefly.apatite, magnetite, and calcite. The

${ }^{20}$ Bowen, N. L., Genetic features of the alnoitic rocks at Isle Calieux, Quebec: Am. Jour. Sci., 5th ser., vol. 3, pp. 1-33, 1922; The evolution of the igneous rocks, pp. 260-268, Princeton Univ Press, 1928. 
natural nepheline has not the same composition as the theoretical nepheline used by Bowen and the natural diopside has some hedenbergite in solid solution. One of the analyzed rocks had in the mode 19 percent of nepheline and 77 percent of augite, and in the norm 17 percent of nepheline, 4 percent of leucite, and 59 percent of diopside. These rocks, therefore, approach in chemical composition the mixtures of Bowen's equilibrium diagram about as closely as any group of rocks approach any of the equilibrium diagrams that have been worked out in the laboratory.

In the Iron Hill rocks neither olivine nor melilite is present in any of the ijolites, and nothing was seen to indicate that they were once formed. The rocks are coarsely crystalline and probably cooled very slowly and had time for equilibrium. It is possible that the iron, the mineralizers, and the other differences between the natural and the artificial systems materially changed the equilibrium relations. This seems rather probable, for we have good reason to believe that the temperature of intrusion and crystallization of the ijolites was much below $1,100^{\circ}$.

If the ijolites crystallized in the manner indicated by Bowen's diagram, there must have been reactions below about $1,100^{\circ}$ that resulted in the final solidification of the system to diopside and nepheline. In that event, for rocks rich in diopside the course of crystallization would have been first diopside alone, and later olivine and diopside simultaneously; at some temperature below $1,200^{\circ}$ the olivine was reacted on and melilite precipitated until all the olivine was dissolved; then melilite and diopside crystallized together; finally the melilite was reacted on and nepheline precipitated until all the melilite was gone. For rocks with about equal amounts of nepheline and diopside, such as the common variety of the ijolite, the course of crystallization would be olivine first, then olivine and melilite, then the dissolving of olivine and melilite and the deposition of nepheline and diopside.

There is nothing in the rocks to suggest the early formation of olivine or melilite. The rocks are made up chiefly of well-formed crystals of diopside and nepheline grains molded one against the other.

In these coarse-grained rocks all evidence of the early generation of olivine and melilite might have been destroyed, but that is not likely in the effusive types of pyroxene-nepheline rocks, the nephelinites. It seems probable that most of the natural rocks that are made up in large part of nepheline and diopside crystallized directly as nepheline and diopside, except for minor reactions.

\section{SODA SYENITE}

The largest body of soda syenite underlies the hills between Deldorado and Beaver Creeks, near the northeastern border of the Iron Hill stock. This body underlies an area of about 0.12 square mile. Four smaller bodies are present along the southern boundary of the Iron Hill stock-two just east of South Beaver Creek and two to the west. Another mapped body intrudes limestone and pyroxenite just east of the road up Cebolla Creek and half a mile south of Beaver Creek. A rather large dike cuts the pyroxenite south of Ncrth Beaver Creek between gullies $J$ and K. Several small dikes are mapped in the drainage area of Sammons Gulch near the northwestern nose of the Iron Hill stock. A few small unmapped outcrops of this syenite were found in the drainage area of Deldorado Creek and elsewhere within the stock, and several dikelike bodies cut the older granites that surround the Iron Hill stock and outside the area included in the Iron Hill map. Such bodies were found near the top of the mesa at the head of North Beaver Creek, west of Cebolla Creek opposite the mouth of Deldorado Creek, west of Cebolla Hot Springs, near the mouth of Milkranch Gulch, and on the ridge south of Milkranch Gulch at an altitude of about 8,300 feet.

Farther from the Iron Hill stock and outside the area shown on plate 1 , similar syenites are less commnn. They were found near the Lot mine, east of Willow Creek, under the peak with an altitude of 10,200 feet, a third of a mile northwest of Carpenter Hill, on the east side of Goose Creek below Dubois, and elsewhere. The total area underlain by this syenite is about C.14 square mile.

The contacts of the syenite are mainly intrusive, but between Beaver and Deldorado Creeks and on both sides of South Beaver Creek there is a narrow zone of crushed rock with some calcite, quartz, and manganese oxides or iron oxide between the syenite and the granite. Along the contact of the syenite with the granite south of Beaver Creek there is some evidence of movement. In many places near the contact with the granite the syenite is granulated and banded, indicating some movement. In part the fractures are healed by the primary minerals of the syenite but in part by hydrothermal aegirite and soda amphibole. There was probably little movement along these fractures, and that must have taken place before the syenite was completely crystallized. The soda syenite intrudes the pyroxenite $\varepsilon$ nd ijolite and is cut by dikes of the nepheline syenite.

The common syenite and the rock that makes up nearly all of the large body between Beaver and Deldorado Creeks is light gray and streaked or even prominently laminated and gneissoid. It is commonly fine-textured, especially in the more laminated rocks, but some of the less well-banded rocks have feldsyar crystals as much as several centimeters across ir. a finer matrix. Rare rocks are centimeter-grained or coarser and without lamination or streaking.

Perthite makes up about 90 percent of most of the rocks. It is in grains ranging from 0.5 millimeter to 1 centimeter in cross section. In the banded rocks it is in rather uniformly small grains, but in the streaked rocks 
the grains are variable in size. On the average albite is somewhat more plentiful than microcline, but the proportion varies greatly. Where the microcline is present in large amount the albite is in a network of veinlets cutting across the microcline and in narrow, irregular rims about the microcline. Where the microcline is present in smaller amount the albite veinlets and borders are wider, and the microcline forms rounded islands embedded in albite. The albite appears to have partly replaced the microcline.

The dark mineral of this syenite is a dark-green aegirite-diopside. It makes up the dark streaks and bands, and in thin sections veinlets of pyroxene grains cut across the feldspar. In the well-laminated rocks these veinlets are subparallel, but in many of the rocks they are oriented in various positions and form a network. The pyroxene grains are nearly all less than 1 millimeter long. The pyroxene makes up on the average about 9 percent of the rocks.

Apatite and sphene are widely occurring but not abundant accessories; zircon is very rare; fluorite is rather common; and quartz was found in only a single specimen, which also contained sericite, fluorite, and carbonate. Sericite and carbonate are common secondary products in the syenite. Rarely aegirite and an amphibole related to glaucophane, are the dark minerals. They are secondary and occur chiefly along fractures.

The rocks of the small bodies along the south border of the Iron Hill stock are like well-banded, gneissoid varieties of the mass just described. The pyroxene makes the dark streaks; biotite streaks are less common, and streaks of sericite are present. The dikes just south of Sammons Gulch and east of the wagon road are also of this type.

These rocks have been mashed and granulated. Microcline or perthite crystallized before the granulation, and pyroxene and albite with some mica after the granulation. This granulation probably took place during the injection and crystallization of the syenite, as neither the earlier pyroxenite nor the later nepheline syenite shows such granulation. A photograph of a block of syenite from South Beaver Creek near the granite contact that has rather extreme banding is reproduced in plate $3, C$.

It is uncertain whether the pyroxene and albite crystallized directly from the magma or are deuteric, but a deuteric or very late magmatic origin seems more probable. Nearly everywhere the pyroxene is in bands, and in part it is in veinlike streaks that may cut across feldspar grains. The amount of pyroxene tends to be very high in the banded syenite. The albite certainly appears to have replaced the microcline, and in some specimens only remnants of the microcline remain. The amount of albite is highly variable, and where albite is abundant a "sea and island" texture is common. The small amount of liquid interstitial to the original microcline crystals could not have fur- nished the albite (soda) to replace so large an amount of microcline, and the potash of the original microcline must have been removed from the rock.

The rock of the mass just east of Cebolla Creek and south of Beaver Creek is not banded, but it commonly has the dark minerals concentrated in veinlike streaks, many of which are curved. Near the limestone contacts the dark minerals are especially abundant and the streaks well developed. The rocks are made up mostly of perthite with albite predominating. Calcite is commonly present in small amount. The chief dark mineral is an amphibole related to glaucophene, but there is some phlogopite and locally aegirite. These minerals are the common hydrothermal minerals of the area, and they are hydrothermal here.

The body south of Milkranch Gulch is very similar and is also associated with marble. Some parts of this body contain quartz. Nearly all the other small bodies in the granitic rocks surrounding the Iron Hill stock are of this type, with varying proportions of the different dark minerals.

A chemical analysis of the typical syenite (U-1206a) south of gully $\mathrm{N}$ and near the northwest base of the hill surrounded by the 9,000-foot contour wes made by George Steiger and is shown below.

TABLE 10.-Analysis, norm, and mode of soda syenite

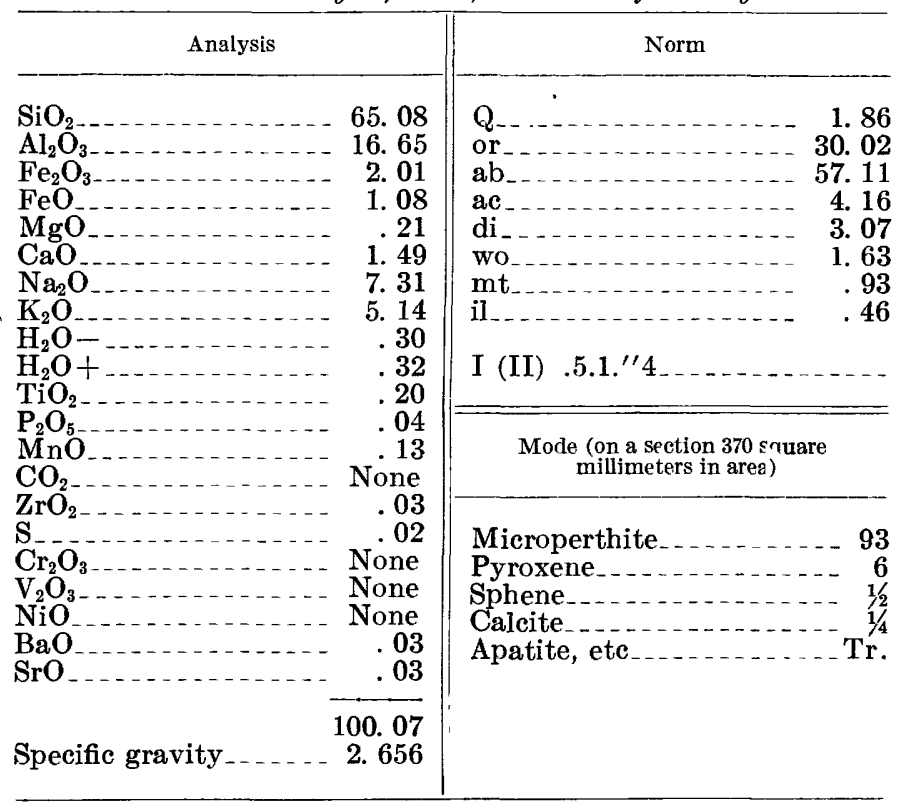

\section{NEPHELINE SYENITE}

Syenites containing nepheline or its alteration products are present chiefly in the drainage basins of Beaver and Deldorado Creeks between the pyroxenite or soda syenite and the older granitic rocks that surround the Iron Hill stock. The largest body extends from North Beaver Creek northwestward into the drainage basin of Deldorado Creek, with a narrow strip extending between the rocks of the Iron Hill stock and the older granites for about 2 miles to the west of the main body. The main body is about 1 mile long and half a mile wide. On both sides of fork $L$ of Beaver Creek many dikes of 
this syenite, for the most part only a few feet across, cut the pyroxenite, and fewer cut the bordering granitic rocks. The mapping of these dikes is much generalized, as the dikes are far too numerous to show on the scale of the map. In the northwestern nose of the stock and in many other places small dikes of this syenite cut the pyroxenite and other rocks of the Iron Hill complex and the surrounding older rocks. They are not all shown on the geologic map (pl. 1), especially those in the granites. At some distance from Iron Hill, beyond the boundaries of the area mapped in this report, such dikes were found (1) on the east rim of Cebolla Creek $1 \frac{3 / 4}{4}$ miles northeast of Tolvar Peak; (2) on the east rim of Cebolla Canyon northeast of Carpenter Hill; (3) on the east slope of Camp Creek N. $52^{\circ} \mathrm{E}$. from the knob at 8,900 feet, at an altitude of 8,700 feet; (4) south of Spencer; (5) on Willow Creek and elsewhere. The total area underlain by this nepheline syenite is about 0.5 square mile.

The nepheline syenite cuts the soda syenite and all the other rocks of the Iron Hill stock except the gabbros, and it is cut by dikes of both varieties of gabbro.

The nepheline syenite is rather uniform in character. It is a light-gray rock where fresh but flesh-colored to reddish brown where altered and is characterized by the tabular shape of its feldspar crystals. In thin sections and on the cleavage surfaces in hand specimens the feldspars appear to be lath-shaped and about four times as long as broad. Their length is commonly about 3 to 5 millimeters, but in some specimens it is over 10 millimeters and in others less than 2 millimeters. These feldspars show only a slight tendency to be arranged parallel to the flow direction.

The rock is made up of about 80 percent feldspar, with nepheline next in abundance, then aegirite, magnetite, biotite, sphene, apatite, and zircon, and in a few specimens a titaniferous garnet. The feldspar is microperthite, with more albite than microcline. A few specimens, notably those from the two dikes that cut the soda syenite north of fork $\mathrm{O}$ of North Beaver Creek, contain microcline with little intergrown albite. The microcline is clouded and occurs in streaks and islandlike bodies cut and surrounded by bays and channels of albite. The outer parts of the crystals and the interstitial feldspar are mostly albite.

Nepheline or its alteration products makes up from a few percent to 15 percent of the rocks. It is interstitial to the feldspar. It is mostly altered, and the chief alteration product is cancrinite. A part of the cancrinite may be primary, but much of it is secondary. Analcine is abundant in some parts; natrolite and other zeolites are not common. In some specimens the nepheline is altered to sericite much like the nepheline of Libby, Mont. ${ }^{21}$

${ }^{21}$ Larsen, E. S., and Pardee, J. T., The stock of alkaline rocks near Libby, Mont.: Jour. Geology, vol. 37, pp. 107-108, 1929.
The dark mincrals and accessories are irregulerly distributed, and they rarely make up much more tl an 6 percent of the rock. Aegirite is the chief of these and ranges from a trace to 5 percent. Biotite is the chief dark mineral in some of the rocks, but it is absont in many. Brown titaniferous garnet $(n=1.93)$ ras found only in a few small patches. In these patches it may make up 10 percent or more of the rock. It is interstitial and associated with nepheline. This garet may be due to reaction on an inclusion, but it seems to be a late magmatic mineral.

Magnetite is nearly as abundant as aegirite and in some specimens is the chief dark mineral. Sphene is commonly present but in small amount and is more or less clouded from alteration. Zircon is less common and is zoned and altered along some of the zones. One small outcrop of. unusually coarse syenite contains much nepheline (altered) and numerous brown crystals of zircon as much as 5 millimeters across. Apatite is present in small amount. A few of the syenite specimens, notably those with microcline feldspar instead of perthite, contain a little interstitial calcite that appears primary.

Some of the small veins of syenite are porphyritic, with millimeter phenocrysts of tabular feldspar, in fluidal arrangement, making up nearly half the rock. The groundmass is much altered, very fine-grained and is made up of aegirite in ragged crystals of varial ${ }^{1} e$ size, with feldspar, altered nepheline, and secondary calcite.

An anlaysis of the typical gray nepheline syenite made by George Steiger and the norm and mode cre shown below. The analyzed rock is fresh except that the nepheline is altered to cancrinite.

TABLE 11.-Analysis, norm, and mode of nepheline syerite (specimen $U-1481$ )

\begin{tabular}{|c|c|c|}
\hline Analysis & Norm & . \\
\hline 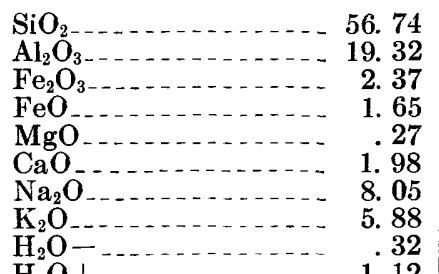 & 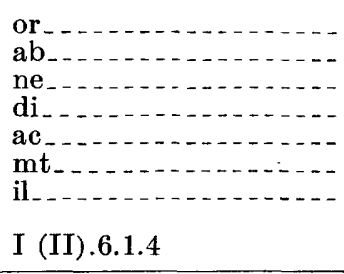 & $\begin{array}{r}\text { 35. } 03 \\
\text { 34. } 58 \\
17.32 \\
\text { 3. } 25 \\
\text { 1. } 39 \\
2.78 \\
.76\end{array}$ \\
\hline $\begin{array}{l}\mathrm{TiO}_{2 \ldots} \ldots \ldots \\
\mathrm{CO}_{2 \ldots} \ldots \ldots\end{array}$ & \multicolumn{2}{|l|}{ Mode } \\
\hline 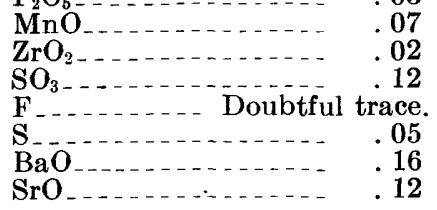 & $\begin{array}{l}\text { Perthite } \\
\text { Cancrinite from nephe- } \\
\text { line } \\
\text { Biotite } \\
\text { Magnetite } \\
\text { Aegirite } \\
\text { Calcite...... }\end{array}$ & $\begin{array}{l}83 \\
12 \\
1 \\
21 / 2 \\
1_{1 / 2}\end{array}$ \\
\hline $\begin{array}{c}\text { Specific gravity (hand } \\
\text { specimen) }\end{array}$ & & \\
\hline
\end{tabular}


SHORTER CONTRIBUTIONS TO GENERAL GEOLOGY, 1941

\section{NEPHELINE GABBRO AND QUARTZ GABBRO}

Dikes of rock related to gabbro were found in many places in the area cutting all the other rocks of the stock. Some of these dikes are as much as 300 feet across and over a mile long. They are especially abundant in the drainage basin of Deldorado Creek but were found in the upper drainage basin of North Beaver Creek, near the mouth of Huntsman Gulch, in the drainage basin of Sammons Gulch, in the banks of Cebolla Creek northeast of the Hot Spring, and near the mouth of Powderhorn Creek.

Two types of rock are represented in the dike-one a nepheline gabbro, the other a gabbro carrying a little interstitial intergrown quartz and orthoclase. The two rocks are in similar and nearly parallel dikes. The middle dike north of Deldorado Creek is composite and contains both rocks. This composite dike is mostly nepheline gabbro, but some quartz gabbro was found near its center. In one place the two rocks were seen in sharp contact and the nepheline gabbro appeared to have a chilled border, although the evidence of relative age was not clear.

The bodies on both sides of Huntsman Gulch near its mouth appear to be parts of a single dike, but the northern one is quartz gabbro, and the southern one is nepheline gabbro.

The two rocks are easily distinguished by one who is familiar with them, as each maintains its textural features with surprising persistence. The nepheline gabbro is characterized by large, conspicuous tabular feldspar crystals, which are usually several millimeters across; the quartz gabbro has less conspicuous and smaller feldspar.

No gradational rocks were found, and the contacts appear to be sharp. The two gabbros must represent separate intrusions, but one probably followed the other closely, as they occupy parallel dikes and, in part, practically form a single dike. Their relative age is uncertain, but both clearly intrude all the other rocks of the Iron Hill stock.

\section{NEPHELINE GABBRO}

The typical nepheline gabbro is a rather dark, coarsegrained rock that has conspicuous tabular plagioclase crystals in random to subparallel arrangement. It looks like a coarse diabase. These feldspar tablets are commonly 4 to 5 millimeters across and about a third as thick. In some of the coarser rocks they are over 10 millimeters across. Abundant pyroxene can be seen between the feldspar tablets, and olivine can commonly be seen in the pyroxene grains. Border rocks are fine-grained to aphanitic and contain a few feldspar phenocrysts.

The microscope shows that the texture of the rock is distinctly ophitic or diabasic. The pyroxene fills in between the plagioclase latlıs, and in places small grains of pyroxene are inclosed in the plagioclase. The plagioclase is labradorite. Locally it is zoned, and one specimen showed recurrent zoning with a core of labradorite $\left(\mathrm{Ab}_{40} \mathrm{An}_{60}\right)$ followed by a narrow zone of bytownite $\left(A b_{25} A n_{75}\right)$, then a narrow zone of labradorite, another zone of bytownite, and an outer zone of labradorite. The feldspar is fairly fresh, though a little sericite is common.

The augite occurs partly in glomeroporphyritic aggregates or subhedral crystals. It is commonly zoned. In some of these the main part and core is pale pinkish in thin section, but irregular borders are much darker pink. In others the cores are pale pinkish brown and the borders are light green. The pyroxene is sc mewhat altered to amphibole. In a few specimens it has been replaced by a uniformly oriented dark brown, strongly pleochroic hastingsite. A common alteration is to a dark-blue, almost opaque amphibole, probably related to riebeckite, which occurs in aggregates of fine fibers or as very small needles penetrating the feldspar. Rarely a strongly pleochroic green hornblende is present. It shows pleochroic halos about included grains of apatite.

Olivine in rounded, corroded grains is present in small amounts. It is mostly included in the pyroxene. A border of fine-grained magnetite commonly s?parates the olivine from the pyroxene. The olivine is more or less altered to serpentine, iron oxide, and iddingsite.

Nepheline was originally present to the extent of about 5 percent. It was interstitial to the other constituents and is almost completely altered to analcime, calcite, or a white, submicroscopic zeolite. Analcime is also present in small cracks in the feldspar. The minor accessories are magnetite, biotite, $\varepsilon$ nd apatite. The biotite is chiefly in reaction rims about the magnetite.

\section{QUARTZ GABBRO}

The quartz gabbro was found in several small, unmapped masses in the Iron Hill area in addition to those that are mapped. Near the south boundary of the stock south of Sammons Gulch there is a small body, and between Deldorado and Beaver Creoks west of the mapped dike several small dikes and irregular bodies were found cutting the syenite. Most of these are only a few feet across, and some are less then a foot across. Small outcrops were found in a few other places. Bodies of this gabbro cut the pre-C $\mathrm{mbrian}$ rocks several miles from Iron Hill. The largest of these is on the ridge northwest of the mouth of Powderhorn Gulch.

The quartz gabbros are somewhat finer-textured than the nepheline gabbros, and their feldspars are not so prominently tabular. Their texture tends to be typically gabbroic. The grain size is commonly from 1 to 3 millimeters. They lack nepheline and olivine and have approximately 10 percent of interstitial intergrown quartz and orthoclase. Their pyroxene is 
brownish and is not zoned. It has a small variable axial angle and is pigeonite.

Usually the quartz gabbros show considerable alteration, which was probably hydrothermal. The plagioclase has commonly been altered to sericite and a little epidote. Some of the pyroxene has been altered to a brown hornblende rimmed by a medium-blue hornblende. A deep-blue, almost isotropic amphibole, occurring in fiberlike growths, also appears to have been derived from pyroxene. It shows a deep-blue pleochroism along the length of the fibers and a medium-blue to brownish color transverse to the length and has a very small extinction angle. It is probably riebeckite. The amphibole is in many places associated with irregular blebs of magnetite. The deep-blue amphibole is later than the brown hornblende.

\section{CHEMICAL ANALYSES, NORMS, AND MODES}

Analyses, norms, and modes of the typical gabbros are shown in the following table. Both rocks are rather uniform in character.

TABLE 12.-Analyses, norms, and modes of nepheline gabbro and quartz gabbro

Analyses

\begin{tabular}{|c|c|c|}
\hline - & 1 & 2 \\
\hline 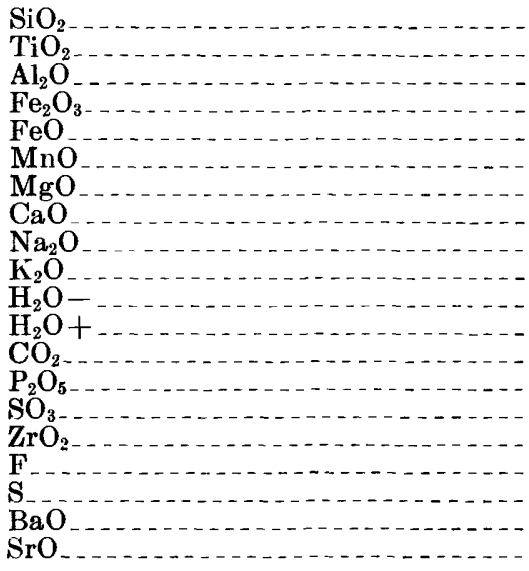 & $\begin{array}{r}\text { 47. } 94 \\
1.12 \\
22.56 \\
2.02 \\
4.77 \\
.11 \\
2.06 \\
12.08 \\
4.02 \\
.84 \\
.24 \\
1.30 \\
.16 \\
.25 \\
.02 \\
.14 \\
.03 \\
.39 \\
.31\end{array}$ & 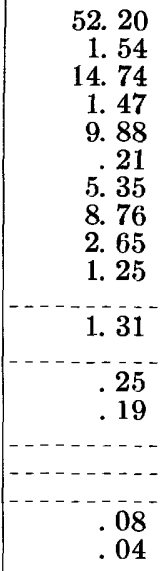 \\
\hline Specific gravity of hand specimen... & $\begin{array}{r}\text { 100. } 36 \\
\text { 2. } 954\end{array}$ & $\begin{array}{c}99.92 \\
2.981\end{array}$ \\
\hline
\end{tabular}

Norms

\begin{tabular}{|c|c|c|}
\hline & 1 & 2 \\
\hline 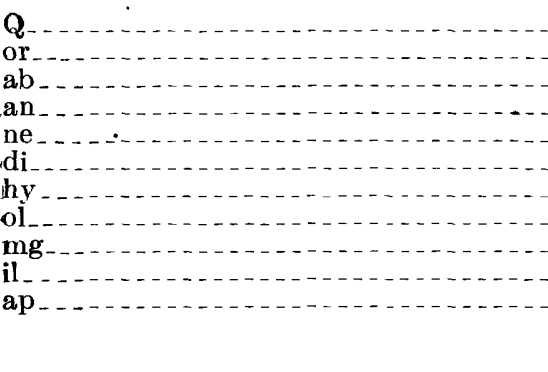 & $\begin{array}{r}5.00 \\
22.52 \\
40.87 \\
6.25 \\
15.43 \\
2.27 \\
3.02 \\
2.13 \\
\text { II. } 5^{\prime \prime} .67 \\
\text { (4) } \dot{5}^{\prime \prime} 4 .\end{array}$ & $\begin{array}{r}3.84 \\
7.23 \\
20.96 \\
25.30 \\
13.64 \\
21.52 \\
2.09 \\
2.89 \\
\text { "III. }{ }^{\prime \prime}{ }^{\prime} 67 \\
\text { (4).4. }\end{array}$ \\
\hline
\end{tabular}

TABLE 12.-Analyses, norms, and modes of nepheline gabbro and quartz gabbro-Continued

\begin{tabular}{|c|c|c|}
\hline \multicolumn{3}{|l|}{ Modes } \\
\hline & 1 & 2 \\
\hline $\begin{array}{l}\text { Quartz } \ldots . . . . . \\
\text { Orthoclase }\end{array}$ & & $\begin{array}{r}4 \\
10\end{array}$ \\
\hline $\begin{array}{l}\text { Plagioclase } \\
\text { Nepheline }\end{array}$ & 169 & 241 \\
\hline $\begin{array}{l}\text { Nepheline } \\
\text { Pyroxene }\end{array}$ & $\begin{array}{r}6 \\
19\end{array}$ & 39 \\
\hline Olivine & 1 & \\
\hline${\text { Magnetite and } \text { ilmenite }_{\ldots} \ldots \ldots}$ & 2 & 4 \\
\hline Apatite & 1 & Tr. \\
\hline Biotite & & 2 \\
\hline 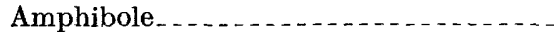 & 2 & \\
\hline
\end{tabular}

$$
{ }^{1} \mathrm{Ab}_{38} \mathrm{An}_{62} .
$$

1. Nepheline gabbro (U-1172). From the middle long dike between gulches $\mathrm{G}$ and $\mathrm{H}$ of Deldorado Creek. The mode was determined on a thin section with an area of 230 square m.illimeters. Some of the plagioclase crystals have areas of c-oss section as large as 6 square millimeters. The Rosiwal determination should therefore be correct within a few percent. The nepheline is partly altered to zeolites, but the rock is otherwise fresh. George Steiger, analyst.

2. Quartz gabbro (I-H.301). East bank of Cebolla Creek 25 yards south of road to Cebolla Hot Springs. The mode was determined on a large thin section with an area of 500 square millimeters and should be accurate within about 1 percent. The rock has a grain size of about 1 millimeter and is made up of stout tablets of labradorite with poorly formed grains of pyroxene, interstitial micrographic intergrowths of quartz and orthoclase, and a little biotite and magnetite. The rocl is somewhat altered and has sericite or a clay mineral related to montmorillonite in the feldspar, some chlorite from the biotite, and a little green and bluish amphibole from the pyroxene. F. A. Gonyer, analyst.

\section{OTHER DIKE ROCKS}

In the area surrounding the Iron Hill stock, the pre-Cambrian rocks are cut by several dikes of syenite different from those of the Iron Hill stock, an associated shonkinite, and a single dike of olivine gabbro. ${ }^{22}$ Their alkalic affinities suggest that they may be related genetically to the Iron Hill rocks, but they are high in potash, whereas the Iron Hill rocks are high in soda. If they are related to the Iron Hill stock, tr ay determine the age of that stock as late pre-Cambrian, because the syenite and shonkinite are cut by. aplite and pegmatite dikes, and such dikes are confined to the pre-Cambrian of this region. Their mineral and chemical compositions, characterized by abundent hypersthene and much $\mathrm{K}_{2} \mathrm{O}$, seem to distinguish them sharply from the Iron Hill rocks.

\section{AUGITE SYENITE AND SHONKINITE}

Augite syenite was found in several small bodies in the northeastern part of the Uncompahgre quadrangle. The largest body crosses Wildcat Gulch $1 \frac{1}{2}$ miles above its mouch. It is about 1 mile long and 0.3 mile wide in

${ }^{22}$ Hunter, J. F., Pre-Cambrian rocks of Gunnison River, Colorado: U. S. Ceol. Survey Bull. 777, pp. 63-75, 1925. 
its southern part and wedges out to the north. Along its western border is a small body of a peculiar olivinerich shonkinite differentiate. A somewhat smaller body with a similar olivine-rich associate near its border lies west of Goose Creek, 1/1/4 miles south of Dubois. Near this are several smaller bodies. Smaller bodies were found 0.6 mile above the mouth of Wolf Creek, near Spencer, above the Lot mine, and on the west side of Willow Creek, $2 \frac{1}{2}$ miles south of Midway. Where the syenite intrudes the schists it cuts across their schistosity. It intrudes the granites of the Powderhorn region but is cut by pegmatite and aplite.

The augite syenite is a rather uniform rock. The typical rock is dark gray to black and contains biotite standing out as large poikilitic crystals. It is seriate to seriate prophyritic, and the average crystal is about 0.8 millimeter across. Some of the large augite grains reach 2 millimeters, and some of the poikilitic biotite plates are 8 or even 20 millimeters across. Microcline with some perthitically intergrown albite is the chief mineral. Crystals of albite are present in small amounts. Augite makes from 20 to 25 percent of the rock and has been partly altered to actinolite. Hypersthene is present in a few of the rocks, and biotite is less abundant than augite. Magnetite, apatite, zircon, quartz, sphene, rutile, and garnet are accessory minerals. In some of the border phases, especially in the lower Wolf Creek body, quartz is more abundant than in the normal rock. An analysis of the augite syenite from the middle of the Wildcat Gulch body is given in column 1 of table 13 . The rock is high in potash, but the related shonkinite has an even higher ratio of $\mathrm{K}_{2} \mathrm{O}$ to $\mathrm{Na}_{2} \mathrm{O}$. The syenites of the nearby Iron Hill area are relatively high in soda. The syenite of the Willow Creek dike appears to have more soda. It is distinctly prophyritic and may have contained nepheline. The augite and biotite are almost completely decomposed, and the rocks contain a secondary amphibole that resembles glaucophane.

The syenite body of Wolf Creek is coarser in texture, contains nore hornblende, and shows much differentiation. In the central portion crystals of microclinenicroperthite as much as 6 millimeters across include poikilitically albite, hornblende, quartz, and accessory minerals. The hornblende is secondary. Sphene is unusually abundant, and some of the crystals are 1 millimeter across. The border of the mass is a finegrained rock in which the mafic minerals exceed the feldspar. The perthite includes the other minerals. Hornblende is the chief dark mineral and augite and biotite are also present. The border and central types grade into each other. This border rock is similar to the most abundant rock of the Wildcat Gulch and Goose Creek areas, and the coarse central part is like the quartzose rock along the border of the Wildcat Gulch mass.
The body near the Lot mine is coarse-textured and richer in biotite than the other syenites.

The shonkinite was intruded along the borders of the augite syenite of Wildcat Gulch and Goose Creek. The body in Wildcat Gulch is about 50 feet wide and 200 feet long; that of Goose Creek is msller. It weathers in rounded forms and is characterized by a rough uneven surface and gives characteristic outcrops. The shonkinite is a tough, dark, medium- to coarse-grained rock, containing large glistening brown micas. The rock has a seriate porphyritic fabric, and the grains range from 0.5 to 5 millimeters in diameter. Orthoclase with a small axial angle about ecuals the augite in amount. Olivine is less abundant, biotite still less, and magnetite and apatite are accessory.

An analysis of the shonkinite from Wildeat Gulch is shown in column 2 , table 13 .

\section{OLIVINE GABBRO}

A dike of olivine gabbro cuts diorite about 12 miles north of Iron Hill, just east of Willow Creek and above the mouth of Sugar Creek. It is not over 200 feet across and about three-quarters of a mile long. Its outcrop is distinctive, owing to its peculiar rounded form, its rusty brown color, and its rough pitted surface. Megascopically the rock resembles the shonkinite described above. On the fresh surface it is a black medium-grained rock in which lustrous flakes of biotite and plagioclase, poikilitically including the other minerals, are conspicuous. It is exceedincly heavy and hard to break or trim. The minerals, named in approximate order of abundance, are olivine ₹augite $\lesssim$ labradorite $\left(\mathrm{Ab}_{45} \mathrm{An}_{55}\right)>$ biotite $\gtrless$ hypersthene $>$ magnetite. Secondary magnetite, serpentine, serisite, and a little chlorite are common.

TABLE 13.-Analyses and norms of augite syenite and shonkinite

\begin{tabular}{|c|c|c|c|c|c|}
\hline \multicolumn{3}{|c|}{ Analyses } & \multicolumn{3}{|c|}{ Norms } \\
\hline & 1 & 2 & & 1 & 2 \\
\hline 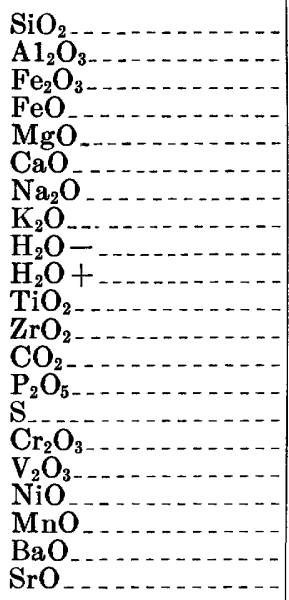 & $\begin{array}{r}54.99 \\
12.98 \\
3.13 \\
3.92 \\
5.50 \\
5.67 \\
2.83 \\
7.08 \\
.41 \\
.58 \\
.99 \\
.04 \\
\text { None } \\
1.00 \\
.05 \\
.01 \\
\text { None } \\
.04 \\
.13 \\
.47 \\
.17\end{array}$ & $\begin{array}{r}50.86 \\
11.14 \\
2.93 \\
5.21 \\
11.26 \\
6.97 \\
1.73 \\
5.85 \\
.64 \\
.95 \\
.84 \\
.02 \\
\text { None } \\
.79 \\
.02 \\
.11 \\
\text { None } \\
.04 \\
.13 \\
.31 \\
.22\end{array}$ & 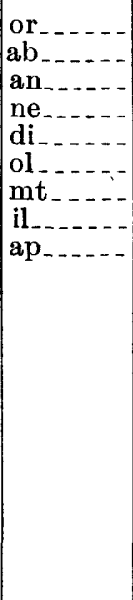 & $\begin{array}{r}42.26 \\
20.96 \\
1.39 \\
1.70 \\
17.63 \\
5.98 \\
4.41 \\
1.98 \\
2.17 \\
.\end{array}$ & $\begin{array}{r}35.03 \\
9.43 \\
5.00 \\
2.84 \\
20.29 \\
17.47 \\
4.41 \\
1.52 \\
1.86\end{array}$ \\
\hline Specific gravity & $\begin{array}{c}99.99 \\
2.833\end{array}$ & $\begin{array}{r}100.02 \\
2.94\end{array}$ & & & \\
\hline
\end{tabular}




\section{CARBONATE VEINS}

\section{CHARACTER}

Veinlike bodies of carbonates like that of the main mass of Iron Hill are numerous in the intrusive rocks of the Iron Hill stock and to a less extent in the surrounding pre-Cambrian rocks. In the drainage basins of Beaver and Deldorado Creeks these veins are especially abundant. Good exposures in the bed of a small gulch between the forks of Deldorado Creek showed a vein every 10 to 50 feet. The major veins are approximately parallel as indicated on the map, are a few feet across, and can be followed for nearly a mile. Many are smaller and form a network cutting the igneous rocks in all directions. No attempt was made to map the veins accurately, and only a very small proportion of the larger and more conspicuous ones are shown on the map, which is largely diagrammatic. In some places it is clear that the veins are later than the pyroxenite and other intrusives; but in others it was not possible to distinguish between vein carbonate and inclusions of marble.

The material of the veins is much like that of the older marble at Iron Hill. In part it is made up dominantly of dolomite with some apatite. Much limonite and ocherous opal and chalcedony are present in some of the veins. In places it is like the calcite-mica-aegirite-hornblende rock of the contact-metamorphic marble. The carbonate of some of the veins in Deldorado Creek and elsewhere contains a little pyrite, chalcopyrite, sphalerite, and galena, and these veins have been prospected for silver. Many of the veins are banded parallel to the walls. Commonly the center is nearly pure carbonate and the borders contain mica and the associated silicates. Some of the veins contain more or less quartz and albite or microcline, and locally they are made up chiefly of fine-grained quartz and feldspar. One vein just north of the south fork of Deldorado Creek and about 100 yards above its junction with the main fork is made up chiefly of ankerite $(\omega=1.725)$ with some sulfides, aegirite, orthoclase, anatase, and apatite. An 8-inch vein in the pyroxenite on the northeast slope of gully A carries stout prisms of aegirite 1 inch long arranged normal to the wall and embedded in calcite.

A different type was found as a 1-foot vein on the northeast slope of gully A about a quarter of a mile from the road up Cebolla Creek. Its borders are made up chiefly of coarse white calcite, with a very few millimeter grains of black magnesic hastingsite. The central 4 inches, which is rather sharply separated from the border, is nearly half hastingsite. Apatite is present. Small seams of hastingsite were found in other places. The hastingsite is everywhere in much larger crystals than the soda tremolite, and in one place along the road up Cebolla Creek south of Beaver Creek a 1-inch seam of hastingsite with grains 5 milli- meters in diameter cuts a rock with much very finely crystalline soda tremolite.

Veins of coarse calcite with a few centimeter-sized crystals of green diopside were found south of gully $\mathbf{A}$ and 350 yards east of the road up Cebolla Creek. Similar veins were found above the road up North Beaver Creek, just east of the gulch heading east, of Iron Hill, and elsewhere.

In veins of another kind the calcite contains abur dant grains of pyroxene and other minerals from the pyroxenite. These pyroxene grains have been more or less replaced and bordered by aegirite. Such a vein, 18 inches wide, is exposed in a prospect south of Deldorado Creek and northeast of the saddle east of Iron Hill.

Locally, fluorite is present in the veins, and a vein a few hundred feet south of the cancrinite syenite and east of the south fork of Deldorado Creek contains considerable very dark purple fluorite (gunnisonite). This fluorite is later than the carbonate and has replaced it.

\section{ORIGIN}

The carbonate veins cut the pyroxenite. Their form and relation to the pyroxenite seem to exclude the possibility that they are inclusions of older limestone, although some bodies might be interpreted either as thin slabs of included limestone or as veins of carbonate.

They could hardly have been squeezed into place by plastic flow of marble, for if so the pyroxenite should show evidence of the required pressure; yet its walls are sharp, and it shows no metamorphism, though it is a weak rock and very susceptible to metamorphism.

They are probably hydrothermal deposits. The presence of the galena and other sulfides, of the fluorite, quartz, orthoclase, and albite, and of the zones of silicates next to the borders all indicate a hydrothermal origin. There has been surprisingly littie alteration of the pyroxenite wall rock next to some of the veins, but others have extensively replaced the pyroxenite.

\section{HYDROTHERMAL PROCESSES}

Hydrothermal processes were active in and near the Iron Hill stock and were almost continuous from the deposition of the great mass of marble of Iron Hill to the cooling of the last intrusive of the stock. On the whole, these hydrothermal changes were somewhat greater than those that are usually associated with intrusives of this size. They ranged from the simple deposition of veins, in fractures or other open spaces, to large-scale replacement and recrystallization, under moderate and high temperatures or contact-metamorphic conditions. Although the greater part of the changes were brought about in or very near the stock, some deposition and replacement occurred several miles from the stock.

The earliest hydrothermal deposits are the great mass of marble of Iron Hill, the inclusions of marl ! 9 in 
the stock near Iron Hill, and probably the smaller irregular bodies in the older granite far from the Iron Hill stock. Next, the intrusion of the uncompahgrite was accompanied by some metamorphism of the marble and by extensive and successive replacements of the uncompahgrite itself. The pyroxenite brought about extensive contact metamorphism in adjacent parts of the marble. The intrusion of the ijolite was followed by extensive autometamorphism, during which the nepheline was converted to zeolites and less commonly to other minerals. Some replacement accompanied each of the later intrusions, and it affected mostly the newly crystallized rock. Numerous veins of dolomite accompanied by other minerals were formed late in the development of the stock. Deposition of aegirite and a sodic amphibole took place again and again. Replacement of the pyroxenes by magnesic hastingsite was less common.

\section{THE HYDROTHERMAL PRODUCTS}

The products that were formed by hydrothermal processes in the various rock formations have been described in the sections on the formations. In this section it is proposed to discuss the more general features of these products; to compare the products formed at one time in the history of the stock with those formed at another time, to compare the products formed in open veins with those formed by the replacement, and to compare those that replaced one rock or mineral with those that replaced some other rock or mineral.

Carbonate type--Deposits in which carbonates are the chief minerals make up a greater part of the hydrothermal deposits than any other type, even exclusive of the great mass of marble of Iron Hill. Most of the carbonate is dolomite, but calcite is rather abundant and ankerite is locally present.

Two main periods of deposition of carbonate rocks are apparent, and no doubt there were other times when more or less carbonate rock was formed. The great mass of marble of Iron Hill is the oldest rock recognized in the Iron Hill stock, and the abundant carbonate veins were formed after the intrusion of the nepheline syenite.

The marble of Iron Hill was nowhere seen in contact with older rocks, but the small bodies of marble in the granite that surrounds Iron Hill have sharp contacts, and next to the contact there has been only a slight replacement of the granite by aegirite and sodic amphibole. The veins cut the older intrusives of the stock with sharp contacts, and there has been little alteration of the adjoining rock, although a narrow border zone of the veins contains aegirite and sodic amphibole.

Carbonate is widely distributed in the alteration products of the rocks of the stock, but it occurs in small or moderate amounts.
The marble of Iron Hill and the carbonate veins are very much alike: both are relatively pure and coarsely crystalline, both are made up chiefly of dolomite, both have apatite as one of the chief impurities, and both have narrow borders containing aegirite and sodic amphibole where they are in contact with the older rock. The earlier marble of Iron Hill has, in addition to carbonate and apatite, a little pyrite- possibly introduced by the pyroxenite- - and no other imfortant original minerals. The carbonate of the veins contains a little pyrite, galena, sphalerite, and locally fluorite, quartz, and feldspar, all of which may have been introduced into the original carbonate veins.

A surprising similarity exists between the great mass of marble of Iron Hill, the small veins and less regular bodies that are in the granite, and the later carbonate veins that cut the Iron Hill stock. The deposits appear to be essentially the same whether they cut granite, pyroxenite, ijolite or any other rock.

Apatite-magnetite-carbonate veins and iron oxide veins. - A few veins made up of varying amounts of apatite, magnetite (now martite), and carbonate with some quartz, albite, phlogopite, and orthoclase cut the marble of Iron Hill. Replacement veins or less regular bodies of hematite with siderite and some secondary manganese minerals also cut the marble of Iron Hill. They are both believed to have been deposited by solutions emanating from the pyroxenite.

Aegirite-amphibole.-A type of hydrothermal deposit characteristic of the Iron Hill area contains aegir te and an amphibole related to soda tremolite and glaucophane as the peculiar minerals; it also commonly contains more or less phlogopite and much less commonly orthoclase, albite, and quartz. Deposits of this type were formed throughout the history of the stock, under a variety of conditions, and in nearly all the rocks of the area. The following paragraph give some of the conditions under which they are found.

1. Along the borders of the old carbonate deposits and the pre-Cambrian granitic rocks in whicl they were formed.

2. Along seams and fracture planes in the preCambrian granites and schists. In places, ever at a distance of several miles from the Iron Hill stork, all the angular fragments of the granites are coated with a thin veneer of aegirite and sodic amphibole, and near the stock this is especially true. In some places the minerals of the granite, especially the mafic minerals, have been more or less replaced. The older rocks have been replaced locally by these minerals along veinlike seams and along networks of fractures.

3. Aegirite, sodic amphibole, and phlogopite sre the chief minerals formed in the marble of Iron Hill as a hydrothermal contact-metamorphic aureole about the pyroxenite.

4. Along the borders of the later carbonate veins these minerals have been formed to a slight exten $t$. 
5. The intrusive rocks of the stock have locally been veined and replaced by these minerals, and the soda syenite in many places has been sliced into thin sheets, along which sodic amphibole and some associated aegirite have been deposited. Locally they have replaced the pyroxene of the syenite and to a less extent the other minerals.

Hastingsite and diopside.-In many places, but nowhere on a large scale and mostly along narrow seams, the pyroxene of the uncompahgrite, the pyroxenite, and the ijolite are altered to a black amphibole, magnesic-hastingsite, with some associated granular light-green diopside. In most places this amphibole occurs in large crystals, commonly larger than those of the parent diopside-hedenbergite.

A few small veins of calcite have a central zone rich in coarsely crystalline magnesic hastingsite. A few others have scattered grains of pale-green diopside.

Melanite.-A black titaniferous garnet, melanite, is a common mineral in the stock and has been found in all the rocks of the stock except the nepheline gabbro and quartz gabbro. It is most abundant in the ijolite and is found in very few places in the soda and nepheline syenites. It is in part a late pyrogenic mineral, but it continued to form after the residual mother liquid left the interstices of the rock and gathered into veins. It replaced melilite, nepheline, calcite, and other minerals. Some replacement veins made up mostly of melanite are 1 foot across, but most are less than 1 inch. In many places the melanite is associated with phlogopite or calcite. In a single vein cutting uncompahgrite it is associated with idocrase, monticellite, and coarsely crystalline cancrinite.

Alterations of melilite.-The alteration of the uncompahgrite is described in the section describing that rock, and only an outline will be given here. To a small extent melanite replaced the melilite in uncompahorite. Toward the end of the formation of garnet that mineral become poorer in iron, and idocrase began to form with the garnet. Diopside with idocrase followed closely. This alteration to diopside and idocrase took place along fractures, and some seams of these minerals are present in nearly every block of the rock; in considerable parts of the uncompahgrite the melilite has been completely replaced.

The remaining melilite was later attacked by solutions that successively formed four or more hydrous minerals. In all these changes there was little change in composition other than the addition of water.

Zeolites, cancrinite, and analcime.--In many places the nepheline was altered to natrolite (hydronepheline) and rarely to other zeolites. Less commonly it was altered to cancrinite and locally to analcime.

Other types.-Titania in the form of anatase has been introduced into the hydrothermal and contact-metamorphic aureole in the marble about the pyroxenite. In places the spheres in some of the pyroxenites that are especially rich in that mineral may be hydrothermal rather than magmatic. The olivine in the olivine pyroxenite and in the nepheline gabbro has been more or less altered to serpentine. In some of the syenites secondary albite has replaced the original microcline, and an uncertain amount of the albite rims around the microperthite may have been formed in this way. The pyroxenes of the nepheline gabbro and quartz gabbro have been replaced to some extent by alkalic amphiboles. Locally the feldspar and the nephe'ine have been sericitized. Brugnatellite was found locally.

\section{CONCLUSIONS}

From the preceding descriptions it is obvious that the minerals formed were appreciably the same from the earliest deposits, which preceded the intrusion of the uncompahgrite, to the latest, which are as late as the intrusion of the syenites and probably later. Tay were the same whether the deposition was associated with the intrusion of uncompahgrite, pyroxenite, ijolite, or syenites.

The deposits formed in open spaces are predominantly carbonate, but nearly all have a narrow border of the aegirite and sodic amphibole rock, and where the open space was very small the carbonate may be lacking. The minerals appear to be nearly independent of the wall rock, whether granite, pyroxenite, or other rock.

In the contact-metamorphic deposits in marble the minerals are aegirite, amphibole, and phlogopite. The same mineral assemblage with little phlogopite is found along the borders of the carbonate veins and replacing the granite, the syenites, and to a less extent other rocks.

Replacement of the hastingsite type has occurred in nearly all the rocks, and hastingsite was found in a single carbonate vein.

The melanite was found in most of the igneous rocks of the stock, and everywhere it formed partly as a Jate pyrogenetic mineral and continued to form after the residual solutions had begun to move along fractures.

The conditions that determined whether hasting:ite and diopside or aegirite and sodic amphibole were formed are not clearly known, and the age relations of the two were nowhere determined. They show so little difference in composition, except possibly for ferric iron content, that temperature would seem to have been the controlling factor.

\section{CHEMISTRY}

The material brought into the veins and replscement deposits was nearly all carbonates of calcium and magnesium with some iron. Calcium phosphate and possibly iron sulfide with calcium fluoride were next in amount. Except for the contact-metamorphic deposits most of the oxides going into the silicates of the deposits could have been and probably were mostly 
furnished by the replaced or adjoining rock. However, a little soda and in some places potash must have been added, some iron was oxidized, and very small amounts of lead, zinc, and sulfur were added.

The formation of the contact-metamorphic silicate rocks from the marble required the addition of ferric iron, soda, potash, silica, alumina, and titania and the removal of carbonate, mostly magnesium carbonate.

From a purely chemical consideration the solutions need not have been very different from those emanating from granites and granodiorites, yet the minerals deposited are very different. The chemical differences are a lack of sufficient alumina to combine with all the alkalies and an unusually large amount of magnesium and calcium carbonates in the deposits. Ferric oxide may have been very high, but not necessarily so. Low alumina is a characteristic of the magma itself, as, except in the last dike rocks, no alumina was available for lime feldspar and in some not enough to combine with all the soda. There was a further deficiency of alumina in the residual liquid of the magma, as shown by the common increase in the acmite molecules in the bordering parts of the pyroxene crystals and the abundance of aegirite and sodic amphibole in the hydrothermal products. High lime and magnesia are also characteristic of the rocks.

\section{COMPARISON WITH OTHER AREAS}

Near Libby, Mont., in the stock of alkalic rocks much like that of Iron Hill, aegirite is an abundant hydrothermal mineral, especially in the syenites, and the pyroxenite is traversed by many veins along which the pyroxene has been replaced by a fibrous amphibole that is identical with the amphibole at Iron Hill. The few veins at Libby are dominantly quartz, and there are no carbonate veins such as those at Iron Hill. ${ }^{23}$

The Fen district in Norway has many features that are similar to the Iron Hill area. I have examined a suite of specimens from the Fen district, and from that examination and from Brögger's descriptions ${ }^{24}$ I make the following comparisons. The carbonate rocks of the Fen district are believed by Brögger to be igneous rocks. In a border zone of a dike of "ringite pegmatite in fenite" the ringite near the contact is chiefly carbonate, with much aegirite in radial bunches and apatite. It is very similar to the border zone of the carbonate veins at Iron Hill. The "fenitized granite" of Brögger is identical with the granite about the Iron Hill stock where it has been impregnated with and replaced by aegirite and sodic amphibole. Brögger ${ }^{25}$ attributed the fenite to impregnation of the granite by solutions

${ }^{23}$ Pardee, J. T., and Larsen, E.S., Deposits of vermiculite and other minerals in the Rainy Creek district near Libby, Mont.: U. S. Geol. Survey Bull. 805, pp. 22-28, 1929. Larsen, E. S., and Pardee, J. T., The stock of alkaline rocks near Libby, Mont. Jour. Geology, vol.37, pp. 109-112,1929.

${ }^{24}$ Brögger, W. C., Das Fengebiet in Telemark, Norwegen: Vidensk. selsk. Oslo Forh., no. 9, pp. 167-179, 1921.

${ }^{26}$ Idem, p. 172. from the ijolite-melteigite magma. The specimens of fenite from Norway at my disposal are almost identical with the soda syenite of Iron Hill, where it has been somewhat sheeted and the original diopside-hedenbergite has been replaced by aegirite and soda amphibole and the same minerals have been deposited along the fracture planes. In the Iron Hill area the syenite has no close relation to the granite contacts or to ijolite. It has a sharp intrusive contact with the granite and is undoubtedly an intrusive syenite. It is probably much better exposed than is the fenite in the Fen district.

Kranck ${ }^{26}$ has described the introduction of albite, aegirite, and an amphibole into the granite and other rocks about the ijolite in the Turja area, Kola, P.ussia. In the turjaite "the melanite is the last-formed of the essential components of the rock and probably does not belong to its ordinary liquid-magmatic products. Its period of formation coincides partly with the pneumatolytic stage of the rock." ${ }^{27}$ Kranck found melanite in veins and garnet with light-colored borders. All these statements might have been made as truly about the Iron Hill area. Kranck also found the melilite of the turjaite altered in much the same way as the melilite of the uncompahgrite of Iron Hill.

Somewhat similar hydrothermal deposits have been described elsewhere. They show that the hydrothermal products of the Iron Hill area are rather typical of alkalic rocks of this kind.

\section{GENERAL CHARACTER OF THE STOCK} SUCCESSION OF EVENTS

The succession of events described on the preceding pages is summarized as follows:

All the rocks of the stock are younger then the surrounding pre-Cambrian rocks. The marble is the oldest rock of the area, and it is believed to have been deposited by hydrothermal solutions, probably in an open space. The uncompahgrite wa next injected and later hydrothermally altered to a considerable extent by solutions emanating from the magma itself. The pyroxenite intruded the marble, the uncompahgrite, and the pre-Cambrian rocks, and it was followed by the ijolite. The soda syenite wa next intruded, chiefly near the borders of the stock. There was some faulting around the borders of the stock during the injection and crystallization of the soda syenite. The nepheline syenite was then injected into all the older rocks but chiefly along the southeast border of the stock. Both the nepheline syenite and the soda syenite form irregular, discontinuous rings around the stock. The nepheline gabbro and quartz gabbro were finally introduced in separate injestions, but probably not separated by any great length of time.

\footnotetext{
26 Kranck, E. H., On turjaite and the ijolite stem of Turja, Kola: Fennia 51, no. 5 1928.

27 Idem, p. 22.
} 
Throughout the period of these intrusions hydrothernial solutions were active. Contact-metamorphic solutions from the pyroxenite replaced parts of the niarble; later solutions fron pyroxenite and other rocks formed nunierous carbonate veins and replaced the minerals of the rocks of the stock and of the surrounding pre-Canibrian rocks along fractures. The ninerals so forned were uniformly carbonates (dolomite with less calcite and ankerite), aegirite, soda anıphiboles, phlogopite, and apatite, with sniall amounts of nuagnetite, orthoclase, albite, quartz, fluorite, sulphides, and other minerals.

\section{RELATIVE SIZE OF FORMATIONS}

The areas occupied by the coniponents of the stock are tabulated below.

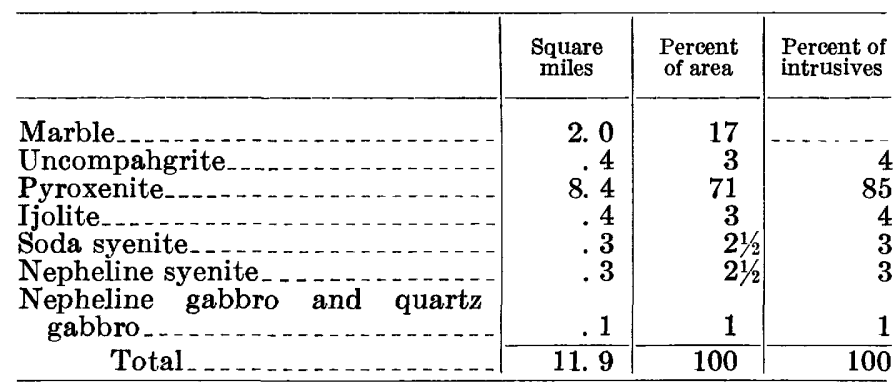

MINERAL CHARACTER OF THE STOCK

Table 14 (p. 36) gives the estimated average nineral coniposition of the components of the stock and of the stock as a whole. Only the primary ninerals are listed. The quartz gabbro, the nepheline gabbro, the syenite, and the nepheline syenite are fairly uniform in nineral coniposition; the uncompahgrite varies soniewhat, the ijolite varies greatly, and the pyroxenite still more.

If the section along the present surface represents a fair sample of the stock, the felsif minerals niake up only about 11 percent of the stock. Of these ninerals quartz is present only in very rare pegmatitic segregations in the pyroxenite, rarely in the soda syenite, and as an essential though ninor constituent in the quartz gabbro. Feldspar makes up only 6 percent of the stock, and albite is in somewhat greater anount than microcline. Lime feldspar is confined to the nepheline gabbro and quartz gabbro, which are satellitic to the main stock. Nepheline is about one-third as abundant as feldspar, and nielilite about half. Calcite is a primary nineral and is widely distributed, chiefly near marble bodies, but it is rarely present in more than minor amounts.

The pyroxenes make up over half the mass, and diopside-hedenbergite nuakes up 99 percent of the primary pyroxene. Pyroxene rich enough in acmite to be called aegirite is rare in the igneous rocks and is found only in the syenites, although it is the chief mineral formed by the hydrothermal proxesses.

Biotite is erratically distributed in the pyroxenites, and it forms nearly all of some small patches. It is also present in the ijolite, the unconıpahgrite, and the nepheline syenite. In all places it was a very late mineral to crystallize.

Olivine, in spite of the low silica content of noost of the rocks, is found in the nuain rocks of the stock only in the very rare dikelets of olivine pyroxenite, in which it may make up over half the rock. It is also an essential nineral in the nepheline gabbro.

The titaniferous garnet, melanite, is widely distributed as a very late pyrogenetic nineral or as a deuteric nineral. It is often associated with calcite. It is an abundant though erratically distributed mineral only in the ijolite.

Perofskite is an abundant accessory in the ijolite, unconıpahgrite, and pyroxenite, and in some "ores" in the pyroxenite it nlakes up over half the rock. Titar ite was found in nost of the formations, but it is erraticslly distributed; it is closely associated with alkalic feldspar, and less closely with nepheline and calcite. Locally it makes up half the rock. Magnetite is the chief ore; it is abundant in all the rocks, and forms with perofskite local bodies of iron ore. It is intergrown with a little ilmenite.

Apatite is an abundant accessory, and in some small bodies of the pyroxenite it niakes up two-thirds of the rock: Zireon is a rare accessory.

The characteristics of the mineral assemblage sem to be these:

1. Almost entire lack of quartz in the main rocks of the stock.

2. Almost entire lack of lime in the feldspar of the rocks of all but the last two satellitic intrusions.

3. Slight excess of albite over orthoclase + microcline.

4. Importance of nepheline and melilite among the felsic constituents.

5. Presence of primary calcite in small amounts.

6. Very small amounts of total felsic minerals.

7. Large amount of pyroxene.

8. Complete absence of hypersthene.

9. Complete absence of primary amphiboles.

10. Moderate abundance of biotite, which is mostly low in iron and was a late mineral to crystallize.

11. Extreme scarcity of olivine in these low silica rocks except in the satellitic nepheline gabbro.

12. Wide distribution of melanite as a late or deuteric mineral.

13. Abundance of perofskite in the first three intrusives.

14. Erratic distribution of the sphene and its association with feldspar, nepheline, and calcite.

15. Magnetite containing some ilmenite forming the chief ore mineral in most of the rock.

16. Fluorapatite an abundant constituent, and small diker of nearly pure apatite present.

17. Rarity of zircon.

\section{CHEMISTRY OF THE STOCK}

The approximate average chemical composition of the various intrusive bodies of the stock and the average composition for the stock are shown in table 14 . For the analyses of the varieties of the pyroxenite, ijolite, and uncompahgrite, see the descriptions of the formations. 
The chemical characteristics of the stock are as follows:

1. Extremely low silica in the local masses of ore in the pyroxenites and in the uncompahgrite and ijolite, and moderate silica in the other rocks and in the average rock.

2. Very low alumina in the pyroxenite and uncompahgrite, and moderate to high alumina in the younger rocks. The average is very low.

3. Somewhat greater amount of ferric than ferrous iron in nearly all the rocks. Total iron is high in the average rock and in the pyroxenite.
4. Magnesia rather high in the pyroxenite but not especially high in most of the other rocks.

5. Lime extremely high in the uncompahgrite, the py"oxenite, the ijolite, and the average rock and rather high in the repheline gabbro.

6. Soda in excess over potash in nearly all the rocks, very low in the pyroxenite and low in the uncompahgrite, but moderate to high in the other rocks.

7. Of the minor constituents, titania is very high in all the rocks and becomes an essential constituent, phosphate and manganese are rather high, primary $\mathrm{CO}_{2}$ is present, baria, strontia, and fluorine are rather high.

TABLE 14.-Average chemical composition and modes of mapped units of the Iron Hill siock, arranged in order of decreasing age

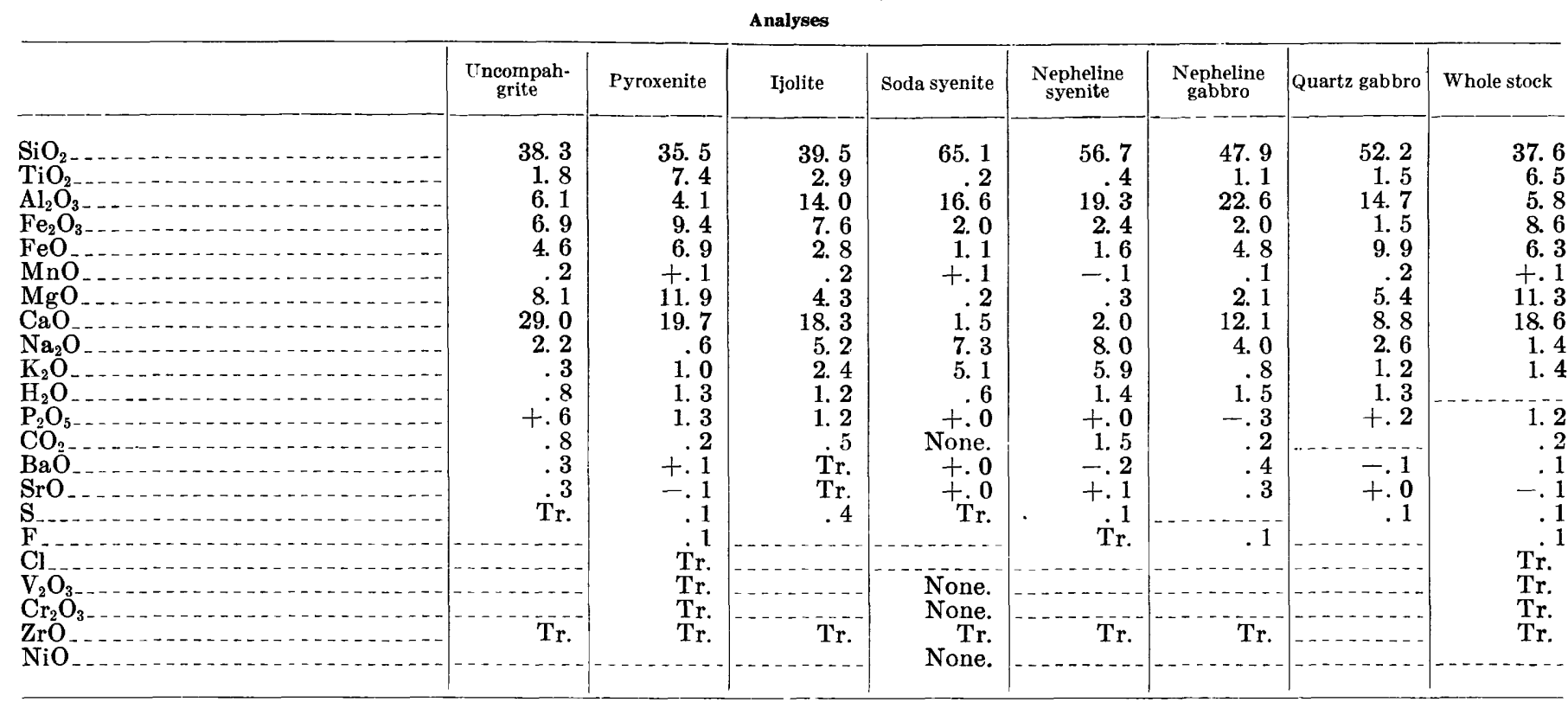

Modes

[Weight in percent]

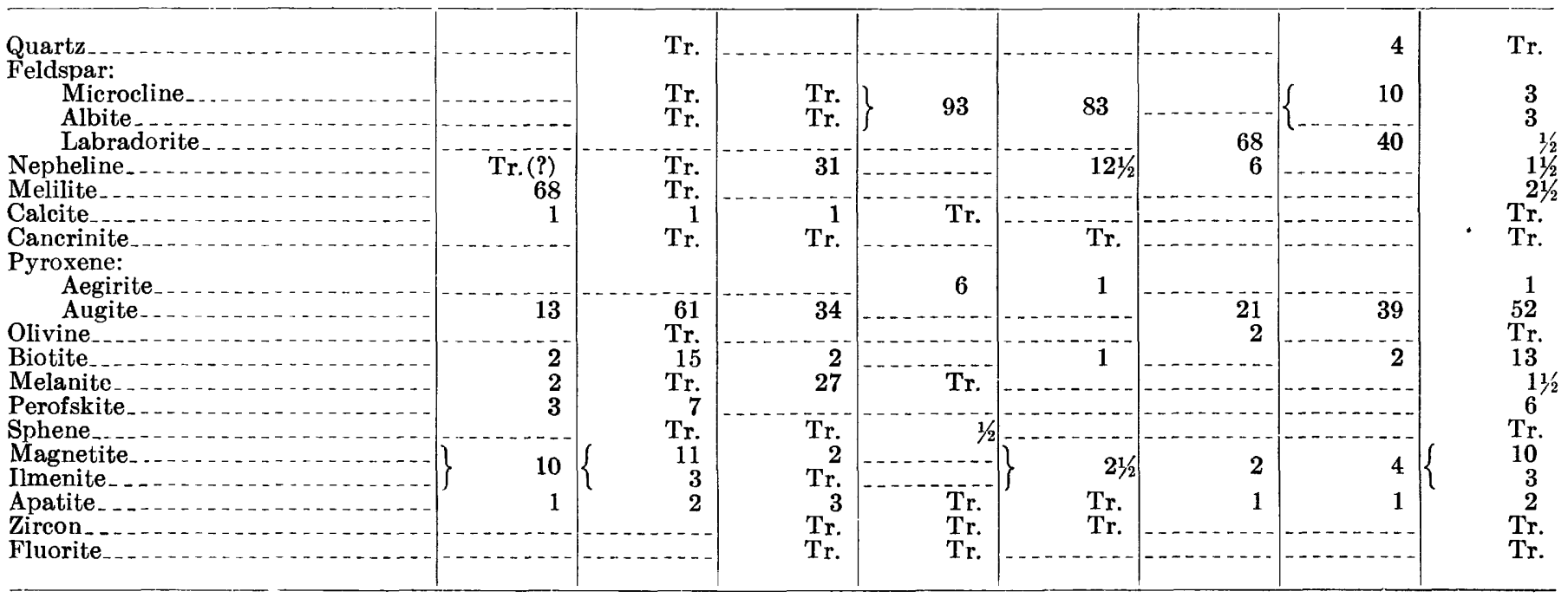

\section{PETROGENESIS}

\section{COMPARISON WITH SIMILAR MASSES}

Daly ${ }^{28}$ and Brögger ${ }^{29}$ have reviewed the literature describing alkalic bodies similar to that of Iron Hill, and only a tabulation of the essential features of some of the most closely related bodies is given in tables 15 and 16 for comparison.

${ }_{28}$ Daly, R. A., Igneous rocks and the depths of the earth, pp. 501-541, McGraw-Hill Book Co., 1933.

${ }^{20}$ Brögger, W. C., Das Fengebiet in Telernark: Vidensk. selsk. Oslo Forh., 1920, no. 9, pp. 20-50, 573-591. 
ALKALIC ROCKS OF IRON HILL, GUNNISON COUNTY, COLO.

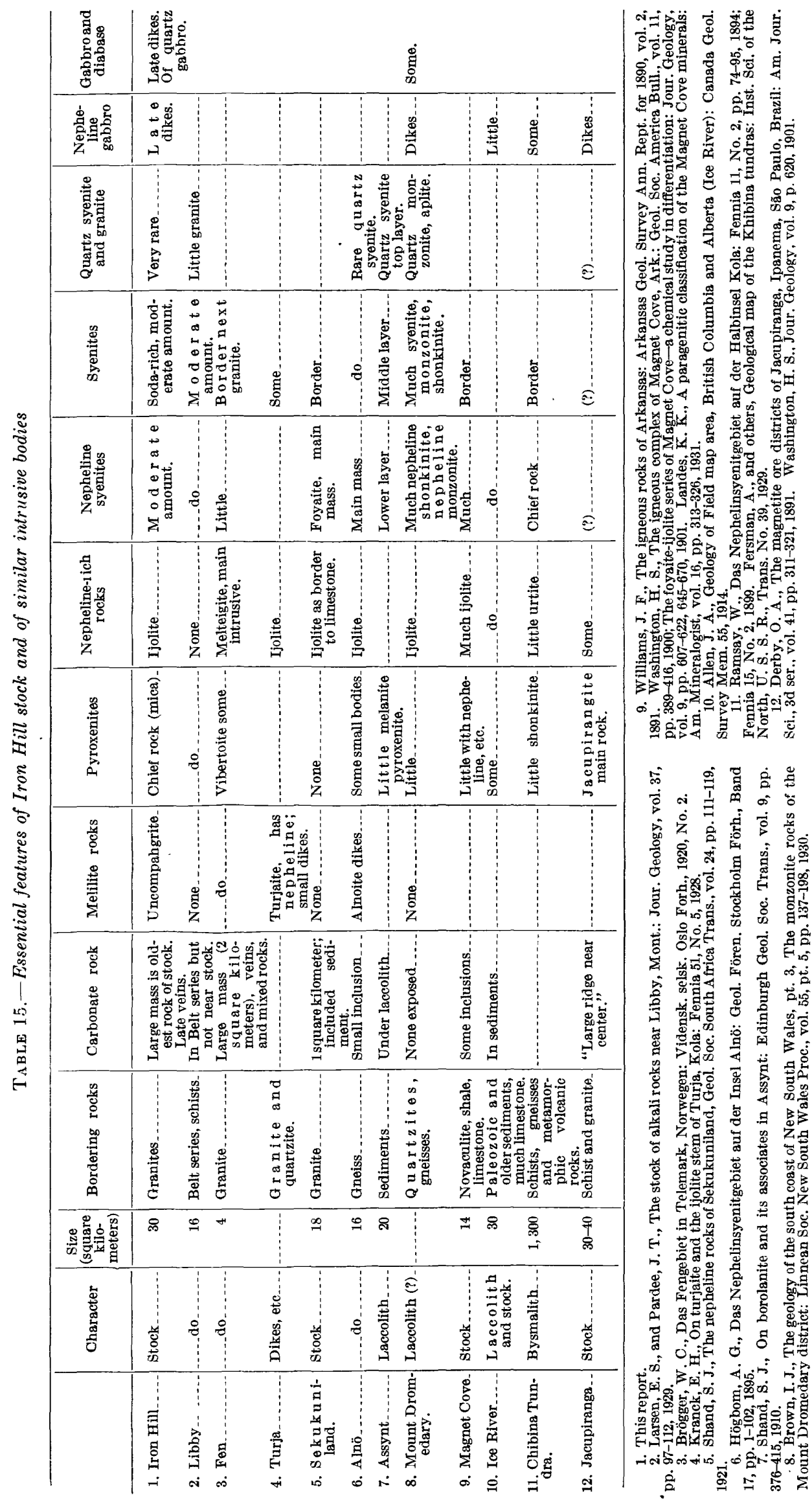




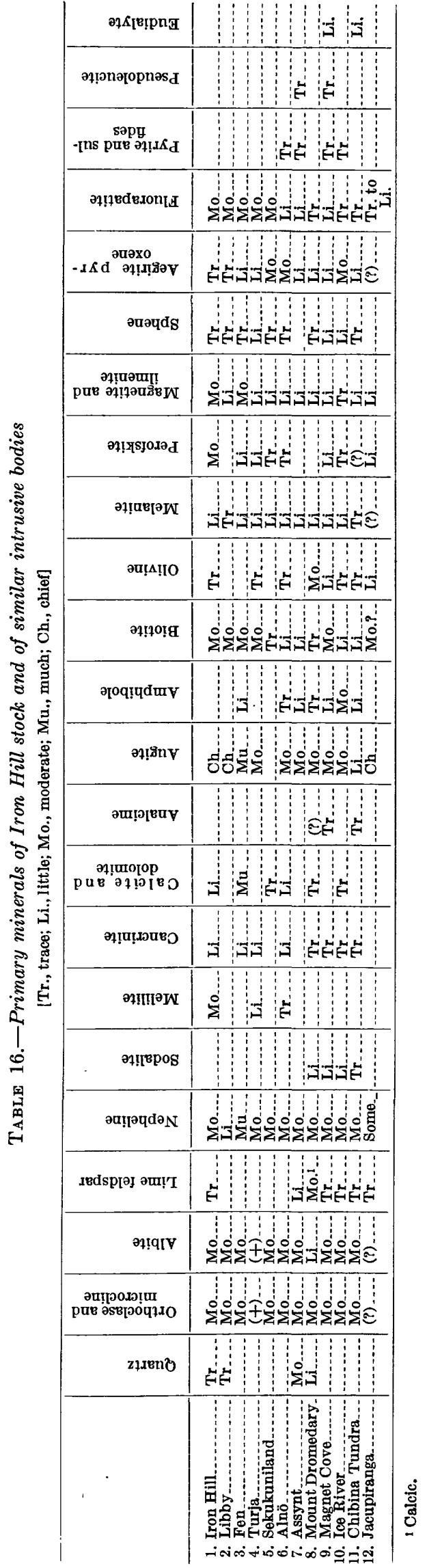

Of the twelve provinces tabulated those most closely resembling that of Iron Hill are Libby, Mont.; Fen, Norway; Turja, Kola; Sekukuniland, South Africa; Alnö, Sweden; Mount Dromedary, New South Wales; Magnet Cove, Ark.; Ice River, B. C.; and Jacupiranga, Brazil. Assynt, Scotland, and Chibina Tundra, Kola, are more nearly of the ordinary alkalic provinces and are less similar to Iron Hill. All are stocklike bodies or bysmaliths, except Assynt, Mount Dromedary, and part of the Ice River. Most of them are less than 30 square kilometers in surface area; Jacupirsnga is 30 to 40 square kilometers; Mount Dromedar" is 65 square kilometers and Chibina is 1,300 square kilometers.

Rocks.-Iron Hill, Fen, Sekukuniland, Alnö, Magnet Cove, and Jacupiranga-half the bodies listed-have unusual inclusions or bodies of limestone that, must have come from some distance. In most of these the source of the limestone is one of the difficult problems presented. In Assynt and Ice River the stock is in immediate contact with large bodies of limestone.

The melilite rock (uncompahgrite) has been found only in the Iron Hill stock. Melilite-nepheline rocks have been described from Turja and Alnö.

Pyroxenite is the chief rock of the Iron Hill, Libby, and Jacupiranga stocks and is present in smaller amounts in nearly all the others. The pyrosene of this rock is mostly augite containing little soda or aluminum. The pyroxenite is everywhere rich in apatite, and nearly all but that of Libby is rich in titanium, mostly in the form of perofskite. Biotite occurs in moderate amount in the pyroxenites, and parts of the pyroxenites are rich in it; some are nearly pure biotite. The pyroxenite is in every occurrence highly variable and patchy. Local bodies of "iron ore" have been found at Iron Hill, Alnö, Magnet Cove, Ice River, and Jacupiranga. In most of the bodies the pyroxenite in places has a little nepheline, or alkalic feldspar. It is mostly of the jacupirangite type.

A nepheline-rich rock, a member of the ijolite-melteigite series, is present in all the bodies but those at Assynt and Libby; in some of them it is the chief rockIt commonly carriers a titaniferous garnet near melanite. Nepheline syenites are present in all the bodies with the possible exception of those of Turja and Jacupiranga, and in many it is the chief rock. Syenites are present in all the bodies except those of Ice River and possibly Jacupiranga. In nearly all the stocks they tend to occur near the borders. Quartz-bearing rocks have not been reported from most of the bodies; they are present in traces at Iron Hill, Libby, and Alnö and in large amounts at the top of the laccolith of Assynt. Nepheline gabbros are present in dikes in some of the stocks, and quartz gabbro only at Iron Hill. 
Mineralogy.-The primary minerals are much alike for all the bodies. Quartz is absent or present only in traces in all except Assynt. Orthoclase (including microcline) and albite, mostly intergrown as perthite, are abundant minerals in all, except possibly Turja and Jacupiranga. Lime-bearing feldspar is reported from about half the stocks but only in traces. Nepheline is one of the chief minerals in all the bodies. Sodalite and analcime are found in some; melilite, in amounts as high as a few percent, is found in about half. Cancrinite or carbonate occur in small amounts as primary minerals in about half the stocks, and in four they are both present.

Augite is the chief mineral in the Iron Hill, Libby, and Jacupiranga stocks, and it is abundant in nearly all the others. It is low in alumina at Libby and Iron Hill but is aluminous at Magnet Cove and Jacupiranga. Biotite is a major accessory or in moderate amount in all the bodies except that at Assynt. It is present mostly in the pyroxenite. Olivine is found in traces in most of the bodies. Orthopyroxene is entirely absent. A titaniferous garnet, near melanite, and perofskite occur in small amounts in nearly all the bodies. Titaniferous magnetite is present in more than average amount in all. Sphene is present in nearly all, and in several of the stocks local bodies of rock carry 10 percent or more of this mineral. A pyroxene with much acmite molecule is present in all the bodies, but in most it is subordinate in amount to the augite. It is found chiefly in the rocks with feldspar and feldspathoids. Apatite is present in unusually large amounts in nearly all the bodies except that of Ice River. Sulfides, pseudoleucite, eudialyte, inicrolite, and wollastonite are present in some of the bodies.

Chemical character.-The chemical character of the different stocks, which can best be judged from the rocks and the minerals present, is remarkably consistent. The main constituents are mentioned below in order:

Silica is Jow in all. Titania is high, especially in the proxenites and ijolites. It is not unusually high at Libby. Alumina is low in the pyroxenites but high in most of the rocks; however, there is a deficiency in alumina relative to the alkalies and lime, as shown by the lack of anorthite in the feldspar 'and the presence of acmite in the pyroxene.

Iron is relatively high in the pyroxenites and ijolites. Magnesia is moderate. Lime is high, especially in the pyroxenites and ijolites; this accounts for the lack of orthopyroxene and the small amount of olivine. Soda is high in most of the rocks, whereas potash is moderate. Phosphate is high in nearly all. In some of the rocks zirconia, the rare earths, tantalum, and niobium occur in unusually large amount.

Succession of intrusions.-The authors describing most of the bodies listed in table 15 concluded that all the rocks were intruded nearly or quite simultaneously and that most of the differentiation or reaction took place after intrusion.

In Chibina the order is (1) hibenite with umptekites, etc., (2) aegirite-nepheline syenites, (3) nepheline syenites with pectolite and cancrinite, (4) ijolites and urtites, (5) lamprophyric dikes, (6) pyroxenites, ete.

For Magnet Cove, Landes ${ }^{30}$ states that the central part, consisting of ijolite and pyroxenite, was intruded first, and then the outer part, consisting of shonkinite, leucite porphyry, and foyaite.

At Libby the pyroxenite was the first intrurion, followed by the nepheline syenite and syenite. The granite was last.

At Iron Hill the succession of events is especially well shown. The contacts are sharp, and each intruding mass broke across the older rocks, which had already become completely or almost completely solidified. Possible exceptions have been noted along parts of the pyroxenite-ijolite contacts, where thin seams of nepheline cut pyroxenite that is soaked with nepheline. Even here the pyroxenite may have been completely crystalline when the nepheline magma was intruded. The succession of events was (1) emplacement of the marble; (2) intrusion of uncompahgrite; (3) intrucion of pyroxenite as a complex, with fine-grained varieties commonly after those of coarse grain, biotite-rich varieties after the biotite-poor varieties, apatite-rich rocks after the biotite-rich rocks, and iron ore as the last product of intrusion; (4) intrusion of ijolite; (5) intrusion of soda syenite; (6) intrusion of nepheline syenite; (7) intrusion of nepheline gabbro and quartz gabbro.

\section{ORIGIN OF THE ROCKS}

The twelve intrusive bodies briefly characterized in the preceding pages have so many features in common that a similar origin seems probable. In this section the origin of the Iron Hill stock, witl which I am personally familiar, is chiefly considered, but it is believed that the conclusions reached apply with some modifications, to most if not all of the other bodies.

Of the six stocks (Libby, Fen, Alnö, Magnet Cove, Jacupiranga, and Sekukuniland) that most closely resemble the Iron Hill stock, all but that of Libby have marble modes whose origin is difficult to explain. The very intimate association of marble with rocks extremely high in lime in the Iron Hill stock and in most of the similar stocks suggests assimilation of marble as a factor in the origin of these peculiar rocks. A simple and consistent explanation of the origin of all the rocks of the Iron Hill stock can be reached by postulating an original basaltic magma modified first by assimilation of marble and then by crystal differentiation.

${ }^{30}$ Landis, K. K., op. cit. (Am. Mineralogist, vol. 16), p. 321. 
Tilley and Harwood ${ }^{31}$ have shown that pyroxenerich rocks, nepheline rocks, and melilite rocks can be formed by the assimilation of limestone by dolerite. The reaction zones that they found were measured in feet or inches, and the contaminated magma remained practically where formed. Their rocks somewhat resemble but are not identical with the Iron Hill rocks. They conclude: "Rather is the Scawt Hill contact zone, with the very limited hybrid zone and dominance within it of pyroxene-rich dolerite and pyroxenite assemblages, to be taken as an example of the restricted potentiality of igneous magma to generate alkali types by assimilation." 32

Uncompahgrite.-The very high content in lime and low content in silica and alumina, together with the unusual body of marble in the midst of the Iron Hill stock, immediately suggest assimilation of limestone as the origin of the uncompahgrite. However, the exposed body of carbonate rock could not have furnished the material for the assimilation, as there is no relation between the composition of the igneous rocks and nearness to carbonate rock and no other indication of extensive assimilation in place. The assimilation must have taken place in depth and the only evidence furnished by the marble of Iron Hill is that it indicates an adequate source of carbonates. Taking 100 parts of Daly's average plateau basalt ${ }^{33}$ (column 1 , table 17, p. 41), adding $33 \frac{1}{3}$ parts of the bases of a limestone (27 parts $\mathrm{CaO}, 4 \frac{1}{3}$ parts $\mathrm{MgO}$, and 2 parts $\mathrm{SiO}_{2}$ ), and calculating the resulting rock to 100 percent gives a rock of the composition shown in column 2 of table 17 . In column 3 is given the average composition of the uncompahgrite. The uncompahgrite contains less alumina than that of the mixed rock, and a greater proportion of its iron is in the ferric state, but the two are otherwise very close. By adding a little more lime and crystallizing out a little anorthite the difference could be largely eliminated. A moderate change in the composition of the basalt and of the limestone assimilated would also give a better check. The table shows that the uncompahgrite could be derived from a basalt by the assimilation of about one-third of its weight of the bases of a dolomitic limestone.

The heat relations offer no serious difficulty. Some pyroxene and other minerals may have been precipitated as the carbonate was dissolved, thus furnishing their latent heat. The assimilation took place in depth and probably by only a small part of a large body of magma. We have ample evidence that in depth a magma may have some superheat, and a small amount of heat in a large body of magma may furnish the heat required for a relatively small part of the

${ }^{31}$ Tilley, C. E., and Harwood, H. F., The dolerite-chalk contact of Scawt Hill County Antrim; The production of basic alkali-rocks by the assimilation of limestone by basaltic magma: Mineralog. Mag. vol. 22, pp. 439-468, 1931.

a2 Idem, p. 467.

33 Daly, R. A., Igneous rocks and the depths of the earth, p. 17, McGraw-Hill Book Co.. 1933. magma to assimilate the carbonate. Even without superheat precipitation of a small amount of crystals in the whole magma might have furnished the raquired heat.

Pyroxenite.-If 10 parts of $\mathrm{CaO}, 2$ parts of $\mathrm{MgO}$, and 1 part of $\mathrm{SiO}_{2}$ are added to 100 parts of the average basalt and 40 parts of plagioclase $\left(\mathrm{Ab}_{39} \mathrm{An}_{61}\right)$ are removed by crystallization, the resulting rock would have the composition shown in column 4 of trible 17 . Column 5 gives the composition of the average pyroxenite of Iron Hill. Comparison of columns 4 and 5 shows that the chief differences are the state of oxidation of the iron and the high percentages of $\mathrm{TiO}_{2}$ and $\mathrm{P}_{2} \mathrm{O}_{5}$ in the pyroxenite. Here again, except for the $\mathrm{TiO}_{2}$ and $\mathrm{P}_{2} \mathrm{O}_{5}$, the pyroxenite could be derived from the assimilation of a moderate amount of limestone by a basalt, followed by crystal fractionation that removed about 40 percent of calcic feldspar. The removal of the plagioclase would extract alumina from the magma, and the added $\mathrm{CaO}$ would be sufficient to combine with all the available $\mathrm{MgO}$ and $\mathrm{FeO}$ and thus prevent the formation of orthopyroxene or olivine.

The plagioclase would probably crystallize as the carbonate was dissolved, and the latent heat of crystallization of 40 parts of plagioclase would be more than sufficient to supply the heat necessary to dissolve 13 parts of carbonate. ${ }^{34}$

In the preceding paragraph it was assumed that plagioclase would be the first mineral to crystallize from a magma of the composition of a basalt enriched in lime. This is by no means certain. Bowen ${ }^{35}$ has shown that in the simple system diopside-albiteanorthite diopside and plagioclase would crystallize together after the excess of one or the other over a definite amount had been precipitated. Howerer, the evidence from the rocks themselves has long boen accepted as showing that in diabase plagioclase crystallized first. The simple artificial system is not sufficiently close to the natural rocks to justify $u^{-}$in ignoring the evidence from the rocks themselves.

Petrographers should search for rocks that will give us the evidence. Typical basalts or diabases crilled at just the right stage in their crystallization should show whether or not the residual liquid is enriched in pyroxene. The rocks selected must be typical basalts and should not approach andesites in composition, as andesites clearly crystallize in a different way. ${ }^{33}$ If in diabases plagioclase crystallizes before pyroxene, our conclusions about magmatic differentiation must be modified. If the plagioclase and pyroxene crystallize together, Vogt's anchieutectic (or cotectic) nuust be accepted.

34 Bowen, N. L., The behavior of inclusions in igneous rocks: Jour. Gjology, vol. 30, pp. 514-520, 1922.

${ }^{35}$ Bowen, N. L., The crystallization of haplobasaltic, haplodiorite, and related magmas: Am Jour. Sci., 4th ser., vol. 40, pp. 166-168, 1915.

${ }^{36}$ Walker, F., The late Paleozoic quartz dolerites and tholeiites of Scotland: Mineralog. Mag., vol. 24, pp. 150-156, 1935 . 
TABLE 17.-Comparison of Iron Hill rocks with products formed by adding limestone to a basalt magma and allowing separation of crystals

\begin{tabular}{|c|c|c|c|c|c|c|c|c|}
\hline & 1 & 2 & 3 & 4 & 5 & 6 & 7 & 8 \\
\hline $\begin{array}{l}\mathrm{SiO}_{2-} \\
\mathrm{TiO}_{2-} \\
\mathrm{Al}_{2} \mathrm{O}_{3-} \\
\mathrm{Fe}_{2} \mathrm{O}_{3} \\
\mathrm{FeO}\end{array}$ & $\begin{array}{r}48.8 \\
2.2 \\
14.0 \\
3.6 \\
9.8\end{array}$ & $\begin{array}{r}38.4 \\
1.8 \\
10.5 \\
2.7 \\
7.4\end{array}$ & $\begin{array}{r}38.3 \\
1.9 \\
6.1 \\
6.9 \\
4.6\end{array}$ & $\begin{array}{r}39.8 \\
2.9 \\
3.6 \\
4.8 \\
13.1\end{array}$ & $\begin{array}{r}35.5 \\
7.4 \\
4.1 \\
9.4 \\
6.9\end{array}$ & $\begin{array}{r}46.9 \\
1.7 \\
23.7 \\
----\end{array}$ & $\begin{array}{r}47.9 \\
1.1 \\
22.6 \\
2.0 \\
4.8\end{array}$ & $\begin{array}{r}48.8 \\
1.2 \\
19.3 \\
1.9 \\
5.2\end{array}$ \\
\hline $\begin{array}{l}\mathrm{Fe} \text { as } \mathrm{FeO} \\
\mathrm{MgO} \\
\mathrm{CaO} \\
\mathrm{Na}_{2} \mathrm{O} \\
\mathrm{K}_{2} \mathrm{O} \\
\mathrm{P}_{2} \mathrm{O}_{5}\end{array}$ & $\begin{array}{r}13.0 \\
6.7 \\
9.4 \\
2.6 \\
.7 \\
.3\end{array}$ & $\begin{array}{r}9.8 \\
8.3 \\
27.3 \\
2.0 \\
.5 \\
.2\end{array}$ & $\begin{array}{r}10.8 \\
8.1 \\
29.0 \\
2.2 \\
.3 \\
.5\end{array}$ & $\begin{array}{r}17.4 \\
11.6 \\
19.7 \\
1.1 \\
.9 \\
.4\end{array}$ & $\begin{array}{r}15.3 \\
11.9 \\
19.7 \\
\text { 1. } 0 \\
1.3\end{array}$ & $\begin{array}{r}\text { 7. } 0 \\
2.2 \\
12.2 \\
3.8 \\
1.3 \\
.5\end{array}$ & $\begin{array}{r}6.6 \\
2.1 \\
12.1 \\
4.0 \\
.8 \\
1.0\end{array}$ & $\begin{array}{r}6.9 \\
4.7 \\
14.8 \\
3.5 \\
.4 \\
.2\end{array}$ \\
\hline
\end{tabular}

1. Average plateau basalt according to Daly. ${ }^{37}$

2. Average basalt to 100 parts of which have been added 20 parts $\mathrm{CaO}, 4 \frac{1}{3}$ parts of $\mathrm{MgO}$, and 2 parts of $\mathrm{SiO}_{2}$.

3. Average uncompahgrite of Iron Hill.

4. Average basalt to 100 parts of which have been added 10 parts of $\mathrm{CaO}, 2$ of $\mathrm{MgO}$, and 1 of $\mathrm{SiO}_{2}$ and then taken away 15 parts of albite and 23 parts of anorthite.

5. Average pyroxenite of Iron Hill.

6. Average basalt to 100 parts of which have been added $71 / 2$ parts of $\mathrm{CaO}$, and deducted 4 parts of magnetite, $2 \frac{1}{2}$ parts of ilmenite and 45 parts of pyroxene like that of the ijolite.

7. Average nepheline gabbro of Iron Hill.

8. Average basalt to 100 parts of which have been added 10 parts $\mathrm{CaO}, 2$ parts of $\mathrm{MgO}, 1$ part of $\mathrm{SiO}_{2}$ and 75 parts of labradorite.

Ijolite.-The ijolites differ chemically from the pyroxenites in their higher content of $\mathrm{Al}_{2} \mathrm{O}_{3}$ and alkalies and lower $\mathrm{TiO}_{2}$, iron, and $\mathrm{MgO}$; mineralogically they contain more nepheline and melanite and less pyroxene, magnetite, biotite, and perofskite. The different varieties of ijolite vary mineralogically chiefly in their nepheline and apatite content and in the reciprocal relations between augite and inclanite. Rare varieties (probably a part of the pyroxenite) contain sphene. (See table 9, p. 24.) Chemically, the chief variations, in percentages, are $\mathrm{Al}_{2} \mathrm{O}_{3}, 4$ to $18 ; \mathrm{MgO}, 0.7$ to $9 \frac{1}{2}$; $\mathrm{Na}_{2} \mathrm{O}, 1 \frac{1}{2}$ to $6.3 ; \mathrm{K}_{2} \mathrm{O}, 0.1$ to $3 ; \mathrm{TiO}_{2}, 0.3$ to 5.4 ; and $\mathrm{P}_{2} \mathrm{O}_{5}, 0.1$ to 3.1. (See table 9, p. 24.)

The field relations and laboratory study of the Iron Hill area indicate a close relation between the ijolite and pyroxenite. The nepheline facies of the pyroxenite is identical with pyroxene-rich ijolite. This nepheline pyroxenite is poor in biotite, as is most of the ijolite. There is every gradation between pyroxenite with no nepheline and ijolite. A moderate loss of pyroxene from the nepheline pyroxenite by crystal settling or some other means would yield the pyroxene ijolite.

The melanite ijolite could not be formed by simple crystal fractionation. Chemically it is characterized by high $\mathrm{Al}_{2} \mathrm{O}_{3}$, very high $\mathrm{Fe}_{2} \mathrm{O}_{3}$, and very low $\mathrm{MgO}$. The rock represented by the single analysis of melanite jolite has low $\mathrm{P}_{2} \mathrm{O}_{5}$. Mineralogically it is characterized

${ }^{37}$ Daly, R. A., Igneous rocks and the depths of the earth, p. 201, McGraw Hill Book Co., 1933. by the presence of much melanite, and it contains a little primary calcite.

The Iron Hill pyroxenite has the correct amount of $\mathrm{CaO}$ to give augite as the only pyroxene, no olivine, and much perofskite. The field and laboratory study shows that where the pyroxenite magma reacts with marble the addition of calcite results in the formation of melanite at the expense of perofskite, iron ore, $\varepsilon$, nd perhaps pyroxene and is accompanied by oxidation of iron. Further addition of calcite remains as calcite. Melilite forms only when calcite is added to a magma near a basalt in composition, as the pyroxenite does not contain the soda and alumina that are in the melilite.

Moreover, melanite is a very late or deuteric and in part hydrothermal mineral in all the rocks that contain it. In the ijolite the relative proportions of pyroxene and melanite vary greatly within very short distances.

Some possible ways of deriving the melanite ijolite from the pyroxenite or pyroxene ijolite are indicated below.

1. By further assimilation of calcite. Some melarite has been formed in the pyroxenite in this way. However, without the separation of crystals other than those to be expected-pyroxene and possibly iron ore and perofskite - the large decrease in $\mathrm{MgO}$ and increase in $\mathrm{Al}_{2} \mathrm{O}_{3}$, total iron, and $\mathrm{TiO}_{2}$ are not explained in this way.

2. The movement of material for the melanite by the gas transfer, as advocated by Fenner, may have played a part. Considerable amounts of melanite, clearly deposited from moving solutions, replaced the older minerals in nearly solid rock. However, the main melanite ijolite can hardly have been formed from the pyroxene ijolite in that way, as there is no evidence that the melanite has replaced pyroxene on a large scale, and the removal of the pyroxene would be necassary to form the melanite ijolite from the average ijolite.

3 . The concentration of the early crystals to separate from the magma in some places and of the residual liquid in others. If the crystallization had so proceeded th at most of the pyroxene and some of the nepheline had separated and left a residual liquid containing nepheline and much melanite enriched in mineralizers, the later crystallization of such a liquid would explain the facts. I have seen no direct evidence of this, but it fits well with the late to deuteric crystallization of the melanite and its common deposition by mineralizers. The large amount of melanite required to be in the residual inagma--over 50 percent of the resulting rock-is more than one would expect. However, this seems the most reasonable explanation.

Syenite and nepheline syenite.-The syenite could he,ve been derived by the separation of the residual liquid from the feldspar pyroxenite. This feldspar pyroxenite is partly in pegmatitic segregations in the nornal 
pyroxenite. The last material to crystallize from the feldspar pyroxenite was alkalic feldspar that had about the composition of the feldspar of the syenite. Similarly, the nepheline syenite might have been derived from some of the nepheline-feldspar pyroxenite. The syenite and nepheline syenite are normal soda-rich rocks, and they need not have been derived directly from the pyroxenite.

Nepheline gabbro.- The nepheline gabbro and quartz gabbro occur in associated dikes and are closely related. They must be related to the other alkalic rocks of the Iron Hill area, but they represent a subprovince within the main petrographic province. They are characterized by andesine or labradorite. The nepheline gabbro has little olivine or hypersthene in the norm and in this respect it resembles the other rocks of the Iron Hill stock and suggests the assimilation of calcite.

If the average basalt of Daly were to assimilate $71 / 2$ percent of $\mathrm{CaO}$ with the oxidation of some $\mathrm{FeO}$ and to lose by some method of crystal separation 4 percent of magnetite, $2 \frac{1}{2}$ percent of ilmenite and 45 percent of a pyroxene like that of the ijolite, it would have a composition (column 6 , table 17) almost identical with that of the nepheline gabbro (column 7 , table 17). If the diabasic structure of the nepheline gabbro resulted from simultaneous crystallization of feldspar and pyroxene, then a magma with a much larger amount of pyroxene would, on cooling, separate pyroxene until the liquid phase had about the composition of the nepheline gabbro.

However, the diabase structure may be due to early crystallization of plagioclase followed by that of pyroxene, and this is indicated by the flow structure of the plagioclase laths. Let us, then, consider again the postulated origin of the pyroxenite by the separation of labradorite crystals from a basaltic magma that had assimilated some marble. If we allow 75 parts of the labradorite crystals to settle into 100 parts of the hybrid magma, we get a magma that has a composition very much like that of the nepheline gabbro, as shown in column 8, table 17 .

An alternative origin for the pyroxenite and nepheline gabbro involves a reciprocal relation. That is the nepheline gabbro was the contaminated basaltic magma from which pyroxene, magnetite, and ilmenite crystals had settled, and the pyroxenite represents the accumulated crystals. The chief reason for preferring the explanation first given is that the plagioclase crystals of the nepheline gabbro were largely formed before the intrusion of the dikes, as indicated by their subparallel arrangement, whereas the pyroxene of the pyroxenite appears to have crystallized in place.

Quartz gabbro.-The quartz gabbro has a composition near that of the average basalt but grading slightly toward a diorite. Even the minor constituents, $\mathrm{TiO}_{2}$ and $\mathrm{P}_{2} \mathrm{O}_{5}$, are about normal for such a rock. It was probably derived from the primary basalt with little or no contamination and little differentiation.

Conclusions as to origin.-The conclusions from the foregoing discussion are summarized as follows: The very intimate association of marble with the Iron Hill alkalic rocks and the repetition of this intimate association in about half the similar petrographic provinces throughout the world, together with the extremely high content of lime in the Iron Hill stock and in those of most of the similar provinces, suggest assimilation of marble as a factor in the origin of these peculier rocks. A simple and consistent explanation of the origin of all the rocks of the Iron Hill area can be reached by postulating an original basaltic magma, modified by assimilation of marble followed by crystal diferentiation.

The assimilation of a moderate amount of marble by a basaltic magma would give a rock like the uncompahgrite; assimilation of marble by a basaltic magma, accompanied by separation of calcic plagioclase until nearly all the alumina was removed, would give the pyroxenite; and if these separated labradorite crystals were concentrated in another part of the contaminated magma, the nepheline gabbro would result. The ijolite, syenite, and nepheline syenite are related to the pyroxenite and could have been formed by semaration of pyroxene and perhaps other constituents from the pyroxenite magma. The quartz gabbro renresents the original basaltic magma slightly differentiated, as in ordinary lime-alkalic series.

Some corollaries to these conclusions follow. The carbonates reacted on by the original basalt to form the alkalic rocks must have been much richer in $\mathrm{CaCO}_{3}$ than the Iron Hill marble, or else the reaction was selective and dissolved $\mathrm{CaCO}_{3}$ to form the double silicates of calcium and magnesium rather than the silicates of either oxide alone. This is paralleled by the strong tendency in igneous rocks to form diopside if lime is available, instead of orthorhombic pyroxene, and the similar tendency during metamorphism to form diopside from impure magnesian limestone, leaving pure calcite as the final carbonate. As the $\mathrm{CaO}$ of the calcite combined with the silica and other oxides of the magma, the $\mathrm{CO}_{2}$ must have escaped, at least in part. This is similar to the escape of $\mathrm{CO}_{2}$ during the formation of lime silicates from impure limestones during metamorphism, and the rate of such escape probab] ro determines the rate of the reactions, both during retamorphism and during reaction of magma with cerbonate rocks. Such geologic processes take place in systems that are more or less leaky.

If the unusual rocks of the Iron Hill area had the origin that I propose as most probable, the earl' effects of the assimilation of carbonate rock by a basaltic magma were to convert normative hypersthene to diopside, to form perofskite from the $\mathrm{TiO}_{2}$, thus freeing $\mathrm{FeO}$ 
for diopside, to oxidize some of the iron, and to convert most of the normative orthoclase and olivine to biotite. This last-named reaction is indicated by the facts that practically all the $\mathrm{K}_{2} \mathrm{O}$ and $\mathrm{Al}_{2} \mathrm{O}_{3}$ of the rocks is in the biotite and that olivine is practically absent from the rocks, in spite of its abundance in the norm of the biotite-bearing rocks. The formation of biotite no doubt required abundant mineralizers. From this liquid the pyroxenite was formed by separating crystals of labradorite. On further addition of $\mathrm{CaO}$ to this liquid melilite was formed with pyroxene, perofskite, and some biotite. The melilite of Iron Hill (p. 45) has about the composition of 100 parts plagioclase $\left(\mathrm{Ab}_{7} \mathrm{An}_{3}\right)$, 50 parts diopside, and 50 parts $\mathrm{CaO}$. A final stage in the formation of uncompahgrite is the formation of melanite by oxidation of iron in diopside or some similar silicate and addition of $\mathrm{CaO}$. In spite of the extremely low silica content of the magma, olivine did not form. The unique small bodies of olivine pyroxenite, which contain melilite and much olivine, may be due to assimilation of dolomite instead of calcite.

A study of the contacts of the pyroxenite with carbonate inclusions shows that the pyroxene magma does not react readily with $\mathrm{CaCO}_{3}$ except by oxidation of iron and formation of melanite, but it does dissolve $\mathrm{CaCO}_{3}$. Diopside, therefore, appears to be persistent unless there is feldspar as well as $\mathrm{CaO}$ present to combine with it and form melilite.

Whatever assimilation has taken place must have occurred at depth, before the magmas reached their present positions. There is at most a zone of only a few inches next to marble inclusions that shows evidence of assimilation, and the rocks are the same next to marble as they are next to granite.

The greatest weakness of the postulated theory for the origin of the Iron Hill and similar petrographic provinces is its failure to account for the high $\mathrm{TiO}_{2}$ and $\mathrm{P}_{2} \mathrm{O}_{5}$. In nearly all the provinces both these constituents are high and in some they are very high.

\section{MINERALOGY}

By Esper S. Larsen and William F. Jenks

The purpose of this section is to record detailed data on some of the minerals and, more particularly, to bring out the similarities and differences of the minerals in the different rocks and different associations.

The number of minerals found is relatively few, but some minerals are unusually abundant or occur in unusually large grains. Melilite, in cleavage pieces 1 foot across, is probably the most striking mineral. Perofskite is abundant in large grains, melanite is abundant, and good pieces of nepheline can be found. An unusual series of sodic amphiboles grading from soda tremolite to glaucophane is widespread. Juanite, cebollite, and sulfatic cancrinite, as well as soda tremolite, were first described from their occurrence in this area.

\section{SULFIDES}

The chief sulfide of the area is pyrite, which is present in the marble, in small amount in the veins, and elsewhere. There is probably some pyrrhotite. Galena, chalcopyrite, and sphalerite are subordinate minerals in the border zones of the marble veins. Some sulfides have no doubt been oxidized, but they appear not to be abundant in the area.

\section{FLUORITE}

Fluorite is present chiefly in veins associated with carbonates, and it is not abundant. A deep-purple to nearly black variety, gunnisonite, ${ }^{38}$ is present in considerable amount in some veins in the upper drainage of Deldorado Creek. Under the microscope this fluorite is strongly zoned, with alternate thin zones that are dark purplish to those that are nearly colorless. It becomes white on heating.

\section{QUARTZ}

Quartz is a rare mineral in the Iron Hill area. It is present as a very rare constituent in some of the pegmatitic varieties of feldspar pyroxenite and as an essential though minor constituent in the quartz gablro. It is also present in some of the hydrothermal deposits, but in these it is relatively subordinate and is usurlly associated with feldspar.

\section{SPINEL}

Green spinel with a variable index of refraction aroraging 1.75, and hence an iron-poor pleonaste, has boen found in the small limestone inclusion that is between the forks of Sammons Gulch.

\section{OXIDES OF TITANIUM}

Anatase is a widespread mineral in tiny crystals in the contact-metamorphic zone of the marble and a a secondary mineral in other parts of the area. Good crystals of blue anatase embedded in limonite (probably an oxidation of sulfide) are present in a network of seams that cut a diorite dike above the Lot mine, about 2 miles north of the Iron Hill stock. ${ }^{39}$

\section{IRON OXIDES}

Magnetite, associated with perofskite and a little ilmenite, is an abundant primary mineral in the pyroxenite and to a less extent in the other igneous rocks. The "iron ore" in these rocks is about balf magnetite.

Hematite is present in some of the "iron ores" of the limestone. The variety martite, a pseudomorph af magnetite is abundant as drusy crystals associated with

38 Clarke, F. W., and Perry, N. W., A new mineral from Colorado (gunnison'te); Am. Chem. Jour., vol. 4, pp. 140-142, 1881.

39 Larsen, E. S., and Hunter, J. F., Melilite and other minerals from Gunrison County, Colo.: Washington Acad. Sci. Jour., vol. 4, p. 479, 1914. 
apatite, calcite, and some silicates in a few veins cutting the marble north of Beaver Creek.

Limonite and related minerals are widespread but occur in rather small amount in the marble and elsewhere.

\section{CARBONATES}

Carbonates form a considerable part of the rocks of the Iron Hill area. They make up nearly all the. marble of Iron Hill and the smaller inclusions nearby, most of the hydrothermal bodies in the surrounding granite, numerous veins in the Iron Hill stock, and they are present in small amount as primary minerals in the pyroxenite, ijolite, and other igneous rocks of the Iron Hill stock, and as hydrothermal and weathering products in all the rocks.

Dolomite, with more or less iron content, is by far the chief carbonate, as it is the chief mineral of the marble inclusions of Iron Hill and elsewhere, of the bodies of marble in the granites, and of the veins of carbonate.

Calcite is less abundant in the bodies named above, but it is the carbonate in most of the contact-metamorphic lime-silicate zones and in some of the late hydrothermal products and is the magmatic carbonate in the igneous rocks. Calcite is present in the marble veins chiefly where there is hastingsite or other silicates in the vein.

In some veins and in some parts of the marble of Iron Hill the dolomite gives place to ankerite.

\section{BRUGNATELITTE}

A micaceous mass of nearly colorless brugnatellite, a hydrous carbonate and hydroxide of magnesium and ferric iron, was found as an alteration of the melilite in small amount and in a few places, especially in the lower part of the gully south of Beaver Creek and half a mile above the wagon road. It is present in veinlike streaks, and as it is very soft it may be fairly common but rarely exposed. It is associated with a little calcite and hornblende and is probably a late hydrothermal mineral. Its optical properties are as follows: Optically negative, $2 \mathrm{~V}$ very small, $\omega=1.538, \epsilon=1.516$.

\section{FELDSPAR}

Lime-soda feldspar.-Plagioclase carrying considerable amounts of lime is rare in the Iron Hill stock and is confined to the final dike phase of the intrusions. That of the nepheline gabbro is labradorite $\left(\mathrm{Ab}_{38} \mathrm{An}_{62}\right)$; that of the quartz gabbro is labradorite $\left(\mathrm{Ab}_{45} \mathrm{An}_{55}\right)$.

Albite, microcline, and orthoclase.-Microcline-microperthite is the chief constituent of the syenite and nepheline syenite and is rare in the pyroxenite. Microcline, orthoclase, and albite are present in the pyrox- enite, and albite and orthoclase in the metamorphosed marble and in the veins.

The albite in all the rocks is surprisingly uniform in composition. The $\alpha$ index of refraction was measured on about 20 specimens from the veins, metamorphosed marble, and various igneous rocks. It rang $>$ from 1.529 to $1.531-a$ range which is within the limit of error of the measurements and indicates an albite with 5 percent of anorthite.

The potash feldspars show more variation. Those from the metamorphic marble and veins have lower indices of refraction than those from the igneous rocks and agree with adularia. Those in the pyroxerites are chiefly orthoclase of rather uniform properties and are rich in soda. Many of them are glassy and resemble sandine. The orthoclase is all optically negative and has a moderate to large axial angle. The microcline from the pyroxenites also appears to be relatively rich in soda; that of the microperthite in the soda syenite has lower indices of refraction and is probably lower in soda. Partial optical data for several typical feldspars are given below.

\begin{tabular}{|c|c|c|c|c|}
\hline & $\boldsymbol{\alpha}$ & $\beta$ & $\boldsymbol{\gamma}$ & Orien'ation \\
\hline $\begin{array}{l}\text { Orthoclase: } \\
\text { Pyroxenite.. } \\
\text { Hydrothermal. } \\
\text { Microcline: } \\
\text { Pyroxenite. } \\
\text { Soda syenite.... }\end{array}$ & $\begin{array}{l}1.523 \\
1.518 \\
1.527 \\
1.520\end{array}$ & $\mid$\begin{tabular}{c}
1.528 \\
\hdashline$\ldots$ \\
\end{tabular} & $\begin{array}{l}1.531 \\
1.524 \\
1.533 \\
1.527\end{array}$ & $\begin{array}{l}\mathrm{Z}=\mathrm{b}, \underset{\mathrm{X}}{\mathrm{X} \wedge \mathrm{a}=6^{\circ} .} \\
\text { Adularia. }\end{array}$ \\
\hline
\end{tabular}

Nepheline makes up about a third and locally a much greater part of the ijolite. It is an essential mineral of the nepheline syenite and nepheline gabbro and is present locally in the pyroxenite. In the ijolite of the hill between the forks of Beaver Creokfresh nepheline in fragments several inches across can be collected, and even larger pieces might be had by a little trenching, as the material near the surface is broken into fragments by weathering. The indices of refraction of the nepheline from the analyzed ijolite (U-2011) are $\omega=1.545, \epsilon=1.540$, and those from other specimens of the ijolite $\omega=1.543, \epsilon=1.537$.

\section{MELILITE}

Melilite makes up about 68 percent of the uncompahgrite. In part it is very coarse-grained, and cleavage pieces 1 foot across are common. An analysis of coarse melilite by $W$. T. Schaller, corrected for a few percent of impurities, follows. ${ }^{40}$

${ }^{40}$ Larsen, E. S., and Hunter, J. F., Melilite and other minerals from Gunnison County, Colo.; Washington Acad. Sci. Jour., vol. 4, pp. 474-477, 1914. 
Analysis of melilite

\begin{tabular}{|c|c|c|c|}
\hline $\mathrm{SiO}_{2} \ldots \ldots \ldots$ & 44. 13 & $\mathrm{BaO}_{\ldots}$ & .03 \\
\hline $\mathrm{Al}_{2} \mathrm{O}_{3}$ & 10.80 & $\mathrm{SrO}$ & .82 \\
\hline $\mathrm{FeO}$ & 2. 04 & $\mathrm{H}_{2} \mathrm{O}$ & .49 \\
\hline $\mathrm{MnO}_{\ldots} \ldots \ldots$ & .16 & & \\
\hline $\mathrm{MgO}_{\ldots}$ & 4. 35 & & 100. 03 \\
\hline $\mathrm{aO}$ & 33. 81 & Specific gravity & 2. 98 \\
\hline $\mathrm{Na}_{2} \mathrm{O}$ & 3. 40 & $\omega \mathrm{Na}$ & 1. 6323 \\
\hline $\mathrm{K}_{2} \mathrm{O}$ & Tr. & $\epsilon \mathrm{Na} \ldots \ldots . .$. & 1. 6257 \\
\hline
\end{tabular}

The optical properties of the mineral vary somewhat. It is mostly optically negative, but the birefringence varies somewhat and passes through a zero value and rarely the mineral is optically positive.

\section{PYROXENES}

Orthorhombic pyroxenes are entirely lacking in the Iron Hill stock. The monoclinic pyroxenes are by far the most abundant mimerals in the stock, and they vory considerably in composition and in mode of origin. For many of them the optical properties have been determined. Some of the data are given in table 18 . The pyroxenes in nearly all the analyzed rocks are included in this table.

TABLE 18.-Optical properties of pyroxenes from Iron Hill, Colo.

\begin{tabular}{|c|c|c|c|c|c|c|c|}
\hline \multicolumn{8}{|c|}{ Igneous pyroxenes } \\
\hline Specimen No. & Rock & $\alpha$ & $\beta$ & $\gamma$ & Birefringence & $2 \mathrm{~V}$ & $\mathrm{z} \wedge \mathrm{c}$ \\
\hline $\mathrm{U}-27 \ldots$ & Uncompahgrite & 1. 682 & 1. 689 & 1.715 & 0.033 & Med ........ & 44 \\
\hline $\mathrm{U}-2015^{1}$ & Uncompahgrite, fine & 1. 686 & 1. 696 & 1. 717 & .031 & $50 \pm \ldots \ldots$ & 40 \\
\hline $\mathrm{U}-718^{1}--$ & Uncompahgrite, coarse & 1. 691 & 1. 701 & 1. 721 & .030 & Lge....... & 49 \\
\hline $\mathrm{IH}-3251$ & Olivine pyroxenite & 1. 685 & 1. 693 & 1. 711 & .026 & $66 \ldots \ldots \ldots$ & 41 \\
\hline $\mathrm{IH}-1011$ & Coarse pyroxenite & 1. 688 & 1. 697 & 1. 719 & 031 & $65 \pm \ldots \ldots$ & 43 \\
\hline $\mathrm{U}-1199$ & Fine pyroxenite & 1. 691 & 1. 698 & 1. 720 & .029 & 52 & 41 \\
\hline $\mathrm{U}-11921$ & Biotite-iron ore of pyroxenite & 1. 697 & 1. 706 & 1. 726 & .029 & Med....... & 41 \\
\hline $\mathrm{IH}-210$ & Pyroxenite dike in marble & 1. 706 & 1. 713 & 1. 734 & 028 & $61 \pm \ldots \ldots$. & 47 \\
\hline $\mathrm{U}-1195 \ldots$ & Pyroxenite with feldspar & 1. 708 & 1. 717 & 1. 737 & .029 & 61 & 42 \\
\hline $\mathrm{U}-744$ & Pyroxenite. & 1. 708 & 1. 721 & 1. 743 & 035 & 73 & 65 \\
\hline & Pyroxenite thin seam & 1. 716 & 1. 738 & 1. 758 & 042 & & \\
\hline $\mathrm{U}-213812$ & Pyroxenite with feldspar and nepheline.... & 1. 720 & 1. 732 & 1. 752 & 032 & $74 \ldots \ldots$ & 67 \\
\hline $\mathrm{H}-2133$. & Tjolite, sphene & 1. 693 & 1. 703 & 1. 721 & .028 & Lge & 42 \\
\hline $\mathrm{IH}-129^{2}$ & Ijolite pyroxene analyzed & 1. 693 & 1. 701 & 1. 722 & 029 & $63 \ldots \ldots$ & 45 \\
\hline $\mathrm{U}-1877^{1}$ & Ijolite, fine pyroxene & 1. 695 & 1. 702 & 1. 719 & .024 & Lge & $4 ?$ \\
\hline $\mathrm{U}-1132^{1}$ & Ijolite & 1. 702 & 1. 709 & 1. 729 & .027 & $65 \pm \ldots$ & 41 \\
\hline $\mathrm{U}-20111$ & & 1. 703 & 1. 711 & 1. 730 & .027 & Med & 42 \\
\hline U-903 & Syenite. & 1. 700 & 1. 708 & 1. 724 & .024 & Med. Ige & $4 ? 1 / 2$ \\
\hline $\mathrm{U}-2106^{1}$ & Gneissoid syenite & 1.729 & 1. 747 & 1. 767 & 038 & Lge. & $7^{3}$ \\
\hline $\mathrm{U}-1143^{2}$ & Banded syenite & 1. 730 & 1. 748 & 1. 768 & .038 & $90 \ldots$ & 76 \\
\hline $\mathrm{U}-14811^{1}$ & Nepheline syenite & 1. 734 & 1. 751 & 1. 772 & 038 & Lge. & 87 \\
\hline $\mathrm{U}-1172$ & Nepheline gabbro & 1. 694 & 1. 702 & 1. 722 & .028 & $64 \ldots \ldots \ldots$ & 41 \\
\hline $\mathrm{U}-1133$ & 1 & 1. 700 & 1. 705 & 1. 726 & .026 & $\mathrm{Sm}$ & $4 ?$ \\
\hline $\mathrm{IH}-3011$ & Quartz gabbro & 1. 691 & 1. 698 & 1. 718 & .027 & 64 to $\mathrm{sm}$ & $421 / 2$ \\
\hline $\mathrm{U}-931$ & _. & 1. 698 & 1. 703 & 1. 725 & .027 & $\mathrm{Sm}$ & 42 \\
\hline
\end{tabular}

Hydrothermal pyroxenes

\begin{tabular}{|c|c|c|c|c|c|c|c|}
\hline U-1928_.- & $\begin{array}{l}\text { Diopside idocrase rock (altered melilite) } \\
\text { Green pyroxene with hastingsite in altered } \\
\text { uncompahgrite. }\end{array}$ & $\begin{array}{l}\text { 1. } 667 \\
\text { 1. } 672\end{array}$ & $\begin{array}{l}\text { 1. } 675 \\
\text { 1. } 680\end{array}$ & $\begin{array}{l}\text { 1. } 696 \\
\text { 1. } 701\end{array}$ & $\begin{array}{r}0.029 \\
.029\end{array}$ & Med- & 41 \\
\hline IH-124_.... & Calcite vein, uncommon & 1. 685 & 1. 696 & 1. 713 & .028 & & 49 \\
\hline U-2004:- & 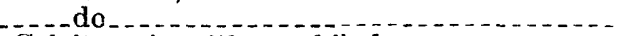 & 1. 684 & 1. 695 & 1. 713 & .029 & 76 & 40 \\
\hline IH-33_-. & Calcite vein with amphibole & 1. 757 & 1. 792 & 1. 808 & .051 & Opt. $-66 \ldots$ & $8 ?$ \\
\hline U-1913 & Metamorphosed marble with amphibole & 1. 765 & 1. 79 & 1. 81 & \pm .045 & Opt.-large.. & 9? \\
\hline U-937_... & $\begin{array}{l}\text { With amphibole in hydrothermally altered } \\
\text { granite. }\end{array}$ & 1. 754 & 1. 77 & 1. 796 & .042 & Opt.-large & 87 \\
\hline
\end{tabular}

1 Pyroxene from analyzed rock.

2 Pyroxene analyzed.

An analysis of pyroxene from the ijolite is given in column 1 of table 19, one of pyroxene from a feldsparnepheline pyroxenite in column 6 , one of aegirite from the syenite in column 7 , and composition of five other pyroxenes calculated from the rock analyses by deducting the other minerals as determined quantitatively.
These calculated analyses should be very near the trie composition, as pyroxene made from 63 to 79 percent of the rocks and the impurities were mostly magnetite, ilmenite, perofskite, nepheline, sphene, and feldsper. An analysis of a pyroxene from Salem Neck, Mass., is given in column 8 for comparison. 
TABLE 19.-Composition, optical properties, and other features of pyroxenes from Iron Hill, Colo.

Composition and optical properties

\begin{tabular}{|c|c|c|c|c|c|c|c|c|c|c|}
\hline & 1 & 2 & 3 & 4 & 5 & 6 & $6 a$ & $6 \mathrm{~b}$ & 7 & 8 \\
\hline 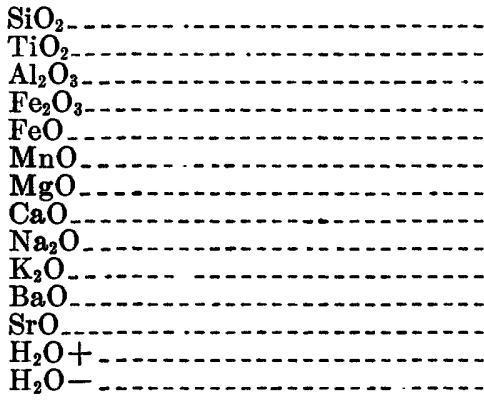 & $\begin{array}{r}49.80 \\
.70 \\
1.69 \\
3.64 \\
5.46 \\
.10 \\
12.75 \\
24.34 \\
1.00 \\
\text { Tr. } \\
.00 \\
.08 \\
\text { Tr. } \\
.60\end{array}$ & $\begin{array}{r}53.0 \\
.2 \\
3.6 \\
2.9 \\
2.5 \\
15.8 \\
22.7 \\
.6 \\
\hdashline .5\end{array}$ & $\begin{array}{r}48.6 \\
.6 \\
2.9 \\
6.6 \\
2.4 \\
14.1 \\
23.1 \\
.8\end{array}$ & $\begin{array}{r}50.1 \\
2.6 \\
3.0 \\
4.1 \\
5.8 \\
10.4 \\
22.1 \\
.5 \\
1.0\end{array}$ & $\begin{array}{r}51.6 \\
.4 \\
3.0 \\
4.3 \\
5.0 \\
.21 / 2 \\
12.3 \\
22.8 \\
.5 \\
.2 \\
\end{array}$ & $\begin{array}{r}48.98 \\
.66 \\
3.46 \\
8.52 \\
10.43 \\
.28 \\
5.84 \\
18.18 \\
2.78 \\
.68 \\
.22 \\
.04 \\
.18\end{array}$ & $\begin{array}{r}48.85 \\
.66 \\
3.35 \\
8.58 \\
10.52 \\
.28 \\
5.88 \\
18.32 \\
2.77 \\
.60 \\
.22 \\
.04 \\
.18\end{array}$ & $\begin{array}{r}46.5 \\
-2.9 \\
10.1 \\
11.1 \\
6.3 \\
22.0 \\
.6 \\
1.0\end{array}$ & $\begin{array}{r}49.73 \\
.82 \\
4.25 \\
11.95 \\
9.87 \\
.38 \\
3.82 \\
13.30 \\
5.45 \\
.40 \\
.05 \\
\text { None } \\
.09 \\
\end{array}$ & $\begin{array}{r}48.38 \\
1.45 \\
4.51 \\
3.43 \\
17.35 \\
\text { nd } \\
3.18 \\
18.07 \\
\text { 3. } 30 \\
.44 \\
\end{array}$ \\
\hline & 100. 16 & 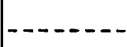 & .... & $\ldots$ & 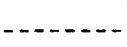 & 100. 25 & 100.25 & $\ldots$ & 100.11 & 100. 46 \\
\hline${ }_{\mathrm{Z}} \gamma_{\mathrm{V}} \mathrm{V}_{\mathrm{c}}$ & $\begin{array}{r}\text { 1. } 693 \\
\text { 1. } 701 \\
\text { 1. } 722 \\
63 \\
45\end{array}$ & $\begin{array}{r}\text { 1. } 691 \\
\text { 1. } 698 \\
\text { 1. } 720 \\
52 \\
41\end{array}$ & $\begin{array}{r}1.688 \\
1.697 \\
1.719 \\
\pm 65 \\
43\end{array}$ & $\begin{array}{r}\text { 1. } 693 \\
\text { 1. } 703 \\
\text { 1. } 721 \\
\text { Lge. } \\
42\end{array}$ & $\begin{array}{l}\text { 1. } 695 \\
\text { 1. } 702 \\
\text { 1. } 719 \\
\text { Lge. } \\
40\end{array}$ & & $\begin{array}{r}\text { 1. } 720 \\
\text { 1. } 732 \\
\text { 1. } 752 \\
74 \\
62\end{array}$ & & $\begin{array}{r}\text { 1. } 730 \\
\text { 1. } 748 \\
\text { 1. } 768 \\
90 \\
76\end{array}$ & $\begin{array}{r}1.72 \\
1.73 \\
1.75 \\
75-80 \\
58-63\end{array}$ \\
\hline Specific gravity & 3. 35 & & & & $\ldots . .-$ & & 3. 501 & & 3. 516 & 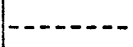 \\
\hline
\end{tabular}

\begin{tabular}{|c|c|c|c|c|c|c|c|c|}
\hline \multicolumn{9}{|c|}{ Atomic proportions } \\
\hline $\begin{array}{l}\mathrm{O} \\
\mathrm{Si}+\mathrm{Ti} \\
\mathrm{Al}+\mathrm{Fe}^{\prime \prime \prime} \\
\mathrm{Fe}^{\prime \prime}+\mathrm{Mg} \\
\mathrm{Ca} \\
\mathrm{Na}+\mathrm{K}\end{array}$ & $\begin{array}{r}24 \\
7.5 \\
.7 \\
3.5 \\
3.9 \\
.3\end{array}$ & $\begin{array}{r}24 \\
7.8 \\
.7 \\
3.8 \\
3.6 \\
.2\end{array}$ & $\begin{array}{r}24 \\
\text { 7. } 4 \\
\text { 1. } 3 \\
\text { 3. } 6 \\
\text { 3. } 7 \\
.2\end{array}$ & $\begin{array}{r}24 \\
\text { 7. } 9 \\
1.0 \\
\text { 3. } 1 \\
\text { 3. } 6 \\
.1\end{array}$ & $\begin{array}{r}24 . \\
\text { 7. } 7 \\
\text { 1. } 0 \\
\text { 3. } 4 \\
\text { 3. } 6 \\
.1\end{array}$ & $\begin{aligned} & 24 \\
& 7.6 \\
& 1.6 \\
& \text { 2. } 7 \\
& \text { 3. } 1 \\
& \text { 1. } 0\end{aligned}$ & $\begin{array}{r}24.7 \\
7.7 \\
2.1 \\
2.2 \\
2.2 \\
1.7\end{array}$ & $\begin{array}{r}24 \\
7.8 \\
\text { 1. } 2 \\
\text { 3. } 0 \\
\text { 3. } 0 \\
\text { 1. } 1\end{array}$ \\
\hline $\mathrm{Mg}_{\mathrm{Fe}} \mathrm{Fg}^{\prime \prime}$ & 4 & 10 & 11 & 3. 2 & 4 & 1. 0 & .65 & .3 \\
\hline$\frac{\mathrm{Al}}{\mathrm{Fe}^{\prime \prime \prime}}$ & .7 & .6 & .7 & 1. 1 & 1. 1 & .6 & .56 & 2. 1 \\
\hline
\end{tabular}

Theoretical molecules

\begin{tabular}{|c|c|c|c|c|c|c|c|c|}
\hline $\begin{array}{l}\mathrm{CaO} . \mathrm{MgO} \cdot 2 \mathrm{SiO}_{2} \\
\mathrm{CaO} . \mathrm{FeO} .2 \mathrm{SiO}_{2} \\
\mathrm{Na}_{2} \mathrm{O} . \mathrm{Fe}_{2} \mathrm{O}_{3} .4 \mathrm{SiO}_{2} \\
\mathrm{Na}_{2} \mathrm{O} . \mathrm{Al}_{2} \mathrm{O}_{3} .4 \mathrm{SiO}_{2} \\
\mathrm{CaO} \cdot \mathrm{SiO}_{2} \\
\mathrm{Na}_{2} \mathrm{O} \cdot \mathrm{SiO}_{2}\end{array}$ & $\begin{array}{r}68.9 \\
19.4 \\
7.4 \\
4.4 \\
-7\end{array}$ & \begin{tabular}{r}
82.7 \\
7.9 \\
3.7 \\
\hdashline-1.2 \\
-19
\end{tabular} & $\begin{array}{r}79.9 \\
8.7 \\
6.0 \\
-.8 \\
-9-\end{array}$ & 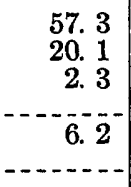 & $\begin{array}{r}66.5 \\
18.1 \\
3.2 \\
-2.6 \\
\end{array}$ & $\begin{array}{c}\text { 31. } 3 \\
37.0 \\
25.4 \\
3.9 \\
\end{array}$ & $\begin{array}{r}20.5 \\
35.3 \\
34.7 \\
6.8 \\
\hdashline\end{array}$ & $\begin{array}{r}17.3 \\
59.8 \\
9.7 \\
5.7 \\
-2.8\end{array}$ \\
\hline $\begin{array}{l}\mathrm{Al}_{2} \mathrm{O}_{3} \\
\mathrm{Fe}_{2} \mathrm{O}_{3} \\
\mathrm{TiO}_{3} \mathrm{~T}_{2} \\
\mathrm{H}_{2} \mathrm{O}_{2} \mathrm{O}_{2} \\
\text { Silica }\end{array}$ & $\begin{array}{r}1.7 \\
1.3 \\
-3.6 \\
-3.4\end{array}$ & $\begin{array}{c}3.6 \\
+1.8\end{array}$ & $\begin{array}{r}2.9 \\
4.5 \\
-3.5\end{array}$ & $\begin{array}{r}3.0 \\
3.3 \\
2.6 \\
+4.8\end{array}$ & $\begin{array}{r}3.0 \\
3.3 \\
.4 \\
+2.6\end{array}$ & $\begin{array}{c}3.2 \\
-1.3\end{array}$ & $\begin{array}{r}2.5 \\
-.1 \\
-.2\end{array}$ & 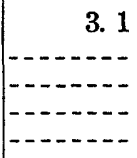 \\
\hline
\end{tabular}

1. Pyroxene from ijolite (IH-129). Iron Hill area, Colo. W. H. Herdsman, analyst.

2. Pyroxene from fine-grained pyroxenite (U-1199). Calculated from rock analysis. For rock analysis and mode see column 1, table 7 (p. 20).

3. Pyroxene from coarse-grained pyroxenite (IH-101). Calculated from rock analysis. Rock analysis and mode in column 2 , table 7.

4. Pyroxene from sphene-nepheline pyroxenite (U-2133). Calculated from rock analysis. Rock analysis and mode in column 7 , table 7 .

5. Pyroxene from nepheline pyroxenite (melteigite, U-1877). Calculated from rock analysis. Rock analysis and mode in column 5 , table 7 .

6. Pyroxene from feldspar-nepheline pyroxenite (shonkinite, U-2138). F. A. Gonyer, analyst. Compare the composition calculated from the rock analysis in column $6 \mathrm{~b}$. 6a. Pyroxene of 6 calculated free of $3 / 4$-percent feldspar.

6b. Pyroxene from feldspar-nepheline pyroxenite (shonkinite, U-2138). Calculated from rock analysis. Rock analysis and mode in column 6 , table 7 .

7. Aegirite (U-1143) from banded syenite. PJnochroism strong: in normal section $\alpha=$ dark grass green, $\beta=$ grass green, $\gamma=$ pale greenish yellow. F. A. Gonyer, analyst.

8. Acmitic diopsidic hedenbergite, Salem Neck, Mass. H. S. Washington, analyst. Washington, H. S., and Merwin, H. E., The acmitic pyroxenes: Am. Mineralogist, vol. 12, pp. 249-252, 1927.

A study of the tables shows that the prinary pyroxenes of nearly all the igneous rocks except the nepheline syenites and syenites are augite and show only a moderate variation in optical properties. The index of refraction, $\beta$, ranges from 1.682 to 1.714 or 
rarely higher. The indices of refraction of the pyroxenes in the uncompahgrites appear to be a little lower and of those in the ijolites and syenites a little higher to much higher than the average. The pyroxenes of some of the thin veinlets of pyroxenite have much higher indices of refraction and are richer in iron than usual, as is also the pyroxene from some but not all of the feldspar-bearing pyroxenites. That from the analyzed feldspar-nepheline pyroxenite (shonkinite) has especially high indices of refraction. An analysis of this pyroxenite (column 6, table 19) shows that it is rich in iron and has some soda. This pyroxene has optical properties like those of the acmiticdiopsidic hedenbergite from Salem Neck, Mass., as shown in table 19 , but chemically it has much more ferric iron and correspondingly less ferrous iron. The optical properties of the Salem Neck pyroxene indicate a much higher $\mathrm{Fe}_{2} \mathrm{O}_{3}$ content than is shown in the analysis, and the $\mathrm{Fe}_{2} \mathrm{O}_{3}$ and $\mathrm{FeO}$ are believed to be incorrect in this analysis. The composition of the pyroxene as calculated from the Rosiwal determination and the rock analysis gives a satisfactory check with the actual mineral analyses when allowance is made for the fact that the altered nepheline was calculated as nepheline.

The analysis and the mode of the quartz gabbro make it necessary that the pyroxene in this rock contain much clinohypersthene and be a pigeonite in composition, and the small but variable axial angles confirm this determination.

Some of the pyroxenes of the gneissoid syenite have high indices of refraction, and some that are clearly hydrothermal and are associated with secondary amphibole are aegirite, like the other hydrothermal aegirite.

The pyroxene from the nepheline syenite appears to have more iron, probably partly in acmite, than those of the other igneous rocks. It is not very different optically from the pyroxene of the nepheline-feldspar pyroxenite. Its optical properties are those commonly assigned to aegirite.

The pyroxene formed by the hydrothermal alteration of the melilite is a white and nearly pure diopside. A pale-green pyroxene associated with hastingsite and formed with it by hydrothermal alteration of augite is a diopside with about 8 percent of hedenbergite.

A very little of the pyroxene of the carbonate veins is diopside much like that of the igneous rocks but.with considerably larger axial angle. However, by far the greater part of the pyroxene of the carbonate veins and of the metamorphosed marble is an aegirite of rather uniform composition whose index of refraction, $\alpha$, ranges on about 20 measured specimens from 1.757 to 1.765 , and a single measurement gave 1.78. This same aegirite is present coating fractures and as a secondary mineral in the granite, syenite, and other rocks, in the limestone bodies in the pre-Cambrian rocks surrounding the stock, and in nearly all the hydrothermal deposits of the area. It is nearly everywhere associated with amphibole. The optical properties indicate a mineral near the aegirite from Brevik, Norway, which has the composition, in percentages, acmite 81 , hedenbergite 7 , jadeite 5 , and miscellaneous 7 .

The data on the preceding pages lead to the following conclusions:

1. The strictly igneous pyroxenes are augites with a little acmite, with the exception of those in the syenite, nepheline syenite, and feldspathic and other roxe varieties of the pyroxenite, which are aegirite, and that of the quartz gabbro, which is pigeonite.

2. There is little difference between the common pyroxenes of the different igneous rocks. All a re augites with low soda and moderate iron content.

3. Rare pyroxenes of some small contact varieties of the pyroxenite and of some feldspar pyroxenite contain more acmite than the common pyroxenes.

4. The pyroxene from the hydrothermal alteration of the melilite is a diopside with little iron.

5 . The pyroxene in some limestone veins is much like the pyroxenes of the igneous rocks but has a larger ax'al angle.

6. The typical pyroxene of the hydrothermal contact metamorphism, that introduced into the surrounding granitic rocks by the Iron Hill stock, and that of most. of the other hydrothermal products are aegirites of rath er uniform composition.

Comparing the data for the three analyzed pyroxenes with the curves of Winchell, ${ }^{41}$ so far as such a comparison can be made on the simplified diagram, gives a reasonable check for the optical data except that the extinction angles measured on the Iron Hill pyroxen es are about $5^{\circ}$ high in specimen 2138 and $10^{\circ}$ high in specimen 1132 .

A consideration of the pyroxenes between diopside and acmite in view of the recent structural studies on the pyroxenes and a comparison of the availakle analyses of the series lead to the conclusions that the chief replacements have been $\mathrm{Mg}$ by $\mathrm{Fe}^{\prime \prime \prime}$ and $\mathrm{Ca}$ by Na. There have been replacements on a smaller scele of $\mathrm{Si}$ by $\mathrm{Al}, \mathrm{Mg}$ by $\mathrm{Fe}^{\prime \prime}$ and $\mathrm{Al}$, and $\mathrm{Ca}$ by $\mathrm{K}$. Mcst of these pyroxenes show only a small deficiency in Si. From experience with mineral groups in general we know that the replacement of $\mathrm{Mg}$ by $\mathrm{Fe}^{\prime \prime \prime}$ is likely to change the optical properties much more than an equal replacement of $\mathrm{Si}$ by $\mathrm{Al}, \mathrm{Mg}$ by $\mathrm{Fe}^{\prime \prime}$ or $\mathrm{Al}$, or $\mathrm{Ca}$ by $\mathrm{Na}$ or $\mathrm{K}$. It therefore seems reasonable to expect the most uniform and consistent variation curve by plotting the optical properties against $\mathrm{Fe}_{2} \mathrm{O}_{3}$, and such a plot is shown in figure 7 , in which the most reliable of the available data for these pyroxenes are plotted. Tris plot is not very different from one of acmite against diopside, as nearly all the pyroxenes contain sufficient or nearly sufficient $\mathrm{Na}_{2} \mathrm{O}$ to form acmite from all

${ }_{41}$ Winchell, A. N., Elements of optical mineralogy, pt. 2, p. 191, New York, Jchn Wiley \& Sons, 1927. 
the $\mathrm{Fe}_{2} \mathrm{O}_{3}$. A scale for acmite, assuming that all the $\mathrm{Fe}_{2} \mathrm{O}_{3}$ forms acmite, is also shown. Most of the curves are fairly regular except that for $\beta$. Further data might straighten the curve. The points fit the curves as well as could be expected, in view of the fact that only one of the variables in composition is used. The eurve may be considered to represent about the average groups show a considerable variation in their optical properties. The specimens selected to represent this variation were chosen for analysis. Each sample was carefully selected and the amphibole purified by. hand picking, heavy liquids, and an electromagnet. A microscopic examination showed less than 1 percent of impurities in most.of the samples; this was chiefly aegirite

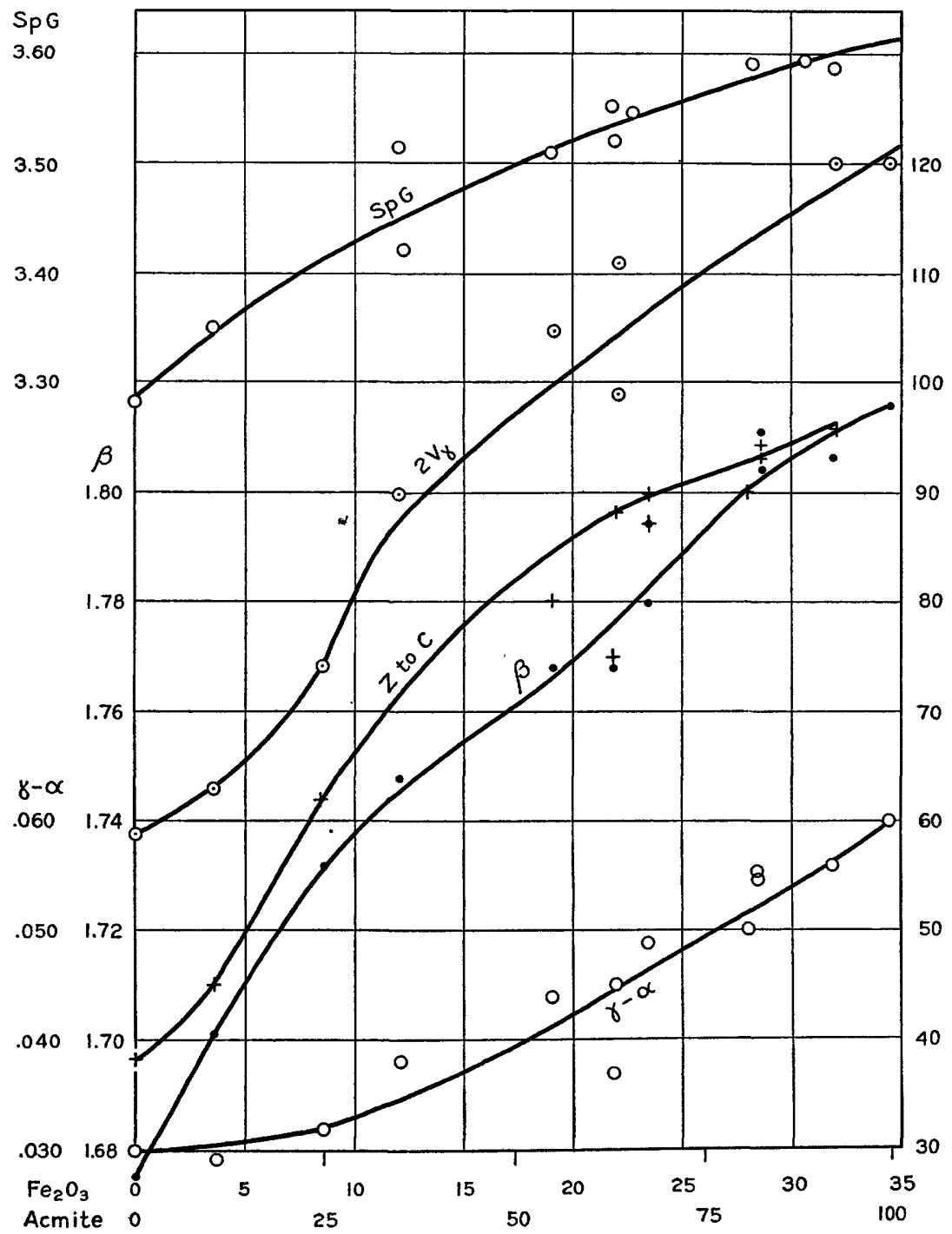

Figure 7.-Optical properties of the pyroxenes carrying acmite plotted against content of $\mathrm{Fe}_{2} \mathrm{O}_{3}$ (weight percent) and acmite (molecular percent).

of the variation of the optical properties of the pyroxenes with $\mathrm{Fe}_{2} \mathrm{O}_{3}$ content, and the other variables will modify the curve in detail.

\section{AMPHIBOLES}

Amphiboles are not present as primary magmatic minerals in any of the rocks of the Iron Hill stock, but they are among the most abundant and widespread of all the hydrothermal minerals in and about the stock. The field occurrence, the general appearance, and the microscopic study all showed that these amphiboles fall into two groups. The members of each of these with a composition near that of the amphiboles and would not affect the composition appreciably. In the few samples analyzed that had appreciable amounts of impurities, the impurities were carefully estimated with the microscope and a correction made. The analyses, atomic proportions calculated according to the unit cell as determined by X-ray studies, ${ }^{42}$ and optical properties are shown in table 20.

42 Warren, B. E., The structure of tremolite, $\mathrm{H}_{2} \mathrm{Ca}_{2} \mathrm{Mg}_{5}\left(\mathrm{SiO}_{3}\right)_{8}$ : Zeit shr. Kristallographie, Band 72, pp. 42-57, 1930; The crystal structure and chemical composition of the monoclinic amphiboles: Idem, Band 72, pp. 493-517, 1930. Berm $3 n$, Harry, and Larsen, E. S., Composition of the alkali amphiboles: Am. Mineralog'st, vol. 16, pp. 140-144, 1931. Kunitz, W., Die Isomorphieverhältnisse in der Horrblendegruppe: Neues Jahrb., Beilage-Band 60, Abt. A, pp. 171-250, 1930. 
ALKALIC ROCKS OF IRON HILL, GUNNISON COUNTY, COLO.

TABLE 20.-Analyses and optical properties of amphiboles from Iron Hill, Colo., Libby, Mont., and Trinity County, Calif.

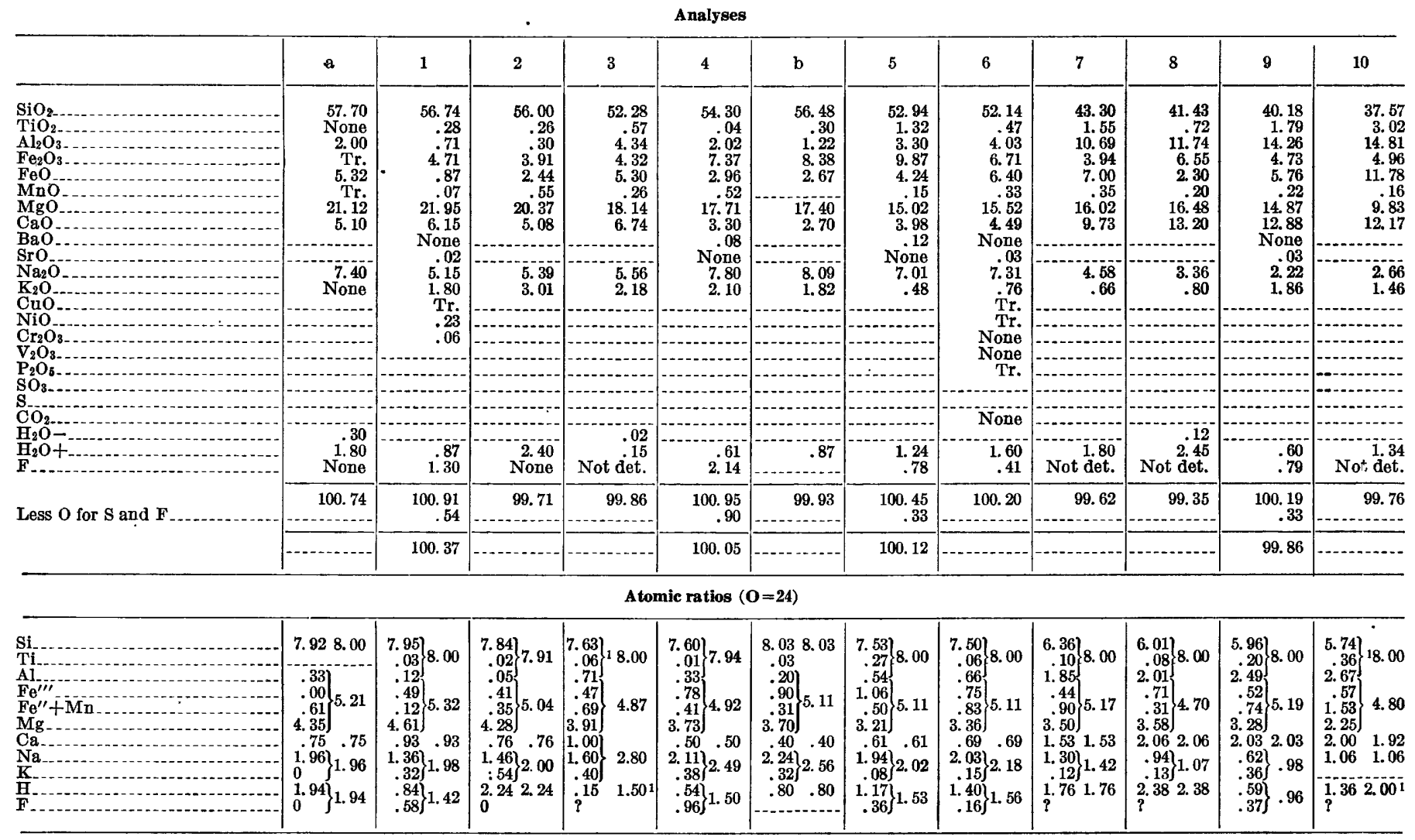

Theoretical end members

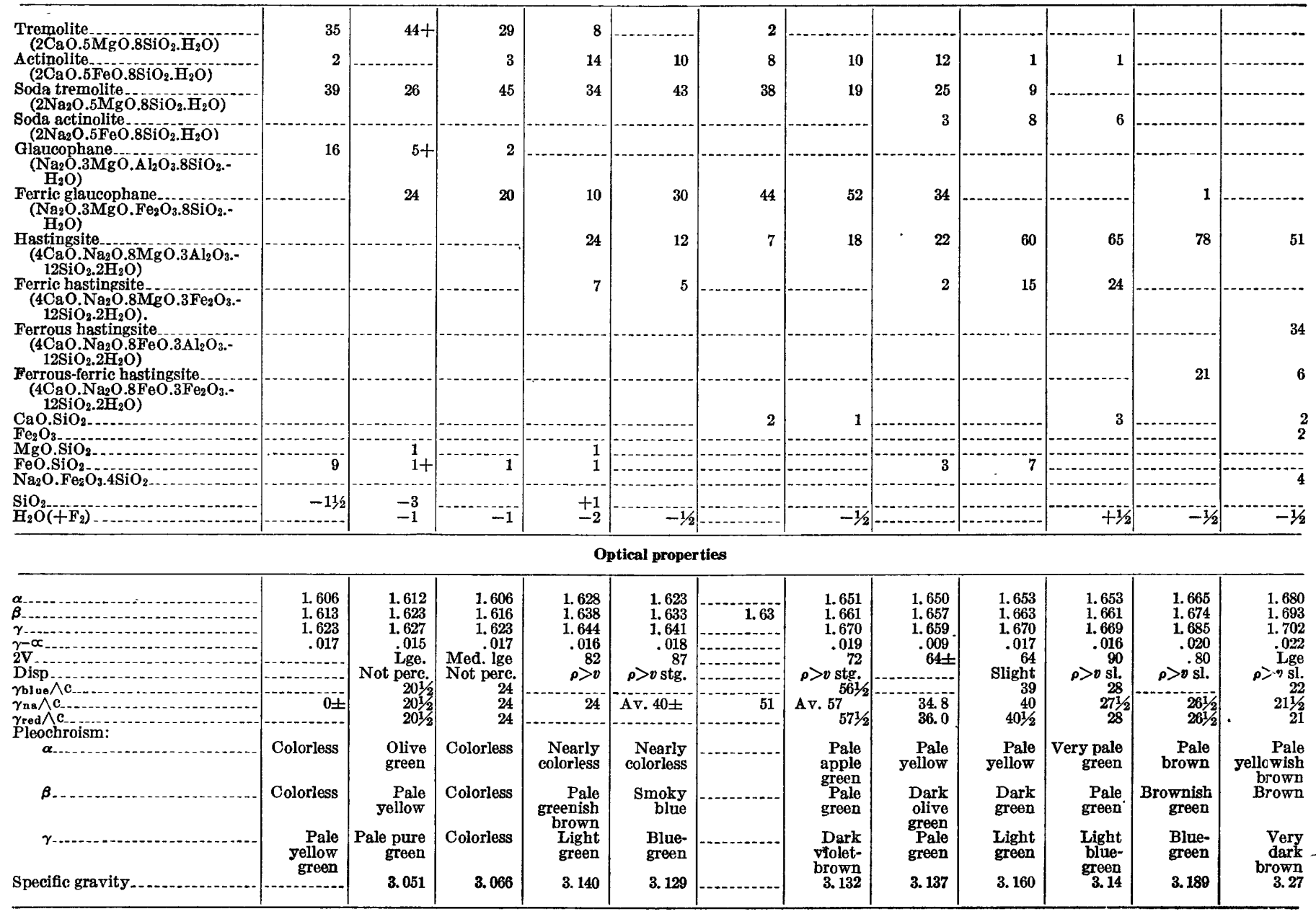

1 Assuming $\mathrm{F}+\mathrm{OH}=150$ (or 200). 
a. Soda anthophyllite, Trinity County, Calif. Analysis by J. D. Laudermilk.

1. (Libby 16948). Fibrous amphibole from Libby, Mont. Altered pyroxenite a few inches wide on both sides of a vein made up mostly of quartz but containing, next its wall, vanadiferous aegirite, strontianite, celestite, and sulfides. Some calcite associated with the amphibole. The optical properties of the amphibole vary a little. The properties given are about the average. Analysis by F. A. Gonyer.

2. (U-1994). South of lower Beaver Creek, west of gully A, and N. $86^{\circ}$ W. of knob $9800+$, which is north of Rudolph Hill, along fault between pre-Cambrian granite and syenite. Partly subparallel fibers of pale-green amphibole with some finely crystalline carbonate and large grains of apatite, partly granular calcite with prismatic crystals of nearly colorless amphibole. The material analyzed was taken from the coarse crystals in the calcite. Analysis by F. A. Gonyer. Zoned; optical properties, especially the extinction angle, vary somewhat.

3. (U-184e). Southwest bank of Sammons Gulch about 0.2 mile above the road. Veinlets of coarse amphibole in preCambrian schist. Coarse amphibole and aegirite in calcite.

4. (IH-39). Crest of ridge south of gully $A$ and about 500 feet east of the road. Limestone 50 feet from syenite. Mostly calcite with some prisms of amphibole and a little apatite, phlogopite, and aegirite. The amphoble is strongly zoned. There is little difference in the indices of refraction of the different zones, but the inner zone has an extinction angle of $55^{\circ}$, and the outer zone has one of $30^{\circ}$.

b. Asbestos from Camp Albion, Boulder County, Colo. Analyzed by E. E. Wahlstrom.

5. (IH-87). North side of south fork of Sammons Gulch, 50 feet from granite. A body of carbonate rock 1 foot across and a few feet wide in the pyroxenite may be a marble inclusion or a vein. Coarse amphibole prisms and aegirite embedded in coarsely crystalline calcite. Zoned. The indices of refraction of the zones do not vary much, but extinction angles range from $48^{\circ}$ to $60^{\circ}$; that of the outer zone is greater than that of the inner zone. Abnormal interference colors due to overlapping of layers with different extinction angles.

6. (U-1954). West side of ridge west of gully $\mathrm{C}$, halfway to crest. A seam in pyroxenite near idocrase diopside rock derived from uncompahgrite. Specimen is mostly granular calcite with 25 percent of green amphibole and some patches of talc (?) that have replaced olivine or pyroxene. The amphibole has irregular cores of colorless diopisde and clearly has replaced diopside. Some apatite and very little biotite.

7. (IH-43). Northeast slope of gully $A$ at an altitude of 8,70 feet, 50 feet below crest. A vein 1 foot wide cutting uncompahgrite (altered to idocrase and diposide). Most of the vein is granular calcite, but a narrow streak in the center is rich in coarse crystals of black amphibole. Analysis by W. H. Herdsman; optical data by E. S. Larsen and Marland Billings.

8. (U-1236). Pit on north side of gully about 1,500 feet south of Beaver Creek and 50 yards east of Cathedral Road. An altered uncompahgrite, now made up of idocrase, diopside, brown to colorless garnet, etc. Some streaks and patches contain calcite, amphibole, phlogopite, orthoclase, a little aegirite, and analcime.

9. (U-1993). A small cut below a larger cut east of gully $B$, northeast of point where forks are mapped, halfway up the ridge. From a prospect in pyroxenite with iron ore. Coarse amphibole replacing pyroxene. Distinctly zoned.

10. (IH-195). Cut in limestone inclusion in pyroxenite south of Sammons Gulch. Small vein of pyroxenite in limestone. May be a mixed rock. Contains pyroxene, amphibole replacing pyroxene, and some calcite and zeolites.

The table confirms the preliminary conclusion that the amphiboles fall into two groups. The minerals represented by analyses 1 to 6 are chiefly soda tremolite and glaucophane. Those of columns 8, 9, and 10 are magnesia hastingsites, and that of column 7 is a similar hastingsite with some riebeckite.

Soda-tremolite and glaucophane group.-Members of the soda tremolite-glaucophane group are the chief amphiboles of the area and-are the only amphiboles in the hydrothermally metamorphosed limestone, in the limestone deposits in the pre-Cambrian granitic rocks, in the sheeting planes and in veins in the granitic rocks surrounding the Iron Hill stock, and in the hydrothermal alteration products of the syenites. They are the chief amphiboles along the borders of the carbonate veins. Somewhat similar amphiboles, but richer in iron, are present as a replacement product of the pyroxene of the nepheline gabbro.

These amphiboles are nearly everywhere closely associated with aegirite, and they are the only ones so associated. The two minerals appear to have formed together, but in spite of this the aegirite $i$ rather uniform in composition, as indicated by its optical properties, whereas the amphibole varies greatly. Phlogopite is nearly everywhere associated with the amphibole and aegirite in the metamorphosed limestones.

Amphibole, aegirite, and phlogopite are the chief silicates in the replacement veins and less regular bodies that are abundant in the marble near the pyroxenite. Amphibole and aegirite are abundant near the borders of the many irregular hydrothermal bodies of crrbonate that occur in the pre-Cambrian rocks about the Iron Hill stock: Near the stock the closely spaced fractures in the older rocks carry thin seams of amphibole and aegirite, and in places these minerals have replaced the granite to give a rock like the fenite of Frögger. ${ }^{43}$ Nearly all the talus fragments of granite are coated with a thin layer of these minerals. In addition, some veins several inches across of aegirite and amphibole cut the schists near the mouth of Sammons Gulch and elsewhere. Many of the carbonate veins in the pyroxenite have amphibole and aegirite near their borders. These minerals have also been introduced into the soda syenite in many places along fractures which may be closely but irregularly spaced.

Similar amphiboles with associated aegirite $\mathrm{r}$ ave been observed by us in the fenite and other hydrothermal products from the Fen district of Norway. Similar amphiboles in fibrous or asbestos form are abundant in hydrothermal replacement veinlets in the pyroxenite at Libby, Mont., where they have replaced pryoxene and to a less extent biotite. In the Libby aria quartz veins cutting the pyroxenite contain sulfides, celestite, strontianite, and vanadiferous aegirite near their borders, and the adjoining pyroxenite is replaced for

43 Brógger, W. C., op. cit. The fenites from the Fen district in the Harvard collections are in part granites in which more or less amphibole and aegi ite have been hydrothermally introduced, and in part syenite in which some of these minerals have been introduced. 
several inches by fibrous amphibole. Elsewhere numerous replacement veinlets of this fibrous amphibole cut the pyroxenite; some of these have been prospected for asbestos. ${ }^{44}$

The amphibole described by Laudermilk and Woodford ${ }^{45}$ (analysis a, table 20) as a soda-rich anthophyllit, is probably a similar fibrous amphibole.

That from Camp Albion, Boulder County, Colo., described by Wahlstrom ${ }^{46}$ is also similar. It is in a

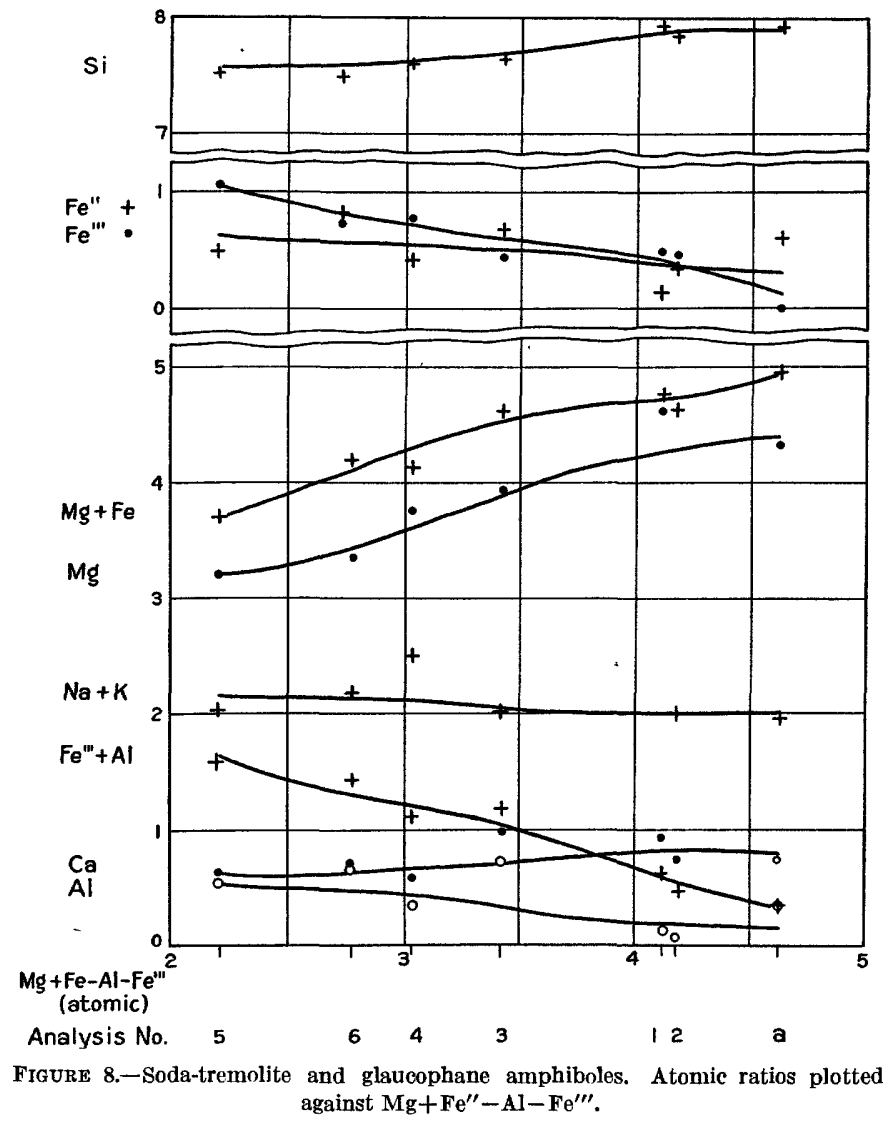

quartz vein associated with sulphides and aegirite.

These amphiboles range from pale to dark green. The crystals tend to be prismatic or even fibrous. For the most part they are microscopic, and the fibrous aggregates tend to have a silky luster. They vary from place to place in chemical composition and optical properties and are commonly more or less zoned.

The optical properties of many of these amphiboles have been determined, and six samples covering the range of optical properties have been analyzed. One of the analyzed specimens came from Libby, Mont. The analyses, atomic ratios calculated according to the unit cell as deduced from X-ray studies, and optical properties of these minerals are listed in table 20

44 Pardee, J. T., and Larsen, E. S., Deposits of vermiculite and other minerals in the Rainy Creek district, near Libby, Mont.: U. S. Geol. Survey Bull. 805, pp. 24-27, 1929. Larsen, E. S., and Pardee, J. T., The stock of alkaline rocks near Libby, Mont.: Jour. Geology, vol. 37, pp. 111-112, 1929.

45 Laudermilk, J. D., and Woodford, A. O., Soda-rich anthophyllite asbestos from Trinity County, Calif.: Am. Mineralogist, vol. 15, pp. 259-261, 1930.

46 Wahlstrom, E. E., An unusual occurrence of asbestos: Am. Mineralogist, vcl. 19 pp. 178-180, 1934. together with those of the "soda anthophyllite" from Trinity County, Calif. Five of these analyses were made by F. A. Gonyer with great care, using the method recommended by Hillebrand for silicates ccntaining fluorine. The analysis of specimen $\mathrm{IH}-1 \varepsilon 4 \mathrm{e}$ was made without this precaution and is not so reliable. This specimen probably contains much fluorine, as the $\mathrm{H}_{2} \mathrm{O}$ is low.

These amphiboles fit fairly well the general amphibole formula $(\mathrm{Ca}, \mathrm{Na})_{2} \mathrm{Na}_{0-1} \mathrm{Mg}(\mathrm{Mg}, \mathrm{Al})_{4}\left(\mathrm{Al}, \mathrm{Si}_{2}\right)_{2} \mathrm{Si}_{6} \mathrm{O}_{22}(\mathrm{O}, \mathrm{OH}$, $\mathrm{F})_{2}$, with $\mathrm{K}$ replacing $\mathrm{Na}$ in part and $\mathrm{Fe}^{\prime \prime}, \mathrm{Fe}^{\prime \prime \prime}, \mathrm{Mn}$, and Ti replacing more or less $\mathrm{Mg}$ and $\mathrm{Al}$. The $(\mathrm{Mg}, \mathrm{Al})$ group show more or less deviation from the formula. This may be partly due to the fact that much of the error in the calculation falls in this group. Even allowing for this, the $(\mathrm{Mg}, \mathrm{Al})$ group appears to be high in the first analysis, and the analysis appears to be entirely reliable. The high figure for this group may be due to the replacement of some $\mathrm{Na}$ and $\mathrm{Ca}$ by $\mathrm{Mn}$ and $\mathrm{Fe}^{\prime \prime}$, as their atomic radii are $.98,1.07, .92$, and .83 , respectively.

All seven amphiboles contain enough or nearly enough Si to fit a metasilicate formula. They range from low

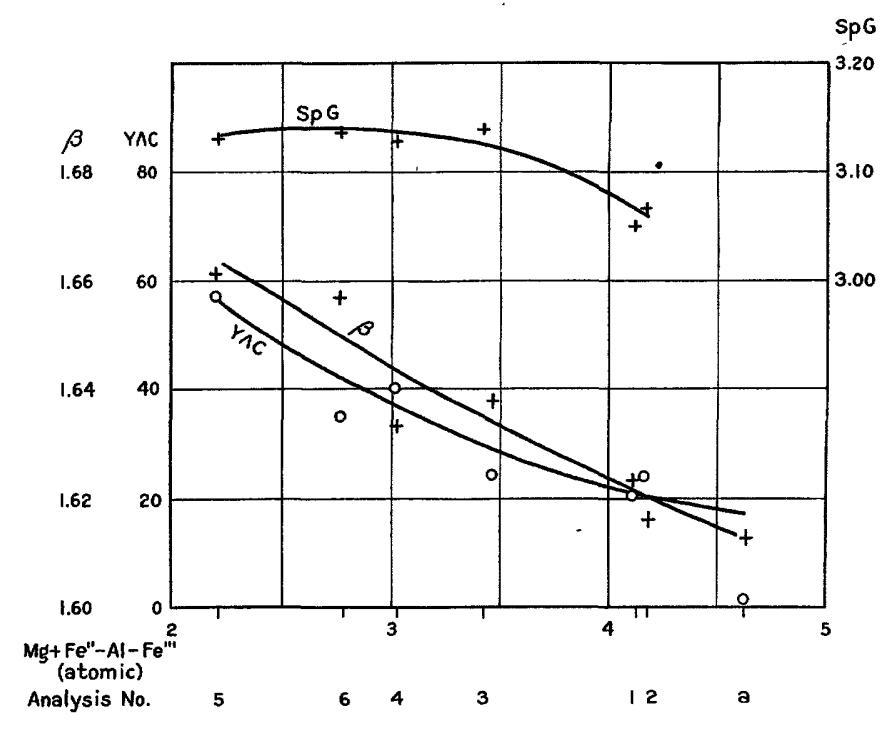

FIGURE 9. Soda-tremolite and glaucophane amphiboles. $\beta, \quad \mathrm{Y} \wedge \mathrm{c}$, and specific gravity plotted against $\mathrm{Mg}+\mathrm{Fe}^{\prime \prime}-\mathrm{AJ}-\mathrm{Fe}^{\prime \prime \prime}$.

to moderately low in $\mathrm{Al}$ and $\mathrm{Fe}^{\prime \prime}$, moderate in $\mathrm{Fe}^{\prime \prime \prime}$, high to rather high in $\mathrm{Mg}$, rather low in $\mathrm{Ca}$, high in total alkali, and high in $K$. All but two of them are ratter high in fluorine; those two are lacking in fluorine and have two units of $(\mathrm{OH})$, as is common in the amphiboles, whereas those containing fluorine have only about $1 \frac{1}{2}$ $(\mathrm{OH}, \mathrm{F})$.

In figure 8 are plotted the various atomic ratios for the different analyses against those for $\mathrm{Mg}+\mathrm{Fe}^{\prime \prime}-\mathrm{Al}$ $-\mathrm{Fe}^{\prime \prime \prime}$. The optical properties and specific gravities are plotted in figure 9.

Projecting these curves a short distance to the right we get an amphibole with the simple formula $\mathrm{Na}_{2} \mathrm{CaMg}_{5} \mathrm{Si}_{8} \mathrm{O}_{22}(\mathrm{OH}, \mathrm{F})_{2}$, or, to show only $1 \frac{1}{2}(\mathrm{OH}, \mathrm{F})$, 
it may be written $\mathrm{Na}_{11 / 2} \mathrm{Ca}_{11 / 2} \mathrm{Mg}_{5} \mathrm{Si}_{8} \mathrm{O}_{221 / 2}(\mathrm{OH}, \mathrm{F})_{11 / 2}$. In most of the minerals studied considerable $K$ has replaced $\mathrm{Na}$ and some $\mathrm{Fe}^{\prime \prime \prime}$ has replaced $\mathrm{Mg}$. The first fornula may be taken as that of soda tremolite; it would look much like tremolite but would have lower indices of refraction ( $\beta$ near 1.600), somewhat lower birefringence, and probably a larger extinction angle.

Projecting to the left for some distance gives the formula $\mathrm{Na}_{2} \mathrm{Ca}_{1 / 2} \mathrm{Mg}_{3} \mathrm{Al}_{2 / 2} \mathrm{Si}_{7 / 2} \mathrm{O}_{22}(\mathrm{OH}, \mathrm{F})_{2}$ with some $\mathrm{Fe}^{\prime \prime}$ and considerable $\mathrm{Fe}^{\prime \prime \prime}$ and $\mathrm{F}$. This might be considered as three-fourths glaucophane $\left(\mathrm{Na}_{2} \mathrm{Mg}_{3} \mathrm{Al}_{2} \mathrm{Si}_{8} \mathrm{O}_{22}(\mathrm{OH}, \mathrm{F})_{2}\right)$ and one-fourth hastingsite $\left(\mathrm{Ca}_{2} \mathrm{NaMg}_{4} \mathrm{Al}_{3} \mathrm{Si}_{6} \mathrm{O}_{22}(\mathrm{OH}, \mathrm{F})_{2}\right)$; or it is a glaucophane with some deficiency in silica and in which molecularly $\mathrm{Fe}^{\prime \prime}: \mathrm{Mg}^{\prime \prime}=1: 2$ and $\mathrm{Fe}^{\prime \prime \prime}: \mathrm{Al}^{\prime \prime \prime}=$ about $1: 1$.

Optically, the soda tremolite has a considerably lower index of refraction than tremolite with the same amount of iron; it also has lower birefringence and probably a larger extinction angle, but is otherwise similar and might easily be mistaken for tremolite. With increase in glaucophane and perhaps iron the indices of refraction, the depth of color, the extinction angle, and the dispersion increase. The extinction angle appears to be somewhat erratic, but there is a large increase from about $20^{\circ}$ for the members with low indices of refraction to over $60^{\circ}$ for those with high indices of refraction. Many of these amphiboles are strongly zoned, and the inner zone usually has lower indices of refraction, paler color, and smaller extinction angles than the outer. The glaucophane-rich varieties show abnormal interference colors, due to strong dispersion of the extinction angle. Some prisms show such colors as the result of overlapping of zones of different composition in the section.

The glaucophanes of this area are lower in $\mathrm{Al}$ and higher in $\mathrm{Mg}$ than most glaucophanes that have been analyzed. They have some similarity to anophorite. The extinction angles vary greatly in the different specimens and in different zones in the same crystal, although the other optical properties may not vary greatly. The available data indicate that a relatively small replacement of $\mathrm{Al}$ by $\mathrm{Fe}^{\prime \prime \prime}$ causes a large change in extinction angle; this is nearly equivalent to an increase in a molecule like riebeckite, which has a very large extinction angle $\left(\mathrm{Z} \wedge \mathrm{c}=83^{\circ}\right)$.

Hastingsite group. - Typical amphiboles belonging to the silica-poor hastingsite group are represented by columns 8,9 , and 10 , table 20 . Such amphiboles are much less abundant and widespread than the soda tremolite and glaucophane amphiboles described in the preceding section. They are found as hydrothermal replacement products of the pyroxenes in the pyroxenite, uncompahgrite, and ijolite and are chiefly in irregular veinlike bodies, rarely over a few inches wide. They occur in irregular grains, and the black cleavage surfaces are large, as much as 1 centimeter or more across, but the grains commonly contain remnants of unaltered pyroxene. Locally they are associated with pale-green secondary diopside, poor in iron. These amphiboles were formed after the alteration of the melilite of the uncompahgrite to idocrase and diopside, as the altered uncompahgrite nearly everywhere contains fresh pyroxene, which has beer replaced by hastingsite only along fractures that are later than the idocrase-diopside rock.

The amphibole represented by analysis 7 is a less typical hastingsite. It was found only in a single vein less than 1 meter across, composed of coarsely crystalline carbonate and amphibole. This amphibole is in irregular crystal grains as much as several millimeters across and makes up much of the vein in the central part but is nearly absent from the borders. The main part of the vein contains no amphibole.

The amphiboles that have replaced the pyroxene (columns 8 to 10) are hastingsite in which, molecularly Al greatly predominates over $\mathrm{Fe}^{\prime \prime \prime}$, and $\mathrm{Mg}$ ranges from greatly to slightly predominating over $\mathrm{Fe}^{\prime \prime \prime}$. They are very near the formula $\mathrm{NaCa}_{2} \mathrm{Mg}_{4} \mathrm{Al}_{3} \mathrm{Si}_{6} \mathrm{O}_{22}(\mathrm{OH}, \mathrm{F})_{2}$. Specimen 9 is greatly deficient in $(\mathrm{OH}, \mathrm{F})$. T. e relation between optical properties and chemical composition seems to be that the indices of refraction., depth of color, and probably the birefringence increase with the $\mathrm{Fe}^{\prime \prime}$, while the extinction angle decreases slightly. The axial angle is large for all.

The amphibole represented in column 7 can be considered to be made up of about three parts of hastingsite and one of soda tremolite. ' It is rather low in both $\mathrm{Fe}^{\prime \prime \prime}$ and $\mathrm{Fe}^{\prime \prime}$. Optically it differs from hastingsites low in iron (columns 8 and 9) in its smaller axial angle and larger extinction angle.

\section{WOLLASTONITE}

Wollastonite has been found only in small amount and at a single locality, just northwest of tha main forks of Beaver Creek, where it occurs in ijolite that has been contaminated by marble. It might be considered a reaction mineral between ijolite and marble.

\section{OLIVINES}

Olivine is a rare mineral in the area, although it is present in considerable amount in the nepheline gabbro and in the rare olivine varieties of the pyroxenite. Monticellite was found enclosed in cancrinite and associated with idocrase and melanite in a vein replaning the uncompahgrite in gully $\mathrm{C}, 250$ yards below its forks. ${ }^{47}$ It was also found in the marble inclusion in the pyroxenite between the forks of Sammons Gulch.'

The optical properties of characteristic olivines in the various occurrences are shown in table 21 . The olivine in the pyroxenite has only 10 to 21 percent of fayalite; that in the nepheline gabbro has about 42 percent.

\footnotetext{
47 Larsen, E. S., and Foshag, W. F., Cancrinite as a bigh-temperature hydrother-
} mal mineral from Colorado: Am. Mineralogist, vol. 11, p. 301, 1926. 
TABLE 21.-Optical properties of olivine group from Iron Hill, Colo.

\begin{tabular}{|c|c|c|c|c|c|}
\hline$\cdot$ & $\alpha$ & $\beta$ & $\boldsymbol{\gamma}$ & Optical character & Remarks \\
\hline $\begin{array}{l}\text { Olivine pyroxenite (U-1927) } \\
\text { Olivine pyroxenite (IH-325) } \\
\text { Nepheline gabbro (U-1172) } 10 \\
\text { Cancrinite vein (U-712) } \\
\text { Marble inclusion (IH-197a) }\end{array}$ & $\begin{array}{l}\text { 1. } 678 \\
\text { 1. } 654 \\
\text { 1. } 719 \\
\text { 1. } 653 \\
\text { 1. } 650\end{array}$ & $\begin{array}{r}1.70 \\
1.673 \\
1.741 \\
1.669 \\
-\end{array}$ & $\begin{array}{l}\text { 1. } 715 \\
\text { 1. } 693 \\
\text { 1. } 762 \\
\text { 1. } 674 \\
\text { 1. } 671\end{array}$ & $\left(\begin{array}{l}(+) 2 \mathrm{~V}=88^{\circ}-{ }_{-} \\
(+)\end{array}\right.$ & $\begin{array}{l}\text { Fayalite } 21 \text { percent. } \\
\text { Fayalite } 10 \text { percent. } \\
\text { Fayalite } 42 \text { percent. } \\
\text { Monticellite. } \\
\text { Do. }\end{array}$ \\
\hline
\end{tabular}

Rock analyzed.

\section{MICAS}

Muscovite.-Muscovite has not been found as a primary mineral nor is it an abundant or widespread hydrothermal mineral. In a few places the nepheline is altered to sericite, which is locally rather coarse. The feldspar in places contains some sericite.

Biotite and phlogopite.-Iron-magnesia micas are widespread minerals in the Iron Hill stock, where they make up about 13 percent of the igneous rocks. Thoy are among the chief minerals in hydrothermal contractmetamorphosed limestones and are less common in the carbonate veins and other hydrothermal products. They are especially abundant in the pyroxenite, and small bodies of rock are made up mostly of these micrs.

The optical properties of some of the typical micas from the various rocks are shown in table 22 .

TABLE 22.-Optical properties of iron-magnesia micas from Iron Hill

\begin{tabular}{|c|c|c|c|c|c|c|}
\hline Rock & $\alpha$ & $\boldsymbol{\beta}$ & $\gamma$ & $\begin{array}{c}\text { Birefring- } \\
\text { ence }\end{array}$ & Name & $\mathrm{FeO}+\mathrm{Fe}^{-\mathrm{O}_{2}}$ \\
\hline $\begin{array}{l}\text { Uncompahgrite } \\
\text { Olivine pyroxenite (IH-325) } \\
\text { Mica pyroxenite (U-1975) } \\
\text { Coarse pyroxenite (IH-101) } \\
\text { Ijolite (U-1132) } \\
\text { Nepheline syenite (U-1481) } \\
\text { Quartz gabbro (IH-321) } \\
\text { Metamorphosed marble: } \\
\quad \text { IH-2\{ } \begin{array}{l}\text { Intermediate zone } \\
\text { IH-20. }\end{array} \\
\text { IH-39. }\end{array}$ & $\begin{array}{l}\text { 1. } 562 \\
\text { 1. } 562 \\
\text { 1. } 565 \\
\text { 1. } 570 \\
\text { 1. } 582 \\
\text { 1. } 600 \\
\text { 1. } 576 \\
\text { 1. } 576 \\
\text { 1. } 581 \\
\text { 1. } 560\end{array}$ & $\begin{array}{r}1.600 \\
1.601 \\
1.604 \\
1.608 \\
1.633 \\
\hdashline\end{array}$ & $\begin{array}{l}\text { 1. } 600 \\
\text { 1. } 601 \\
\text { 1. } 604 \\
\text { 1. } 609 \\
\text { 1. } 633 \\
\text { 1. } 674 \\
\text { 1. } 68 \\
\text { 1. } 613 \\
\text { 1. } 614 \\
\text { 1. } 623 \\
\text { 1. } 590\end{array}$ & $\begin{array}{r}0.038 \\
.039 \\
.039 \\
.039 \\
.051 \\
.074 \\
.-. \\
.037 \\
.038 \\
.042 \\
.030\end{array}$ & 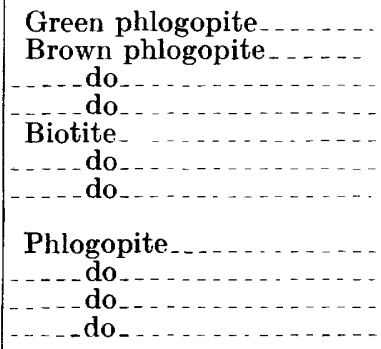 & $\begin{array}{r}\text { Little } \\
\text { Little } \\
\text { Little } \\
16 \\
38 \\
40 \\
8 \\
\mathrm{r}<\mathrm{v}\end{array}$ \\
\hline
\end{tabular}

The micas of any rock mass, such as the pyroxenite, are uniform even though the composition of the rock varies, but they show a progressive increase in iron from the earliest intrusives to the latest or from the less siliceous to the more siliceous. If we include melilite with the mafic minerals, they become richer in iron with decrease in mafic minerals, but the biotite of the quartz gabbro is an exception to this rule. As compared with the pyroxenes, the micas are more uniform in any one rock mass and they vary more regularly with the silica content of the rocks.

The micas of hydrothermal origin vary moderately in indices of refraction. They are in general strongly zoned, with a core that is pale brown, or less commonly green, and shows the usual pleochroism of biotite, and with one or two outer zones that may be darker or lighter than the core. Some of the outer zones have pleochroism the reverse of that common in the micas. The pleochroism of some of the typical zoned micas from the metamorphosed marble is shown in table 23 . In these zoned micas the indices of refraction are nearly the same in the different zones, and the axial angle, which is always very small, may be a little larger in the outer zones.
TABLE 23.-Pleochroism of zoned phlogopites from the metamorphosed marble

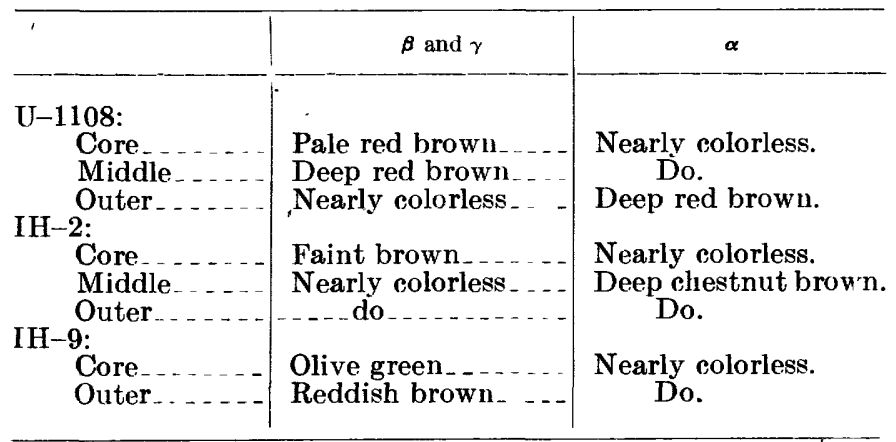

\section{APATITE}

The apatite of the area is all fluorapatite. Twenty measurements of the indices of refraction on apatite from the marble, veins, and various igneous rocks gave values of $\omega$ ranging from 1.633 to 1.642 .

\section{SPHENE}

Sphene is not a widespread mineral in the Iron Hill stock, but in some varieties of the pyroxenite it makes up as much as 30 percent of the rock. Its optical properties are normal, as shown by the following table: 


\begin{tabular}{|c|c|c|c|}
\hline & $\alpha$ & $\beta$ & $\gamma$ \\
\hline Sphene-rich pyroxenite (IH-104) _... & & 1. 908 & \\
\hline $\begin{array}{l}\text { Nepheline-sphene pyroxenite(U-2133, } \\
\text { analyzed) } \\
\text { Syenite (U-2106a) }\end{array}$ & 1.915 & $\begin{array}{l}1.922 \\
1.917\end{array}$ & 2. 020 \\
\hline
\end{tabular}

\section{PEROFSKITE}

Perofskite is present in the uncompahgrite, in nearly all varieties of the pyroxenite, and rarely in the ijolite. In some of the iron ore half or more is perofskite. Perofskite is estimated to constitute 6 percent of the Iron Hill stock. It is present in grains intergrown with magnetite, or as octahedral crystals as much as several millimeters across. In transmitted light it may appear nearly opaque without the accessory condenser, owing to its extremely high index of refraction, but with the condenser it is translucent in Saccardon umber (Ridgway's $17^{\prime \prime} \mathrm{k}$ ) and distinctly pleochroic, with the absorption $\mathrm{X}<\mathrm{Z}$. All the large crystals are birefracting and show lamellar twins in two sets at about $90^{\circ}$ that resemble albite and pericline twins in plagioclase. The index of refraction is 2.34 and the birefringence about 0.002. A spectroscopic test by G. A. Harcourt showed no Ce, Cb, or Ta.

\section{IDOCRASE}

Idocrase has been found only as a hydrothermal alteration product of the uncompahgrite and in a veinlet with cancrinite, monticellite, and melanite cutting the uncompahgrite. The optical properties of the mineral from the cancrinite vein and from the altered uncompahgrite are much alike: all are uniaxial negative and the indices of refraction vary \pm 0.002 from $\omega=1.737$, $\epsilon=1.733$. The indices of refraction are considerably higher than those previously reported for idocrase, and the mineral may have titanium or iron. Spectroscopic tests on the mineral from Iron Hill by E. K. Gedney showed some BeO.

\section{MELANITE}

The garnet of the area is mostly black in mass and red brown in thin section. Its index of refraction ranges from less than 1.85 to 1.98 . It is titanium-rich and a melanite. An approximate analysis of the melanite from the ijolite has been made by $W$. T. Schaller and is given below, together with an analysis of a similar garnet from a sinilar rock near Turja, Russia. ${ }^{48}$

\footnotetext{
48 Kranck, E. H., op. cit. (Fennia 51, no. 5), p. 23.
}

TABLE 25.-Analyses of melanite

\begin{tabular}{|c|c|c|}
\hline & Colorado & Turja \\
\hline 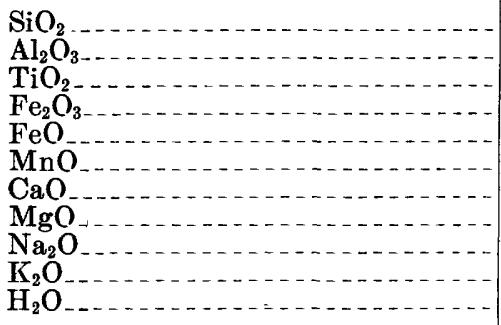 & 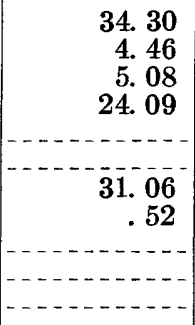 & $\begin{array}{r}\text { 33. } 10 \\
\text { 3. } 36 \\
6.34 \\
21.37 \\
1.10 \\
.28 \\
32.36 \\
1.09 \\
\text { None } \\
.22 \\
.20\end{array}$ \\
\hline$n_{-\ldots} \ldots \ldots$ & $\begin{array}{c}99.51 \\
1.907\end{array}$ & $\begin{array}{c}99.42 \\
\text { 1. } 895-1.900\end{array}$ \\
\hline
\end{tabular}

Much of the melanite of the ijolite has an index of refraction between 1.97 and 1.98 . In a specimen of the uncompahgrite the main part of the garnet is darkcolored and has an index of refraction of 1.95; this grades to a light-colored border that has an index of refraction as low as 1.85. Some of the late hydrothermal garnet in the uncompahgrite is light-colored, has a much lower index of refraction, and is near grossularite.

The melanite is present in variable amounts in most of the igneous rocks of the area and is in part a late magmatic and deuteric mineral, but it continued to crystallize into the hydrothermal stage. - It is present in especially large amount in the ijolite.

\section{CHLORITES, SERPENTINE, AND VERMICULITES}

Chlorites are not abundant in the area, but they are present locally as late hydrothermal minerals in veins and in the altered part of the silicates. Sempentine was found chiefly as an alteration product of olivine.

The phlogopite has undergone more or less alteration and in places approaches the vermiculite jefferisite, but no such large-scale development of vermiculite was found as is present at Libby, Mont. ${ }^{49}$ Mucl of the mica at Iron Hill is relatively fresh.

\section{CANCRINITE AND SULFATIC CANCRINITE}

Cancrinite is a very common mineral in the Iron Hill area, chiefly as an alteration product of nemheline, rarely in veinlets, and in small part as a prinary (?) mineral in the igneous rocks. Most of the cencrinite is of the ordinary variety and in the usual granular aggregates. A single veinlet cutting uncompahgrite was made up of coarsely crystalline cancrinite in cleavage pieces as much as 10 centimeters across enclosing

49 Pardee, J. T., and Larsen, E. S., Deposits of vermiculite and other minerals in the Rainy Creek district, near Libby, Mont.: U. S. Geol. Survey Bull. 805, pp. 1728,1928 . 
monticellite, melanite, and other minerals. In parts of the veinlet idocrase occupies the position of the cancrinite as host for the monticellite. Pale-green phlogopite, calcite, and melanite, together with chlorite and zeolites, make up the borders of the veinlet. The monticellite, idocrase and melanite are most closely associated with the cancrinite. An analysis of this cancrinite by W. F. Foshag is shown in column 1, table $26 .^{50}$

TABLE 26.-Analyses and properties of cancrinite

\begin{tabular}{|c|c|c|}
\hline & $\begin{array}{c}1 \\
\text { Cancrinite }\end{array}$ & $\begin{array}{c}2 \\
\text { Sulfatic } \\
\text { cancrinite }\end{array}$ \\
\hline 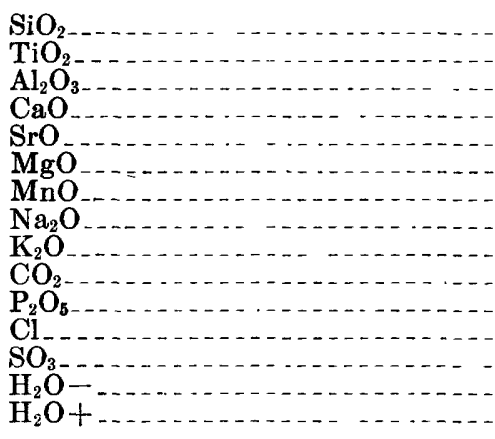 & $\begin{array}{r}\text { 33. } 64 \\
.07 \\
29.82 \\
8.64 \\
39 \\
\text { Tr. } \\
\text { 15. } 41 \\
.50 \\
6.79 \\
\text { None } \\
\text { Tr. } \\
.03 \\
\text { 4. } 61\end{array}$ & 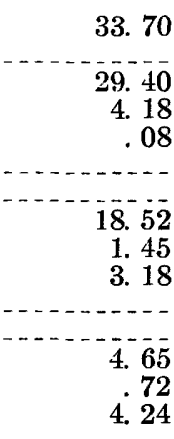 \\
\hline & 99. 90 & 100. 12 \\
\hline $\begin{array}{l}\text { Specific gravity } \\
\omega\end{array}$ & $\begin{array}{r}2.51 \\
1.524 \\
1.501\end{array}$ & $\begin{array}{l}\text { 2. } 443 \\
\text { 1. } 509 \\
\text { 1. } 500\end{array}$ \\
\hline
\end{tabular}

Sulfatic cancrinite was found only on the hill surrounded by the 8,500 -foot contour between gullies $\mathrm{A}$ and B south of Beaver Creek. It is probably derived from nepheline or melilite. An analysis of it is given in column 2 of table 26.51

\section{NATROLITE}

A fibrous zeolite, answering the descriptions of hydronephelite, is the most common alteration product of nepheline. In most places the mineral is very finely fibrous and mixed with other minerals, but some veinlike bodies on the west slope near the top of the hill surrounded by the 8,500 -foot contour, about 0.6 mile southeast of the point where the road up Cebolla Creek crosses Beaver Creek, were made up of more coarsely crystalline and purer material.

This material is white and consists of coarse fibers which are rudely parallel or matted and are nearly pure, though clouded. There is some associated pyrite.

\footnotetext{
s0 Larsen, E. S., and Foshag, W. F., Cancrinite as a high-temperature hydrothermal mineral from Colorado: Am. Mineralogist, vol. 11, pp. 300-303, 1926.

s1 Larsen, E. S., and Steiger, George, Sulphatic cavcrinite from Colorado: Am. Jour. Sci., 4th ser., vol. 43, pp. 332-334, 1916.
}

The mineral appears to have a perfect cleavage or fracture parallel to the length of the fibers. It has a hardness of $4 \frac{1}{2}$. Its optical properties are given in column 1 of table 27 , those of natrolite in column 2 , and those commonly assigned to hydronephelite in column 3.

TABLE 27.-Optical properties.of natrolite

\begin{tabular}{|c|c|c|c|}
\hline & 1 & 2 & 3 \\
\hline & $1.481 \pm 0.001 \ldots$ & $\left\{\begin{array}{l}1.480 \\
1.482\end{array}\right.$ & 1. 490 \\
\hline $2 \mathrm{~V}$ & $\begin{array}{l}1.492 \pm 0.001 \\
\text { Near } 0^{\circ} \ldots \\
(+)\end{array}$ & $\begin{array}{r}\text { 1. } 493 \\
63^{\circ} \\
(+)\end{array}$ & $\begin{array}{c}1.502 \\
\text { Near } 0^{\circ} \\
(+)\end{array}$ \\
\hline
\end{tabular}

An analysis of the material, estimated to be at least 99 percent natrolite, was made by S. Parker, of Zurich, and is given in the first column of table 28.

TABLE 28.- Analysis and ratios of natrolite from Iron Hill, Colo.

\begin{tabular}{|c|c|c|c|}
\hline Analysis & & Molecular ratios & $\begin{array}{c}\text { Theoretical rat- } \\
\text { rolite } \\
\left(\mathrm{Na}_{2} \mathrm{O}_{4} \mathrm{Al}_{2} \mathrm{O}_{3}\right. \\
\left.3 \mathrm{SiO}_{2} .2 \mathrm{H}_{2} \mathrm{O}\right)\end{array}$ \\
\hline $\begin{array}{l}\mathrm{SiO} \mathrm{O}_{2} \\
\mathrm{Al}_{2} \mathrm{O}_{3} \\
\mathrm{Fe}_{2} \mathrm{O}_{3} \\
\mathrm{MnO}^{\mathrm{MgO}} \\
\mathrm{CaO} \\
\mathrm{Na}_{2} \\
\mathrm{~K}_{2} \mathrm{O} \\
\mathrm{H}_{2} \mathrm{O} \\
\mathrm{H}_{2} \mathrm{O} \\
\mathrm{CO}_{2} \\
\mathrm{SO}_{3} \\
\mathrm{Cl}\end{array}$ & $\begin{array}{r}45.51 \\
27.47 \\
.36 \\
\mathrm{Tr} . \\
.21 \\
1.23 \\
14.24 \\
2.01 \\
9.12 \\
.05 \\
.00 \\
.22 \\
.00 \\
100.42\end{array}$ & 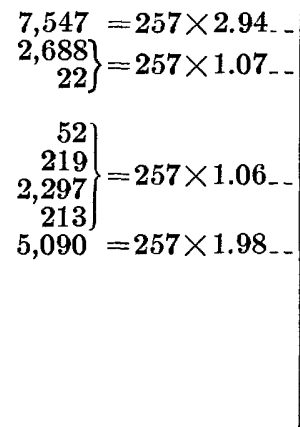 & $\begin{array}{l}\text { 47. } 5 \\
\text { 26. } 11\end{array}$ \\
\hline
\end{tabular}

These data indicate that at least some of the material called hydronephelite is natrolite and confirm the conclusion of Thugutt ${ }^{52}$ that hydronephelite is not a distinct species but is a fibrous variety of natrolite w:th some admixture of other minerals. The apparent uniaxial character is an aggregate effect from the subparallel fibers.

\section{ANALCIME}

Analcime is one of the most abundant minerals formed from the alteration of nepheline and males nearly half of some parts of the ijohte. A considerable body of such rock was found on the ridge betwe en North Beaver Creek and gully $\mathrm{N}$ just above the alluvium, and a specimen from this locality was analyzed (table 9, column 5). The analcime of this rock has an index of refraction of 1.493, somewhat higher than that

${ }^{2}$ Thugutt, St. J., Ein mikrochemischer Beweis der zusammengesetzen Natur des Hydronephelits nebst Bemerkungen über die Abstammung der Spreusteine: Noues Jahrb., Beilage Band I, pp. 25-36, 1910. 
commonly given for analcime. It is so intimately mixed with calcite and other secondary minerals that it could not be separated for analysis. The simplest assumption to account for the high index of refraction of this analcinie is that some of the $\mathrm{Na}$ has been replaced by $\mathrm{Ca}$, but an analcime with a similar high index of refraction from the Highwood Mountains, Mont., has been analyzed and contains about 4.48 percent of $K_{2} \mathrm{O}$ replacing the $\mathrm{Na}_{2} \mathrm{O}$.

\section{JUANITE AND CEBOLITTE}

After the melilite had been partly replaced by idocrase and diopside, four more successive waves of alteration replaced more or less of the remaining melilite. ${ }^{53}$ The first of these alterations changed it to the mineral juanite. The juanite occur in fibrous aggregates with parallel extinction and positive elongation. It is probably optically positive; $2 \mathrm{~V}=50^{\circ}($ ?). The average of two closely agreeing analyses by F. A. Gonyer of the mineral from different localities is given in table 29.

An undetermined fibrous mineral followed the juanite, and then cebollite ${ }^{54}$ was formed in veinlets. An analysis of cebollite by W. T. Schaller is given in table 29 .

\footnotetext{
${ }^{53}$ Larsen, E. S., and Goranson, E. A., The deuteric and later alteration of the uncompahgrite of Iron Hill, Colo.: Am. Mineralogist, vol. 17, pp. 343-356, 1932.

${ }^{54}$ Larsen, E. S., and Schaller, W. T., Cebollite, a new mineral: Washington Acad Sci. Jour., vol. 4, pp. 480-482, 1914,
}

TABLE 29.-Analyses of juanite and cebollite

\begin{tabular}{|c|c|c|}
\hline & Juanite & Cebollite \\
\hline 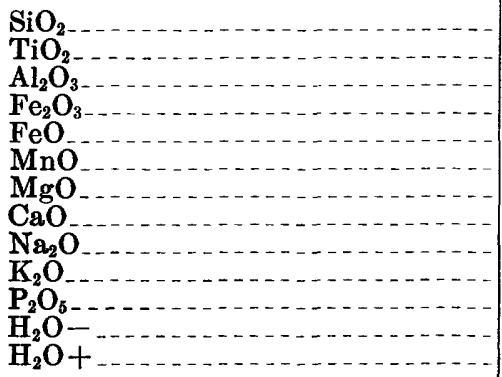 & $\begin{array}{r}42.30 \\
\text { None } \\
5.41 \\
2.68 \\
.56 \\
.10 \\
9.07 \\
34.84 \\
.95 \\
.09 \\
.04 \\
.18 \\
4.06\end{array}$ & $\begin{array}{r}33.02 \\
14.02 \\
3.43 \\
.21 \\
4.69 \\
\text { 35. } 72 \\
2.57 \\
\text { Tr. } \\
\text { None } \\
6.26\end{array}$ \\
\hline & 100. 28 & 99. 92 \\
\hline $\begin{array}{l}\text { Specific gravity } \\
\boldsymbol{\alpha}_{-} \\
\boldsymbol{\beta}_{-}\end{array}$ & $\begin{array}{r}3.01 \\
1.640 \\
1.647\end{array}$ & $\begin{array}{r}2.96 \\
1.592 \\
1.597 \\
1.630\end{array}$ \\
\hline
\end{tabular}

\section{MINOR CONSTITUENTS}

By Esper S. Larsen and George Steiger

The chief minor constituents, $\mathrm{TiO}_{2}, \mathrm{P}_{2} \mathrm{O}_{5}, \mathrm{MnO}, \mathrm{BaO}$, and $\mathrm{SrO}$, have been determined on nearly all the analyzed rocks from Iron $\mathrm{Hill}$, and $\mathrm{ZrO}_{2}, \mathrm{NiO}, \mathrm{Cr}_{2} \mathrm{O}_{3}$, $\mathrm{V}_{2} \mathrm{O}_{3}, \mathrm{Cl}$, and $\mathbf{F}$ on many. Similar determinations have been made on many of the minerals, and estumates have been made for the other minerals by using rocks in which the minerals were the chief constituent. These data are assembled in table 30.

TABLE 30.-Minor constituents in rocks and minerals of Iron Hill and other areas

\begin{tabular}{|c|c|c|c|c|c|c|c|c|c|c|c|c|}
\hline & $\mathrm{TiO}_{2}$ & $\mathbf{P}_{2} \mathrm{O}_{\mathbf{r}}$ & Mno & $\mathrm{BaO}$ & sro & $\mathrm{ZrO}_{2}$ & $\mathrm{NiO}$ & $\mathrm{Cr}_{2} \mathrm{O}_{3}$ & $\mathrm{~V}_{2} \mathrm{O}_{3}$ & $\mathrm{Cl}$ & $\mathbf{F}$ & Source \\
\hline Uncompahgrite: & & & & & & & & & & & & \multirow{9}{*}{$\begin{array}{r}\text { Steiger. } \\
\text { Do. } \\
\text { Do. } \\
\text { Do. }\end{array}$} \\
\hline Coarse $(\mathrm{U}-718)$ & 1.71 & $\begin{array}{r}0.09 \\
.83\end{array}$ & $\begin{array}{l}0.20 \\
.16 \\
.2\end{array}$ & $\begin{array}{l}0.05 \\
.05\end{array}$ & $\begin{array}{r}0.57 \\
.48\end{array}$ & $\begin{array}{r}0.02 \\
.02\end{array}$ & & & & & & \\
\hline $\begin{array}{l}\text { Fine (U-2015) } \\
\text { Idocrase-diopside rock (U-2197) }\end{array}$ & $\begin{array}{l}1.98 \\
1.00\end{array}$ & .88 & .11 & ........ & .21 & $\ldots$ & & & & & $\cdots$ & \\
\hline $\begin{array}{l}\text { Pyroxenite: } \\
\text { A verage }\end{array}$ & \multirow{6}{*}{\begin{tabular}{|c|}
7.4 \\
4.76 \\
9.02 \\
8.79 \\
6.60 \\
1.70 \\
24.74 \\
35.05
\end{tabular}} & \multirow{6}{*}{$\begin{array}{l}1.3 \\
.45 \\
\text { None } \\
6.35 \\
.03 \\
1.49 \\
5.58 \\
.58\end{array}$} & \multirow{6}{*}{$\begin{array}{l}.14 \\
.16 \\
.06 \\
.15 \\
.06 \\
.36 \\
.26 \\
.24\end{array}$} & \multirow{6}{*}{$\begin{array}{l}.13 \\
.03 \\
.08 \\
.48 \\
.04 \\
.05 \\
.05\end{array}$} & \multirow{2}{*}{\multicolumn{2}{|c|}{ Tr. }} & \multirow[b]{2}{*}{ Tr. } & \multirow[b]{2}{*}{ Tr. } & \multirow{2}{*}{$\begin{array}{r}0.04 \\
.04\end{array}$} & \multirow[b]{2}{*}{ Tr. } & \multirow[b]{2}{*}{0.1} & \\
\hline $\begin{array}{l}\text { Average } \\
\text { Fine }(\mathrm{U}-1199)\end{array}$ & & & & & & & & & & & & \\
\hline Coarse (IH-101) & & & & & .06 & - & & & & & & \\
\hline $\begin{array}{l}\text { Biotite rock (U-1975) } \\
\text { Olivine pyroxenite (IH-325) }\end{array}$ & & & & & .17 & ... & 0.02 & 0.01 & .03 & 0.04 & .07 & \\
\hline Shonkinite (U-2138) & & & & & None & & & & & & .25 & \\
\hline $\begin{array}{l}\text { Biotite-magnetite-perofkite } \\
\text { Magnetite-perofskite ore (U-2108) }\end{array}$ & & & & & $\begin{array}{l}.12 \\
.06\end{array}$ & .01 & .05 & None & .06 & None & .13 & \\
\hline $\begin{array}{l}\text { Ijolite: } \\
\text { A verage }\end{array}$ & & & & & & & & & 05 & -1 & & Do. \\
\hline $\begin{array}{l}\text { Aphene (U-2133) } \\
\text { Pyroxene fine (U-1877) }\end{array}$ & $\begin{array}{l}5.35 \\
.32\end{array}$ & $\begin{array}{l}1.2 \\
3.11 \\
1.45\end{array}$ & $\begin{array}{l}.18 \\
.18\end{array}$ & None & .13 & None & None & None & & & & $\begin{array}{l}\text { Do. } \\
\text { Do. }\end{array}$ \\
\hline $\begin{array}{l}\text { Pyroxene-melanite (U-1132) } \\
\text { Melanite (U-2011) }\end{array}$ & 2.45 & 1.78 & .16 & None & None & .02 & & & & & & Do. \\
\hline $\begin{array}{l}\text { Melanite }(\mathrm{U}-2011) \\
\text { Analcime (U-1265) }\end{array}$ & $\begin{array}{l}4.41 \\
4.86\end{array}$ & .08 & .19 & None & None & .05 & -...-.- & None & .05 & $\cdots$ & $\cdots$ & Do. \\
\hline Soda syenite $(\mathrm{U}-1206 \mathrm{a})=$ & $\begin{array}{l}4.80 \\
.20\end{array}$ & $\begin{array}{l}.04 \\
.04\end{array}$ & .13 & .03 & .03 & .03 & None & None & None & $\ldots . .$. & Tr. & Do. \\
\hline Nepheline syenite (U-1481). & .40 & .03 & .07 & .16 & .12 & .02 & & & & - & & Do. \\
\hline $\begin{array}{l}\text { Nepheline gabbro (U-1172) } \\
\text { Quartz gabbro (IH-301) }\end{array}$ & $\begin{array}{l}1.12 \\
1.54\end{array}$ & .25 & .11 & 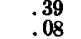 & $: 04$ & & . & & ...... & . & .14 & $\begin{array}{l}\text { Do. } \\
\text { Do. }\end{array}$ \\
\hline $\begin{array}{l}\text { Mineras: } \\
\text { Orthoclase and albite }\end{array}$ & & & & Low & Low & & & & & & & Fstimsted \\
\hline Plagioclase: & & & & & & & & & & & & Estimated. \\
\hline $\begin{array}{l}\text { Nepheline gabbro.. } \\
\text { Onpartz gabbro }\end{array}$ & & &.- & High? & High? & & & & & & & Do. \\
\hline $\begin{array}{l}\text { Quärtz gabb̆ro.... } \\
\text { Nepheline }\end{array}$ & & & & Low & Low & & & & & & & Do. \\
\hline Melilite... & & & .16 & .03 & .82 & & $\cdots$ & & & & & Gonyer. \\
\hline Pyroxene: & & & & & & & & & & & & \\
\hline $\begin{array}{l}\text { Augite (IH-129) } \\
\text { Acmite diopside (Ũ-2138) }\end{array}$ & .70 & $\cdots$ & .28 & $\begin{array}{l}.00 \\
.22\end{array}$ & .07 & & & & .04 & & & Do. \\
\hline Aegirite & .82 & & .38 & .05 & None & & & & & & & Do. \\
\hline Melanite.... & 5.0土 & & Little & $\begin{array}{l}\text { None? } \\
\text { None }\end{array}$ & $\begin{array}{c}\text { None? } \\
\text { None }\end{array}$ & & & None & .01 & & & TiO 2 Schaller, \\
\hline Biotite_. & Low? & & .14 & .92 & .04 & $\ldots$ & .02 & .01 & .04 & .03 & None & Steiger. \\
\hline & High & & $\begin{array}{l}\text { None } \\
\text { Low }\end{array}$ & None & Mod.? & None & None & None & & & & $\begin{array}{l}\text { Do. } \\
\text { Estimated. }\end{array}$ \\
\hline $\begin{array}{l}\text { Magnetite } \\
\text { Perofskite }\end{array}$ & High & & .24 & None & None? & & .05 & None & .06 & & & Do. \\
\hline
\end{tabular}


ALKALIC ROCKS OF IRON HILL, GUNNISON COUNTY, COLO.

TABLE 30.-Minor constituents in rocks and minerals of Iron Hill and other areas-Continued

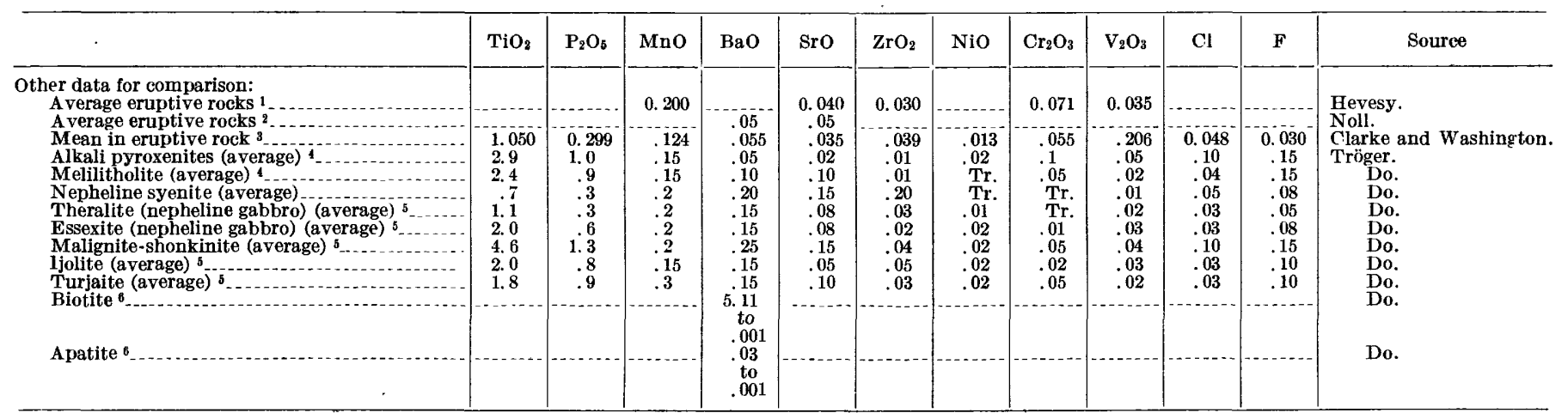

' Hevesy, v. G., and Würstlin, K., Ủber die Häufigkeit des Strontiums; Zeitschr. anorg. u. allgem. Chemie, Band 216, pp. 312-314, 1934. Hevesy, v. G., Merkal, A. and Würstlin, K., Die Häufigkeit des Chroms und Mangans: ldem, Band 219, pp. 192-196, 1934. Cr is mostly in ultrabasic rocks. Mn shows no marked preference. Hevesy, v. G., and Würstlin, K., Die Häufigkeit des Zirkonium: ldem, Band 216 pp. 304-311, 1934. Hevesy, v. G., Alexander, E., and Würstlin, K., Die Hăufigke der Element 1930 .

2 Noll, W. Geochemie des Strontiums: Chemie der Erde, Band 8, pp. 507-600, 1934 $\mathrm{Sr}$ prefers alkaline rocks; $\mathrm{Ba}$ is greater in granitic rocks, von Englehardt, Die $\mathrm{Geo-}$ chemie des Bariums: 1dem, Band 10, p. 221, 1936. Found 0.048 percent of $\mathrm{BaO}$ for the average eruptive rock.

A comparison of the Iron Hill rocks with the average for the rock families to which each belongs as given by Tröger ${ }^{55}$ brings out the following results.

1. $\mathrm{TiO}_{2}$ is about $2 \frac{1}{2}$ times as high in the pyroxenite as in the average alkalie pyroxenite, it is very low in the rocks with alkalic feldspar, and is about average for the other rocks. It is high in the province as a whole.

2. $\mathrm{P}_{2} \mathrm{O}_{5}$ is a little high in the pyroxenite and ijolite, very low in the rocks with alkalic feldspar, and slightly low in the other rocks. It is about average or a little high in the province as a whole.

3. $\mathrm{MnO}$ is about average in most of the Iron Hill rocks but somewhat low in the nepheline gabbro and nepheline syenite.

4. $\mathrm{BaO}$ is about $2 \frac{1}{2}$ times as high as in the average of rocks of the corresponding families for the pyroxenite and nepheline gabbro, $1 \frac{1}{2}$ times as high for the quartz gabbro, about normal for the nepheline syenite, and very low in the uncompahgrite, ijolite, and syenite. It is very high im the province.

5. $\mathrm{SrO}$ is four times as high in the pyroxenite, nepheline gabbro, and uncompahgrite as in the average of similar rocks, twice as high in the quartz gabbro, about equal in the rocks with alkalic feldspar, and very low in the ijolites. It is very high in the province as a whole, and $\frac{\mathrm{SrO}}{\mathrm{BaO}}$ is higher than is common.

6. $\mathrm{ZrO}, \mathrm{NiO}$, and $\mathrm{Cr}_{2} \mathrm{O}_{3}$ are in general low.

7. $\mathrm{V}_{2} \mathrm{O}_{3}$ appears to be near the average or low.

8. $\mathrm{Cl}$ is low where determined.

9. $\mathrm{F}$ is low according to the analyses, but it is probably near the average as indicated by the abundance of fluorapatite.

In general the outstanding features of the Iron Hill province appear to be the high $\mathrm{TiO}_{2}, \mathrm{BaO}$, and $\mathrm{SrO}$; the low $\mathrm{ZrO}$; the tendency for the rocks with much

5s Tröger, E. Chemie der Erde, Band 9, pp. 305-307.
3 Clarke, F. W., and Washington, H. S., U. S. Geol. Survey Prof. Paper 127, F. 16 1924. SrO and NiO corrected by Tröger, E., Der Gehalt an Selteneren Elemèten bei Eruptivgesteinen: Chemie der Erde, Band 9, p. 289, 1935

Tröger, E., op. cit., p. 307.

' von Engelhardt, op. cit., pp. 212.218. alkalic feldspar to be unusually low in the minor constituents; and the very low $\mathrm{BaO}$ and $\mathrm{SrO}$ in the ijolite.

Titanium.-Titanium oxide is very high in the Iron Hill province as a whole. It is unusually high in the pyroxenite, averaging 7.4 percent and reaching over 35 percent in some of the perofskite iron ore bodies. It is high in the ijolite and moderate in the uncompahgrite and other rocks. As compared with its content in similar rocks from other areas, it is over seven times as high as in the average diallagite of Daly, which has only 0.97 percent $\mathrm{TiO}_{2} ; 2 \frac{1}{2}$ times as high as in the average alkalic pyroxenite of Tröger, nearly twice as high as in the similar jacupirangites from Jacupiranga, Brazil, and Magnet Cove, Ark. (4.32 and 4.53 percent, respectively), and seven tines as high as in the similar pyroxenite from Libby, Mont.

In the ijolite, the $\mathrm{TiO}_{2}$ varies greatly but the extremes in the sphene and pyroxene ijolites represent varieties that occur in small amount. In the common varieties and in the average rock the $\mathrm{TiO}_{2}$ is 1.4 times as high as in the average ijolite and about the same as in the melteigite of the Fen district, Norway.

In the soda syenites the $\mathrm{TiO}_{2}$ is only one-fifth tl a,t in the average of soda syenites, and in the nepheline syenite only six-tenths that of the average nepheline syenite. In the nepheline gabbro it is lower than in the average theralite, and in the quartz gabbro it is somewhat higher than in the average gabbro-diorite.

In general, $\mathrm{TiO}_{2}$ is very high in the pyroxene rook, near the average for the plagioclase, melilite, and nepheline rocks, and very low for the alkali-feldspar rocks.

The titanium is largely present in minerals in which titanium is an essential constituent and the amount of titanium in a rock is dependent chiefly on the proportion of such constituent. $\mathrm{TiO}_{2}$ is low in the pyroxenes of the area, with the possible exception of those 
in the quartz gabbro and nepheline gabbro. In the uncompahgrite and pyroxenite the titanium is chiefly in perofskite, with a little in ilmenite, melanite, biotite, pyroxene, and some other minerals. In the ijolite, much of the titanium is in melanite, some in ilmenite and the mafic minerals, and little in sphene. In the syenite and nepheline syenite the $\mathrm{TiO}_{2}$ is mostly in the ilmenite, sphene and pyroxene. In the nepheline gabbro and quartz gabbro it is in ilmenite and the pyroxenes.

During all stages of the crystallization of the magmas titanium separated into the crystalline phases, but it remained in considerable amount in the last residual liquid and was precipitated in the melanite and continued to be precipitated in the early hydrothermal stage. Sphene was also precipitated in the early hydrothermal stage. In the later hydrothermal stage considerable $\mathrm{TiO}_{2}$ was fixed in the amphiboles and as anatase.

Phosphorus.- Phosphorus is high in amount and rather erratically distributed in both the pyroxenite and the ijolite. In the average pyroxenite from Iron Hill it is 1.3 times as high as in the average alkalic pyroxenite, and much higher than in the similar rocks from Jacupiranga or Hot Springs or than in the average diallagite, but it is only a third as high as in the pyroxenite from Libby, Mont. In the ijolite at Iron Hill the $\mathrm{P}_{2} \mathrm{O}_{5}$ is $1 \frac{11}{2}$ times as high as in the average of the ijolite family and somewhat less than in the melteigite from the Fen district. The $\mathrm{P}_{2} \mathrm{O}_{5}$ in the uncompahgrite, quartz gabbro, and nepheline gabbro is slightly lower than in the average of similar rocks. In the akali feldspar rocks (syenite and nepheline syenite) the $\mathrm{P}_{2} \mathrm{O}_{5}$ is only one-tenth that of the average of such rocks.

The $\mathrm{P}_{2} \mathrm{O}_{5}$ is in the apatite. In the pyroxenite the apatite tends to be associated with the biotite and iron ore and especially with the perofskite. These and the veinlets of nearly pure apatite are late varieties of the pyroxenite.

Apatite is also one of the chief hydrothermal minerals and is present in the marble at Iron Hill, the contact- metamorphic products, and the veins. Some veins are made up chiefly of martite, apatite, and carbonate.

Manganese.-Manganese dioxide amounted to 0.21 percent in the quartz gabbro analyzed and 0.20 percent in the average uncompahgrite. It is rather uniform in the ijolite, regardless of the prevailing dark mineral, and averages 0.18 percent. It is more variable in the different varieties of pyroxenite and averages 0.14 percent. It is high in the iron ores and in the feldspar-nepheline rock. The soda syenite contained 0.13 percent, the nepheline gabbro 0.11 percent, and the nephel:ne syenite 0.07 percent. The average content of the Iron Hill stock is somewhat higher than that of the average igneous rock, but in any of the rock types manganese is near that for the average of the rock family, except in the nepheline syenite, where it is much lower.

The manganese appears to be widely distributed in the minerals of the stock. It is about as abundant in the melilite as in the uncompahgrite. It is especially high in the iron ores and hence in the magnetite and perofskite. The pyroxenes appear to contain even less manganese than the rocks in which they are the dominant mineral. The melanite does not appear to contain any more manganese than the pyroxenes. To account for the high manganese in the ijolites it seems probable that there is appreciable $\mathrm{MnO}$ in the nepheline; otherwise the iron ores must be very high in $\mathrm{MnO}$. Phlogopite contains about the same amount of $\mathrm{MnO}$ as the pyroxene. In the pyroxenes the $\mathrm{MnO}$ increases with the acmite $(\mathrm{Fe})$ molecule.

In the melilite $\mathrm{Mn}$ must have replaced $\mathrm{Ca}$, but there has been no such replacement in the apatite, which in many other localities contains $\mathrm{Mn}$. In the biotite it must have replaced iron. In the other minerals it may have replaced either $\mathrm{Fe}$ or $\mathrm{Ca}$. In the pyroxenes it appears to be highest in the aegirite. In genoral the Mn content shows no simple relation to the cor tent of $\mathrm{Fe}^{\prime \prime}, \mathrm{Fe}^{\prime \prime \prime}$, or $\mathrm{Ca}$ or any other major constituent (table 31). ${ }^{56}$

56 This is not very different from Vernadsky's statement that basic rocks have part $\mathrm{MnO}$ to $100 \mathrm{Fe}$ and acidic rocks $1 \mathrm{MnO}$ to $30 \mathrm{Fe}$. Vernadsky, W. J. (German translation of E. Korde), Geochemie, p. 62, Leipzig, Akad. Verlag, 1930. 
TABLE 31.-Ratios in Iron Hill rocks and minerals

$\left[\frac{\mathrm{BaO}}{\mathrm{CaO}+\mathrm{BaO}} \times 100\right.$ (column 1), $\frac{\mathrm{BaO}}{\mathrm{CaO}+\mathrm{BaO}+\mathrm{K}_{2} \mathrm{O}} \times 100$ (column 2), $\frac{\mathrm{SrO}}{\mathrm{CaO}+\mathrm{SrO}} \times 100\left(\right.$ column 3), $\frac{\mathrm{SrO}}{\mathrm{CaO}+\mathrm{SrO}+\mathrm{K}_{2} \mathrm{O}} \times 100$ (column 4), $\frac{\mathrm{MnO}}{\mathrm{FeO}+\mathrm{MnO}}$ $\times 100($ column 5$), \frac{\mathrm{MnO}}{\mathrm{Fe} O+\mathrm{Fe}_{2} \mathrm{O}_{3}+\mathrm{MnO}} \times 100$ (column 6), and $\frac{\mathrm{BaO}}{\mathrm{SrO}}$ (column 7) $]$

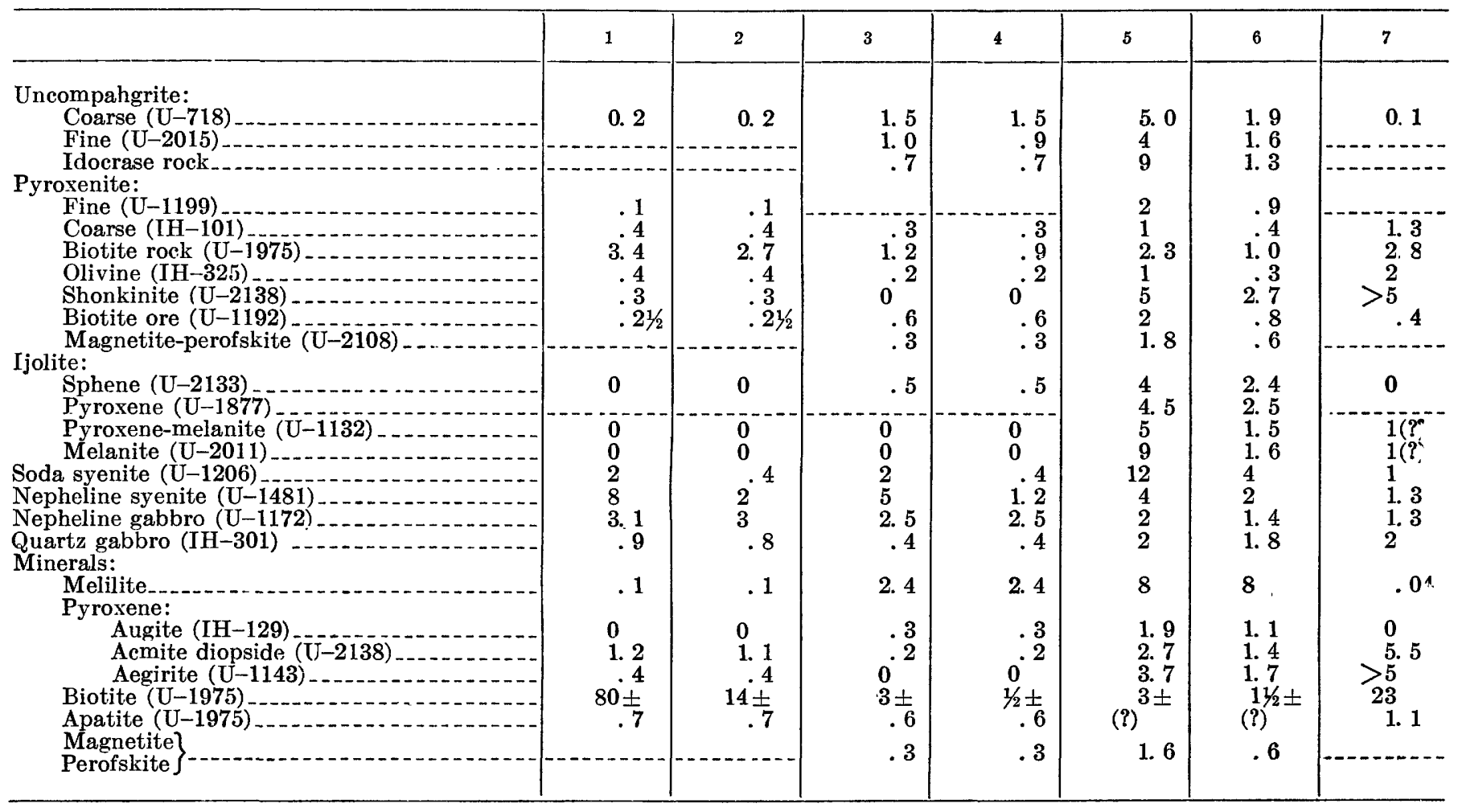

\section{The ratio $\frac{\mathrm{MnO}}{\mathrm{FeO}+\mathrm{Fe}_{2} \mathrm{O}_{3}+\mathrm{MnO}} \times 100$ ranges from 0.3 to}

2.7 in most of the rocks and minerals but is 8.0 for the melilite. It is low in most of the pyroxenite; moderate in the nepheline gabbro, quartz gabbro, uncompahgrite, ijolite, and nepheline syenite; and high in the soda syenite, shonkinite, and some of the altered rocks. Among the minerals, it is low in the magnetite-perofskite mixture, moderate in the biotite, moderate in the pyroxenes but increasing with the acmite molecule, and very high in the melilite.

Barium and strontium. $-\mathrm{BaO}$ and $\mathrm{SrO}$ are very high in the nepheline gabbro and $\mathrm{SrO}$ is high in the uncompahgrite; they are much lower in the pyroxenite except in the biotite-rich types. They are moderate in the nepheline syenite, lower in the quartz gabbro, still lower in the soda syenite and practically absent from the normal ijolites though they are present in the rare sphene variety and in the altered analcime rock.

Comparing the Iron Hill rocks with the average rock of the families to which they belong, ${ }^{57}$ we find that $\mathrm{BaO}$ is $2 \frac{1}{2}$ times as high in the pyroxenite and nepheline gabbro and $1 \frac{1}{2}$ times as high in the quartz gabbro as in the average for their families. It is a little lower in the nepheline syenite, one-third as high in the soda syenite, and less than one-tenth as high in the ijolite.
$\mathrm{SrO}$ is even more extreme, as it is four times as high in the pyroxenite, nepheline gabbro, and uncompahgrite, twice as high in the quartz gabbro, about equal in the syenite and nepheline syenite, and less than one-tenth as high in the ijolite.

The amounts of $\mathrm{BaO}$ and $\mathrm{SrO}$ in the chief minerals of the area have been determined in some specimens and estimated from the rock analyses in others and are listed in table 30. The pyroxenes are moderate to low in $\mathrm{SrO}$ and low in $\mathrm{BaO}$. The melilite is very high in $\mathrm{SrO}$ and low in $\mathrm{BaO}$. The biotite is very high in $\mathrm{BaO}$ and low in SrO. The olivine, nepheline, melanite, magnetite, perofskite, and alkali feldspar appear to be low in both oxides. The plagioclase is uncertain, as both oxides are high in the nepheline gabbro and rathor low in the quartz gabbro. The apatite is high in both $\mathrm{BaO}$ and $\mathrm{SrO}$. The $\mathrm{SrO}$ content of the Iron Hill minerals falls within the range found by Noll ${ }^{58}$ but is much higher in the apatite than in most igneous apatites and lower than in some hydrothermal apatites.

In the Iron Hill area the $\mathrm{Sr}$ appears to be chiefly in minerals rich in $\mathrm{Ca}$ and low in $\mathrm{Fe}$ and $\mathrm{Mg}$. It is low in the potash minerals.

The $\mathrm{Ba}$ is high only in the biotite, apatite, and porsibly in the plagioclase of the nepheline gabbro. In t]? biotite it has probably replaced $K$; in the apatite ard plagioclase it has replaced Ca.

67 Tröger, E., op. cit. (Chemie der Erde, Band 9), pp. 305-307.

68 Noll, W., op. cit. (Chemie der Erde, Band 8), p. 547. 
In the Iron Hill area no barium or strontium minerals were found in the hydrothermal products. $\mathrm{Ba}$ and $\mathrm{Sr}$ are about the same in amount in the hydrothermal amphiboles as in the igneous pyroxenes. At Libby, Mont., in a similar petrographic province, celestite and strontianite are present in the high-temperature veins associated with amphibole, vandiferous aegirite, chalcopyrite, and quartz.

In table 31 are shown for the rocks and minerals of Iron $\mathrm{Hill}$ the ratios of $\mathrm{BaO}$ and $\mathrm{SrO}$ to $\mathrm{CaO}+\mathrm{BaO}$ (or $\mathrm{SrO}$ ) and to $\mathrm{CaO}+\mathrm{K}_{2} \mathrm{O}+\mathrm{BaO}$ (or $\mathrm{SrO}$ ), of $\mathrm{MnO}$ to $\mathrm{FeO}+\mathrm{MnO}$ and to $\mathrm{FeO}+\mathrm{Fe}_{2} \mathrm{O}_{3}+\mathrm{MnO}$ and of $\mathrm{BaO}$ to SrO. In interpreting these ratios it must be borne in mind that they are not very accurate nor always reliable, as a small error in the determination of these minor oxides may make a large error in the ratios, and this is especially true where the amount of the oxide is small.

None of the groups of ratios are very uniform. Those using $\mathrm{K}_{2} \mathrm{O}$ as well as $\mathrm{CaO}$ in the denominator give slightly greater uniformity for $\mathrm{BaO}$ and $\mathrm{SrO}$ than when $\mathrm{CaO}$ alone is in the denominator, indicating that these oxides have replaced both $\mathrm{CaO}$ and $\mathrm{K}_{2} \mathrm{O}$.

The ratio $\frac{\mathrm{BaO}}{\mathrm{CaO}+\mathrm{K}_{2} \mathrm{O}+\mathrm{BaO}} \times 100$ is near 0 for the ijolites, low in most of the pyroxenites, uncompahgrite, and soda syenite, moderate in the quartz gabbro, and high in the biotite-apatite rock, the nepheline syenite, and the nepheline gabbro. Much the same can be said for the ratio $\frac{\mathrm{SrO}}{\mathrm{CaO}+\mathrm{K}_{2} \mathrm{O}+\mathrm{SrO}} \times 100$, except that it is low in the quartz gabbro, only moderate in the nepheline syenite and biotite-apatite rock, and high in the uncompahgrite.

The ratio $\frac{\mathrm{BaO}}{\mathrm{CaO}+\mathrm{K}_{2} \mathrm{O}+\mathrm{BaO}} \times 100$ is very low for melilite and augite. For the pyroxenes this ratio increases rapidly as the pyroxene approaches aegirite. The ratio for the biotite is extremely high, and that for apatite moderate. The ratio $\frac{\mathrm{SrO}}{\mathrm{CaO}+\mathrm{K}_{2} \mathrm{O}+\mathrm{SrO}} \times 100$ is very high in the melilite, high in the biotite and apatite, and low in the pyroxemes and ore.

Noll found that $\mathrm{SrO}$ goes with $\mathrm{CaO}$ and with $\mathrm{K}_{2} \mathrm{O}$. $\mathrm{He}$ found that the ratio $\frac{\mathrm{SrO}}{\mathrm{CaO}+\mathrm{SrO}} \times 100$ is great in potash feldspar (5 to 50 ), less in plagioclase (0.05 to 0.5 ), still less in augite (0.02 to 0.3$)$ and biotite $(0.05$ to 0.5$)$, and commonly very low in apatite $(0.02$ to 0.9$)$. He concluded: "Das Verhältnis $\mathrm{Sr}$ : Ca nimmt zu von den magmatischen Erstkristallisationen nach den Restkristallisationen hin, etwa in der Reihe Apatit<Augit, Hornblend, Biotit $<$ Plagioklas $<$ Kalifeldspat, Leucit." ${ }^{59}$

In the Iron Hill minerals the ratio for biotite is much above the range given by Noll, and the pyroxenes and

60 Noll, W., op. cit., p. 582. apatite are in his bigher range. For the Iron Fill area the order would seem to be perofskite, magnetite, pyroxene < apatite< biotite and melilite.

It is worth noticing that in the mica-apatite rock ( $\mathrm{SrO}$ and $\mathrm{BaO}$ determination on the apatite and biotite, table 30 ) the $\mathrm{SrO}$ went chiefly to the apatite and the $\mathrm{BaO}$ more to the biotite.

The ratio $\frac{\mathrm{BaO}}{\mathrm{SrO}}$ is between 1 and 2 for most of the rocks, but for the uncompahgrite, the biotite ore, and the sphene ijolite it is very low, and for the biotiteapatite rock it is very high. For the average rock of the Iron Hill stock it is about 1.4. In the aversge igneous rock, according to Clarke and Washingtc ${ }^{60}{ }^{60}$ this ratio is about 2, and according to Tröger ${ }^{61}$ it is 1.7 . For the minerals this ratio is highly variabls. It is very low in the melilite and augite but high in the aegirite and extreme in the biotite.

Zirconium, nickel, chromium, and vanadium.-Zirconium has been determined in only a few of the rocks, and in these it appears to be rather low. Thi is confirmed by the rare occurrence of zircon or other zirconium minerals.

Chromium is practically lacking in all the rocks, in spite of their common ultramafic character. Among the minerals it is found in the biotite ( 0.01 percent) but is lacking in the melanite, sphene, magnetite, and perofskite. Vanadium is present in moderste and rather uniform amounts in the pyroxene, melanite, phlogopite, and magnetite-perofskite. It is much lower in the Iron Hill rocks than in the similar rocks from Libby, Mont.

Chlorine and fluorine.-Chlorine and fluorine are probably about average for such rocks. Fluorine is mostly in the abundant fluorapatite; it is absent from the analyzed biotite.

Fluorine is high in the hydrothermal anphiboles that are abundant in the area and must be present in the hydrothermal micas and apatite. Some fluorite veins are present. Chlorine occurs in small amount in the biotite.

Bearing on petrogenesis.-The content of $\mathrm{TiO}_{2}$, $\mathrm{P}_{2} \mathrm{O}_{5}, \mathrm{BaO}$, and $\mathrm{SrO}$ in the pyroxenite at Iron Hill is much higher than would be expected if this rock originated as postulated in this paper. This is true for the similar rock from Magnet Cove, and it is true for $\mathrm{TiO}_{2}$ in the rock from Jacupiranga and for $\mathrm{P}_{2} \mathrm{O}_{5}$ in the rock from Libby. However, the erratic distribution of these oxides and their marked tendency to concentrate into local parts, commonly with intrusive relations to the impoverished parts, shows that these constituents were highly concentrated in som 9 of the differentiates of the magma, and they may have been concentrated in the outcropping rocks. On the other

$\infty$ Clarke, F. W., and Washington, H. S., op. cit. U. S. Geol. Surver Prof. Paper $12 \overline{7})$, p. 16.

61 Tröger, E. op. cit. (Chemie der Erde, Band 9), p. 307. 
hand, the original magma may have been unusually rich in these constituents.

It is noteworthy that only in the first three intrusives are the $\mathrm{TiO}_{2}$ and $\mathrm{P}_{2} \mathrm{O}_{5}$ constituents unusually high. Indeed, in the later rocks they tend to be lower than in the average rock of similar composition.

Spectroscopic tests.-Spectroscopic tests were made by George Steiger on nearly all the rocks analyzed and on some of the separated minerals as follows:

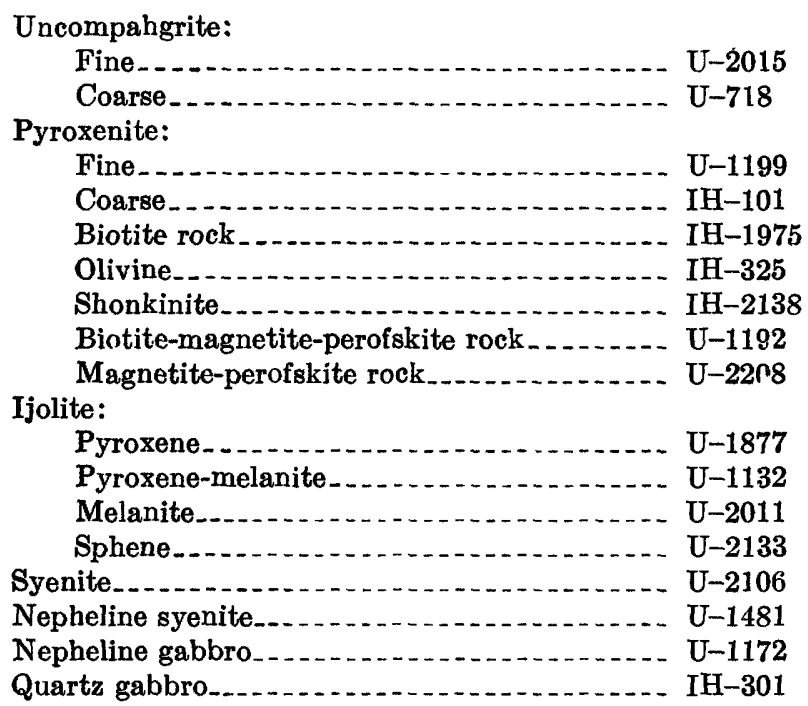

Pyroxene . . . . . . .

Pyroxene-melanite........ U-1132

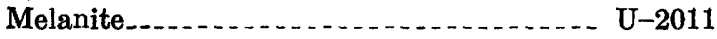

Sphene........... . . . . .

Syenite_..

Nepheline syenite............ U-1481

Nepheline gabbro $\ldots \ldots \ldots$ U-1172

Quartz gabbro.................. IH-301

U-1671, U-2197. Uncompahgrite altered to idocrase-diopside rock.

U-2107. Ijolite, south fork of North Beaver Creek just east of gulley I. Nepheline and pyroxene separated from U-2107.

IH-129, IH-130, IH-132, U-2033. Ijolites of various typer. U-1975. Apatite from biotite-apatite rock (of pyroxenite). U-1975. Biotite from biotite-apatite rock.

U-2033. Garnet from ijolite. Between forks of Beaver Creek, just above alluvium, and near center of body south of mouth of gully $\mathrm{H}$.

The tests were made by placing the powdered ma.terial directly in the graphite electrode without previous chemical separation or concentration, they should datect quantities down to one or two hundredths of $1 \mathrm{p}$ ?r cent, but will not show quantities in the thousandths of 1 percent. Each sample was tested for $\mathrm{Ag}, \mathrm{As}, \mathrm{B}, \mathrm{Be}$, $\mathrm{Bi}, \mathrm{Cd}, \mathrm{Ge}, \mathrm{Sb}, \mathrm{Sn}, \mathrm{Zn}$, and $\mathrm{Pb}$.

Beryllium was found in all the uncompahgrites testel, including the altered upcompahgrite (idocrase-diopside rock), in one (U-2107) out of eight ijolites, in the pyroxene from that ijolite, and a doutbful test from the ne?heline of that rock. The tests on all the specimens were negative for all the other metals listed.

Mr. E. K. Gedney informs us that a sample of the uncompahgrite altered to idocrase and diopside from the Iron Hill area tested by him carried 0.28 percent of $\mathrm{BeO}$ and 0.6 percent of gallium and indium. 


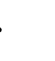




\section{IN DEX}

Page

Abstract

Accessibility of the area

Acknowledgments for aid.

Acmite diopside, minor constituents in

Aegirite, character and occurrence of

Albite, character and occurrence of

Alno stock, features of

Amphiboles, character and occurrence of

Analcime, character and occurrence of

Anatase, occurrence of

A patite, character and occurrence of

Assynt laccolith, features of

Augite, minor constituents of.

Augite syenite, analysis and norm of

character and distribution of

Barium, occurrence of

Beryllium, occurrence of

Billings, Marland, optical data by
Biotite, character and occurrence of

Biotite ijolite, analysis of

24

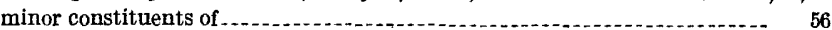
spectroscopic tests of

Biotite ore, minor constituents of

Biotite rock, analysis, norm, and mode of..................................... 22 minor constituents of occurrence of . . . spectroscopic tests of Brugnatellite, occurrence of

$7,15-16,23,44$

Calcite, occurrence of.-

$33,54-55$

Carbonate deposits, character and distribution of $5,6,7,31,32,44$, pl. 1

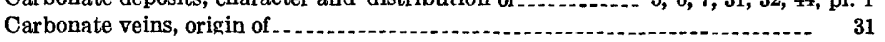

Cebollite, analyses of .

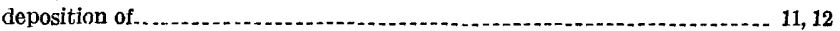

Chalcopyrite, occurrence of

Chalcopyrite, occurrence of
Chemistry of the stock.
Chibina Tundra bysmalith, features of

Chibina Tundra bysmalith, features of
Chlorine, occurrence of

Chlorite, occurrence of

Chromium, occurrence of

Cromaltite, analysis, norm, and mode of

Dikes, character and occurrence of ............................ 28, 29-30

Diopside, deposition of . .............. 11-12

occurrence of . . . .

Dolomite, occurrence of

Essexite, minor constituents of

Feldspar, occurrence of

Feldspar-bearing pyroxenite, character and distribution of

spar-nepheline pyroxenite, analysis, norm, and mode of .............. 20,21, 22 character and distribution of

Fen district, rocks of

Field work
Fluorine, occurrence of

$\begin{array}{ll}\text { Fluorite, character and occurrence of } & 43 \\ \text { Foshag, W. F., analysis by } & \end{array}$

Gabbro, analyses, norms, and modes of
character and distribution of $\ldots \ldots \ldots \ldots . . .12-13,29,36$ character and distribution of
origin of $\ldots . . . . . . . .42$ spectroscopic tests of.

Galena, occurrence of

Gallium, occurrence of

Garnet, character and occurrence of deposition of.

Garnet pyroxenite, character and distribution of

Gemmell, A., analyses by

Geology of the Iron Hill area

Glaucophane, character and occurrence of
1-2

Gonyer, F A, analyses by Gunnisonite, occurrence of $\ldots . \ldots \ldots \ldots$

Hastingsite, occurrence of

Hematite, occurrence of

Herdsman, W. H., analyses by........... 46

Hydrothermal deposits, character and deposition of chemistry of .

comparison of, with other areas. ................................................ 34

Ice River laccolith and stock, features or.

Idocrase, character and occurrence of

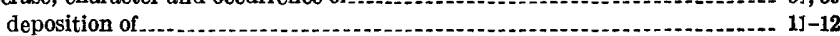

Idocrase-diopside rock, minor constituents of ................................. 56

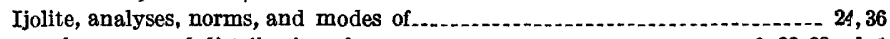
character and distribution of ....................................... 3, 22-23, $\mathrm{f} 1.1$ crystallization of

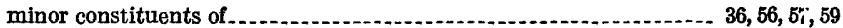

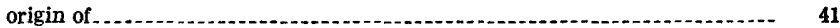

spectroscopic tests of

Imperial Chemical Institute, England, analysis by . . . .

Indium, occurrence of

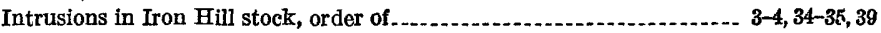

Intrusive bodies, features of . .

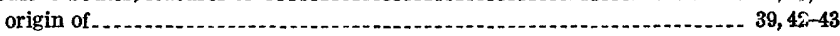

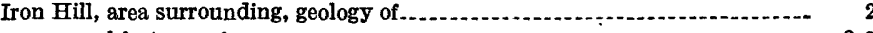

general features of

marble of, age of ..................

character and distribution of

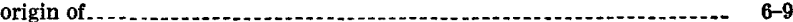

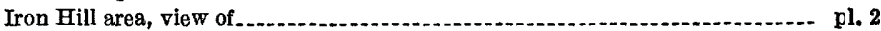

Iron Hill stock, age of

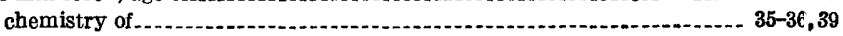

comparison of, with similar masses.......................................... $36-43$

formations in, relative size of

general geology of .

intrusions in, order of

minerals of ....... $35,38-39,43-56$

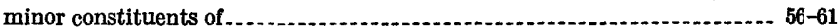

origin of

special features of

tron ore, origin of .

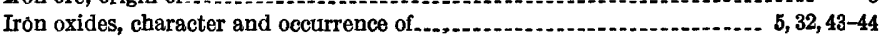

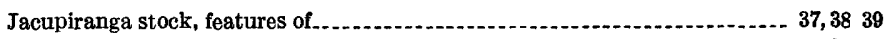

Jacupirangite, analysis, norm, and mode of .................................. 2022

Juanite, character of .

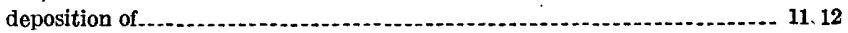

Jurassic rocks, occurrence of $\ldots$

Laudermilk, J. D., analysis by

Libby stock, features of

Lime-soda feldspar, occurrence of

Limonite, occurrence of

Location of the area

Maclaurin, J. S., analyses by

Magnet Cove stock, features of ............. 38,39

Magnetite, occurrence of See also Biotite-magnetite-perofskite rock.

Magnetite-perofskite rock, analysis, norm, and mode of-................ 20, 21.22 character and occurrence of . . spectroscopic tests of

Manganese, occurrence of ......................... 56-57, 58-59

Marble, character and distribution of

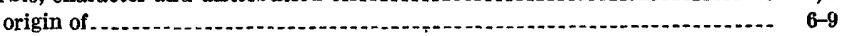

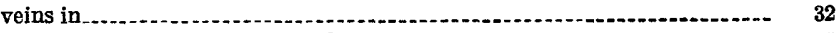

Martite-apatite veins, character and occurrence of .............................. 5

Melanite, character and occurrence of ....... 33, 54, 5659 spectroscopic tests of

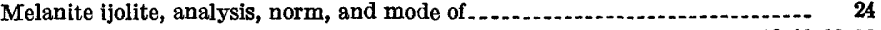

Melilite, alterations of ............ 10, 11, 12,33 character and occurrence of

Melilitholite, minor constituents of... 
Melteigite. See Ijolite; Nepheline pyroxenite.

Micas, character and occurrence of.

Microcline, character and occurrence of -.

Minerals, character and distribution of . ............. 35, 38-39, 43-60 deposition of ................... 4, 31-33 See also names of minerals.

Minor constituents, bearing of, on petrogenesis occurrence of, in rocks and minerals

Morrison formation, occurrence of...

Mount Dromedary laccolith, features of. $60-61$

Muscovite, occurrence of

2, pl. 1 $37,38,39$

Natrolite, character of See also Feldspar-nepheline pyroxenite; Sphene-nepheline pyroxenite.

Nepheline gabbro, analysis, norm, and mode of character and distribution of

29,36 origin of. $4,28,56,57,59, \mathrm{pl} .1$ spectroscopic tests of.

Nepheline pyroxenite, analysis, norm, and mode of character and distribution of 16

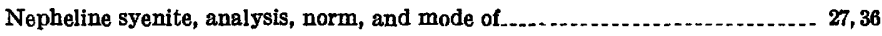
character and distribution of........... 1 origin of ...

spectroscopic tests of

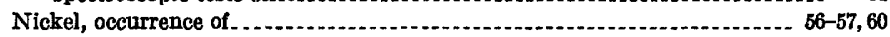

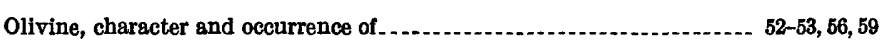
spectroscopic tests of

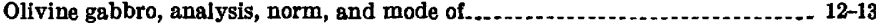
character and occurrence of.............................................. 30

Olivine pyroxenite, analysis, norm, and mode of

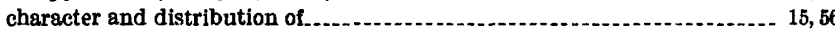

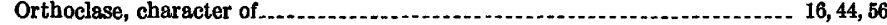

Paleozoic rocks, occurrence of

Parker, S., analysis by - .

Perofskite, character and occurrence of See also Biotite-magnetite-perofskite rock; Magnetite-perofskite rock.

Phlogopite, character and occurrence of

Phosphorus, occurence and occh

Plagioclase, minor constituents of

作 1

Pre-Cambrian rocks, character and occurrence of................. 2, 5, 7, 29-30, pl. 1 geologic history of

Pyrite, occurrence of.

Pyroxene, character and occurrence of $. . . . . .45,56,59$ spectroscopic test of

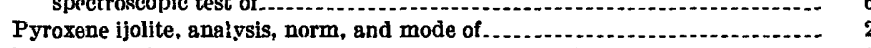

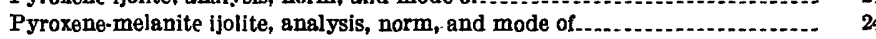

minor constitnents of .

spectroscopic test of

Pyroxenite, age of . anaiyses, norms, and modes of character and distribution of ................. 3, 13, 14-18, 56, 57, 69, pls. 1, 3 origin of -

$19-20,40-4$ spectroscopic tests of
DEX

Page

Quartz gabbro, analyses, norm, and modes of character and distribution of origin of ................ 49 spectroscopic test of

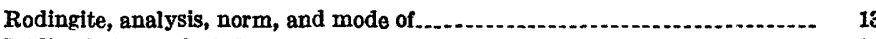

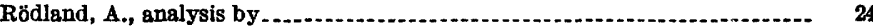

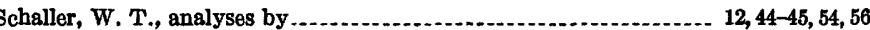

Sekukuniland stock, features of...........

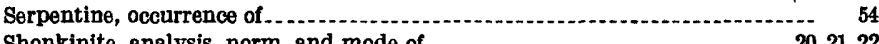

Shonkinite, analysis, norm, and mode of $\ldots$ character and distribution of......................................... 16, 30, 56, 59

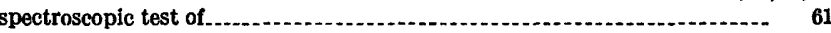

Silicates, character and occurrence of ...................... 5 -6 origin of

Soda syenite, analyses, norm, and modes of .................................... 26, 36 character and distribution of .......... Soda tremolite, character and occurrence of ................................ 50-52

Sphalerite, occurrence of

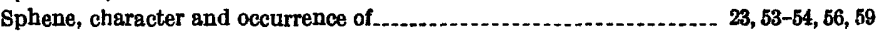

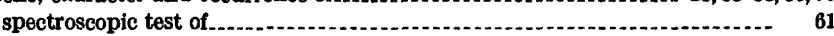
Sphene-nepheline pyroxenite, analyses, norms, and modes of........... 20,21, 22, 24 Sphene pyroxenite, character and distribntion of

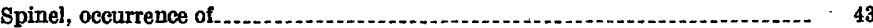

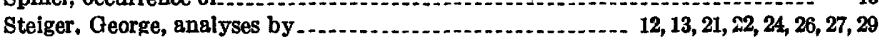
spectroscopic tests by

Strontium, occurrence of

Sulfatic cancrinite, occurrence of

Sulfides, occurrence of ................. 43

Syenite, character and distribution of

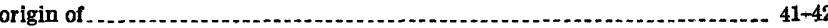

spectroscopic test of

See also Augite syenite; Nepheline syenite; Soda syenite.

Theralite, minor constituents of

Titanium, character and occurrence of ................................. 43, 56, 57-58

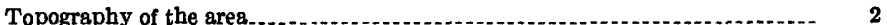

Turja area, rocks of

Turjaite, analysis, norm, and mode of minor constituents of

Uncompahgrite, analyses, norms, and modes of ............................. 12-13, 36 alteration of character and distribution of origin of .................. 40

spectroscopic tests of

Vanadium, occurrence of Veins. character and occurrence of ......................................... 5, 31, 32

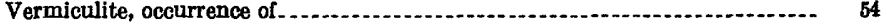

Wahlstrom, E. E., analysis by

Washington, H. S.. analyses by

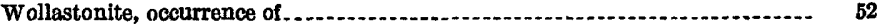

Zeolite, character and occurrence of

Zirconium, character and occurrence of ........... 
The use of the subjoined mailing label to ret urn this report will be official business, and no postage stamps will be required

UNITED STATES DEPARTMENT OF THE INTERIOR GEOLOGICAL SURVEY

OFFICIAL BUSINESS

This label can be used only for returning official publications. The address must not be changed.
PENALTY FOR PRIVATE USE TO AVOID PAYMENT OF POSTAGE, $\$ 300$

\section{GEOLOGICAL SURVEY,}

